UNIVERSIDADE DE SÃO PAULO

FACULDADE DE ECONOMIA, ADMINISTRAÇÃO E CONTABILIDADE DEPARTAMENTO DE ADMINISTRAÇÃO

PROGRAMA DE PÓS-GRADUAÇÃO EM ADMINISTRAÇÃo

O DESAFIO DE GESTÃO DA MUDANÇA EM COMBINAÇÕES EMPRESARIAIS: A INDÚSTRIA DE CIÊNCIAS DA VIDA

Guilherme Rhinow

Orientadora: Profa. Dra. Rosa Maria Fischer

SÃO PAULO

2006 
Prof. Dr. Adolpho José Melfi

Reitor da Universidade de São Paulo

Profa. Dra. Maria Tereza Leme Fleury

Diretora da Faculdade de Economia, Administração e Contabilidade

Prof. Dr. Eduardo Pinheiro Gondim de Vasconcellos

Chefe do Departamento de Administração

Prof. Dr. Isak Kruglianskas

Coordenador do Programa de Pós-Graduação em Administração 
GUILHERME RHINOW

\title{
O DESAFIO DE GESTÃO DA MUDANÇA EM COMBINAÇÕES EMPRESARIAIS: A INDÚSTRIA DE CIÊNCIAS DA VIDA
}

\author{
Tese apresentada ao Departamento de \\ Administração da Faculdade de Economia, \\ Administração e Contabilidade da \\ Universidade de São Paulo como requisito \\ para a obtenção do título de Doutor em \\ Administração de Empresas.
}

Orientadora: Profa. Dra. Rosa Maria Fischer

SÃO PAULO 
Rhinow, Guilherme

O desafio de gestão da mudança em combinações empresariais : a indústria de ciências da vida / Guilherme Rhinow. - São Paulo, 2006.

$187 \mathrm{p}$.

Tese (Doutorado) - Universidade de São Paulo, 2006

Bibliografia

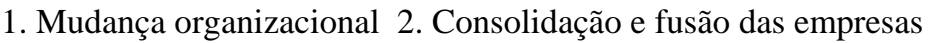
I. Universidade de São Paulo. Faculdade de Economia, Administração e Contabilidade II. Título. 
Aos queridos André, Gabriel e Dani que, comigo, fazem uma harmoniosa combinação. 


\section{AGRADECIMENTOS}

Várias pessoas atuaram, direta ou indiretamente, no processo de elaboração desta tese. A todas elas dirijo os meus agradecimentos.

Os professores da Faculdade de Economia, Administração e Contabilidade da Universidade de São Paulo desempenharam relevante papel para o meu desenvolvimento acadêmico ao longo do programa de doutorado. Destaco a relevante atuação de Marisa Eboli, André Fischer, Tânia Casado, Paulo Feldmann e Abraham Yiu. Na Fundação Getúlio Vargas, saliento o rico contato com Francisco Aranha e Maria José Tonelli. Foi importante também a atuação dos professores Paul Evans e Dominique Héau durante a minha rápida passagem pelo Insead para a definição do enfoque internacional deste trabalho.

Três professores tiveram participação fundamental na elaboração e delimitação do tema de pesquisa. Maria Tereza Fleury lançou o desafio de elaborar uma disciplina sobre aquisições e fusões para o programa MBA Recursos Humanos da Fundação Instituto de Administração, lançando as primeiras sementes para a futura elaboração da tese. Moises Sznifer propôs a elaboração de um artigo, o qual tornou-se o fundamento teórico desta aula no programa de MBA. Por fim, Joel Dutra acompanhou o aprimoramento das aulas com o seu permanente estímulo às atividades de pesquisa e docência.

A professora Rosa Maria Fischer, orientadora, companheira e conselheira sempre presente, participou ativamente de toda esta trajetória. Sua contribuição foi significativa para a tomada de decisões acadêmicas assim como profissionais e pessoais tais como a mudança com a família para a Europa. Os intensos momentos de criação e aprendizado compartilhados com ela desde o mestrado e os ensinamentos recebidos nos inúmeros projetos de consultoria e pesquisa realizados em conjunto estão presentes no conteúdo das páginas a seguir.

Os familiares Leda e Kurt, com seu constante estímulo e apoio, criaram mais uma vez um "porto seguro“ para os meus saltos profissionais e acadêmicos. Outra pessoa bastante presente foi Ângela Mandari, com o seu suporte de valor inestimável desde o início do programa de doutorado. 
A Dani, com seu amor incondicional, companheirismo, carinho e compreensão, trouxe a energia necessária para viabilização desta tese. Além disso, ela novamente mergulhou na teoria organizacional e trouxe o seu talento literário para aprimorar o conteúdo gerado. O André e o Gabriel, mesmo chegando em momentos diferentes do processo, participaram ativamente da elaboração e conclusão deste trabalho, atuando sempre como fonte de inspiração para a minha dedicação ao trabalho e à pesquisa. 


\section{RESUMO}

Os desafios de competitividade têm levado as organizações a estruturarem estratégias robustas de crescimento, consolidando a sua atuação em determinados setores ou mesmo levando à expansão das suas atividades para novos mercados e regiões geográficas. As combinações empresariais, caracterizadas por aquisições e fusões, tornam-se cada vez mais relevantes para a viabilização destas estratégias e passam a fazer parte integrante da agenda dos líderes empresariais. Diante dos baixos indicadores de efetividade verificados em operações desta natureza, torna-se importante refletir sobre a sua gestão e identificar as condições necessárias para que as novas configurações organizacionais implementadas resultem alinhadas às orientações estratégicas que motivaram a realização destas transações.

Este trabalho insere-se neste tema ao propor um modelo de gestão da mudança organizacional advinda de combinações empresariais e a sua aplicação no setor de ciências da vida. As oportunidades características deste novo setor, com fronteiras ainda pouco estabelecidas, têm gerado uma série de movimentos de combinação em empresas tradicionais do setor químico, em busca de crescimento ou obtenção de indicadores mais elevados de competitividade.

Ao propor o modelo de gestão, este trabalho traz duas contribuições para o arcabouço conceitual sobre aquisições e fusões. Em primeiro lugar ele elabora, com base no referencial teórico disponível, um conjunto de categorias para a gestão da etapa de integração entre as empresas participantes de um processo de combinação. A aplicação deste conhecimento na realidade empírica, com adoção de procedimentos estatísticos, levou à identificação de uma nova categoria - denominada clareza de expectativas - que está relacionada ao estabelecimento de relações entre a empresa e os seus profissionais visando fortalecer a adesão e o comprometimento das pessoas com os novos modelos de gestão implementados. A segunda contribuição corresponde à verificação da importância de não dissociar a etapa de integração das empresas do processo decisório que levou à efetivação destas transações. A atenção antecipada às variáveis indicadas neste trabalho, para o momento anterior ao fechamento do acordo de combinação, pode evitar equívocos e conflitos viabilizando uma integração efetiva entre as organizações participantes da operação. 


\begin{abstract}
The challenges around competitiveness faced by organizations are leading them to structure robust growth strategies, consolidating their presence in specific economic sectors as well as ensuring their growth in new markets and geographic regions. The combination of companies, identified as mergers and acquisitions, are gradually becoming more important to enable the implementation of these strategies and therefore constitute important components of leaders agenda. It is a key challenge to reflect about the managerial aspects of these transactions due to the low effectiveness indicators identified, researching the required conditions that will enable the alignment between the new organizational configurations and the strategic drivers that motivated their implementation.
\end{abstract}

This study is related to this theme since it proposes a model to manage organizational change that results from this type of transaction. The model is also applied in combinations within the life sciences sector. The potential opportunities identified in this new sector, which has low defined boundaries, have generated some combinations between traditional chemical companies aiming at growing or reaching higher levels of competitiveness.

Whilst proposing the management model, this thesis builds two contributions to the conceptual framework around mergers and acquisitions. It designs, as a result of the available theoretical references, one set of categories to manage the integration phase for companies facing combination processes. The application of this knowledge in an empirical reality, enabled by statistical procedures, led to a new category identificaion - named as clarity of expectation - which refers to the relationship established by the company and its employees and aims to reinforce the people commitment with the new management models implemented. The second contribution shows the importance to connect the integration planning phase to the decision making process that leads into the transaction. The anticipated analysis of the variables presented by this thesis in the previous stage before the deal conclusion can mitigate mistakes and conflicts enabling an effective integration between the companies that are part of these operations. 


\section{SUMÁRIO}

PARTE 1: INTRODUÇÃO

Apresentação do tema

Colocação do problema de pesquisa $\quad 3$

PARTE II: REFERENCIAL TEÓRICO

$\begin{array}{ll}\text { Introdução } & 7\end{array}$

CAPÍTULO 1: CONCEITO E EVOLUÇÃO DAS COMBINAÇÕES ENTRE $\begin{array}{ll}\text { EMPRESAS } & 8\end{array}$

$\begin{array}{ll}1.1 \text { Histórico } & 8\end{array}$

$\begin{array}{ll}\text { 1.2 Magnitude destas operações no momento atual } & 11\end{array}$

$\begin{array}{ll}1.3 \text { Colocação da questão no Brasil } & 15\end{array}$

$\begin{array}{ll}1.4 \text { Razões que levam às combinações entre empresas } & 16\end{array}$

$\begin{array}{lr}1.5 \text { Principais tipos de combinações } & 18\end{array}$

1.6 Estratégia em operações de combinações empresariais

1.6.1 Integração horizontal $\quad 27$

$\begin{array}{ll}\text { 1.6.2 Expansão } & 28\end{array}$

1.6.3 Integração vertical 31

1.6.4 Redefinição de fronteiras na indústria 32

1.7 Análise da efetividade destas operações no momento atual 33

1.8 Etapas do processo de combinação entre empresas

1.9 Causas de fracasso das operações de combinação empresarial 41

CAPÍTULO 2: A MUDANÇA ORGANIZACIONAL COMO DESAFIO DE GESTÃO $\quad 46$

2.1 Evolução do conceito de mudança $\quad 46$

2.2 Uma nova concepção: o processo de mudança 48

2.30 desafio de gestão dos processos de mudança

CAPÍTULO 3: GESTÃO DA MUDANÇA NAS COMBINAÇÕES
EMPRESARIAIS

PARTE III: PESQUISA EMPÍRICA

$\begin{array}{ll}\text { Introdução } & 67\end{array}$ 
$\begin{array}{lr}\text { 4.1 Definições gerais } & 68\end{array}$

4.2 Detalhamento técnico do levantamento e análise de dados $\quad 74$

4.2.1 Etapa 1: Formação e desenvolvimento do conceito de ciências da vida $\quad 74$

$\begin{array}{ll}\text { 4.2.2 Etapa 2: Estudo de caso } & 75\end{array}$

\section{CAPÍTULO 5 - EVOLUÇÃO DA INDÚSTRIA QUÍMICA E A EMERGÊNCIA DAS} CIÊNCIAS DA VIDA

5.1 Histórico

5.2 Ciências da vida: um setor industrial em construção

CAPÍTULO 6 - O ESTUDO DE CASO DO PROCESSO DE COMBINAÇÃO EMPRESARIAL

6.1 Informações gerais sobre a empresa

6.2 Análise do material levantado nas entrevistas $\quad 101$

$\begin{array}{ll}\text { 6.2.1 Planejamento estratégico } & 101\end{array}$

$\begin{array}{lr}\text { 6.2.2 Prospeç̧ão de oportunidades } & 102\end{array}$

6.2.3 Avaliação de oportunidades 103

6.2.4 Negociação e execução do acordo 106

$\begin{array}{ll}\text { 6.2.5 Integração pós-combinação } & 107\end{array}$

6.2.6 Elementos comuns das diversas etapas 109

6.3 Análise dos dados obtidos nos questionários $\quad 110$

6.3.1 Apresentação dos resultados gerais 111

6.3.2 Resultados da análise fatorial 112

$\begin{array}{ll}\text { 6.3.3 Resultados da análise de consistência } & 120\end{array}$

6.4 Análise da integração pós-combinação 122

$\begin{array}{lr}\text { 6.4.1 Visão de futuro } & 125\end{array}$

6.4.2 Comunicação 126

6.4.3 Processo de integração 127

6.4.4 Gestão de recursos humanos 128

$\begin{array}{ll}\text { 6.4.5 Clareza de expectativas } & 129\end{array}$

PARTE IV: CONSIDERAÇÕES FINAIS 141

APÊNDICE A: LINHA DO TEMPO DAS EMPRESAS QUÍMICAS QUE PASSARAM A ATUAR EM CIÊNCIAS DA VIDA

APÊNDICE B: ROTEIRO DAS ENTREVISTAS SEMI-ESTRUTURADAS APLICADO JUNTO AOS PROFISSIONAIS DA EMPRESA

APÊNDICE C1: MODELO DO QUESTIONÁRIO: VERSÃO ORIGINAL EM INGLÊS 
APÊNDICE C2: MODELO DO QUESTIONÁRIO: VERSÃO TRADUZIDA PARA O PORTUGUÊS

APÊNDICE D: DADOS DA ANÁLISE DE CONSISTÊNCIA

APÊNDICE E: RESULTADOS DA ANÁLISE FATORIAL

PARTE V: REFERÊNCIAS BIBLIOGRÁFICAS 


\section{LISTA DE GRÁFICOS}

Gráfico 1: As maiores fusões dos EUA (US\$ bilhões)

Gráfico 2: Evolução das aquisições e fusões entre 2002 e 2004: volume financeiro

Gráfico 3: Evolução das aquisições e fusões entre 2002 e 2004: número de acordos

Gráfico 4: Razões estratégicas para a realização de aquisições e fusões

Gráfico 5: Resultados da pesquisa conduzida pela A. T. Kearney

Gráfico 6: Procedência dos profissionais que compõem a população pesquisada

Gráfico 7: Alocação dos respondentes

\section{LISTA DE QUADROS}

Quadro 1: Tipos de combinações entre empresas

Quadro 2: Detalhamento da síndrome das combinações

Quadro 3: Abordagem contextualista da mudança

Quadro 4: Aquisições e fusões na indústria farmacêutica

Quadro 5: Estrutura de grupos implementada nas transações analisadas

\section{LISTA DE TABELAS}

Tabela 1: Proposição de categorias de estratégias para as combinações

Tabela 2: Primeira versão do modelo de gestão da mudança para combinações empresariais

Tabela 3: Exemplo de resultado em uma aquisição: antes e depois

Tabela 4: Modelo de gestão da mudança com detalhamento da etapa de integração póscombinação 
Tabela 6: Composição do grupo de profissionais entrevistados

Tabela 7: Evolução das categorias propostas para a etapa de integração pós-combinação120

Tabela 8: Coeficientes de confiabilidade para as categorias propostas

Tabela 9: Proposta de exclusão de variáveis das categorias

Tabela 10: Questões e análise de consistência para as categorias da etapa de integração póscombinação

Tabela 12: Aplicação do modelo de gestão da mudança no estudo de caso em profundidade

Tabela 13: Detalhamento da abordagem de gestão da mudança implementada na etapa de integração pós-combinação 


\section{PARTE I: INTRODUÇÃO}

\section{Apresentação do tema}

A intensidade e a volatilidade das pressões ambientais presentes no momento atual têm imposto para as empresas desafios bastante complexos. Os conceitos de globalização, competitividade, lucratividade e mudança fazem parte integrante das agendas das lideranças empresariais, que estão voltadas para a identificação de elementos e práticas de gestão com o intuito de garantir a sobrevivência, o crescimento e a prosperidade das suas organizações.

A necessidade de crescimento no ambiente global, através da ampliação da atuação em novos territórios geográficos, complementação do portfolio de produtos e serviços ou mesmo aproveitamento de novas oportunidades na indústria, tem levado a um aumento significativo de combinações entre empresas, caracterizadas por operações de aquisições e fusões. Esta tendência vem remodelando relações entre diferentes organizações e reconfigurando cadeias de negócios em diversos setores da economia.

O elevado número de acordos e a expressividade do volume financeiro envolvido nestas operações demonstram a necessidade de reflexão sobre como elas contribuem para a geração de valor efetivo para as empresas, para os profissionais envolvidos e, também, para os países onde se localizam estas organizações. Analisando-se a opinião de consultores, pesquisadores e executivos sobre o assunto, diversas versões são encontradas sobre os reais benefícios e desafios que se configuram para as empresas. É interessante perceber também que muita atenção é dada a aspectos financeiros, mercadológicos e legais, demonstrando que os líderes normalmente tendem a deixar para segundo plano outros elementos igualmente importantes como os padrões culturais, relações de poder e características do processo de transição que influenciam a modelagem das novas configurações organizacionais decorrentes das operações de combinação.

Além disso, os estudos sobre este tema, mencionando indicadores de efetividade das operações realizadas, demonstram alguns dados bastante preocupantes. De acordo com as publicações sobre o assunto, verifica-se que aproximadamente entre 15 e 25\% das operações de aquisições e fusões atingem os resultados financeiros esperados (Haspeslagh \& Jemison, 
1991; Marks \& Mirvis, 1998; Ernst \& Havely, 2000; Selden \& Colvin, 2003; Lajoux, 2006). Se inseridos no contexto atual, caracterizado pelo elevado número de acordos e correspondente volume financeiro envolvido, os poucos indicadores de sucesso identificados demonstram a necessidade de ampliar o conhecimento sobre este assunto. Diante disto, tornase fundamental analisar em profundidade a questão da gestão dos processos que resultam nas combinações empresariais, com o objetivo de influenciar a implementação de organizações efetivamente competitivas e alinhadas às orientações estratégicas que deram origem às decisões de realizar essas transações.

Esse tema dá continuidade aos estudos realizados pelo pesquisador na sua dissertação de mestrado, a qual enfocou a aprendizagem organizacional e o desenvolvimento de competências em organizações multinacionais. A utilização da capacidade de aprendizagem como vantagem competitiva sustentável (Nevis, Dibella \& Gould; 1995; Senge et alli, 1994; 1999) torna-se um discurso alinhado às necessidades organizacionais do momento atual, sensivelmente influenciado pela exigência constante de elevar os patamares de competitividade empresarial. De acordo com os resultados da pesquisa realizada, o desafio que se configura para as organizações consiste na transformação deste discurso de aprendizagem em práticas de gestão que criem condições para o incremento da performance organizacional.

No caso das aquisições e fusões, o fortalecimento da capacidade de aprendizagem das empresas envolvidas torna-se condição de extrema relevância, diretamente relacionada à efetividade da operação. Sabe-se que os processos de aquisições e fusões expõem e, muitas vezes, ampliam a diversidade encontrada nos padrões culturais, diretrizes estratégicas, modelos organizacionais, políticas e instrumentos de gestão das organizações participantes do acordo. Diante desta diversidade, o processo de gestão da mudança, desenhado para fortalecer a capacidade de adaptação das organizações, torna-se fator crítico de sucesso para alcançar os objetivos estratégicos propostos pela combinação empresarial.

Mais do que a capacidade de adaptação, o desafio proposto aos líderes destas operações consiste na criação de uma dinâmica de aprendizagem, propiciando a identificação dos conceitos e práticas presentes nas empresas e que devem ser mantidos no modelo organizacional resultante da transação entre as organizações. O aproveitamento e a 
potencialização destes elementos cria condições para o aumento da efetividade das operações de combinação, através da obtenção de patamares diferenciados de performance da nova configuração empresarial. Marks \& Mirvis (1998) elaboram, alinhados a esta proposição, o conceito de combinação produtiva, na qual a organização resultante da integração tem características positivas que a torna superior à simples somatória das práticas de gestão das empresas que lhe deram origem.

\section{Colocação do problema de pesquisa}

Os processos de combinação empresarial apresentam-se bastante longos e complexos. Os autores que elaboram pesquisas sobre o tema apontam diversas etapas para a sua concretização, que vão desde as análises preliminares de cenários e da viabilidade das aquisições e fusões, até o momento de consolidação do modelo organizacional proposto para a nova empresa decorrente da operação.

Esta tese não tem a intenção de explorar toda a complexidade do fenômeno de combinação empresarial, mas sim identificar e propor elementos para o aprimoramento da sua gestão, que propiciem elevar os patamares de desempenho das empresas que passam por processos desta natureza.

É importante salientar que o foco desta reflexão não deve se restringir ao questionamento da decisão para a realização da aquisição ou fusão. A implementação da operação de aquisição ou fusão, muitas vezes, torna-se uma questão de sobrevivência para as empresas no contexto atual, principalmente diante das pressões de crescimento e de elevação dos patamares de desempenho para fazer frente aos desafios da concorrência.

O ponto relevante para discussão e aprimoramento do processo de gestão destas operações corresponde à análise do modelo de gestão de mudança adotado e quanto ele é adequado para viabilizar uma integração efetiva entre as empresas participantes da transação, garantindo a implementação das diretrizes estratégicas e da proposição de negócio que motivaram a combinação organizacional. 
Vale a pena ressaltar também que esta análise não pode se referir genericamente a qualquer tipo de empresa. As especificidades dos setores da economia e das fronteiras estabelecidas entre as indústrias têm influência direta no desenho das estratégias orientadoras da combinação, bem como nos modelos de mudança organizacional adotados para a sua concretização. O problema de investigação proposto deve ser delimitado, portanto, com o estudo de organizações específicas de um setor econômico para que a descrição das características estruturais e conjunturais permitam melhor compreensão e maior profundidade de análise do fenômeno pesquisado.

O setor de produção econômica escolhido deve apresentar características que propiciem uma observação rica e consistente do fenômeno de combinação organizacional, tornando possível a compreensão integrada das estratégias e dos processos de gestão de mudança das aquisições e fusões realizadas entre as empresas.

A formação e o desenvolvimento do conceito de ciências da vida ${ }^{1}$ no setor da indústria química reúne estas características, uma vez que vem sendo permeado por freqüentes e complexas combinações, as quais remodelam o porte e o desempenho das organizações que o compõem, assim como os padrões de relacionamento entre elas. Diversas empresas químicas multinacionais vêm reconfigurando o seu foco de negócios, passando de uma atuação baseada em commodities para uma especialização em ciências da vida a partir de sucessivas cisões, fusões e aquisições. Wongtschowski (1998, 2002) demonstra que, através da implementação de estratégias de especialização e de concentração de empresas nesta indústria, foram criadas organizações de grande porte, que se beneficiaram de oportunidades decorrentes de ganhos de escala nas últimas décadas. Segundo o Autor:

\footnotetext{
"Empresas tradicionais como a Monsanto, a Rhône Poulenc e a Hoechst estão deixando de ser empresas químicas de amplo espectro de atuação para se transformarem em especialistas em “ciências da vida”, termo novo no jargão químico que pode incluir a indústria farmacêutica, a fabricação de defensivos agrícolas e de produtos de saúde animal.” (Wongtschovski, 1998, p.15).
}

\footnotetext{
${ }^{1} \mathrm{O}$ termo ciências da vida, ou biociências, tem sido utilizado pelas organizações químicas na formulação de suas estratégias de gestão. Na literatura, Wongtschoski (2002) faz uma definição deste conceito, delimitando-o pela especificação dos seus produtos, ou seja, substâncias químicas que interagem com o ser humano, animais, plantas e outras espécies de seres vivos.
} 
A intensidade da dinâmica de mudanças pode ser avaliada pelas significativas alterações vivenciadas por algumas destas empresas em apenas alguns anos após a publicação do Autor. A tradicional Hoechst deixou de existir a partir da fusão da sua unidade de ciências da vida com o grupo Rhône Poulenc, formando a empresa Aventis, e da fusão da sua divisão de química tradicional com a Sandoz transformando-se em Clariant. Pouco tempo depois, a mesma Aventis passou por nova modificação, concentrando o seu foco em produtos farmacêuticos e cindindo a sua divisão de defensivos agrícolas, a qual foi comprada pela Bayer em 2001 por US\$ 6,6 bilhões (Kotler \& Simon, 2004).

A evolução do conceito de ciências da vida a partir da tradicional indústria química, caracterizada por complexas cisões, fusões e aquisições entre organizações multinacionais de grande porte, demonstra a relação entre distintas orientações estratégicas e os correspondentes processos de mudança implementados pelas empresas para a viabilizar os seus objetivos de negócios.

A delimitação do trabalho de investigação no processo de gestão de mudança das operações de combinação empresarial e a escolha do setor de ciências da vida levam à proposição do seguinte problema de pesquisa:

Formular um modelo de gestão de mudança organizacional e utilizá-lo para compreender uma operação de combinação empresarial, que levou ao desenvolvimento do conceito de ciências da vida na indústria química.

O problema de pesquisa mencionado desdobra-se nos seguintes objetivos específicos, os quais foram explorados ao longo desta tese:

- Sistematizar o referencial teórico disponível sobre aquisições e fusões entre empresas, identificando as razões estratégicas que direcionam a realização destas combinações entre organizações, assim como as etapas cumpridas para a sua efetivação, independente do setor da economia ou origem do capital das entidades participantes; 
- Elaborar referencial teórico sobre gestão de processos de mudança organizacional e aplicá-lo em operações de aquisições e fusões entre empresas;

- Utilizar o referencial construído para a formulação de modelo de gestão da mudança em combinações empresariais, identificando conceitos e práticas que devem ser implementados durante a transição para viabilizar uma integração plena entre as empresas participantes de processos desta natureza.

Ao escolher as empresas multinacionais químicas que focaram a sua atuação no setor de ciências da vida para a investigação empírica, o conjunto de objetivos específicos foi complementado com os itens abaixo:

- Fazer uma análise setorial da indústria química, identificando os fatores condicionantes para a formação e desenvolvimento do conceito de ciências da vida e a sua configuração atual, com foco nos principais fenômenos de combinação entre empresas multinacionais;

- Identificar os casos mais expressivos de aquisições e fusões neste setor e selecionar um deles para descrevê-lo e analisá-lo em profundidade, possibilitando a compreensão das diretrizes estratégicas estabelecidas para a realização da transação, assim como da abordagem de gestão de mudança implementada para a sua efetivação;

- Aplicar o modelo de gestão da mudança formulado para analisar o nível de desenvolvimento da abordagem de gestão de mudança implementada e identificar diferenças de opinião entre os profissionais das empresas participantes da operação, visando aprimorar o processo de integração entre as mesmas. 


\section{PARTE II: REFERENCIAL TEÓRICO}

\section{Introdução}

O referencial teórico deste trabalho inicia-se com um histórico das combinações entre empresas, apresentando a sua origem no século XIX e a sua evolução até a atualidade. Este panorama reforça a magnitude e a importância deste fenômeno, ao mesmo tempo em que evidencia uma série de desafios para a eficácia da sua gestão.

Os indicadores de efetividade destas operações apresentados demonstram a necessidade de complementação do referencial teórico existente, viabilizando o alcance de patamares de desempenho mais satisfatórios. Para isso, busca-se uma compreensão maior da natureza destas operações, caracterizada pelos seus principais tipos, razões estratégicas que balizam a tomada de decisão para a sua efetivação, causas atribuídas ao baixo desempenho das organizações resultantes de aquisições e fusões e, por fim, etapas que devem ser cumpridas para a conclusão destas transações.

Este conjunto de conceitos formula as bases iniciais para a proposição do modelo de gestão de mudança delimitado no problema de investigação deste trabalho. Torna-se importante complementá-lo com uma discussão ampla sobre os processos de mudança organizacional, gerando insumos relevantes para o detalhamento da etapa de integração entre as empresas participantes de operações de combinação.

A segunda parte do referencial teórico aprofunda esta reflexão, discutindo a origem e desenvolvimento do conceito de mudança, concomitante à evolução da teoria administrativa. Os avanços teóricos relacionados à gestão de processos de mudança organizacional criam condições para a aplicação deste arcabouço conceitual às operações de aquisições e fusões entre empresas, complementando o modelo de gestão em formulação. 


\section{CAPÍTULO 1: CONCEITO E EVOLUÇÃO DAS COMBINAÇÕES ENTRE EMPRESAS}

\subsection{Histórico}

A necessidade de elaborar e implementar estratégias de combinações entre empresas já vem, há algum tempo, modelando as relações empresariais. Wasserstein (2000) coloca o início da era de aquisições e fusões no século XIX, com a ocorrência de algumas incorporações.

Foi neste período que o industrial Cornelius Vanderbilt adquiriu a Erie Railroad em 1868, criando um vasto império avaliado, na época, em mais de US\$ 100 milhões. Ainda neste século, o Autor destaca o papel de John D. Rockfeller, que construiu a Standard Oil com um pequeno investimento em uma refinaria em Cleveland e tornou-se responsável pelo controle de 90\% do negócio de petróleo nos Estados Unidos em 1880, a partir da aquisição de outras refinarias, empresas de pesquisa e instituições relacionadas a esta cadeia de valor. Vale a pena destacar também o papel de J. P. Morgan, que adquiriu o controle de um grupo formado pelas maiores instituições financeiras, formando um vasto complexo bancário em 1912.

Marks \& Mirvis (1998) também destacam importância do século XIX para as combinações entre empresas nos Estados Unidos, quando relembram os processos de fusões que criaram outras gigantes empresas norte-americanas como a Dupont, a General Electric e a siderúrgica United States Steel, contribuindo para o desenvolvimento de importantes setores da economia deste país. Vale a pena destacar que o caso da United States Steel apresenta duas marcas relevantes no processo de evolução econômica dos Estados Unidos, conforme coloca Geisst (2003). De acordo com o Autor, esta empresa de destaque no setor siderúrgico foi a primeira organização mundial cujo valor ultrapassou a casa dos bilhões de dólares. Além disso, formada a partir da junção entre Carnegie Steel e J. Perpont Morgan’s Federal Steel Corporation, esta empresa transformou o magnata Andrew Carnegie no homem mais rico do planeta desta época.

Este fenômeno é analisado também em referências bibliográficas clássicas de teoria organizacional. Chandler (1962) identifica este processo de incorporações como integração horizontal, decorrente do excesso de capacidade produtiva das empresas levando à 
necessidade de aumento da participação nos mercados emergentes da época. De acordo com o Autor, havia forte intenção de expansão, particularmente nos períodos posteriores à Guerra Civil nos Estados Unidos e anteriores à depressão ocorrida no início da década de 1870, manifestada pelos executivos das empresas em busca de crescimento em novos mercados. Diante da retração dos mercados e da queda dos preços dos produtos manufaturados ocorrida nesta época, várias empresas identificaram como atraentes as oportunidades de combinação para limitar a competição por meio de controle de preços e dos processos produtivos. Este fenômeno também foi identificado por outra referência clássica da teoria administrativa. Miles \& Snow (1978) mencionam o processo de combinação empresarial denominando-o de crescimento horizontal. Estes autores iniciam uma interessante reflexão sobre as diretrizes estratégicas destas operações, mencionada posteriormente neste trabalho, em seção específica sobre natureza estratégica das combinações empresariais.

Ao analisar a evolução do fenômeno das combinações entre empresas ao longo dos anos, Wasserstein (2000) identifica alguns ciclos de crescimento com fronteiras bem definidas. O primeiro ciclo, de acordo com o Autor, inicia-se com a construção do império de Vanderbilt e termina na primeira década do século XX com uma quebra no mercado de ações em 1907. Após significativa onda de consolidações decorrentes das integrações, o que levou ao desaparecimento de aproximadamente 3000 empresas, uma ou duas companhias passam a emergir como destaque nos diversos setores da economia norte-americana como, por exemplo, petrolífero, químico e açucareiro. Ainda neste período, o Autor verifica um avanço significativo na formulação de legislação específica para regulamentação destas aquisições e fusões e destaca a criação do Sherman Antitrust Act de 1890, iniciando um controle maior sobre estas operações.

Outro ciclo de crescimento é apontado por Wasserstein (2000) após a Primeira Grande Guerra, quando indústrias mais antigas como a química, petrolífera e siderúrgica tiveram um crescimento significativo, assim como outros setores mais recentes e focados em tecnologias mais modernas - automobilística, aeronáutica e de comunicação - tiveram rápido desenvolvimento. Entre 1926 e 1930, segundo o Autor, ocorreram mais de 4600 fusões e as 200 maiores companhias dos Estados Unidos tornaram-se responsáveis por aproximadamente metade da riqueza gerada por organizações neste país. 
Marks \& Mirvis (1998) também identificam este ciclo de crescimento e o localizam no período entre 1925 e 1931, a partir de decisões favoráveis dos tribunais em contraposição à legislação criada anteriormente, viabilizando a efetivação de grandes incorporações e junções entre empresas. Os Autores verificam também neste momento um forte movimento de integrações verticais, através da compra de distribuidores e clientes, assim como fornecedores dentro da cadeia de valor, levando à criação de gigantes como a American Cyanamid, a General Foods e a Radio Corporation of América.

Esta significativa expansão foi freada pela Depressão, no final de década de 20, e começou a sua retomada de crescimento apenas na Segunda Grande Guerra e período imediatamente posterior quando, segundo Marks \& Mirvis (1998), as grandes empresas passaram a procurar novas alternativas para investimento e crescimento.

O terceiro ciclo de fusões é identificado por Wasserstein (2000) a partir da década de 60, quando as 200 maiores companhias industriais controlavam mais de 60\% dos ativos de manufatura dos Estados Unidos. Esta nova onda de acordos foi caracterizada pela diversificação, ao invés de concentração conforme os movimentos anteriores, levando ao surgimento de grandes conglomerados. Muitos destes, entretanto, provaram-se ineficientes e geraram posteriormente, principalmente nas décadas de 80 e 90, um movimento de vendas e cisões resultando na criação de empresas com foco de atuação mais específico.

Durante a década de 70, dois grandes acordos demonstram uma nova tendência destas operações, caracterizada por Marks \& Mirvis (1998) como um outro tipo de aquisições. A compra da Montgomery Ward pela Móbil em 1974 por US\$ 1,6 bilhões e, no ano seguinte, a incorporação da Utah International pela GE no valor de US\$ 1,9 bilhões, caracterizam a realização de acordos em decorrência de oportunidades financeiras, modificando o escopo e caracterização das negociações. Em primeiro lugar, diante de expressividade do volume de ativos movimentado, atingindo cifras até então inimagináveis. Além disso, enquanto anteriormente empresas emergentes saíam do anonimato diante das aquisições e processos de crescimento, a partir deste momento, empresas tradicionais e reconhecidas pelo seu conservadorismo passam a fazer combinações e implementar processos de mudança de larga escala gerando rupturas nos seus modelos de gestão, eliminação de diversos postos de 
trabalho considerados até então como estáveis e, conseqüentemente, colapso em padrões culturais consolidados.

Os anos 80 são denominados por Wasserstein (2000) como a “década dos acordos”. Neste período, ao mesmo tempo em que muitas empresas passam a reestruturar o seu foco de atuação, novas tecnologias de comunicação e informática geram diversas oportunidades. A expansão destas novas indústrias, bem como a maturação das mais antigas, leva à geração de diversos processos de combinações e cisões, remodelando diversas cadeias industriais. Marks \& Mirvis (1998) apresentam uma pesquisa publicada pelo Journal of Management Development, que destaca o envolvimento de pelo menos $25 \%$ da população norte americana em processos desta natureza implementados nas empresas durante esta década. Neste momento, é importante destacar o surgimento de duas poderosas técnicas financeiras para viabilização deste movimento de expansão - os junk bonds e os leveraged buyouts (LBOs) através dos quais a compra das empresas pode ser iniciada através de financiamentos estruturados.

Na década de 90, o volume financeiro envolvido passa a subir vertiginosamente uma vez que grandes companhias passam a unir-se com outras empresas do mesmo porte. Neste período, Marks \& Mirvis (1998) verificam que as combinações de larga escala passam a configurar-se de distintas maneiras. Apesar das integrações horizontais ainda permanecerem dominantes, integrações verticais voltam a acontecer com maior freqüência a partir da consolidação do conceito de cadeia de valor. Além disso, os Autores identificam “operações concêntricas” nas quais organizações adquirem outras diante de determinada competência como, por exemplo, pesquisa, portfolio de produtos ou força de vendas. O termo concêntrico relaciona-se à rápida absorção das atividades relacionadas à competência desejada e conseqüente eliminação ou venda dos processos e atividades remanescentes.

\subsection{Magnitude destas operações no momento atual}

O crescimento do número de acordos de combinação entre empresas na década de 90 aparece evidenciado pelo Instituto Thompson Financial. De acordo com esta organização, o número de operações de aquisições e fusões teve um crescimento expressivo na última década, 
atingindo o seu valor máximo no ano de 2000, correspondente a quase 30.000 acordos efetivados.

Merece destaque nos relatórios produzidos também a análise do volume financeiro envolvido nestes acordos. Se pesquisado este mesmo intervalo de tempo, observa-se crescimento significativo de mais de 50\%, passando de US\$ 2,3 trilhões em 1999 para US\$ 3,6 trilhões em 2000.

As informações deste Instituto demonstram que o maior volume de negócios realizados neste período encontra-se nos Estados Unidos. No ano de 2000, pelo menos 50\% das operações ocorreram com empresas de capital norte-americano. Neste país também ocorreram as maiores fusões globais, respectivamente a operação AOL-Time Warner, realizada em janeiro de 2000; a compra da Warner Lambert pela Pfizer em junho de 2000; e, a fusão Exxon-Móbil no final de 1998.

A magnitude deste fenômeno nos Estados Unidos é demonstrada pelo gráfico a seguir, que apresenta as operações supra bem como as demais, que foram consideradas as 15 maiores fusões realizadas neste país.

\section{Gráfico 1: As maiores fusões dos EUA (US\$ bilhões)}

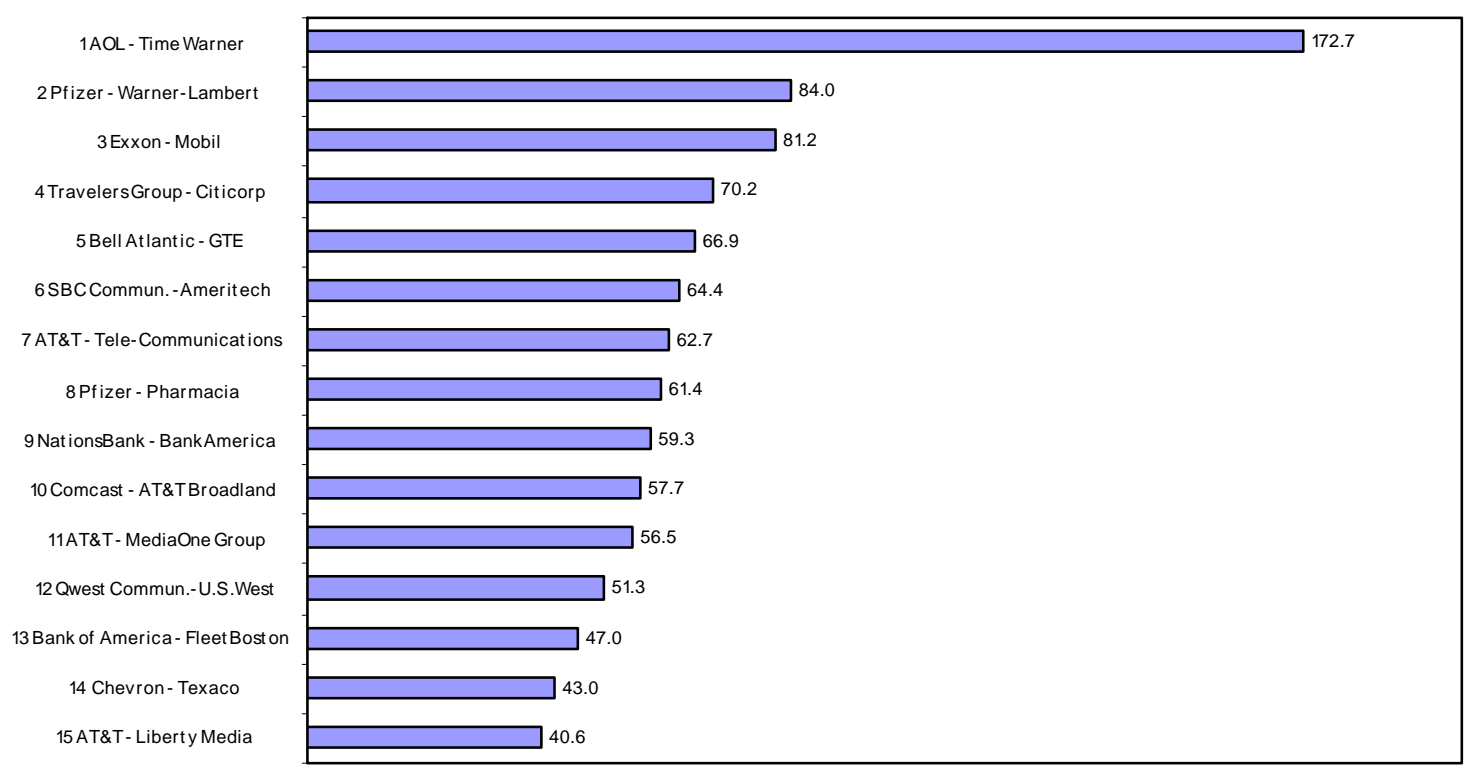


Os valores alcançados em 2000, tanto em termos do número de acordos realizados quanto em relação ao volume financeiro envolvido, representaram um patamar elevado e que ainda não foi alcançado nos anos posteriores. Vários fatores podem ser relacionados a esta tendência, entre os quais destacam-se:

- A concentração dos mercados em determinadas indústrias, inviabilizando a efetivação de novas operações de aquisições ou fusões, diante da necessidade de venda e transferência de produtos, que ocorre em decorrência da legislação antitruste;

- O estouro da bolha de crescimento da nova economia, diminuindo consideravelmente o ritmo de operações entre empresas com negócios na internet;

- O ataque terrorista de "11 de setembro" e seus desdobramentos, criando adversidades macro-econômicas para os Estados Unidos a partir de 2001.

Os anos posteriores apresentaram cifras menores, porém com tendência de aumento expressa através da evolução verificada entre os anos de 2002 e 2004, conforme demonstra o gráfico abaixo elaborado pelo Instituto Thomson Financial.

\section{Gráfico 2: Evolução das aquisições e fusões entre 2002 e 2004: volume financeiro}

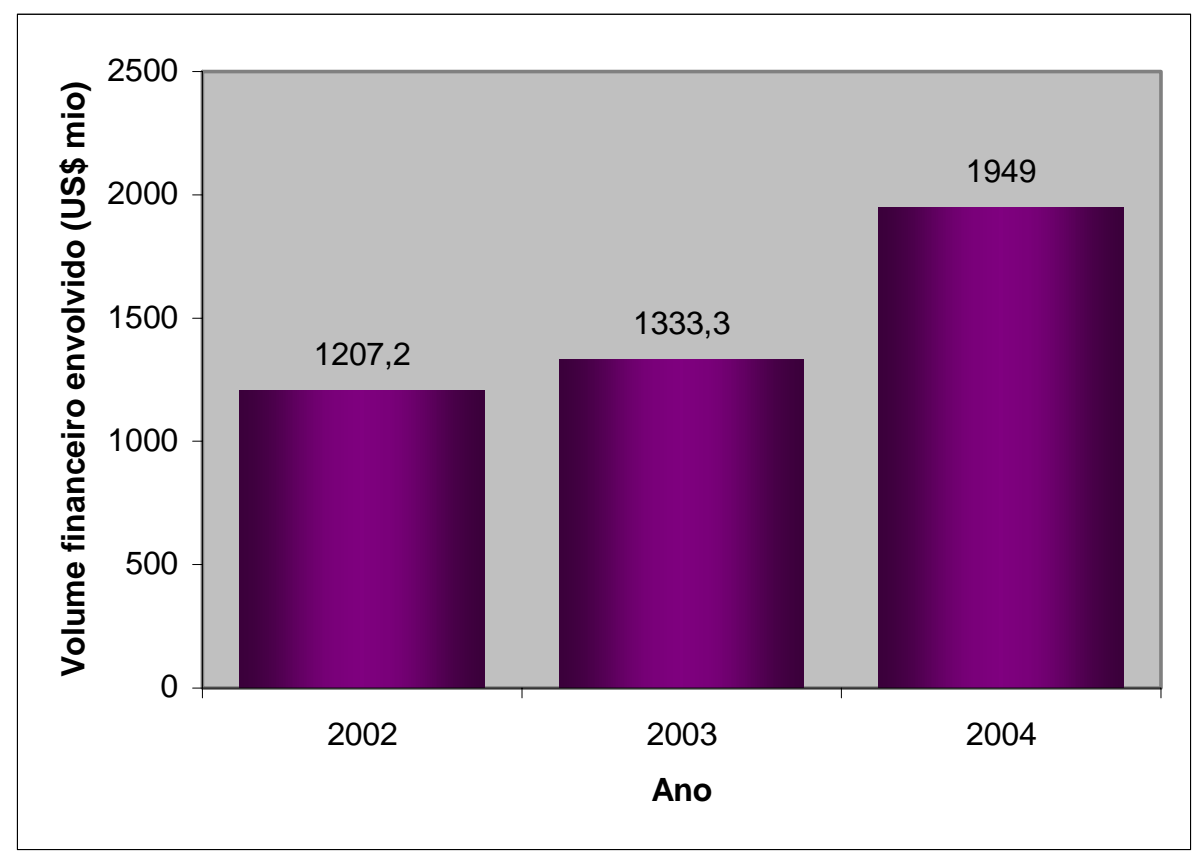

Fonte: Thomson Financial Institute(2005)

Os resultados expressos no gráfico refletem o volume financeiro envolvido em operações de aquisições e fusões durante os anos mencionados. É interessante observar que apesar de não 
alcançar o volume envolvido nestes acordos no ano de 2000, verifica-se que em 2004 houve um crescimento de 46\% em relação aos valores do ano de 2003.

O gráfico a seguir faz uma análise dos mesmos anos, porém enfocando o número de acordos realizados. Pode-se observar uma tendência de crescimento semelhante; entretanto, com uma evolução menor, equivalente a 9\%, quando comparados os valores de 2003 e 2004.

Gráfico 3: Evolução das aquisições e fusões entre 2002 e 2004: número de acordos

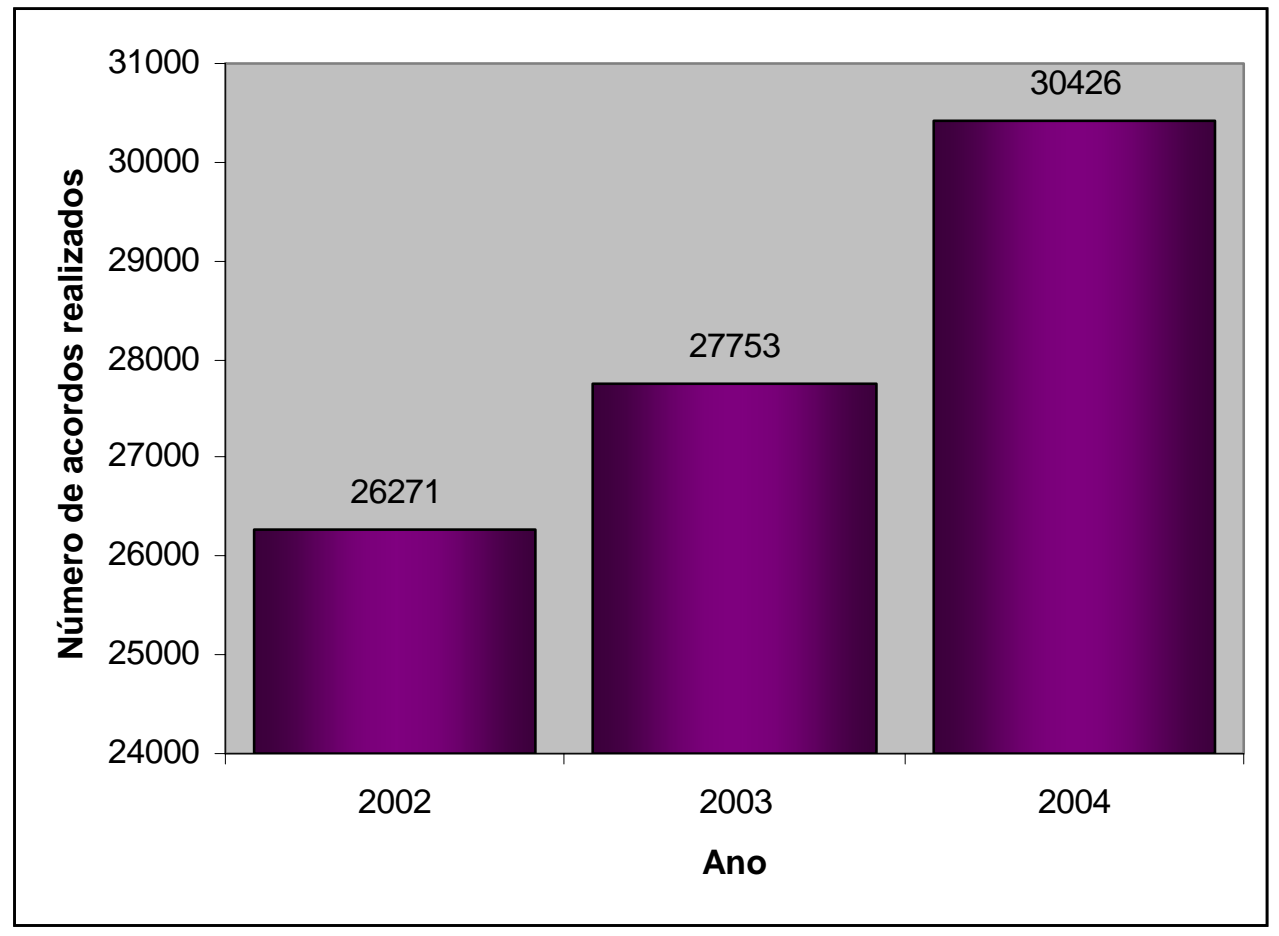

Fonte: Thomson Financial (2005)

De acordo com os analistas deste Instituto, há uma tendência de crescimento para o ano de 2005 ou, pelo menos de manutenção dos patamares alcançados em 2004. Como principal fator para o crescimento, é apontada a recuperação do mercado de capitais dos Estados Unidos, viabilizando a obtenção de financiamentos e orientando, portanto, as empresas para a busca de novas oportunidades de negócios. O Instituto aponta também que a revitalização destas operações nos Estados Unidos apresenta tendência semelhante nas demais regiões globais.

De qualquer forma, apesar do crescimento verificado em 2004 em relação ao ano anterior e a possível tendência de aumento para os próximos anos no número de acordos, assim como no 
volume financeiro envolvido, ainda é cedo para afirmar o retorno do volume recorde, alcançado no ano de 2000.

A próxima seção deste trabalho demonstra que a evolução do Brasil, a partir da década de 90, apresenta-se análoga à situação norte-americana no mesmo período.

\subsection{Colocação da questão no Brasil}

O fenômeno das combinações empresariais no Brasil também pode ser verificado com maior intensidade a partir da década de 90. Rossetti (2001) justifica o aumento de ocorrências neste período a partir da percepção de mudança da orientação estratégica da economia nacional. Segundo o Autor, até o final dos anos 80, a estratégia do governo brasileiro teve como base o princípio de protecionismo da indústria local, caracterizado por reservas de mercado, concessão de incentivos para o crescimento e desenvolvimento do parque industrial privado e estatização nos segmentos considerados estratégicos como, por exemplo, mineração, petroquímica e telecomunicações. A presença de empresas estrangeiras no país, tal qual ocorreu em setores como o químico, farmacêutico e automobilístico, somente foi aceita em decorrência da verificação da insuficiência de capacitação tecnológica nacional.

A mudança estratégica verificada no início da década de 90 ocorreu para viabilizar a inserção da economia nacional no mercado global. Em primeiro lugar, houve uma diminuição das barreiras de entrada de capital estrangeiro até então estabelecidas. Segundo Rossetti (2001), no final dos anos 80, as tarifas médias de proteção da indústria nacional eram superiores a $40 \%$ e foram gradativamente abaixando até alcançar, no final de década de 90, valor aproximado a 12\%. Além disso, houve uma intensificação dos fluxos mundiais de investimento no Brasil diante da maior atratividade do país.

Paralelamente, começou a ser verificado o movimento de privatização de alguns setores da economia levando a um menor nível de estatização. Héau (2001) identifica este processo como impulsionador das aquisições e fusões no país a partir da privatização de alguns setores da economia como, por exemplo, transporte, indústria pesada e telecomunicações. 
Outro fator apontado corresponde ao processo de mudança de gerações pelo qual muitas empresas familiares têm passado. Após longo período de sucesso destas organizações, as novas gerações não demonstram interesse ou não se sentem capacitadas para manter os mesmos patamares de desempenho e passam a implementar ações orientadas para a profissionalização ou venda destes negócios (Héau, 2000; Rossetti, 2001).

\subsection{Razões que levam às combinações entre empresas}

A expressividade dos movimentos de integração entre organizações apresentada demonstra a necessidade de reflexão estruturada sobre as principais razões que levam as empresas a tomarem este tipo de decisão.

Weisserstein (2000), ao resgatar o histórico deste fenômeno, apresenta cinco forças elementares as quais identifica como motivadoras de praticamente todas as operações realizadas ao longo do tempo. A primeira delas tem natureza política e está diretamente ligada à desregulamentação, que cria um clima propício e as condições necessárias para que as organizações implementem ações de expansão e se tornem mais competitivas.

A segunda força apresentada pelo Autor é a tecnologia e o decorrente impulso para a globalização. Através dela, são criados novos mercados, competidores e indústrias. Wasserstein (2000) menciona também a redefinição de fronteiras industriais ao explicar a terceira força, relacionada à flutuação dos mercados financeiros e conseqüente disponibilidade de capital para o crescimento das empresas.

A próxima força é a liderança e o estilo expansionista de alguns dirigentes empresariais como é o caso, segundo o Autor, de Jack Welch da GE e Mike Armstrong da AT\&T, que desempenharam papel semelhante ao de J. P Morgan e John D. Rockfeller no início dos processos de aquisição de outras organizações. A quinta força tem natureza análoga e está relacionada ao modelo mental de que o tamanho é uma variável crítica para o sucesso dos negócios. De acordo com o Autor, a grande maioria dos gestores acredita no imperativo de que quanto maior for a sua organização ou divisão, melhores serão os resultados operacionais alcançados. 
Héau (2001) busca aprofundar as variáveis macroeconômicas e tecnológicas para justificar o aumento das operações de aquisições e fusões. Entre elas, ele destaca o aumento da concorrência, bem como da sua sofisticação, decorrente da desregulamentação e do fácil acesso a recursos. Diante disto, companhias que haviam implementado movimentos de diversificação passam a abandonar atividades secundárias e buscam concentração naquelas que possibilitam a consolidação de seus diferenciais competitivos. Para a alavancagem destas competências básicas, torna-se fundamental a expansão e obtenção de vantagens de economia de escala.

O Autor complementa a sua análise de natureza econômica com a globalização, gerando a necessidade das empresas comercializarem os seus produtos em mercados globais. Nos casos de expansão de atividade em determinados países, a aquisição de empresas nacionais possibilita a derrubada de barreiras de entrada relacionadas a rede de relacionamentos, ou mesmo compreensão dos padrões culturais específicos do país, viabilizando uma atuação mais efetiva no contexto local de negócios.

Outro fenômeno de natureza macroeconômica apresentado corresponde à fluidez de fronteiras comerciais. A desregulamentação identificada por Héau (2001), juntamente com o avanço da tecnologia da informação, estimula a quebra e a redefinição de determinadas cadeias de valores. Dicken (2000) estabelece uma relação direta entre o desenvolvimento da tecnologia de informação, a formação de networks globais e a redefinição de fronteiras entre algumas indústrias levando a novas configurações do modelo de negócios das empresas.

Diante destas variáveis, é importante destacar o aparecimento de diversas oportunidades financeiras para a realização de incorporações entre as empresas viabilizando estratégias de crescimento. Héau (2001) identifica um enorme volume de liquidez disponível, decorrente da maior expressividade dos mercados de capitais. Além disso, a perspectiva de grandes operações abriu linhas de negócios específicas dos bancos de investimento, que passaram a atuar na obtenção de financiamentos bem como prestação de serviços de consultoria. É interessante verificar o alto nível de estruturação da metodologia para suporte a processos de aquisições e fusões elaborados por bancos como Goldmann Sacks, Morgan Stanley e Deutsch Bank. O referencial construído por estas instituições fornece insumos para as empresas 
clientes em praticamente todas as fases do processo, desde a decisão do investimento até as práticas de integração após a efetivação das negociações.

A compreensão da complexidade do fenômeno pesquisado neste trabalho demanda uma reflexão sobre os principais tipos de combinação entre empresas, as estratégias que levam à sua implementação e a análise da efetividade destas operações no momento atual, tópicos que são apresentados na seqüência.

\subsection{Principais tipos de combinações}

O termo combinação foi escolhido com o objetivo de descrever as diversas alternativas de configuração organizacional que levam à efetivação das estratégias de crescimento das empresas. Marks \& Mirvis (1998) identificam estas diferentes formas a partir de variações nos níveis de investimento, controle, necessidade de integração, possibilidade de reversão do acordo e demais impactos no modelo de gestão. O quadro abaixo demonstra estes diferentes tipos, bem como a relação com as variáveis propostas.

\section{Quadro 1: Tipos de combinações entre empresas}

\begin{tabular}{|c|c|c|c|c|}
\hline Licença & Aliança/Parceria & Joint Venture & Fusão & Aquisição \\
\hline Baixo(a) & & $\begin{array}{c}\text { Investimento } \\
\text { Controle } \\
\text { Impacto } \\
\text { Integração } \\
\text { Dificuldade } \\
\text { Reversibilidade }\end{array}$ & & Alto(a) \\
\hline
\end{tabular}

Fonte: Marks \& Mirvis (1998)

De acordo com os Autores, a interação entre empresas com o objetivo de viabilizar o licenciamento de um produto ou serviço tem um impacto pouco significativo nas variáveis mencionadas, ou seja, os esforços de integração, controle e investimentos. Caminhando neste continuum, a aliança estratégica configura uma parceria entre diferentes entidades visando alcançar os objetivos estratégicos de ambas as instituições. 
O potencial de parcerias entre empresas é apresentado por Brandenburger \& Nalebuff (1996), que demonstram na sua publicação a complementariedade entre a cooperação e a competição para a obtenção de padrões de desempenho diferenciados. Segundo os Autores, as empresas atuam de maneira cooperativa no momento de construção da torta e competem no momento de dividi-la.

Marks \& Mirvis (1998) identificam na seqüência do seu modelo de análise as joint ventures, representando uma configuração na qual uma nova organização é constituída, a qual encontrase separada das demais, com estrutura e modelo de governança, políticas e processos independentes. Dessa forma, as dificuldades de controle e integração apresentam intensidade mediana.

Dando continuidade ao modelo analisado, encontram-se as aquisições e fusões. De acordo com os Autores, a aquisição é a mais dramática das operações. Utilizando a metáfora de casamento, neste tipo de operação:

“a empresa que adquire ou o parceiro dominante assume a responsabilidade de redesenhar a organização adquirida, exercendo pressões para a mudança dos seus padrões culturais. As dificuldades, como resistência à mudança, tornam-se presentes quando os valores e crenças não são aceitos pela organização compradora.” (Marks \& Mirvis, 1998, p.11).

Os Autores fazem também uma interessante comparação entre as aquisições e as alianças estratégicas. De acordo com eles, historicamente os executivos têm preferido as primeiras em relação às segundas em decorrência da possibilidade de exercer o comando. Além disso, as alternativas de alianças tornam-se atraentes uma vez que possibilitam a busca de interdependência ao invés de dominância. Ernst \& Halevy (2000) reforçam este ponto de vista demonstrando que as aquisições são reconhecidas pelo mercado em geral como menos efetivas do que alianças estratégicas, prejudicando a credibilidade do seu futuro sucesso e, conseqüentemente, gerando impactos negativos no valor da empresa resultante da operação.

Barros (2003) utiliza o modelo proposto por Marks \& Mirvis (1998) nas suas reflexões sobre os casos de sucesso e fracasso em aquisições e fusões envolvendo empresas brasileiras. A 
Autora acrescenta a este referencial de análise uma nova modalidade de operação - a cisão com efeito inverso ao das aquisições e fusões uma vez que ocorre a separação da empresamãe. Quanto aos níveis de complexidade e dificuldade, a Autora classifica este tipo de operação como um padrão semelhante à aquisição, com alta intensidade de desafios para a sua gestão organizacional.

Outro tipo de operação que pode ser acrescentado no modelo é apresentado por Rossetti (2001) na sua proposta de tipologias para as combinações entre empresas. O Autor identifica o consórcio, definido com um "grupo de empresas formado para a aquisição de outra empresa”, complementando a definição da aquisição apresentada no continuum proposto por Marks \& Mirvis (1998).

O grupo francês Strategor (1997) faz uma análise jurídica das aquisições e fusões e identifica três categorias principais. A primeira delas é a fusão, na qual distintas organizações decidem integrar o seu patrimônio para formar uma única sociedade. Esta categoria, segundo o grupo, divide-se em igualitária, quando os tamanhos entre as empresas são comparáveis entre si e absorção quando as dimensões empresariais são significativamente diferentes.

A segunda categoria identificada é a cisão na qual uma empresa desaparece a partir do aporte do seu capital a duas ou mais organizações existentes, visando reestruturar atividades de naturezas distintas coexistindo na mesma companhia. O grupo também apresenta a terceira tipologia, denominada aporte parcial de atividades, na qual a empresa aporta parte do seu ativo a uma outra organização que, em contrapartida, lhe cede ações decorrente do aumento do seu capital.

Pritchet (1997) também faz uma análise das combinações, dividindo-as em quatro categorias a partir da razão que levou à operação, e faz uma análise dos elementos facilitadores e restritores ao futuro sucesso da mesma. São denominadas operações de resgate, colaboração, situação contestada e invasão.

Nos casos de resgate, a empresa compradora é bem-vinda uma vez que tem como objetivo salvar a empresa adquirida de uma tragédia diante dos seus resultados financeiros insatisfatórios. Nesta categoria, o Autor coloca também os casos em que a empresa que 
realiza a aquisição salva a empresa comprada de uma operação de incorporação hostil. Um exemplo deste tipo de situação ilustrado pelo Autor é o caso da Conoco. No início da década de 80, diante da possibilidade de ser comprada pela Seagram e Móbil, a Conoco visualizou melhores oportunidades no acordo de compra pela Dupont e optou pela transação com esta empresa.

A segunda categoria, denominada colaboração, apresenta-se de acordo com Pritchet (1997) como o tipo de operação que tem mais chances de obter resultados positivos. Isto ocorre em decorrência da existência de predisposição de ambas as partes da operação para a sua efetivação. Ainda assim, entretanto, armadilhas podem ocorrer após a efetivação do acordo diante de deficiências na gestão da integração, principalmente em aquisições nas quais os profissionais das empresas adquiridas normalmente apresentam-se extremamente sensíveis ao tratamento recebido pela organização compradora.

Nos casos denominados situação contestada, apenas uma das partes da negociação encontrase comprometida com o acordo a ser realizado. Podem ser incluídas nesta categoria também situações em que duas empresas têm objetivos extremamente dissonantes com a mesma operação. Os momentos de integração entre as empresas após o fechamento dos acordos, segundo o Autor, são permeados por situações de stress, transtornos e descontentamentos na população envolvida, criando obstáculos significativos para o alcance de desempenho satisfatório no futuro.

A quarta categoria denomina-se invasão e ocorre normalmente quando uma das empresas deseja comprar outra que, entretanto, não está disposta à efetivação do acordo. Estes casos são permeados por elevadas cargas de adversidades, bem como negociações de caráter emocional e baseados na personalidade das pessoas. O resultado natural deste tipo de processo é a percepção de vencedores e perdedores após uma batalha.

\subsection{Estratégia em operações de combinações empresariais}

Os casos de aquisições e fusões apontados por publicações, executivos e consultores relacionados ao tema caracterizam operações com motivos e escolhas estratégicas distintas. 
Sendo diversos os princípios norteadores da decisão de efetivação das transações, novos desafios se configuram e, conseqüentemente, cuidados devem ser tomados para garantir que os esforços de integração entre as empresas viabilizem as diretrizes estabelecidas inicialmente.

Ao analisar as referências bibliográficas sobre o tema, é possível observar diversas publicações sobre as estratégias em combinações empresariais, realizadas por empresas de consultoria tradicionais especializadas em aquisições e fusões ou mesmo por autores que já passaram por uma experiência desta natureza, seja como executivo ou como consultor. Diante da natureza acadêmica deste projeto, optou-se pela seleção de trabalhos essencialmente científicos, desenvolvidos por renomados centros de pesquisa, para iniciar esta reflexão. Além disso, é importante observar a evolução deste tema a partir de trabalhos clássicos de teoria organizacional que fazem menções às estratégias em combinações empresariais (Chandler, 1962; Miles \& Snow, 1978).

Chandler (1962) identifica duas diretrizes estratégicas características deste tipo de operação. A primeira delas corresponde à integração horizontal, decorrente do excesso de capacidade produtiva e conseqüente necessidade de ampliação de mercados. A segunda é a integração vertical, a qual leva à incorporação de diferentes elos na cadeia de negócios da empresa tais como os fornecedores de matérias primas ou as redes de distribuição no caso de produtos manufaturados.

É interessante verificar, na análise deste Autor, a influência da integração horizontal sobre a vertical. De acordo com Chandler (1962), as combinações horizontais resultantes do excesso de capacidade produtiva levaram ao aumento das atividades de manufatura com conseqüente incremento dos custos fixos das organizações. Estas empresas manufatureiras passaram então a considerar arriscada a dependência de distribuidores externos ou agentes comissionados. Além de vender produtos da concorrência, havia divergência de interesses entre as empresas e estes distribuidores como, por exemplo, a resistência em aumentar o volume de vendas para reduzir o custo unitário da manufatura. Diante disto, várias organizações passaram a implementar integrações verticais, constituindo operações próprias de distribuição e vendas diretas ao cliente final. 
O texto de Miles \& Snow (1978) também identifica estas duas razões estratégicas apontadas por Chander (1962) e as denomina de crescimento horizontal e vertical. A primeira delas ocorre, segundo os Autores, com o simples objetivo de expandir a atual linha de produtos ou mesmo participação de mercado em determinada indústria. De maneira complementar, o aumento vertical ocorre por meio da aquisição de fornecedores ou distribuidores, visando obtenção de vantagens competitivas de custo e excelência operacional.

Miles \& Snow (1978) ampliam o raciocínio de Chandler (1962), acrescentando uma terceira natureza estratégica. Os Autores classificam separadamente as combinações empresariais que extrapolam os limites da indústria original em que está localizada a empresa que implementa a transação e as denominam de formação de conglomerados. De acordo com a sua publicação, esta é a forma de combinação mais desafiadora diante da complexidade de gestão e necessidade de ampla revisão estratégica, adicional à captura de sinergias característica das transações de crescimento horizontal e vertical.

Dando seqüência às publicações acadêmicas sobre o assunto, Bower (2001) apresenta um estudo, realizado na Harvard Business School, através do qual pretende identificar as razões estratégicas que levam à efetivação das operações de combinação empresarial. Para isso, analisa todos os acordos de aquisições e fusões, com valores superiores a US\$ 500 milhões, realizados entre empresas norte-americanas no período entre 1997 e 1999.

O Autor faz uma análise em profundidade das ações de natureza estratégica destas operações com o objetivo de identificar categorias específicas. A partir dos resultados levantados, Bower (2001) identifica seis principais razões estratégicas para a efetivação de transações de aquisições e fusões. O gráfico a seguir apresenta as quantidades relativas a cada um dos tipos levantados durante o período em que foi realizada a pesquisa.

Gráfico 4: Razões estratégicas para a realização de aquisições e fusões

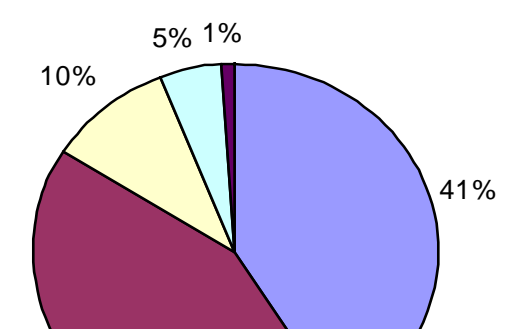

Overcapacity na indústria

$\square$ Expansão de produtos e mercados

$\square$ Expansão geográfica 
Fonte: adaptado de Bower (2001)

Uma vez analisadas estas três publicações de caráter essencialmente acadêmico, é interessante verificar o desdobramento destas pesquisas em trabalhos de autores e grupos relacionados a empresas de consultoria ou organizações que passaram por este tipo de transação.

Os trabalhos do grupo francês Strategor (1997) levam à identificação de categorias para facilitar a compreensão sistematizada dos acordos empresariais, promovendo uma reflexão de natureza análoga à pesquisa desenvolvida por Bower (2001). Os trabalhos do grupo levam à proposição das seguintes tipologias: aquisições horizontais, aquisições verticais, operações visando diversificação de negócios e formação de conglomerados. É possível observar também no trabalho deste grupo uma outra categorização das aquisições e fusões, identificando operações com motivação estratégica e outras de caráter essencialmente oportunista. A primeira categoria, segundo o grupo, apresenta a intenção de melhoria do posicionamento competitivo da empresa frente à concorrência, através da identificação e captura de sinergias entre as organizações participantes do acordo. No segundo caso, o principal objetivo destas operações está ligado à obtenção de ganhos de curto prazo, seja através da melhoria da gestão e resultados da empresa adquirida ou aproveitamento de empresas cuja avaliação do seu valor de mercado foi sub-dimensionada.

Outros autores relacionam a orientação estratégica das empresas à razão para a realização da sua integração com outras organizações. Nesta linha de raciocínio, Marks \& Mirvis (1998) propõem categorias denominadas diversificação de produtos e serviços, integração vertical, globalização, compartilhamento de risco, acesso à tecnologia e outros recursos, flexibilidade operacional, inovação e aprendizado, consolidação e, por fim, compartilhamento de recursos. Hindery (2003), em uma linha complementar de análise, busca através dos seus estudos 
sistematizar as razões estratégicas através da proposição de três tipologias principais: o aprimoramento, ligado à melhoria, ampliação ou mesmo mudança da base de ativos da empresa; a busca por ganhos de escala entre distintas operações; e, a mudança do modelo de atuação através da aquisição e entrada em novos negócios.

Selden \& Colvin (2003) reconhecem a existência de diversos motivos para a combinação de empresas; entretanto, buscam sintetizá-los em um único objetivo relacionado à aquisição de clientes. Considerando os maiores negócios dos Estados Unidos - AOL e Time Warner, Pfizer e Warner Lambert, Exxon e Móbil, Comcast e AT\&T Broadband, Verizon e GTE, Travelers e Citicorp, SBC e Ameritech, Pfizer e Pharmacia, Nations Bank e Bank of America, assim como Vedafone e AirTouch - os Autores afirmam que, na última instância, os compradores adquiriram as organizações para atender melhor clientes atuais, ou mesmo para obter novos proponentes.

A análise de conteúdo do trabalho dos autores mencionados leva à identificação de algumas semelhanças, viabilizando a construção de categorias que explicam a natureza estratégica das operações de combinação empresarial. A proposição destas categorias apresenta-se na tabela a seguir, utilizando-se como base os trabalhos de natureza acadêmica (Chandler, 1962; Miles \& Snow, 1978; Bower, 2001) e os desdobramentos destas pesquisas em trabalhos de natureza consultiva (Strategor, 1997; Marks \& Mirvis, 1998). 
Tabela 1: Proposição de categorias de estratégias para as combinações entre empresas

\begin{tabular}{|c|c|c|c|c|c|}
\hline $\begin{array}{l}\text { Proposta de } \\
\text { categorias }\end{array}$ & Chandler (1962) & Miles \& Snow (1978) & Bower (2001) & Strategor (1997) & $\begin{array}{l}\text { Marks \& Mirvis } \\
\text { (1998) }\end{array}$ \\
\hline $\begin{array}{c}\text { Integração } \\
\text { horizontal }\end{array}$ & 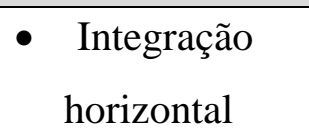 & 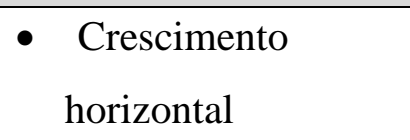 & $\begin{array}{l}\text { - } \text { Overcapacity }^{2} \text { na } \\
\text { indústria }\end{array}$ & 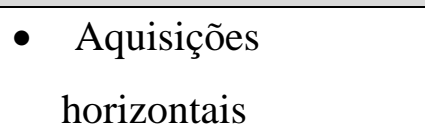 & - Consolidação \\
\hline - $\quad$ Expansão & & & 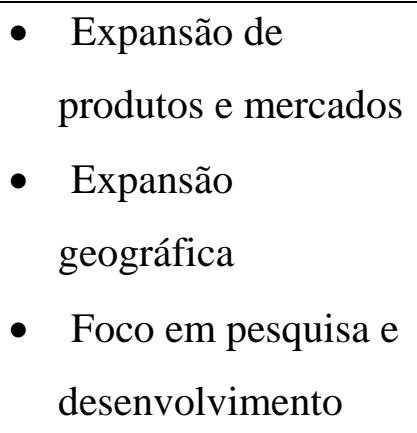 & 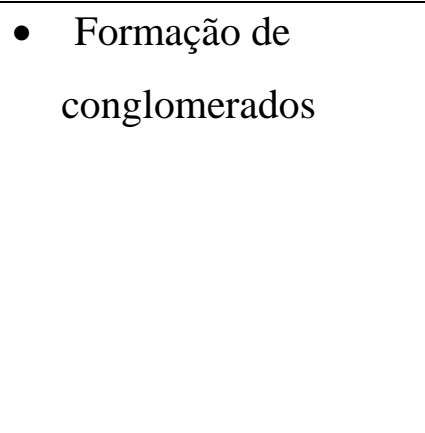 & 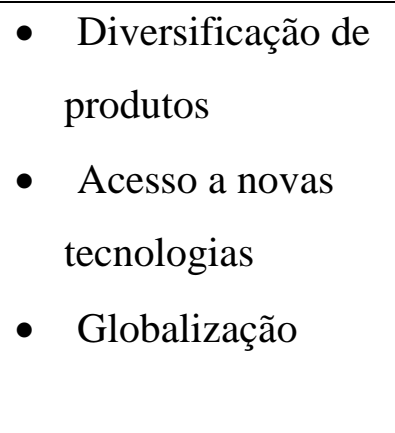 \\
\hline $\begin{array}{l}\text { - Integração } \\
\text { vertical }\end{array}$ & 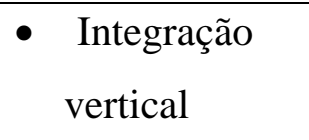 & $\begin{array}{l}\text { - Crescimento } \\
\text { vertical }\end{array}$ & & - Aquisições verticais & - Integração vertical \\
\hline $\begin{array}{l}\text { - } \text { Redefinição de } \\
\text { fronteiras na } \\
\text { indústria }\end{array}$ & & $\begin{array}{ll}\text { - } & \text { Formação } \\
\text { conglomerados } & \text { de }\end{array}$ & $\begin{array}{l}\text { - Convergência } \\
\text { industrial }\end{array}$ & $\begin{array}{l}\text { - Diversificação de } \\
\text { negócios }\end{array}$ & \\
\hline
\end{tabular}

\footnotetext{
${ }^{2}$ O termo overcapacity foi utilizado por Bower (2001) no seu artigo e mantido neste trabalho diante da dificuldade de sua tradução para o português sem alterar o sentido original proposto pelo Autor.
} 
São apresentadas na sequência as características de cada uma das quatro categorias formuladas: integração horizontal, expansão, integração vertical e redefinição de fronteiras. Elas contribuem para este trabalho formulando bases para a compreensão da formação e amadurecimento do conceito de ciências da vida na indústria química, conforme especifica a delimitação do problema de investigação proposto.

\subsubsection{Integração horizontal}

Esta categoria foi identificada nos trabalhos de todos os autores mencionados na tabela anterior com natureza estratégica análoga, porém com denominações distintas.

Bower (2001) faz um estudo bastante detalhado desta tipologia uma vez que, segundo o seu estudo com os acordos norte-americanos, as operações relacionadas à overcapacity na indústria apresentam-se como as mais freqüentes, ou seja, 37\% do total das transações analisadas. O fenômeno ocorre em indústrias nas quais, diante da alta capacidade instalada, as empresas precisam realizar combinações para viabilizar o seu crescimento por meio de incremento do volume de vendas e ganho de market share. De acordo com o Autor, essas indústrias tendem a ser mais antigas e de capital intensivo, tais como automotiva, siderúrgica e petroquímica. Além disso, neste tipo de operação, a premissa fundamental que origina a decisão é a "lei de sobrevivência na selva: devore ou seja devorado", viabilizando a sua atuação sustentável no mercado.

O grupo Strategor (1997) e Marks \& Mirvis (1998) também identificam esta natureza estratégica; entretanto, não a restringem aos setores de capital intensivo assinalados por Bower (2001). A estratégia de consolidação é observada por estes Autores de uma maneira mais ampla, localizando-a em diversos outros setores econômicos tais como saúde, financeiro, alimentação, telecomunicações e eletrônico.

Um ponto de convergência entre os autores assinalados corresponde à geração, através das transações realizadas, de organizações mais poderosas na sua indústria a partir da elevação da sua participação no mercado, domínio de tecnologias mais amplas e aumento da expertise dos seus profissionais. O desafio que se configura neste cenário corresponde à necessidade de 
identificação e implementação de modelos de operação mais eficientes, integrando elementos estratégicos e organizacionais.

É fundamental também que estas empresas garantam um foco no alcance de sinergias entre as operações evitando o aumento excessivo da sua base de custos. Este custo adicional pode estar na duplicação de plantas de manufatura, filiais e outras posições na estrutura, ou mesmo em linhas de produto semelhantes, que podem ser racionalizadas evitando redundâncias na abordagem ao mercado alvo. A não captura de potenciais sinergias pode prejudicar a competitividade das empresas, assim como o seu posicionamento dentro da indústria.

\subsubsection{Expansão}

Dentre os acordos relacionados à expansão das organizações, três tipos distintos de razões podem ser encontrados: a busca de novos territórios geográficos para a atuação da empresa; o aperfeiçoamento da linha de produtos e serviços que compõe o portfolio da organização; e, a complementação das atividades de pesquisa e desenvolvimento.

Bower (2001) apresenta os três tipos que compõem esta categoria como distintos na sua pesquisa e, a partir desta definição, calcula as suas ocorrências separadamente na pesquisa que desenvolveu identificando elementos específicos relacionados à natureza estratégica de cada um deles. A análise cuidadosa das suas definições, entretanto, possibilita a identificação de dois pontos em comum entre eles.

Em primeiro lugar, a expansão do território geográfico, a complementação do portfolio de produtos e o foco em atividades de pesquisa e desenvolvimento ocorrem predominantemente em momentos iniciais do ciclo de vida das indústrias caracterizando-se, portanto, com maior freqüência em setores econômicos mais recentes.

O segundo ponto em comum assinalado pelo Autor opõe-se diretamente às operações de integração horizontal discutidas na categoria anterior, na qual o crescimento torna-se condição fundamental para a sobrevivência das empresas diante da alta concentração de organizações na indústria. Dessa forma, no caso da categoria de expansão, a questão do 
território geográfico, dos novos produtos ou mesmo da aquisição de novas tecnologias apresenta-se como uma oportunidade que pode ser aproveitada independente das pressões de sobrevivência impostas pela indústria decorrentes do acirramento da concorrência.

Bower (2001) salienta também elementos específicos de cada um dos três tipos mencionados. Vale a pena frisar que, no caso da expansão geográfica, são freqüentes as aplicações de abordagens de ganho mútuo diante do baixo conhecimento das características locais dos territórios, facilitando o processo de incorporação das empresas. Ao serem compradas por uma organização maior, as pequenas empresas de um país têm acesso a novas tecnologias, processos mais modernos e maior disponibilidade de capital, aprimorando consideravelmente o seu modelo operacional.

Paralelamente, é importante destacar que a entrada em determinados países somente viabilizase através da aliança com empresas locais, uma vez que são colocados obstáculos à operação de subsidiárias com pleno controle de uma organização de outro país. Isto acontece em alguns países em desenvolvimento como, por exemplo, a China, mas também em outros países desenvolvidos como os Estados Unidos, nos quais há uma restrição clara às empresas estrangeiras que desejam realizar negócios dentro do seu território.

No caso da complementação do portfolio de produtos, Bower (2001) frisa a importância do cuidado com os processos de gestão de negócios. Recomenda-se cuidadosa compreensão dos mesmos nas empresas com as quais será realizada a combinação, buscando-se identificar o desenho de cada um deles e as razões que levaram ao sucesso dos produtos desejados. Diferenças significativas nas atividades de pesquisa, de manufatura ou mesmo de comercialização podem criar obstáculos intransponíveis para a futura integração entre as empresas.

Por fim, na expansão através de atividades de pesquisa e desenvolvimento, Bower (2001) identifica que as empresas utilizam esta abordagem para construir posicionamentos rápidos em determinados mercados. São citados casos clássicos deste tipo de aquisição na indústria de tecnologia da informação, especificamente o caso da Cisco e da Microsoft, visto que ambas substituíram as atividades de pesquisa interna por aquisições, implementadas de maneira bastante ágil, visado fornecer respostas eficazes às pressões ambientais de concorrência. $\mathrm{O}$ 
sucesso deste setor, entretanto, é comparado às dificuldades enfrentadas pelas empresas farmacêuticas, cujas aquisições não apresentaram os mesmos resultados positivos. A justificativa para esta diferença foi apresentada pelo Autor como relacionada diretamente à maior facilidade de integração entre as tecnologias no setor de informática. Outro fator pode estar relacionado ao longo ciclo de pesquisa e desenvolvimento de produtos característico do setor farmacêutico.

De maneira análoga, Marks \& Mirvis (1998) observam a necessidade de expansão como elemento alavancador das ocorrências de integração entre empresas. Além disso, os Autores utilizam denominações distintas para os três tipos que compõem esta categoria. Dessa forma, as estratégias de expansão do território geográfico, portfolio de produtos e pesquisa e desenvolvimento são mencionadas por estes Autores como relacionadas respectivamente à globalização, diversificação de produtos e serviços, e acesso a novas tecnologias.

É importante salientar, entretanto, que o modelo de categorização proposto por Marks \& Mirvis (1998) apresenta-se mais difuso do que o modelo de Bower (2001), demonstrando que não houve a preocupação em identificar razões estratégicas mutuamente excludentes e sim assinalar razões diversas para a realização das combinações entre empresas.

A estratégia de expansão também é trabalhada pelo grupo Strategor (1997), com a proposição das aquisições para a formação de conglomerados. Este tipo de estratégia, segundo o grupo, tem o objetivo de aprimorar o equilíbrio financeiro global da empresa e a sua implementação pode envolver todos os tipos identificados e relacionados à expansão: geografia, produtos e tecnologia. Através da expansão de territórios geográficos, podem ser aproveitadas especificidades locais gerando benefícios financeiros para os conglomerados. O mesmo raciocínio pode ser aplicado para a diversificação do portfolio de produtos, assim como para a aquisição de novas tecnologias, criando um escopo amplo para este tipo de estratégia na combinação entre as empresas. 


\subsubsection{Integração vertical}

Este tipo de abordagem é discutido no referencial conceitual proposto por Marks \& Mirvis (1998), que ressalta a possibilidade de aquisição tanto de um fornecedor quando de um cliente, atuando de maneira complementar na cadeia de negócios da indústria. No caso do fornecedor, é possível aprimorar a disponibilidade de insumos ou mesmo diminuição dos custos relacionados à compra de matérias-primas. Ao expandir-se no outro lado da cadeia, as empresas podem obter ganhos na distribuição e na comercialização dos seus produtos, criando vantagens competitivas em relação aos seus concorrentes. Os Autores utilizam como exemplo ilustrativo o caso da aquisição da Capital Cities/ ABC pela Walt Disney, através da qual esta empresa criou um canal de distribuição para os seus programas de televisão e filmes produzidos.

O grupo Strategor (1997) identifica argumentos favoráveis a este tipo de estratégia, relacionados à economia de integração técnica obtida através da estruturação de cadeias eficientes de logística e da melhor eficiência na abordagem ao mercado, diante da aquisição de canais de distribuição. O grupo salienta, entretanto, o risco deste tipo de escolha e a necessidade de análise cuidadosa das leis que regulam as regras de concorrência, pois uma empresa integrada pode prejudicar os seus competidores utilizando políticas agressivas de preços e ter suas atividades penalizadas diante de tal situação.

Os critérios para a tomada de decisão, orientando a empresa para este tipo de estratégia, têm sua base no referencial conceitual dos custos de transação formulado por Coase (1988). Sua proposição formula críticas à teoria econômica neoclássica, na qual a firma apresenta-se como um conjunto ordenado e factível de planos de produção que, dentro da racionalidade econômica, tem como objetivo a maximização do lucro, através de operações de compra e venda de insumos e produtos. Inserida em um mercado com livre disponibilidade de informação, suas funções devem maximizar o bem-estar de seu dono e dos demais agentes envolvidos. Além disso, o Autor identifica que os critérios de desempenho das organizações são focados predominantemente em elementos do contexto externo da firma.

A identificação da existência de custos de transação proposta por Coase (1988) leva à emergência da análise aprofundada das transações, transformando a firma em um nexo de 
contratos (Demsetz, 1995). Uma das razões apontadas para a existência das firmas, de acordo com Williamsom (1975), corresponde à busca pela eficiência dos custos de transação. Ao analisar os custos de realizar transações com o mercado, qualquer alternativa de organização interna que possa levar ao mesmo resultado, porém com um custo menor, estimula a adoção de movimentos de integração vertical, transferindo a realização das transações para o interior da firma. A existência desta nova configuração de transações aumenta a complexidade do ambiente interno da organização, através da ampliação do seu quadro de profissionais, estabelecimento de novas relações internas e modificações no processo decisório, características presentes nos processos de combinação entre as empresas.

\subsubsection{Redefinição de fronteiras na indústria}

As categorias apresentadas até aqui envolvem mudanças no relacionamento entre distintos participantes da mesma indústria. Neste último tipo, identificado nos estudos de Bower (2001), ocorre a reconfiguração entre indústrias nas quais as suas fronteiras encontram-se indefinidas ou tendem a desaparecer. Nestes casos, o desafio gerencial torna-se significativamente maior uma vez que, além da efetividade da negociação do acordo e da integração, o sucesso dependerá de apostas corretas nas possíveis mudanças de delimitação destas fronteiras. Além disso, é importante destacar que os fatores de sucesso da operação não estão restritos à eficácia da integração entre as empresas, mas sim na capacidade de estabelecimento de posicionamento consistente e compatível com a delimitação característica da nova indústria.

Bower (2001) identifica dois casos clássicos deste tipo de combinação. O primeiro corresponde à compra da NCR pela AT\&T, a partir da aposta de que as indústrias de computadores e telecomunicações seriam convergentes. O outro caso citado é a Viacom, que se posicionou como uma provedora global de entretenimento com a integração do seu estúdio cinematográfico (Paramount), TV a cabo (MTV) e distribuidor de vídeo (Blockbuster).

Miles \& Snow (1978) apresentam a importância do enfoque financeiro nas decisões que balizam as operações desta natureza. Os Autores constroem o seu raciocínio salientando que todas as abordagens que levam às combinações empresariais criam a necessidade de tomada 
de decisões que envolvem elementos de natureza estratégica, de estrutura e de processos. Os Autores destacam, entretanto, que nos casos de transações intersetoriais ou formação de conglomerados, estas decisões tornam-se mais complexas e podem naturalmente levar ao fracasso se não houver um foco de atenção predominante nas sinergias de caráter financeiro. De acordo com os seus estudos, decisões que percam o foco essencialmente financeiro como, por exemplo, rotação de gerentes entre diferentes divisões da nova organização ligadas apenas ao desenvolvimento gerencial, ou mesmo criação de grupos centralizados de pesquisa e desenvolvimento apenas em busca das vantagens da inovação, podem ser extremamente arriscadas diante da complexidade relacionada às combinações desta natureza. Deve haver, portanto, uma ponderação bastante cuidadosa entre os benefícios de longo prazo e a captura de sinergias financeiras no curto prazo viabilizando resultados imediatos para as organizações.

\subsection{Análise da efetividade destas operações no momento atual}

As combinações entre empresas, segundo Geisst (2003), foram inseridas no início do século dentro de um movimento denominado “capitalismo financeiro”. Apesar deste termo não ser mais utilizado atualmente, o Autor destaca que as forças que impulsionam este tipo de operação permanecem semelhantes, ou seja, o potencial valor gerado às empresas participantes dos acordos de aquisições e fusões. No início do século, este valor era denominado “watered stocks” ou, para alguns mais céticos em relação ao fenômeno emergente, utilizava-se simplesmente o termo alquimia. Atualmente, analistas e executivos denominam de “sinergia” o valor adicional gerado para as organizações, partindo-se da premissa de que as companhias possuem maior valor juntas do que atuando separadamente.

Ao dedicar seu livro às “Armadilhas da Sinergia”, Sirower (1999) busca demonstrar que apesar de várias décadas de experiência e bilhões de dólares gastos com trabalhos de consultoria e pesquisa, as decisões de combinação empresarial continuam destruindo valor para os acionistas. As empresas normalmente pagam valores elevados para efetivar a sua intenção de adquirir outras empresas e raramente obtêm os resultados esperados. O Autor, de maneira análoga a Geisst (2003), define o conceito de sinergia como o incremento no desempenho organizacional em relação aos resultados esperados pelas companhias caso permanecessem operando isoladamente. 
Gaughan (1996) utiliza um parâmetro de análise semelhante, ressaltando que o indicador de sucesso de aquisições e fusões corresponde à capacidade do modelo de gestão resultante da operação em gerar mais valor ao acionista quando comparado à configuração organizacional anterior.

Várias publicações e empresas de consultoria têm promovido reflexões sobre a efetividade das operações de combinações entre empresas. A listagem abaixo destaca algumas destas publicações, demonstrando os baixos indicadores de sucesso verificados:

- Estudo realizado por Zweib (1995), analisando acordos avaliados em US\$ 500 milhões ou mais, demonstrou que 50\% das operações destruíram o valor das ações, 30\% tiveram um impacto mínimo e $17 \%$ adicionaram valor ao retorno para os acionistas;

- Até 75\% das fusões européias, segundo Harper \& Cormeraie em 1995 (in Marks \& Mirvis, 1998), terminam em fracasso;

- A publicação de Marks \& Mirvis (1998), após a análise de diversos estudos e elaboração de amplo referencial teórico, sintetiza que pelo menos $75 \%$ das operações de fusões terminam em fracasso;

- De acordo com a apostila do programa de Aquisições e Fusões da American Management Association publicada em 1997, aproximadamente 15\% das aquisições e fusões nos Estados Unidos atingem os objetivos financeiros estabelecidos;

- Estudo da empresa de consultoria A.T.Kearney com 115 transações globais, realizado no período entre 1998 e 1999 e publicado por Habeck, Kröger \& Träm (2000), revela que 58\% destas operações falharam em alcançar os valores estabelecidos como metas pelo grupo de liderança das empresas ao efetivar a comunicação do acordo;

- Síntese publicada em 2002 pela consultoria Deloitte Touche Tohmatsu relata que as pesquisas realizadas por esta empresa nos últimos 10 anos demonstram que $50 \%$ das aquisições e fusões mundiais não foram bem sucedidas, diminuindo o valor para o acionista. Segundo esta mesma pesquisa, apenas $17 \%$ das operações analisadas criaram valor significativo;

- Artigo publicado por Selden \& Colvin (2003) apresenta que entre 70 e $80 \%$ das operações de aquisições terminam em fracasso. Isto quer dizer, segundo os Autores, que as operações mencionadas não geraram riqueza para os acionistas das empresas compradoras. 
Independente da data de publicação e do rigor acadêmico dos estudos mencionados, o ponto relevante a ser considerado corresponde à dificuldade de obtenção de indicadores de desempenho positivos nas combinações entre empresas.

A verificação dos indicadores pouco satisfatórios apresentados gera significativa preocupação nos autores relacionados ao tema, que fazem nas suas publicações uma ampla exploração das razões que podem levar ao fracasso destas operações (Haspeslagh \& Jemison, 1991; Pritchet, 1997; Marks \& Mirvis, 1998; Sirower, 1999; Wasserstein, 2000; Habeck, Kröger \& Träm, 2000; Selden \& Colvin, 2003). As razões apresentadas por estes autores são bastante diversas, abrangendo elementos relacionados à baixa consistência da estratégia orientadora da operação; miopia na análise financeira para proposição do modelo de negócios e captura de sinergias; falhas na implementação de due dilligences e grupos de trabalho para a formação da nova empresa; dissonância entre padrões culturais distintos; baixa adesão e comprometimento das pessoas com a organização resultante do processo de combinação; e, perda de profissionais talentosos para a concorrência diante da insegurança característica deste tipo de processo de mudança.

A identificação destes desafios e razões que podem levar ao fracasso das operações reforça a complexidade das combinações empresariais e ressalta a relevância do aprimoramento do conhecimento disponível sobre este tipo de fenômeno. Para a formulação do modelo de gestão da mudança proposto na delimitação do problema de investigação deste trabalho, torna-se importante compreender as etapas que devem ser implementadas pelas organizações para viabilizar este tipo de transação.

\subsection{Etapas do processo de combinação entre empresas}

Os trabalhos que apresentam referências sobre estas etapas têm enfoque bastante pragmático, decorrente da pesquisa e experiência dos autores em organizações que optaram pelas aquisições e fusões para a implementação das suas estratégias de crescimento. Entre os autores consultados, três publicações detalham com precisão etapas concretas para a efetivação de operações desta natureza - Sirower (1999), Marks \& Mirvis (1998) e Galpin \& Herndon (2000). 
Marks \& Mirvis (1998) identificam três etapas nos processos de aquisições e fusões entre empresas - pré-combinação, combinação e pós-combinação - cada uma delas apresentando desafios distintos e, portanto, demandando abordagens de gestão com características específicas.

Na pré-combinação, o enfoque predominante é tipicamente financeiro e voltado para os resultados a serem alcançados com a operação. Os Autores recomendam que, neste momento do processo, haja ênfase em elementos estratégicos dos negócios, possibilitando análise ampla de variáveis que podem ter impacto significativo nos futuros resultados da empresa originária da combinação.

Os potenciais problemas emergentes nesta etapa, segundo Marks \& Mirvis (1998) correspondem à baixa clareza das estratégias de negócios ou mesmo indefinição do core business da empresa em formação. Outros elementos preocupantes neste momento estão relacionados à pressão para a realização do acordo, levando à inconsistência de informações ou mesmo decisões erradas no processo de due dilligence. Objetivos ou sinergias mal estimados, assim como retornos e resultados esperados com baixa precisão, são exemplos típicos de elementos que podem levar ao fracasso das operações neste momento da transação.

A segunda etapa inicia-se com o fechamento do acordo. Uma vez que as organizações passam a ter uma convivência mais próxima, as variáveis políticas tornam-se bastante marcantes e influentes. Neste momento do processo, um fator crítico de sucesso, na opinião dos Autores, corresponde à ênfase no planejamento, criando as bases para que a comunicação e o gerenciamento da transição sejam bem sucedidos.

Os principais riscos desta etapa correspondem à discrepância entre os objetivos estabelecidos no início do processo e a realidade identificada pelos gestores responsáveis pela integração entre as empresas. Os profissionais de nível médio na estrutura passam a assumir papel ativo no processo de integração e, portanto, torna-se fundamental que as premissas estabelecidas no início do acordo, assim como os resultados a serem alcançados, estejam claros para os executivos diretamente envolvidos na integração entre as empresas. Além disso, a negação ou subestimação dos padrões culturais das empresas e elementos psicológicos das pessoas torna- 
se extremamente prejudicial ao processo de mudança, uma vez que a gestão assumirá um caráter predominantemente técnico em detrimento das importantes dimensões sociais.

A última fase destas operações proposta pelo modelo dos Autores - denominada póscombinação - é composta pela implementação das decisões tomadas nas etapas anteriores. Fazem parte destas decisões as variáveis relacionadas ao modelo organizacional, às políticas, às práticas de gestão e às pessoas. Os Autores apresentam alguns obstáculos característicos desta etapa, tais como a necessidade de uma implementação rápida e sustentada por recursos - humanos e financeiros - insuficientes. Além disso, a baixa preocupação com o desenvolvimento das equipes pode levar a obstáculos intransponíveis.

As dimensões culturais também se apresentam extremamente importantes na pós-combinação. Nesta etapa, Marks \& Mirvis (1998) identificam que os padrões desenvolvidos na etapa anterior são reforçados e passam a fazer parte da cultura da nova organização. A não realização de reflexões sobre a cultura desejada durante a etapa anterior, característica de uma postura passiva diante desta importante variável, leva ao que os Autores denominam de “cultura resultante como um default e não como um desenho planejado”. De maneira análoga à pouca preocupação com estas variáveis, outra postura bastante negativa para os futuros resultados da nova empresa corresponde à baixa atenção, e conseqüente perda de oportunidades, para promover o desenvolvimento organizacional da empresa resultante da combinação.

Sirower (1999) e Galpin \& Herndon (2000) apresentam as suas abordagens compostas por passos concretos, os quais devem ser seguidos para viabilizar a transação de aquisição ou fusão desejada. Estes Autores fazem uma leitura do mesmo fenômeno de combinação empresarial, porém o descrevem em diferentes etapas, aprofundando o foco da sua investigação nos momentos anteriores ao fechamento do acordo.

De acordo com a abordagem proposta por Galpin \& Herndon (2000), as combinações apresentam cinco etapas, denominadas como formulação, localização, investigação, negociação e integração. Sirower (1999) também faz um raciocínio seqüencial, porém composto por seis passos: definição estratégica, busca de aquisições potenciais, avaliação das potenciais empresas identificadas, análise financeira, negociação e integração pós-fusão. 
Apesar de características específicas em cada uma das propostas, é possível identificar uma série de semelhanças entre os trabalhos destes autores. O início do processo apresenta forte vínculo com a prática de planejamento estratégico da empresa. Neste momento, as organizações estabelecem objetivos concretos de negócios, bem como as suas estratégias de crescimento para o futuro. Estes elementos fornecem insumos relevantes para a etapa subseqüente, na qual devem ser identificadas empresas consideradas compatíveis com a intenção estratégica definida no início da reflexão.

Uma vez identificadas estas empresas compatíveis com as premissas da operação, inicia-se um trabalho de análise de informações, baseado em exercícios de due dilligence, visando levantar e refinar informações relevantes para a tomada de decisão que levará à efetivação da operação. Galpin \& Herndon (2000) destacam esta atividade na etapa denominada investigação e mencionam a necessidade de utilização de diversas áreas de expertise para a fundamentação do trabalho e posterior tomada de decisão. Sirower (1999), por outro lado, divide este momento do processo em duas etapas - avaliação das potenciais empresas identificadas e análise financeira - demonstrando a necessidade de analisar a compatibilidade das empresas prospectadas com a estratégia definida inicialmente. De acordo com o Autor, "uma mesma empresa target pode ter valores significativamente diferentes para distintas empresas compradoras” uma vez que as competências destas têm características específicas e, portanto, trarão diferentes oportunidades estratégicas e sinergias a serem capturadas. Além disso, o trabalho de Sirower (1999), focado na questão da sinergia das combinações empresariais, demonstra a necessidade de uma etapa específica para análise financeira que, de acordo com a sua abordagem, deve ser posterior à avaliação geral das empresas target, realizada na etapa anterior.

Os próximos passos do processo - negociação e integração - apresentam-se semelhantes nas abordagens propostas por Sirower (1999) e Galpin \& Herndon (2000). Ambas as publicações destacam a importância das expectativas e intenções das organizações participantes da operação no momento da negociação. A definição do preço a ser pago e das condições características da transação, portanto, configuram-se como as principais pontos a serem considerados neste momento do processo. 
O fechamento do acordo leva à etapa da integração, momento mais crítico do processo, segundo os Autores. Neste estágio, as organizações que realizaram a transação reúnem os seus esforços na implementação de um processo de transição e devem tomar uma série de decisões bastante relevantes entre as quais destaca-se a velocidade a ser implementada na condução da mudança, as estratégias de comunicação para os diversos stakeholders envolvidos e os instrumentos a serem utilizados para garantir uma gestão efetiva do processo.

A sistematização das etapas propostas pelos autores analisados, mantendo o enfoque específico de cada um deles, fornece insumos para a elaboração da primeira versão do modelo de gestão da mudança proposto neste trabalho. Esta versão, de caráter essencialmente teórico, tem como objetivo viabilizar a compreensão ampla de combinações empresariais. A consulta às referências bibliográficas utilizadas possilitou o detalhamento de cada uma das etapas propostas, com as atividades que devem ser desempenhadas para a efetivação da transação. 
Tabela 2: Primeira versão do modelo de gestão da mudança para combinações empresariais

\begin{tabular}{|c|c|c|c|c|}
\hline $\begin{array}{l}\text { Etapas da } \\
\text { combinação }\end{array}$ & \begin{tabular}{|l} 
Marks \& \\
Mirvis (1998)
\end{tabular} & $\begin{array}{l}\text { Sirower } \\
\text { (1999) }\end{array}$ & $\begin{array}{l}\text { Galpin \& } \\
\text { Herndon (2000) }\end{array}$ & Detalhamento das etapas \\
\hline $\begin{array}{l}\text { Planejamento } \\
\text { estratégico }\end{array}$ & \multirow{4}{*}{$\begin{array}{l}\text { Pré- } \\
\text { combinação }\end{array}$} & $\begin{array}{l}\text { Definição } \\
\text { estratégica }\end{array}$ & Formulação & $\begin{array}{l}\text { - Elaboração de cenários futuros para a organização e possíveis diretrizes } \\
\text { estratégicas a serem implementadas } \\
\text { - } \quad \begin{array}{l}\text { Identificação de gaps no modelo de negócios da empresa para a } \\
\text { efetivação das diretrizes estratégicas estabelecidas }\end{array}\end{array}$ \\
\hline $\begin{array}{l}\text { Prospecção de } \\
\text { oportunidades }\end{array}$ & & $\begin{array}{l}\text { Busca de } \\
\text { empresas } \\
\text { potenciais } \\
\text { para aquisição }\end{array}$ & Localização & $\begin{array}{l}\text { - Prospecção de oportunidades no mercado para suprimir os gaps } \\
\text { identificados na etapa de planejamento estratégico } \\
\text { - Estabelecimento de objetivos para potenciais combinações e } \\
\text { identificação de potenciais benefícios a serem obtidos com a transação }\end{array}$ \\
\hline $\begin{array}{l}\text { Avaliação de } \\
\text { oportunidades }\end{array}$ & & $\begin{array}{l}\text { Avaliação das } \\
\text { empresas } \\
\text { target } \\
\text { identificadas } \\
\text { Avaliação } \\
\text { financeira }\end{array}$ & Investigação & $\begin{array}{l}\text { - Atuação de diferentes áreas de expertise - área financeira, jurídica, RH } \\
\text { e comercial - para levantamento de informações nas empresas target } \\
\text { - } \quad \text { Detecção de riscos e análise da compatibilidade com o critério } \\
\text { estratégico definido inicialmente pela organização para a efetivação da } \\
\text { combinação } \\
\text { - Confirmação da decisão para a continuidade do processo }\end{array}$ \\
\hline $\begin{array}{l}\text { Negociação e } \\
\text { efetivação do } \\
\text { acordo }\end{array}$ & & Negociação & Negociação & 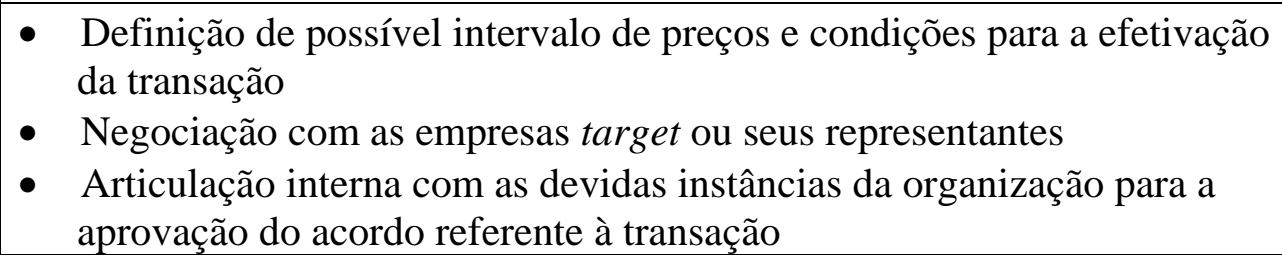 \\
\hline $\begin{array}{l}\text { Integração pós- } \\
\text { combinação }\end{array}$ & $\begin{array}{l}\text { Combinação } \\
\text { Pós- } \\
\text { combinação }\end{array}$ & $\begin{array}{l}\text { Integração } \\
\text { pós-fusão }\end{array}$ & Integração & $\begin{array}{l}\text { - } \quad \text { Estabelecimento de time de integração } \\
\text { - } \quad \text { elaboração e implementação de plano para integração dos negócios das } \\
\text { - } \quad \text { Integração de políticas, processos e instrumentos de gestão } \\
\text { - } \quad \text { Implementação de plano de comunicação }\end{array}$ \\
\hline
\end{tabular}


A utilização deste modelo teórico possibilita a identificação de dois momentos característicos das combinações empresariais. O primeiro corresponde ao processo de concepção da estratégia e tomada de decisão para a efetivação da operação. Na seqüência, o segundo momento engloba a gestão da integração entre as empresas para viabilizar a consecução da estratégia concebida e a transição ao novo modelo de negócios correspondente. Haspeslagh \& Jemison (1991) identificam estas duas fases das aquisições e fusões entre empresas e as denominam de processo decisório e integração entre as empresas.

No modelo de gestão da mudança apresentado na tabela anterior, o primeiro momento corresponde às fases iniciais de planejamento estratégico e termina com a negociação e efetivação do acordo enquanto que o segundo está presente na etapa de integração póscombinação.

Cada um destes momentos apresenta determinados desafios de gestão e riscos, resultando nas distintas razões para o fracasso das combinações empresariais apontadas pelos autores, as quais são exploradas na sequência.

\subsection{Causas de fracasso das operações de combinação empresarial}

O período da transação que ocorre entre as fases de identificação de oportunidades até a efetivação da transação tem como principal vulnerabilidade a baixa clareza ou inconsistência do conteúdo estratégico do negócio construído com a operação. Este tipo de problema normalmente se expressa no início do processo de mudança, quando são definidos os princípios norteadores da tomada de decisão que justifica a combinação e são selecionados parceiros para viabilizar o acordo de negócios. Marks \& Mirvis (1998) ressaltam que em muitas aquisições, os compradores não têm clareza das suas intenções em determinado mercado e tomam decisões de acordo com as tendências de ações implementadas pelos concorrentes. Diante da percepção de que se a empresa não caminhar em determinada direção estratégica não haverá condições de competir, várias aquisições ocorrem rapidamente e, conseqüentemente, sem um planejamento estruturado. Os Autores identificam esta problemática em setores como o financeiro, o de telecomunicações e o de entretenimento. 
Além disso, os erros na análise dos potenciais parceiros podem gerar resultados pouco satisfatórios para a nova configuração empresarial no futuro. Denominada por Wasserstein (2000) como inconsistência na estratégia de combinação, a escolha errada de parceiros pode comprometer o sucesso da operação e, conforme visto em muitos casos, desfazer o negócio causando impactos negativos para ambas as partes. Um exemplo típico deste tipo de problema ocorreu na Kodak. A compra da Sterling por esta empresa, visando aumentar a sua capacidade de obter aprovações em regulação de produtos da sua divisão de produtos farmacêuticos, foi desfeita cinco anos depois com a venda da Sterling, ao verificar o baixo nível de competências desta empresa para viabilizar os objetivos inicialmente perseguidos pela Kodak.

Sirower (1999) complementa este raciocínio demonstrando que determinadas condições estratégicas devem ser estabelecidas inicialmente para que a operação seja bem sucedida. A não realização de estudos sobre estas condições torna os líderes suscetíveis aos sedutores métodos de avaliação, normalmente utilizados por empresas de consultoria especializadas em aquisições e fusões.

Selden \& Colvin (2003) apresentam estas condições estratégicas sob uma perspectiva financeira, demonstrando preocupação quanto à miopia da análise dos dados contábeis e financeiros para a avaliação das combinações. De acordo com os Autores, o verdadeiro resultado de uma operação corresponde ao seu lucro econômico, ou seja, a lucratividade deduzida do custo do capital investido. O volume de capital investido nestas operações fica, com alta freqüência, bastante elevado em relação ao lucro operacional da nova empresa. O retorno sobre o capital investido, portanto, tende a diminuir significativamente, prejudicando o resultado da operação resultante da aquisição ou fusão.

A tabela abaixo, elaborada pelos Autores, demonstra com clareza esta situação, salientando dois momentos de uma mesma empresa: antes e após a realização de uma aquisição. O aumento do capital investido na operação gera impactos expressivos sobre o indicador retorno sobre o capital investido, sem necessariamente gerar benefícios ao lucro operacional. 
Tabela 3: Exemplo de resultado em uma aquisição: antes e depois

\begin{tabular}{|l|c|c|}
\hline & Antes da aquisição & Depois da aquisição \\
\hline Receita & 1.000 & 1.000 \\
Despesas & 900 & 900 \\
Lucro operacional líquido depois & 100 & 100 \\
dos impostos & & $3.000^{*}$ \\
Capital investido & 500 & $3,3 \%$ \\
Retorno sobre capital investido & $20 \%$ & $10 \%$ \\
Custo do capital & $10 \%$ & -200 \\
Lucro econômico & 50 & 2.000 \\
Valor de mercado/valor & 2.000 & -1.000 \\
intrínseco & 1.500 & \\
Valor gerado para acionista & & \\
*Valor de mercado de US\$ $2.000+50 \%$ de prêmio de controle & \\
Valores em US\$ milhões & & \\
\multicolumn{2}{l}{}
\end{tabular}

Fonte: Selden \& Colvin (2003)

Além disso, segundo os Autores, a necessidade de melhoria dos resultados leva à busca incessante por sinergias potenciais com o objetivo de reduzir os custos de operação da organização. Estas sinergias, entretanto, atenuam parcialmente o efeito da elevação do capital investido. Vale a pena frisar também que a busca inconsistente por sinergias potenciais pode gerar cortes em atividades e processos estratégicos e causando prejuízos irreparáveis ao resultado futuro da organização.

É importante ressaltar ainda as dificuldades de mensuração da efetividade destas operações utilizando apenas o enfoque econômico. Gaughan (1996) elabora este raciocínio questionando a dimensão temporal para a análise dos resultados das aquisições e fusões. Segundo o Autor, operações com esta magnitude não podem ser avaliadas de acordo com a possibilidade imediata de ganhos econômicos. Elas devem constituir-se como uma alternativa estratégica para futura geração de valor ao acionista, com resultados mensurados e analisados no longo prazo.

Sirower (1999) apresenta outro elemento importante relacionado à análise financeira. De acordo com o Autor, uma operação de combinação sempre consiste na aquisição ou compartilhamento de ativos e tecnologias. A decisão pela efetivação do acordo leva, portanto, ao pagamento de um valor adicional em relação à aplicação isolada destes ativos e tecnologias. Este adicional refere-se à sinergia potencial, ou seja, ao incremento de desempenho esperado com a operação. O Autor utiliza a “equação $2+2=5$ ” para expressar este 
conceito e posiciona claramente o perigo e os riscos inerentes a esta definição puramente matemática.

Sirower (1999) continua sua argumentação demonstrando que o grande vetor do fracasso associado às fusões e aquisições corresponde à falha na definição desta sinergia potencial e o seu impacto na melhoria das vantagens competitivas da organização resultante, comparada às empresas anteriores à efetivação da transação.

Uma razão de natureza distinta é mencionada por Bazerman (2004). Ao propor enfoque descritivo para o processo decisório de indivíduos e grupos, o Autor apresenta o conceito de escalada de comprometimento como um dos fatores de fracasso das aquisições entre empresas. Diante da tomada de decisão inicial de adquirir determinada organização, diferentes empresas podem travar uma disputa entre si pelo direito de compra. Esta escalada, identificada pelo Autor, justifica-se pela percepção de perda desenvolvida pela empresa caso a organização a ser adquirida seja incorporada por um concorrente, causando prejuízos em market share ou detenção de determinada tecnologia. A disputa entre estas empresas concorrentes entre si acaba configurando-se como um leilão e, conseqüentemente, gera uma inflação no valor de venda. O ganho obtido com esta operação, portanto, transfere-se diretamente para o vendedor, causando prejuízos significativos para a organização compradora.

O segundo momento característico dsa transações de combinação, conforme apresentado anteriormente, corresponde ao processo de integração entre as empresas participantes dos acordos, viabilizando a implementação da estratégia e a configuração do modelo de negócios definidos nas etapas anteriores.

Na opinião dos autores, são pouco significativos os esforços da liderança das empresas na elaboração e implementação de uma abordagem de gestão de mudança compatível com as estratégias e premissas que fundamentaram a realização da operação. Pritchet (1997) apresenta um estudo no qual apenas $20 \%$ das organizações que planejam aquisições consideram uma estratégia de longo prazo para integração entre as empresas antes de efetivar a compra planejada. 
Habeck, Kröger \& Träm (2000), em uma linha de raciocínio semelhante, demonstram a importância da integração ao apresentarem um estudo da empresa de consultoria A.T.Kearney, no qual identificam que a integração pós fusão é a principal responsável pelo risco de fracasso destas operações. O quadro abaixo expressa os resultados de uma das perguntas da referida pesquisa.

\section{Gráfico 5: Resultados da pesquisa conduzida pela A. T. Kearney}

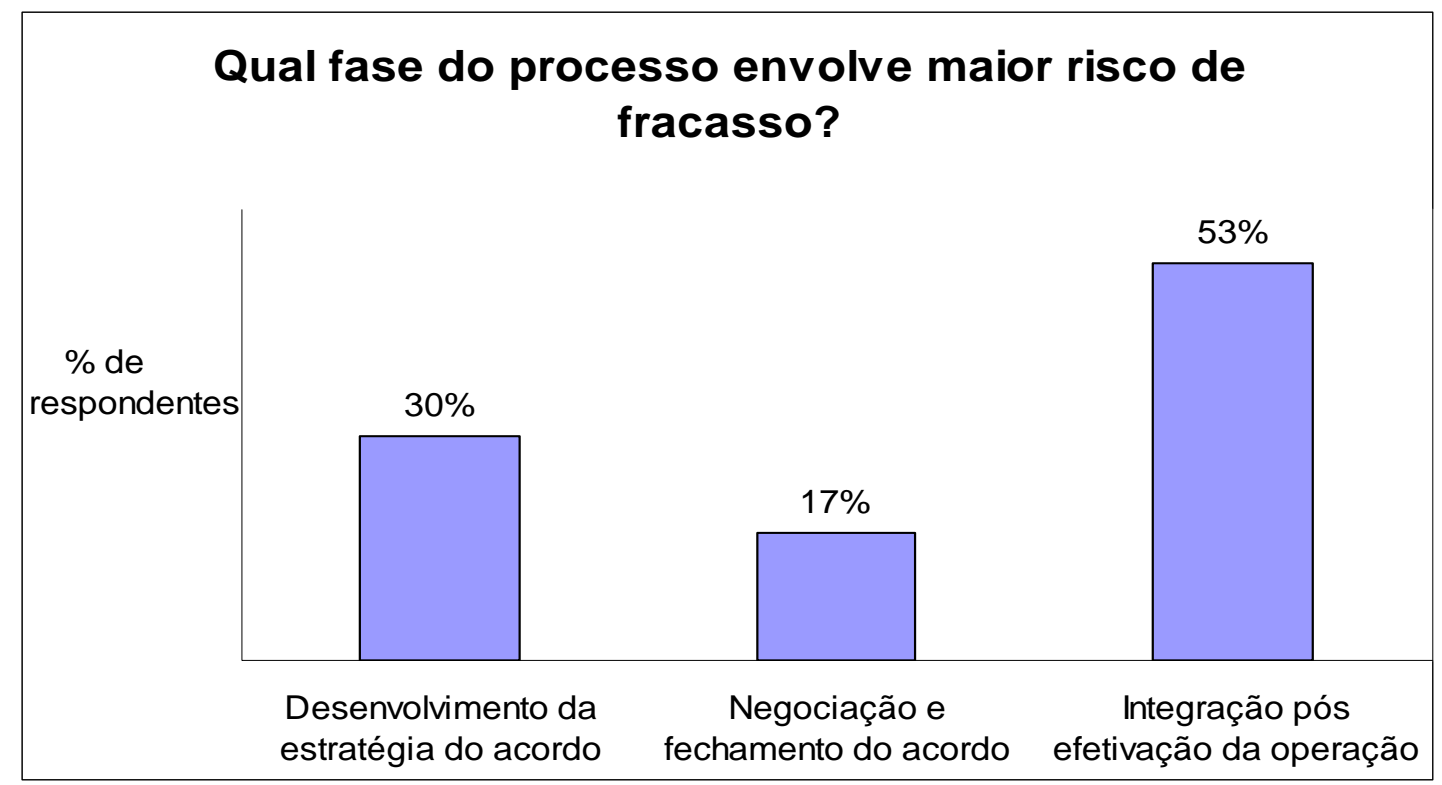

Fonte: Habeck, Kröger \& Träm (2000)

Sirower (1999) demonstra sua preocupação com este item ao apresentar um estudo do Boston Consulting Group o qual aponta que, nos processos de planejamento de aquisições, oito em cada dez empresas não chegaram a considerar como a operação da companhia adquirida deveria ser integrada ao seu modelo organizacional após a efetivação do acordo.

A predominância de trabalhos de natureza consultiva para ilustrar os riscos relacionados à integração entre as empresas demonstra a carência de referências conceituais, estruturadas com a profundidade necessária para levar à compreensão da natureza e da dinâmica desta etapa das combinações empresariais. Torna-se importante, portanto, complementar o referencial teórico deste trabalho com a reflexão sobre a questão da mudança nas organizações e os seus desdobramentos nas operações de aquisições e fusões. 


\section{CAPÍTULO 2: A MUDANÇA ORGANIZACIONAL COMO DESAFIO DE GESTÃO}

\subsection{Evolução do conceito de mudança}

A primeira expressão da mudança na tradição ocidental aparece nos trabalhos do filósofo présocrático Parmênides (século VI a.C.). A concepção do Uno de Parmênides busca demonstrar que o real deve ser imperecível, perfeito e imóvel, contrapondo-se às aparências relativas das coisas. Apesar da sua posição de que mudança e diversidade seriam apenas ilusões dos sentidos, seu legado apresenta a oposição entre o mundo mutável e o imutável, iniciando a reflexão sobre mudança na filosofia. De acordo com Bréhier (in Máttar, 1997), este pensador fez uma oposição definitiva da razão e verdade à percepção e opinião, sendo apontado por Aristóteles como o fundador da lógica, uma vez que construiu seu pensamento sobre os princípios da identidade e da contradição.

O pressuposto da mudança como um elemento constante aparece posteriormente com Heráclito de Éfeso (século V a.C.), considerado o primeiro pensador a expressar a natureza do mundo como um processo de mudança e transformação contínua. Heráclito é conhecido pelas suas idéias de fluxo, expressa na sua famosa afirmação de que é impossível entrar duas vezes no mesmo rio visto que as águas estão sempre fluindo. Sua doutrina, segundo Blackburn (1994), foi complementada pelo seu discípulo Crátilo (século V a.C.), que fundamentou a realidade como algo completamente particular. Ele fez contribuições à figura proposta por Heráclito apresentando que não é possível entrar nenhuma vez na água do mesmo rio, pois ele está em permanente mudança e já não existe mais mesmo quando alguém entra neste rio pela primeira vez.

Ao refletir sobre este referencial conceitual nas organizações, é interessante verificar que a preocupação com a mudança aparece bastante restrita no nascimento da teoria de administração. Apesar da dificuldade de delimitação do seu nascimento ${ }^{3}$, considera-se para fins deste trabalho a Escola de Administração Científica, no começo do século XX, como o início da concepção teórica da Administração como campo do conhecimento científico humano. Neste momento, o conceito de mudança possuía um caráter meramente corretivo, 
visando sanar as deficiências do processo produtivo e garantir a continuidade dos padrões de desempenho estabelecidos. Tornava-se necessário um controle efetivo das variáveis de tempo e espaço, com o objetivo de estabelecer as condições necessárias para viabilizar a produção da então recente manufatura em larga escala. Nesse quadro, a teoria administrativa tinha o objetivo de criar as condições para obter o controle sobre as relações entre as pessoas no ambiente de trabalho e destas com o processo produtivo, alcançando os padrões de produção e de qualidade necessários para atender as demandas do mercado.

A evolução da teoria administrativa, com a inserção da dimensão comportamental característica da Escola de Relações Humanas, trouxe elementos importantes sobre a atuação das pessoas, contribuindo para a compreensão e percepção da sua relevância para o alcance dos resultados econômicos esperados do processo de produzir e comercializar mercadorias. Posteriormente, o desenvolvimento da teoria geral de sistemas, na qual as organizações passam a ser caracterizadas como sistemas abertos em constante interação com o ambiente, evidenciou que a mudança organizacional era essencial para garantir a adaptação das empresas às variáveis externas, constituindo-se em um modo de introduzir aprimoramento incremental à gestão do capital humano e das organizações complexas.

Esta evolução foi reforçada pela introdução da perspectiva sociotécnica, que promoveu uma crítica às abordagens essencialmente mecanicistas do trabalho das pessoas no âmbito das organizações. Desenvolvida na década de 60 na Europa, esta perspectiva buscou um equilíbrio entre os recursos e as definições técnicas, até então predominantes, com a dimensão social dos grupos de trabalhadores, ressaltando a necessidade de aprimoramento da sua qualificação, das habilidades de negociação e tomada de decisão.

É importante frisar também a teoria de desenvolvimento organizacional, que destacou vários teóricos como Warren Bennis, Edgard Schein e Chris Argyris, cujas obras continuam em destaque até os dias de hoje (Motta, 1991). A compreensão da estrutura e do funcionamento de grupos sociais, característica desta escola, ressaltou a relevância da mudança organizacional, caracterizando-a como elemento essencial para o desenvolvimento das equipes. Além disso, esta escola promoveu uma associação da noção de mudança ao conceito

\footnotetext{
${ }^{3}$ São estabelecidas relações entre a teoria administrativa e diversos momentos da história da humanidade como, por exemplo, papiros do Egito na qual verifica-se a importância dada à organização e administração, registros da administração pública na Roma antiga e autores que elaboraram reflexões sobre a guerra como Carl Von Clausewitz (1780-1831).
} 
de desenvolvimento removendo, gradativamente, o teor negativo de crise e conflito que o mesmo carregava em sua origem (Fischer, 2002).

Sua contribuição, entretanto, continuou restrita à detecção e correção de problemas isolados identificados (Argyris, 1992), ou mesmo focada na melhoria do relacionamento entre os indivíduos pertencentes aos grupos de trabalho. Outra crítica apresentada relaciona-se ao seu enfoque predominantemente terapêutico e centrado em problemáticas individuais, em detrimento do foco em objetivos organizacionais e no incremento dos padrões de desempenho das pessoas, dos grupos e, portanto, das organizações.

\subsection{Uma nova concepção: o processo de mudança}

Apesar da evolução da teoria administrativa, a visão prevalente da mudança ainda restringiuse a fenômenos pontuais e esporádicos. Fischer (2002) ressalta que esta concepção era coerente com o paradigma da estabilidade, que preconizava a manutenção e o controle dos procedimentos gerenciais e para o qual a gestão da mudança aparece como um "mal necessário”, assumido apenas para assegurar o controle sobre processos organizacionais e a atuação das pessoas evitando desestabilizar o desempenho organizacional.

O aumento da relevância das pressões ambientais tais como a globalização, o acirramento da concorrência e a necessidade de aprimoramento dos indicadores de desempenho organizacional, demonstrou a restrição do conceito de mudança como uma variável tópica e pontual. A percepção de necessidades de intervenção e desenvolvimento mais amplo das organizações encontrou respostas com a proposição do fenômeno da mudança de larga escala, definido por Mohrmann et allii (1991) como a mudança duradoura no caráter da organização a qual impacta significativamente a sua performance. Os Autores utilizam dois elementos para definir o caráter da organização: o design, que inclui o conjunto de estratégias, estrutura, política, tecnologia e demais elementos formais da organização; e, o processo, composto pelo comportamento, energia interna e fluxo de informações existente na organização.

É interessante observar também a relação estabelecida por Mohrmann et allii (1991) entre a mudança organizacional e a revolução no desempenho das empresas. Para isso, os Autores 
utilizam diversos exemplos de empresas que modificaram as suas estratégias, modelos de gestão de negócios e padrões de lucratividade. São mencionados casos de empresas que trocaram objetivos de curto prazo para buscar o aumento de market share global. Outras empresas passaram a estabelecer relações de longo prazo com seus clientes, aprimorando os padrões de relacionamento em detrimento da margem de contribuição imediata. Os Autores identificam também empresas que modificaram os seus padrões de oferta, migrando de produtos para soluções e necessitaram utilizar, de maneira mais expressiva, ativos intangíveis como o capital de clientes e capacidade de inovação para a obtenção de vantagens competitivas.

O conceito de mudança de larga escala mostrou-se apropriado para explicar os impactos significativos que a mudança organizacional pode gerar nos resultados das organizações. tornando fundamental ampliar a discussão sobre a gestão deste fenômeno, conceituando-o com idéias mais abrangentes, bem como com tecnologia de gestão composta por instrumentos específicos e mais potentes para lidar com as suas características e complexidade. Um estudo importante nesta direção foi desenvolvido por Pettigrew \& Wipp (1991) em organizações de quatro setores produtivos ingleses: o automobilístico, o de produção de livros, o dos bancos comerciais e o das companhias de seguros de vida. Em sua análise, os Autores buscam demonstrar a relação entre o desempenho organizacional dessas empresas e a capacidade de adaptação de suas estratégias e dos seus modelos de gestão às pressões advindas do ambiente em que estão inseridas.

Pettigrew \& Wipp (1991) identificaram um padrão emergente para a gestão da mudança nas organizações relacionada ao seu ambiente competitivo e, através do seu trabalho, reforçaram duas dimensões de análise. Em primeiro lugar, a compreensão das forças competitivas da empresa deve ser realizada em três níveis, cada um deles com características e indicadores específicos: a firma com as suas respectivas estratégias e capacidade para mudança; o setor com sua estrutura de mercado específica, nível de maturidade da indústria e capacidade de estabelecer redes de relacionamento comercial; e, o ambiente macroeconômico com sua estrutura de custos, taxas de conversão monetária e modelo de relacionamento interorganizacional. A segunda dimensão de análise estabelece uma linha temporal e coloca a mudança como um processo contínuo que ocorre em contextos definidos. Significa dizer que é impossível compreender estas mudanças como elementos episódicos e separados das 
circunstâncias históricas das quais emergiram e para as quais são, concomitantemente, influenciadoras e influenciadas.

A combinação destas duas dimensões de análise ressalta a importância de um processo analítico apurado uma vez que, de acordo com Pettigrew \& Wipp (1991), as mudanças estabelecidas pelas empresas não se movem em uma direção linear e direta, ou mesmo através de uma seqüência de fases claramente perceptível. Os Autores ressaltam também a importância de que a concepção estratégica de mudança combine a objetividade das informações coletadas e passíveis de sistematização por parte dos executivos com a apreensão cognitiva das dimensões políticas que atuam, simultaneamente, dentro e fora da organização.

Nessa mesma linha de raciocínio, Fischer (2002) salienta a importância da modelagem do processo de transformação organizacional acrescentando dois elementos complementares para compreender e gerenciar o constante desenvolvimento das empresas. Para a Autora, a transformação deve ser gerenciada em seus aspectos objetivos, os quais estão relacionados a elementos técnicos e administrativos da estrutura e do modelo de gestão, mas também em seus aspectos intangíveis como os padrões culturais prevalentes e a dinâmica das relações de poder que constituem o tecido da organização.

O desenvolvimento das organizações também está diretamente ligado à questão da aprendizagem e do desenvolvimento de competências. Fleury \& Fleury (2000) relacionam esta discussão às mudanças ambientais externas, dentre as quais destacam os movimentos de globalização financeira, comercial e produtiva, assim como a necessidade de elevação dos patamares de competitividade empresarial.

A demanda crescente por uma visão estratégica consistente e um posicionamento efetivo neste cenário internacional, segundo os Autores, cria desafios para os modelos tradicionais de gestão de pessoas. Elaborados de acordo com os princípios do taylorismo-fordismo, estes modelos não fornecem respostas adequadas para a nova realidade uma vez que colocam o capital humano como um elemento relativamente pouco importante no processo produtivo. Seu foco na especialização, na centralização da decisão e na busca contínua pela eficiência valoriza os cargos e as funções em detrimento dos perfis de competências das pessoas. 
Ao resgatar o histórico do conceito de competências, Fleury \& Fleury (2000) identificam que a sua referência principal continua atrelada às atividades e tarefas prescritas nos cargos. Ao abandonar, em virtude do seu obsoletismo, o paradigma da estabilidade e do controle da gestão organizacional, a competência deve extrapolar o conceito de qualificação e sua associação com cargos e posições rigidamente estruturados.

Diante disto, os Autores propõem que o conceito de competência seja associado a um saber agir e mobilizar recursos, assim como integrar e transferir conhecimentos e habilidades no contexto profissional, agregando valor social ao indivíduo e econômico à organização. Dessa forma, a competência de um indivíduo não se restringe a conhecimentos e know how específicos e deve ser sempre contextualizada, gerando valor para a organização na qual o profissional se insere.

Dutra (2002), de maneira análoga, apresenta as competências pessoais e profissionais como um patrimônio de conhecimento das organizações, que lhes confere vantagens competitivas. O Autor propõe uma integração entre as pessoas e a organização colocando-as lado a lado e viabilizando um processo contínuo de desenvolvimento mútuo. As organizações criam condições para aprimorar a capacitação das pessoas, contribuindo diretamente para a sua empregabilidade. As pessoas, por sua vez, ao melhor qualificarem-se, transferem para a organização o seu aprendizado enriquecendo o patrimônio de conhecimento organizacional e, conseqüentemente, fortalecendo as suas vantagens competitivas.

\subsection{O desafio de gestão dos processos de mudança}

Os processos de mudança e transformação organizacional ainda encontram dificuldades inerentes à sua implementação e gestão. De acordo com pesquisa realizada pela empresa global de consultoria Bain \& Company (in Insead Quarterly, 2003), metade dos 223 executivos que participaram do levantamento de dados afirmaram que as suas empresas não possuem sistemas e habilidades suficientes para realizar uma gestão efetiva da mudança, conforme as necessidades impostas pelas pressões ambientais vigentes. 
Esta dificuldade apontada na pesquisa é reforçada pelo cientista da Universidade de Cambridge, Christopher Grey (in Bendassolli, 2003), que apresenta a existência de um "fetiche da mudança”, criticando as abordagens de que é possível planejar e controlar o curso, a intensidade e a direção da mesma. Para Grey, mesmo as organizações que implementarem processos de gestão da mudança efetivos, atendendo aos fatores críticos de sucesso apontados por teóricos e consultores organizacionais, podem alcançar resultados insatisfatórios uma vez que as relações sociais que compõem a mudança caracterizam-se pela natureza imprevisível e pouco suscetível ao controle gerencial.

Ainda assim, é importante destacar o trabalho de diversos autores que vêm tentando sistematizar conceitos e ferramentas para viabilizar uma implementação e gestão consistentes e eficaz das transformações organizacionais. Neste sentido, é possível identificar distintas linhas adotas pelos autores relacionados ao tema, enfocando elementos estratégicos, culturais, organizacionais e instrumentais da mudança.

Senge et allii (1994) utilizam um tripé composto por idéias orientadoras, elementos de infraestrutura organizacional e utilização de conceitos e técnicas de aprendizagem, para que as organizações assumam um processo de mudança contínua. O conceito de idéias orientadoras apresentado relaciona-se à visão, aos valores e à missão da empresa. Os Autores frisam a importância destas idéias refletirem o que os integrantes das organizações pretendem criar, caracterizando um "sonho" coletivo. O envolvimento das pessoas com estas idéias, possibilitando a identificação e construção de valores compartilhados, faz com que o aprendizado deixe de ser uma atividade obrigatória e passe a ser um objetivo comum desejado e perseguido por todos.

O reforço da aprendizagem ocorre, segundo os Autores, por meio de inovações na infraestrutura organizacional modificando as relações de autoridade, as estruturas de funcionamento, os fluxos de informação e a alocação de recursos. Para a sustentação deste processo, os profissionais devem ser capacitados com conceitos, teorias e ferramentas de aprendizagem, caracterizadas pelas cinco disciplinas propostas por Peter Senge (1990): domínio pessoal, explicitação de modelos mentais, visão compartilhada, aprendizagem em grupo e raciocínio sistêmico. 
Fleury \& Fleury (2000) reforçam a importância da aprendizagem na gestão do processo de transformação das organizações Os Autores ressaltam que é possível estabelecer uma dinâmica de aprendizagem através da retro-alimentação entre o desenvolvimento de competências e a implementação das estratégias organizacionais.

A compreensão desta dinâmica, segundo Fleury \& Fleury (1995), remete ao conceito de cultura organizacional, baseado em Schein (1986), que apresenta a aprendizagem nos momentos de criação dos valores e pressupostos básicos, assim como nos momentos de transmissão destes padrões culturais a novos membros que venham a integrar a comunidade organizacional. Os Autores ressaltam também a necessidade de analisar as relações de poder e as formas de interação entre os indivíduos, expressas através de símbolos e práticas organizacionais, para a compreensão do processo de aprendizagem e mudança nas empresas.

O desenvolvimento de competências nas organizações leva à reflexão do caminho existente entre a aprendizagem individual e a organizacional. Este processo, segundo Fleury \& Fleury (2000), ocorre em três níveis e inicia-se no indivíduo levando-se em consideração suas crenças, percepções, emoções e comportamentos. No nível do grupo, a aprendizagem passa a constituir um processo social e coletivo, estimulando interpretações e conhecimentos compartilhados entre as pessoas. No âmbito organizacional, o aprendizado torna-se institucionalizado e passa a caracterizar elementos organizacionais, tais como o conjunto de regras, as políticas e práticas gerenciais, o processo decisório e a comunicação interna, assim como os elementos simbólicos que permitem identificar as relações de poder e os padrões culturais prevalentes na empresa.

A aprendizagem, gerando novos conhecimentos e competências, pode ocorrer por meio de diversos processos. Fleury \& Fleury (2000) os dividem em pró-ativos e reativos, sendo os primeiros relacionados à experimentação e inovação. Já os segundos correspondem à resolução sistemática de problemas, à observação de experiências realizadas por outros e à contratação de novos profissionais. A disseminação dos novos conhecimentos, segundo os Autores, ocorre por meio da comunicação interna, de programas de treinamento, da rotação de pessoas e do estímulo ao trabalho em equipes diversas. 
É importante destacar também o trabalho realizado por Beer, Eisenstat \& Spector (1990), cujo objetivo foi analisar as falhas em processos de mudanças que, apesar de implementados por organizações, não conseguiram atingir os resultados esperados. Para os Autores, os esforços de mudança devem começar nos níveis hierárquicos mais baixos da estrutura organizacional, através da revisão de papéis, atribuições e responsabilidades dos profissionais, com o objetivo de solucionar problemas concretos. Esta constatação é apresentada pelos Autores ao identificar exemplos de empresas que não conseguiram viabilizar as mudanças planejadas por terem iniciado o processo com a revisão de elementos organizacionais corporativos tais como missão, valores e sistemas de gestão institucionais.

Beer, Eisenstat \& Spector (1990) propõem, a partir das suas reflexões, alguns elementos fundamentais para garantir a efetividade de um processo de mudança. O artigo apresentado pelos Autores demonstra, com bastante simplicidade e coerência, a aplicação destas etapas em contextos organizacionais, reforçando o cunho pragmático dos seus trabalhos. Dividida em etapas seqüenciais, a abordagem sugere que, em primeiro lugar, seja definido claramente um problema organizacional que demande uma solução objetiva. Em seguida, equipes do tipo forças-tarefa devem ser nomeadas para construção de uma nova visão compartilhada, diretamente relacionada à correção do problema detectado. Esta nova visão levará à redefinição de cargos, responsabilidades e, conseqüentemente, demonstrará a necessidade de desenvolvimento de novas habilidades e atitudes por parte dos profissionais envolvidos. Uma vez realizada a renovação na unidade de negócios ou departamento mencionado, os Autores consideram que esta mentalidade de revitalização será disseminada para outras áreas da empresa.

Esta passagem é crucial para o sucesso da mudança e não deve ser influenciada diretamente pela cúpula da organização. A necessidade de mudança deve partir do próprio departamento que sofreu a intervenção e, portanto, necessitará de novos padrões de serviços ou fornecimento levando, naturalmente, à necessidade de revisão de outros processos e instrumentos de áreas que lhe prestam serviços ou de seus clientes internos. Por fim, esta “contaminação” positiva criará bases sólidas para que o aprimoramento seja institucionalizado por meio de políticas, sistemas e estruturas formais. Os Autores acreditam, portanto, que haverá inserção e disseminação da renovação de maneira positiva e sem imposição por parte da liderança ou da cúpula administrativa da corporação. 
De maneira análoga à proposta de Beer, Eisenstat \& Spector (1990), Nutt \& Backoff (1997) identificam que a gestão da mudança torna-se efetiva quando liderada por um grupo de profissionais que, apesar de suportado pela cúpula da organização, deve estar dissociado desta. Este grupo, denominado de time de desenvolvimento, identifica oportunidades de melhoria radicais e incrementais para, gradativamente, disseminar a mentalidade de renovação através das demais instâncias da organização.

A importância das equipes também aparece na proposta metodológica de Fischer (2002). De acordo com a Autora, os grupos devem compor o núcleo gerador do modelo de gestão compartilhada para iniciar e conduzir a transformação organizacional. Este núcleo é composto por um grupo diretivo, um de mobilização e outro de integração de projetos, sendo que cada um deles possui papel e características distintas. O grupo diretivo responde pela condução geral do processo bem como pela tomada de decisões estratégicas, garantindo a legitimidade da transformação. O segundo - denominado mobilizador -atua como uma estrutura informal e responde pela disseminação do processo, garantindo que a mentalidade de renovação perpasse todas as áreas e níveis hierárquicos da organização. O grupo de integração de projetos, por sua vez, acompanha a implementação de ações através de equipes que foram designadas para a elaboração e implantação de melhorias definidas. Diante da diversidade de esforços de aprimoramento, este grupo de integração adquire papel relevante na identificação de contradições e oportunidades de sinergia entre estes esforços, garantindo a otimização dos recursos disponíveis.

Os grupos de mobilização e integração de projetos, propostos pela abordagem de Fischer (2002) constituem-se como uma estrutura informal da organização que gere o início do processo de transformação. A redefinição das relações de poder decorrente deste movimento, entretanto, leva à necessidade de uma reestruturação gerando modificações também na estrutura formal da organização. Vale a pena destacar que quanto mais intensas forem as mudanças geradas pelos grupos ao longo da transformação, maior será a necessidade de implementação de ajustes no desenho da organização formal.

A compreensão do funcionamento deste tipo de estrutura também remete ao trabalho de Cohen (1995), que faz uma excelente descrição das características, riscos e oportunidades das 
novas configurações de trabalho em equipe. No seu artigo, a Autora descreve o funcionamento das organizações paralelas e networks, que atuam como base das abordagens propostas pelos autores anteriores. Entre as diversas contribuições e pontos ressaltados pela Autora, vale a pena destacar que o grande risco deste tipo de formato corresponde à competição de recursos entre as organizações paralelas e informais com a estrutura formal da empresa. Estes recursos podem ser materiais, humanos, financeiros ou mesmo o tempo despendido com as atividades e tarefas.

Diante disto, torna-se evidente o papel da liderança que, comprometida com a renovação, deve gerenciar os potenciais conflitos de maneira que a transformação organizacional não seja interrompida ou prejudicada. Fischer (2002) ressalta este papel na atuação do grupo diretivo, responsável pela legitimidade política de todo o processo, bem como facilitando o processo de negociação e coalizão de forças de interesses nas definições relativas à alocação dos recursos disponíveis.

Dutra (2002; 2004) apresenta uma linha complementar à implementação e gestão da mudança, por meio do aprimoramento dos modelos de gestão de pessoas. O Autor apresenta elementos concretos deste modelo relacionados a três componentes principais: movimentação, desenvolvimento e valorização de pessoas.

O primeiro componente, segundo o Autor, reflete os movimentos efetuados pelas pessoas na empresa ou no mercado de trabalho. Ele é composto por processos e práticas relacionadas à captação, socialização, transferência, promoção, expatriação e recolocação de profissionais. No que diz respeito ao desenvolvimento dos indivíduos, as práticas e instrumentos predominantes são programas de capacitação, sistemas de administração de carreiras, plano sucessório e programas de avaliação de desempenho. Por fim, na categoria de valorização estão os sistemas de remuneração fixa e variável envolvendo premiações e participação nos resultados, assim como planos de benefícios adotados pelas empresas.

Cada um destes componentes apresenta instrumentos específicos e passíveis de implementação, contribuindo para o desenvolvimento das organizações. Segundo Dutra 
(2004), a sua utilização fornece importantes insumos para a compreensão da realidade organizacional e viabilização da intervenção sobre a mesma levando ao seu aprimoramento. Os instrumentos de gestão propostos criam bases sólidas e consistentes para a efetiva gestão dos processos de mudança e transformação organizacional. 


\section{CAPÍTULO 3: GESTÃO DA MUDANÇA NAS COMBINAÇÕES EMPRESARIAIS}

Os esforços para a sistematização de conceitos, ferramentas e instrumentos utilizados para a gestão de processos de mudança tornam-se bastante relevantes quando são analisados os casos de aquisições e fusões entre empresas. Diversos autores enfatizam os problemas criados pela baixa preocupação com a gestão de mudança organizacional nestas ocasiões, atribuindo aos líderes e dirigentes de empresas a responsabilidade por esta falta de visão estratégica na maioria dos processos de combinação ocorridos nas últimas décadas.

Wasserstein (2000) destaca três elementos para a gestão do processo de integração entre as empresas. Em primeiro lugar, o Autor identifica a importância da rapidez na efetivação das mudanças, de preferência nos primeiros seis meses, período no qual os gestores e os demais profissionais estão mais predispostos à experiência de transformação. Outro ponto relevante destacado corresponde à alocação dos executivos nas posições de comando através da utilização de critérios consistentes, garantindo um estilo de liderança forte, rápido e assertivo. É fundamental também que os executivos da operação sejam envolvidos desde cedo no processo, incluindo-os o mais rápido possível no desenvolvimento dos modelos de gestão estratégicos e operacionais da nova configuração empresarial.

Outros trabalhos enfatizam a importância da integração entre as empresas participantes da operação. Galpin \& Herndon (2000) demonstram que este tipo de preocupação não deve se restringir ao momento em que os profissionais da empresa começam a trabalhar juntos, mas sim desde o período em que se inicia a intenção de efetivar a operação. Segundo os Autores, a negligência no gerenciamento da mudança na etapa de due dilligence, em que se verifica a viabilidade do futuro negócio incluindo o mapeamento de riscos relacionados a fatores culturais, organizacionais e humanos, pode causar impactos significativamente negativos para a eficácia da combinação entre as empresas.

Uma abordagem voltada para a atuação e o comportamento das pessoas identifica que o afloramento das emoções e sentimentos característicos deste tipo de processo leva à proposição de possíveis síndromes que surgem ao longo do processo. Marks \& Mirvis (1998) 
buscam explicar de maneira estruturada estas síndromes, propondo três categorias de reações ao stress característico destas operações, conforme descreve o quadro a seguir:

\section{Quadro 2: Detalhamento da síndrome das combinações}

\section{Reações pessoais}

- Preocupação pessoal

- Identificação dos piores cenários

- Criação e disseminação de rumores

- Distração em relação ao desempenho no trabalho

- Reações psicossomáticas

\section{Reações culturais}

- Choque de culturas

- Nós versus eles

- Superior versus inferior

- Ataque e defesa

- Vencedores e perdedores

- Decisões através de combate entre as pessoas

\section{Reações organizacionais}

- Crise entre as organizações participantes do processo

- Centralização do poder na cúpula

- Diminuição da comunicação com os níveis hierárquicos médio e baixo

- Mentalidade de combate e guerra

- Tensão interpessoal e intergrupal

- Baixa geração de insights

Adaptado de Marks \& Mirvis (1998)

O trabalho dos Autores tem um enfoque predominante na questão das diferenças entre as empresas, gerando possíveis impactos negativos no momento de integração dos distintos modelos organizacionais. Vale a pena destacar que a questão da diversidade tem sido verificada também por outros autores como um grande desafio a ser gerenciado no momento da integração entre empresas participantes de acordos de combinação (Pritchet, 1997; Barros, 2003).

Pritchet (1997) destaca o possível choque entre as pessoas, resultante das diferenças entre as empresas, como principal fator que leva ao fracasso das combinações. Este choque, de acordo com as suas reflexões, ocorre quando há inconsistência entre "o velho estilo de fazer as coisas” e o novo modelo de atuação da empresa resultante do acordo negociado. Esta dissonância gera sentimentos de confusão e frustração nos profissionais, causando queda de 
produtividade das pessoas e levando, conseqüentemente, ao prejuízo do desempenho organizacional.

Estas tensões podem desdobrar-se também em elementos emocionais, conforme coloca Barros (2003). A Autora faz uma análise das reações dos indivíduos que participam destes processos comparando-as à vivência de perda de um ente querido, tomando como base os trabalhos do psicanalista John Bowlby e as quatro fases relacionadas às reações psicológicas de perda: raiva intensa e muitas vezes não compreensão do que está ocorrendo; saudade e busca do ente querido, apresentando tendências a identificar e reforçar as características positivas da organização ou do líder antigo; profundo momento de desespero e desorganização interna no qual a dor é aguda e parece eterna; e, por fim, reorganização e utilização da experiência vivida para visualizar desafios e oportunidades no novo momento da organização.

Uma analogia psicológica também é apresentada por Pritchet (1997), que identifica o aparecimento de instintos de auto-preservação das pessoas que participam de fusões e aquisições. Alguns dos profissionais defendem energicamente as suas posições, enquanto outros são mais cautelosos e eventualmente não fazem nada. O ponto mais relevante desta situação, salientado pelo Autor, corresponde à dispersão da energia existente na organização, perdendo-se o foco das questões relevantes para o futuro sucesso do negócio.

Os possíveis impactos das diferenças entre as organizações demonstram a necessidade de uma reflexão por parte da liderança das organizações em processos de aquisições e fusões, que deverá resultar na elaboração e implementação de abordagens de gestão da mudança compatíveis com os resultados esperados com a operação de combinação empresarial.

Os autores que mencionam as abordagens de gestão de mudança nas suas reflexões sobre as combinações empresariais identificam elementos que devem ser considerados na sua concepção. O primeiro deles relaciona-se ao estabelecimento de uma visão de futuro consistente com as diretrizes estratégicas do novo negócio e, ao mesmo tempo, atraente para os profissionais atuantes na organização.

Galpin \& Herndon (2000) apresentam que a criação de diretrizes e idéias orientadoras, cujo conteúdo faça sentido para os principais stakeholders da empresa, caracteriza-se como um 
fator crítico de sucesso das combinações entre empresas. Neste conteúdo estratégico formulado, os Autores reforçam a importância do foco no cliente, assim como a definição de padrões elevados para o atendimento das suas necessidades. Outros stakeholders também devem ser levados em consideração, visando o estabelecimento de relações positivas com os agentes sociais pertencentes ao ambiente no qual a organização está inserida.

A visão de futuro também aparece nos trabalhos do Marks \& Mirvis (1998) como um elemento importante no processo de liderança das operações de combinações empresariais. Por meio dela, os líderes mantém as pessoas focadas no que realmente é importante para o sucesso da nova organização. Além disso, o estabelecimento de princípios e prioridades para a integração define os níveis de autonomia das diversas áreas da organização, maximizando a eficácia do processo decisório. Fazem parte destes princípios as diretrizes estratégicas da nova configuração empresarial bem como modelos orientadores de comportamento, que vão desde conjunto de valores e regras de conduta até sistemas de gestão de competências demonstrando parâmetros para o desenvolvimento das pessoas.

Uma discussão emergente na elaboração da visão de futuro corresponde à decisão sobre a globalização ou localização do seu conteúdo na realidade das empresas subsidiárias, presentes nos países de atuação das corporações multinacionais. Esta análise torna-se bastante desafiadora, principalmente se forem levadas em consideração as diferentes realidades locais e a necessidade de adesão dos profissionais das subsidiárias às diretrizes empresariais elaboradas nas matrizes destas empresas.

Diante disso, a reflexão sobre a visão de futuro não pode ser deslocada da comunicação interna, criando canais com os executivos e empregados das organizações para viabilizar o comprometimento das pessoas com o novo modelo de negócios a ser implementado.

É interessante verificar que nos movimentos de aquisições e fusões, paralelamente ao stress e à insegurança, característicos da ambigüidade destas operações, Pritchet (1997) também destaca o enfraquecimento da confiança dos empregados em relação à organização em que trabalham. Uma vez que os profissionais apenas passam a ter conhecimento da operação no momento do comunicado oficial, evidencia-se um sentimento coletivo de traição por parte dos líderes da companhia. 
Além disso, muitos executivos, segundo Kay \& Shelton (2000), sentem-se extremamente desconfortáveis no momento de comunicação com os profissionais das suas equipes nos processos de aquisições e fusões em decorrência da dificuldade de responder as questões e dúvidas emergentes da insegurança característica destas transações.

Paralelamente, os rumores internos, de caráter negativo, são vistos por Galpin \& Herndon (2000) como um dos pontos relevantes que podem prejudicar a integração entre as empresas participantes de processos de aquisições e fusões. Diante disto, os Autores destacam a importância da comunicação interna, elaborada e implementada de maneira freqüente, aberta e honesta, com conteúdo relacionado aos esforços de integração e objetivos estratégicos definidos para a operação. Outro ponto salientado corresponde à pró-atividade do processo, evitando a necessidade de atuar de maneira defensiva frente a questionamentos posteriores.

Além da sugestão de utilizar vários canais, Galpin \& Herndon (2000) propõem quatro fases para a comunicação interna nas aquisições e fusões:

- Construção de consciência através da explicação clara do que está acontecendo na organização para toda a população;

- Identificação de potenciais problemas e reporte dos mesmos no status de acompanhamento do projeto;

- Ao longo da disseminação do processo de integração, comunicação de todas as mudanças ocorridas apropriadamente;

- Obtenção de feedbacks constantes, viabilizando a implementação dos ajustes necessários nos planos e projetos de integração entre as empresas.

Outro elemento fundamental no processo de mudança relacionado às aquisições e fusões corresponde à integração das políticas, processos e instrumentos de gestão das empresas participantes destas operações. Esta integração, importante para o funcionamento da empresa decorrente da combinação entre as suas antecessoras, é apontada por Lajoux (2006) como uma etapa complexa e delicada, com impactos diretos no sucesso da nova organização.

A dificuldade de tomada de decisão sobre a adoção de determinado sistema ou prática de gestão na nova organização demanda a criação de grupos de executivos compostos por 
profissionais oriundos de ambas as empresas participantes da operação. Galpin \& Herndon (2000) salientam a importância da criação destes grupos em diversas áreas funcionais, tais como marketing, comercial, finanças, recursos humanos e todas as demais funções relevantes para o funcionamento da operação, tendo como base sempre a clareza nos papéis, responsabilidades e expectativas em relação à sua atuação. Segundo os Autores, torna-se importante também criar uma instância decisória superior, responsável pela integração dos esforços destes diversos grupos para a tomada de decisão quanto à adoção de conceitos, práticas e instrumentos de gestão.

A discussão desta integração deve ser extrapolada também para a questão da gestão de recursos humanos. O modelo de gestão de recursos humanos, composto por políticas, práticas e instrumentos, utilizado ao longo do processo de combinação entre as empresas torna-se um elemento-chave para o sucesso da operação. Devem ser tomados cuidados específicos, no momento da transição, com o processo de seleção dos profissionais visando ocupar as posições da nova organização, assim como com os mecanismos estruturados para retenção de profissionais considerados importantes para a implementação da estratégia desenhada para a companhia.

A decisão de selecionar o melhor profissional para cada uma das posições da nova empresa torna-se relevante, seja em fusões entre empresas com características semelhantes ou mesmo em transações nas quais torna-se necessária a transformação significativa das organizações participantes da operação para a criação de um modelo organizacional distinto. Os autores que ressaltam a importância do processo seletivo nas combinações empresariais mencionam pontos relacionados à consistência dos critérios de seleção dos profissionais (Galpin \& Herndon, 2000) e a necessidade de clareza durante todo o processo, viabilizando uma percepção genérica de justiça e eqüidade (Marks \& Mirvis, 1998).

A discussão de processos seletivos aparece presente também nos trabalhos de Kay \& Shelton (2000), Light (2001) e Lajoux (2006) que propõem procedimentos concretos para a nomeação de profissionais para as posições na nova organização. Utilizando-se as propostas presentes nestas três referências bibliográficas, é possível detalhar quatro abordagens distintas e passíveis de implementação para a realização de uma seleção eficaz de gestores e profissionais em um processo de combinação entre empresas. 
A primeira delas corresponde à definição de um "novo líder” para determinada unidade de negócios. Caberá a este líder a identificação dos executivos mais adequados para a ocupação das posições correspondentes à estrutura desta unidade a partir do pool formado pelos profissionais das empresas anteriores. A vantagem desta abordagem é a agilidade do processo de tomada de decisão e, conseqüentemente, rápida ocupação de todas as posições minimizando o stress decorrente de indefinições. A desvantagem correspondente está ligada à potencial perda de profissionais da outra empresa, a qual não foi representada no processo de escolha dos ocupantes das novas posições. Significa dizer que, pelo fato de apenas um líder tomar as decisões relacionadas à nomeação das posições, apenas um grupo de profissionais terá sido bem representado no processo. Torna-se importante, portanto, estabelecer mecanismos que facilitem a obtenção de informações sobre os integrantes de todas as empresas envolvidas na combinação, independente da origem do líder estar em uma delas.

Uma alternativa a esta abordagem corresponde ao procedimento denominado two-in-a-box, no qual as duas companhias participantes da operação definem um líder para cada uma das unidades organizacionais e os dois devem trabalhar juntos no processo de nomeação de todas posições da estrutura organizacional concebida. A vantagem e a desvantagem desta abordagem têm natureza oposta ao modelo denominado novo líder, ou seja, os dois responsáveis pela tomada de decisão conhecem as características de todos os profissionais que compõem o pool caracterizando-se, portanto, como uma vantagem significativa. Porém, as dissonâncias de percepção e opinião entre estes dois líderes, oriundos de empresas e padrões culturais distintos, podem tornar o processo decisório moroso, aumentando as tensões características deste momento da combinação.

A terceira abordagem possível corresponde à utilização de uma empresa de consultoria especializada em recrutamento e seleção de executivos, a qual fica responsável pela identificação dos melhores profissionais para cada uma das posições. Estas empresas possuem, no seu repertório de atuação, técnicas e procedimentos especializados para o mapeamento de competências e características das pessoas compatíveis com as exigências das funções estabelecidas. A vantagem da minimização do viés dos executivos na definição dos melhores profissionais para as posições ofusca-se pela desvantagem correspondente ao 
elevado consumo de tempo necessário para a sua efetivação, o que pode tornar este procedimento inviável para fusões globais de grande porte.

Por fim, outra abordagem possível consiste na divulgação interna dos cargos, estimulando os profissionais a se candidatarem para cada uma das funções. Apesar da desvantagem também relacionada à baixa agilidade deste processo, decorrente da sua complexidade, a utilização deste mecanismo de recrutamento interno pode oferecer oportunidades de desenvolvimento pessoal e organizacional extremamente ricos para a transformação da organização.

Além da seleção dos profissionais corretos para compor a estrutura organizacional, a retenção de pessoas-chave, consideradas fundamentais para a implementação da estratégia futura, apresenta-se como um grande desafio para as organizações em processos de aquisições e fusões. De acordo com Kay \& Shelton (2000), as pessoas encontram-se vulneráveis às pressões exercidas por headhunters nos 5 dias posteriores à comunicação da efetivação das operações de combinação entre as empresas, tornando-se mais abertas e acessíveis às oportunidades de trabalho em outras organizações.

Galpin \& Herndon (2000) salientam a necessidade dos profissionais sentirem-se seguros neste momento e, além disso, desejarem fazer parte da nova organização. Para isso, os Autores propõem desde a inserção dos profissionais no processo decisório da construção da nova empresa até o pagamento de bônus para profissionais considerados essenciais para a mesma. É importante, entretanto, ressaltar a necessidade de cuidados com as questões de remuneração adicional, para que o custo correspondente a estas ações não prejudique os resultados financeiros iniciais da organização resultante da combinação.

Paralelamente aos esforços de seleção e retenção dos profissionais, outros pontos de gestão de recursos humanos devem ser gerenciados com cuidado como, por exemplo, a implementação de uma política de desligamento justa e responsável. Apesar do custo alto decorrente deste tipo de iniciativa, o impacto positivo junto aos profissionais que permanecem na organização influencia o clima organizacional interno e, indiretamente, facilita a retenção dos executivos da empresa. 
A utilização das referências bibliográficas sobre o tema leva, portanto, à identificação de quatro possíveis categorias de análise: visão de futuro, comunicação interna, processo de integração e gestão de recursos humanos.

O aprofundamento do referencial conceitual sobre mudança organizacional e a sua aplicação na etapa de integração pós-combinação leva ao aprimoramento do modelo de gestão da mudança em combinações empresariais formulado anteriormente. A tabela a seguir apresenta o modelo formulado anteriormente com os aperfeiçoamentos propostos no detalhamento da sua última etapa.

Tabela 4: Modelo de gestão da mudança com aprimoramento da etapa de integração pós-combinação

\begin{tabular}{|c|c|}
\hline $\begin{array}{l}\text { Etapas da } \\
\text { combinação }\end{array}$ & Detalhamento das etapas \\
\hline $\begin{array}{l}\text { Planejamento } \\
\text { estratégico }\end{array}$ & \\
\hline $\begin{array}{l}\text { Prospecção de } \\
\text { oportunidades }\end{array}$ & \\
\hline $\begin{array}{l}\text { Avaliação de } \\
\text { oportunidades }\end{array}$ & \\
\hline $\begin{array}{l}\text { Negociação e } \\
\text { efetivação do } \\
\text { acordo }\end{array}$ & \\
\hline $\begin{array}{l}\text { Integração pós- } \\
\text { combinação }\end{array}$ & $\begin{array}{l}\text { - Estabelecimento de visão de futuro para a empresa, composta por } \\
\text { diretrizes e estratégias capazes de orientar a atuação dos profissionais } \\
\text { no novo modelo organizacional; } \\
\text { - Estruturação de processo de comunicação interna, viabilizando o } \\
\text { estabelecimento de relações positivas entre a liderança da empresa e } \\
\text { os profissionais participantes do processo de integração; } \\
\text { - Elaboração de mecanismo consistente para a integração das } \\
\text { políticas, processos e instrumentos de gestão da nova organização, } \\
\text { viabilizando a implementação do modelo de negócios concebido; } \\
\text { - Concepção e implementação de políticas e práticas de gestão de } \\
\text { recursos humanos, alinhadas às diretrizes estratégicas definidas para } \\
\text { a nova organização. }\end{array}$ \\
\hline
\end{tabular}




\section{PARTE III: PESQUISA EMPÍRICA}

\section{Introdução}

Esta parte da tese é composta pelos capítulos relacionados à pesquisa empírica, propostos de acordo com os objetivos definidos anteriormente para este trabalho.

O primeiro capítulo contém o detalhamento do referencial metodológico desenhado. São especificadas as técnicas de levantamento e análise de dados utilizadas para a compreensão da formação e desenvolvimento do conceito de ciências da vida e para o estudo de caso proposto

São apresentados na sequência os resultados do levantamento e análise dos dados coletados junto aos profissionais da empresa estudada. Para a contextualização do estudo de caso, são utilizadas informações sobre a evolução da indústria química e a emergência do setor industrial das ciências da vida. Esta evolução é ilustrada com o histórico de empresas tradicionais químicas que migraram a sua atuação ou desenvolveram atividades que vieram a constituir este novo setor de produção econômica. 


\section{CAPÍTULO 4: REFERENCIAL METODOLÓGICO}

\subsection{Definições gerais}

O presente trabalho tem como objetivo contribuir para o aprimoramento do referencial teórico e instrumental que dê apoio às combinações entre empresas, propondo um modelo para a gestão das mudanças advindas deste tipo de transação. O estudo foca o processo de combinações de empresas de um setor específico - a indústria das ciências da vida - que emergiu a partir de transformações ocorridas no setor químico.

De acordo com o referencial teórico construído, a dinâmica estratégica do setor a ser pesquisado tem influência no formato dos modelos de gestão de mudança a serem concebidos e implementados para a efetivação das operações. Dessa forma, ao propor um estudo neste setor específico, torna-se importante refletir sobre as razões estratégicas que levaram as empresas a realizarem aquisições e fusões, resultando na formação e no desenvolvimento deste novo conceito na indústria química.

A natureza do problema de pesquisa, por sua vez, sugere a postura epistemológica pragmática, de acordo com proposta de Cresswell (2003), com o objetivo de aprimorar o arcabouço conceitual disponível em ciências sociais a partir de ações, situações e problemas de pesquisa. Neste tipo de estudo, o Autor identifica a possibilidade de utilização de abordagens multi-métodos, combinando técnicas qualitativas e quantitativas, que propiciem o refinamento do problema de investigação.

A abordagem metodológica escolhida para o estudo foi também influenciada pela constatação de que as combinações entre empresas constituem-se em fenômenos de mudança de larga escala, isto é, configuram-se em processos amplos e profundos que transformam o caráter da organização. Sua compreensão, segundo Pettigrew \& Wipp (1991), deve considerar o conhecimento da história da organização, assim como a análise ampla do momento em que se efetivam as mudanças, englobando características próprias da empresa e do setor econômico em que a mesma se insere. Os elementos macroeconômicos, políticos e sociais são, portanto, 
contrapostos à especificidade organizacional para compor o cenário compreensivo do processo de transformação estudado.

Torna-se relevante, para isso, a proposição de dois eixos de análise deste fenômeno: um de caráter horizontal e outro vertical. O eixo horizontal apóia-se nos antecedentes históricos, construindo uma linha seqüencial do tempo através da qual se pretende identificar o porquê da mudança. O outro, de caráter vertical, fundamenta-se em uma análise multidimensional do momento em que a combinação entre as empresas se concretiza, fornecendo insumos para compreender a ocorrência do fenômeno de mudança específico. Compõem-se, assim, um modelo de gestão da mudança definido pelo o quê está sendo alterado, ou seja, quais são os focos concretos das ações modificadoras e o como estas ações estão sendo implementadas, correspondente aos métodos adotados para a realização da transformação organizacional.

A proposição destes eixos baseia-se nas críticas de Pettigrew (1985) aos estudos sobre mudança organizacional, avaliados pelo Autor como carentes de análise histórica e de caracterização do contexto no qual se inserem as organizações. Nestes estudos, segundo o Autor, o programa de mudança apresenta-se como uma unidade de análise dissociada do contexto imediato, ou mesmo distante historicamente das condições que o fizeram emergir. A análise do continuum histórico, na opinião de Pettigrew (1985), torna-se indispensável uma vez que viabiliza a compreensão de possibilidades e limitações para a efetiva gestão do processo de mudança ao esclarecer as causas e os antecedentes determinantes. Schein (1986) também apresenta a importância da análise histórica das organizações e propõe a identificação de incidentes críticos para a decodificação de pressupostos básicos da sua cultura, que podem ser esclarecedores das possibilidades e limitações da transformação das empresas.

Esta crítica aos estudos de mudança e processos de desenvolvimento organizacional levou à proposição da abordagem contextualista da mudança, composta por três dimensões de análise que, segundo Pettigrew \& Wipp (1991), apresentam-se integradas e não podem ser dissociadas: contexto, conteúdo e processo. O contexto da mudança divide-se entre externo e interno, abrangendo elementos políticos, econômicos e sociais do ambiente, concomitantemente aos componentes do contexto interno como padrões culturais, competências instaladas e recursos disponíveis. O conteúdo refere-se aos principais focos da 
mudança, contendo informações concretas sobre produtos e mercados da organização, assim como sobre metas e indicadores de desempenho passíveis de avaliação. Por fim, o processo caracteriza os modelos e metodologias a serem utilizados para implementar as mudanças, bem como o papel dos gestores, dos líderes e dos grupos envolvidos nesse processo.

Fischer (1993; 1994; 2002) critica as proposições da mudança como um episódio tópico e pontual. A Autora propõe um processo sustentado e integrado de mudança organizacional que considera como pressuposto a necessidade de contínua adequação da empresa aos estímulos de aperfeiçoamento e de desenvolvimento provenientes do seu contexto interno e externo. A mudança deixa de ser vista como ocorrência episódica e passa a ser considerada como um fenômeno complexo e abrangente, cujo entendimento depende da interação sistêmica entre o porquê, o quê e como mudar refletindo, respectivamente, as dimensões de contexto, conteúdo e processo, conforme demonstra a figura a seguir.

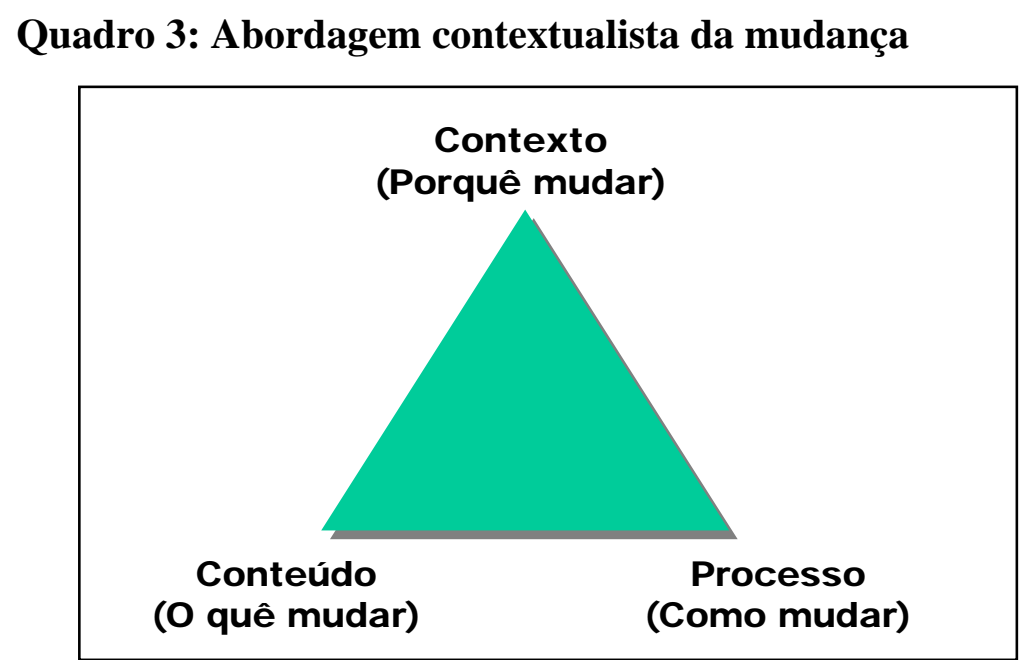

Fonte: Fischer (1993)

A complexidade da combinação entre empresas, analisada como um fenômeno de mudança de larga escala, demanda a construção de um desenho metodológico robusto e consistente, composto por técnicas de levantamento e análise de dados, estruturadas e encadeadas de acordo com as necessidades dos eixos vertical e horizontal propostos. Com ele procura-se abranger a compreensão da natureza estratégica das combinações empresariais e dos processos de gestão de mudança, concebidos e implementados para efetivar o novo empreendimento delas resultante. 
Além disso, a aplicação das três dimensões - contexto, conteúdo e processo - leva à necessidade de escolha de um setor da economia para que sejam realizados estudos de caso nas empresas que passaram por operações de aquisições e fusões. Trabalha-se assim com bases de dados que propiciam o entendimento da evolução das empresas, assim como do desenvolvimento do próprio setor em que elas estão inseridas.

Visando criar as condições para uma análise estruturada e detalhada do fenômeno das combinações empresariais, conforme definido na delimitação do problema de investigação proposto, o setor escolhido para o estudo foi o de ciências da vida, compreendendo a sua formação e desenvolvimento, a partir da indústria química tradicional.

A escolha deste setor como campo empírico da pesquisa não teve como objetivo esgotar o conceito de organizações especializadas em ciências da vida, mas sim analisar a importância da transição das empresas químicas tradicionais para a formação de um novo setor de negócios. Os processos de mudança em larga escala vivenciados por estas empresas ocorreram no bojo de uma série de movimentos de fusões, aquisições e cisões, o que possibilitou observar a relevância de estudar essas combinações empresariais e as suas implicações para a gestão das transformações organizacionais.

A pesquisa foi modelada em duas etapas. Na primeira delas, foram levantados e analisados dados para descrever a emergência e o desenvolvimento do conceito de ciências da vida, assim como a sua aplicação às operações de combinação empresarial no setor químico multinacional. A segunda etapa focou-se no propósito de elaborar um modelo de gestão da mudança para este tipo de transação. Foi realizado o estudo de caso de uma combinação entre empresas de grande porte com o objetivo de fortalecer a sua atuação no setor de ciências da vida. Neste estudo, buscou-se compreender as diretrizes estratégicas do negócio que levaram à adoção da combinação; as etapas implementadas para a efetivar a transação; e, as possíveis abordagens para gerir a mudança dela decorrentes. 
Para garantir a consistência da proposta metodológica adotada, foram explicitadas as questões de pesquisa estruturadas e as técnicas de levantamento e análise de dados empregadas. A tabela 5 procura sistematizar estes elementos componentes do desenho metodológico da pesquisa, nos moldes recomendados por Mazzon (1981), que denominou esta estrutura de “matriz de amarração” da metodologia de investigação empírica. 
Tabela 5: “Matriz de Amarração” para a pesquisa empírica

\begin{tabular}{|c|c|c|c|}
\hline Etapa & Objetivo da pesquisa & Questões da pesquisa & Técnicas de levant. e análise de dados \\
\hline $\begin{array}{l}\text { Descrição da } \\
\text { formação e } \\
\text { desenvolvimento } \\
\text { do conceito de } \\
\text { ciências da vida. }\end{array}$ & $\begin{array}{l}\text { Construir uma base de dados do setor } \\
\text { químico global, com elementos do } \\
\text { contexto ambiental e características } \\
\text { gerais das organizações que o } \\
\text { compõem. } \\
\text { Identificar as principais operações de } \\
\text { combinação entre empresas do setor } \\
\text { químico, que visam implementar o } \\
\text { conceito de ciências da vida como } \\
\text { diretriz estratégica de negócios. }\end{array}$ & $\begin{array}{l}\text { Condicionantes históricos que levaram ao } \\
\text { desenvolvimento e à configuração atual da } \\
\text { indústria química, bem como os seus } \\
\text { desdobramentos para a formação e } \\
\text { desenvolvimento do setor de ciências da } \\
\text { vida. } \\
\text { Operações de aquisições, fusões e cisões } \\
\text { entre as empresas químicas ao longo da sua } \\
\text { história, resultando na constituição do setor } \\
\text { de ciências da vida. }\end{array}$ & $\begin{array}{l}\text { Pesquisa bibliográfica junto a associações } \\
\text { relacionadas aos setores químico e de } \\
\text { ciências da vida. } \\
\text { Análise documental do histórico das } \\
\text { principais empresas que compõem este } \\
\text { setor, construindo uma "linha do tempo" } \\
\text { para cada uma delas, desde a sua formação } \\
\text { até o momento da realização da pesquisa. }\end{array}$ \\
\hline $\begin{array}{l}\text { Proposição de } \\
\text { um modelo de } \\
\text { gestão da } \\
\text { mudança para } \\
\text { casos de } \\
\text { combinação } \\
\text { empresarial. }\end{array}$ & $\begin{array}{l}\text { Estudar em profundidade o caso de um } \\
\text { processo de mudança de larga escala } \\
\text { relacionado à combinação entre } \\
\text { empresas que adotaram o conceito de } \\
\text { ciências da vida como diretriz } \\
\text { estratégica de negócios. } \\
\text { Aprimorar o modelo de gestão de } \\
\text { mudança, tornando-o operacional para } \\
\text { aplicação nas situações específicas de } \\
\text { combinações empresariais do setor de } \\
\text { ciências da vida. }\end{array}$ & $\begin{array}{l}\text { Diretrizes estratégicas que levaram à decisão } \\
\text { de efetivação da combinação empresarial. } \\
\text { Etapas implementadas ao longo de todo o } \\
\text { processo, identificando-se os pontos } \\
\text { positivos e as dificuldades encontradas, } \\
\text { seguindo o modelo de gestão da mudança } \\
\text { proposto no referencial teórico deste } \\
\text { trabalho. } \\
\text { Formulação de questões diretrizes sobre o } \\
\text { nível de desenvolvimento das abordagens de } \\
\text { gestão de mudança implementadas no caso } \\
\text { estudado, utilizando-se como base as } \\
\text { categorias propostas na etapa de integração } \\
\text { pós-combinação do modelo de gestão da } \\
\text { mudança formulado. }\end{array}$ & $\begin{array}{l}\text { Entrevistas semi-estruturadas com } \\
\text { profissionais da cúpula da empresa } \\
\text { selecionada, envolvidos diretamente na } \\
\text { transação que foi objeto do estudo de caso. } \\
\text { Aplicação de questionário com o grupo de } \\
\text { profissionais envolvidos diretamente no } \\
\text { processo de combinação empresarial. } \\
\text { Interpretação e análise qualitativa do } \\
\text { material coletado nas entrevistas. } \\
\text { Análise quantitativa dos dados obtidos nas } \\
\text { respostas do questionário aplicado, } \\
\text { utilizando-se tratamento estatístico Alfa de } \\
\text { Crombach, análise fatorial e testes de } \\
\text { hipóteses. }\end{array}$ \\
\hline
\end{tabular}




\subsection{Detalhamento técnico do levantamento e análise de dados}

\subsubsection{Etapa 1: Formação e desenvolvimento do conceito de ciências da vida}

Esta etapa da pesquisa teve como objetivo construir uma base de dados para viabilizar ampla compreensão do setor escolhido, desde a sua formação até a atualidade. Diante do conhecimento disponível e dos resultados do levantamento de informações, buscou-se também esboçar perspectivas e tendências para o seu futuro. Este levantamento propicia a reflexão sobre as pressões externas que levaram organizações a decidirem pela implementação de combinações empresariais como uma opção estratégica para ampliar a sua atuação no setor de ciências da vida que vinha se formando.

Para isso, foram utilizadas a pesquisa bibliográfica e documental sobre a indústria química, coletando publicações relevantes em entidades representativas deste setor tais como associações, sindicatos, centros de pesquisa e empresas de consultoria.

A partir deste levantamento inicial, foram identificados os principais casos de aquisições, fusões e cisões que resultaram na configuração atual das empresas químicas que passaram a atuar em ciências da vida. Tornou-se necessário, portanto, um estudo detalhado da história destas organizações, identificando-se os incidentes críticos (Schein, 1986), isto é, os episódios e situações que exigiram decisões no sentido de transformar a trajetória de direcionamento estratégico das empresas e realizar estas combinações.

Estes incidentes críticos foram mapeados compondo-se linhas do tempo com os eventos relevantes, que expressassem a evolução destas organizações desde a sua formação até a atualidade. Foram levantadas informações de cada uma delas sobre o seu surgimento; composição do seu portfolio de produtos; movimentos de expansão e retração da sua atuação; e, decisões referentes à implementação de estratégias de concentração ou especialização no setor químico. Cada uma destas empresas, bem como os processos de combinação empresarial pelos quais passaram, foram considerados passíveis de serem selecionadas para o estudo de caso da segunda etapa da pesquisa, na qual seria focado o modelo de gestão das mudanças provocadas por estas combinações empresariais. 


\subsubsection{Etapa 2: Estudo de caso}

A proposição do modelo de gestão da mudança para as combinações entre organizações ocorre em dois estágios de amadurecimento. O primeiro deles, essencialmente teórico, baseiase nos conceitos extraídos da literatura que serve de referencial para este trabalho. Ela propiciou elaborar um modelo genérico de etapas características deste tipo de transação empresarial.

O segundo estágio corresponde à aplicação destes conceitos teóricos em uma realidade empírica, delimitada de acordo com as definições deste referencial metodológico. Esta aplicação leva à operacionalização do modelo genérico formulado em uma realidade prática. Foi escolhido, para isso, o caso de uma organização multinacional e utilizou-se como objeto de pesquisa duas aquisições efetivadas pela empresa nos Estados Unidos durante o ano de 2004.

Yin (1990) reforça a importância do estudo de caso como uma "forma de se fazer pesquisa social empírica ao investigar-se um fenômeno atual dentro de seu contexto de vida real”, viabilizando a compreensão ampla do fenômeno. Goode \& Hatt (1973) reforçam a importância desta escolha metodológica, uma vez que o estudo de caso possibilita a preservação do caráter unitário do objeto social estudado, fornecendo elementos para a compreensão das suas especificidades.

O estudo de caso foi realizado utilizando-se um conjunto de técnicas de levantamento e análise de dados, encadeadas de maneira coerente com os objetivos do trabalho e alinhadas à intenção de promover uma compreensão do fenômeno da combinação, assim como da empresa e do ambiente no qual ela está inserida. Partiu-se do pressuposto de que a análise da combinação empresarial deve estar contextualizada pelo entendimento detalhado das características da organização e da sua inserção no ambiente, compondo o eixo horizontal de análise na proposta metodológica de Pettigrew \& Wipp (1991).

Para tanto, optou-se pela utilização de análise documental, entrevistas semi-estruturadas e questionários, aproveitando a potencialidade de cada uma destas técnicas para obter os dados e informações desejados. 
A análise documental viabilizou a compreensão do histórico da organização desde a sua formação e do seu relacionamento com as entidades do ambiente, compondo as variáveis temporais características do eixo horizontal da análise contextualista. Os documentos levantados também puderam ampliar a construção do eixo vertical de análise do fenômeno pesquisado. Neste caso, foram solicitados documentos relevantes, os quais foram concebidos e utilizados pela empresa durante a condução do processo de combinação tais como o anúncio da efetivação da operação e as comunicações realizadas durante o período de transição.

Os dados levantados através das entrevistas semi-estruturadas e da aplicação dos questionários permitiram construir o eixo vertical, que leva à compreensão em profundidade das aquisições implementadas, mediante à coleta das opiniões dos diversos atores envolvidos.

O detalhamento técnico das entrevistas realizadas e dos questionários aplicados são apresentados a seguir.

\subsubsection{Características das entrevistas semi-estruturadas}

A seleção dos profissionais para as entrevistas foi realizada utilizando-se os seguintes critérios:

- Envolvimento direto do executivo na transação realizada, possibilitando expressar a sua opinião e aprendizado relacionado às aquisições;

- Identificação de entrevistados que atuam em diferentes áreas de expertise, aumentando a riqueza e diversidade das opiniões coletadas diante de diferentes perspectivas de análise;

- Executivos atuantes na matriz da empresa e no local onde ocorreu o processo de combinação organizacional, possibilitando a comparação de suas diferentes perspectivas e opiniões sobre o mesmo fenômeno;

- Percepções de consultores externos que participaram da transação, ampliando a possibilidade de análise do processo pela inserção de visões dos diversos atores envolvidos. 
Com base nestes critérios, foram selecionados os seguintes profissionais para a realização das entrevistas semi-estruturadas.

Tabela 6: Composição do grupo de profissionais entrevistados

\begin{tabular}{|c|c|c|}
\hline $\begin{array}{l}\text { Executivos localizados na matriz da } \\
\text { empresa }\end{array}$ & $\begin{array}{l}\text { Executivos responsáveis pelo } \\
\text { negócio nos Estados Unidos }\end{array}$ & Conselheiros externos \\
\hline 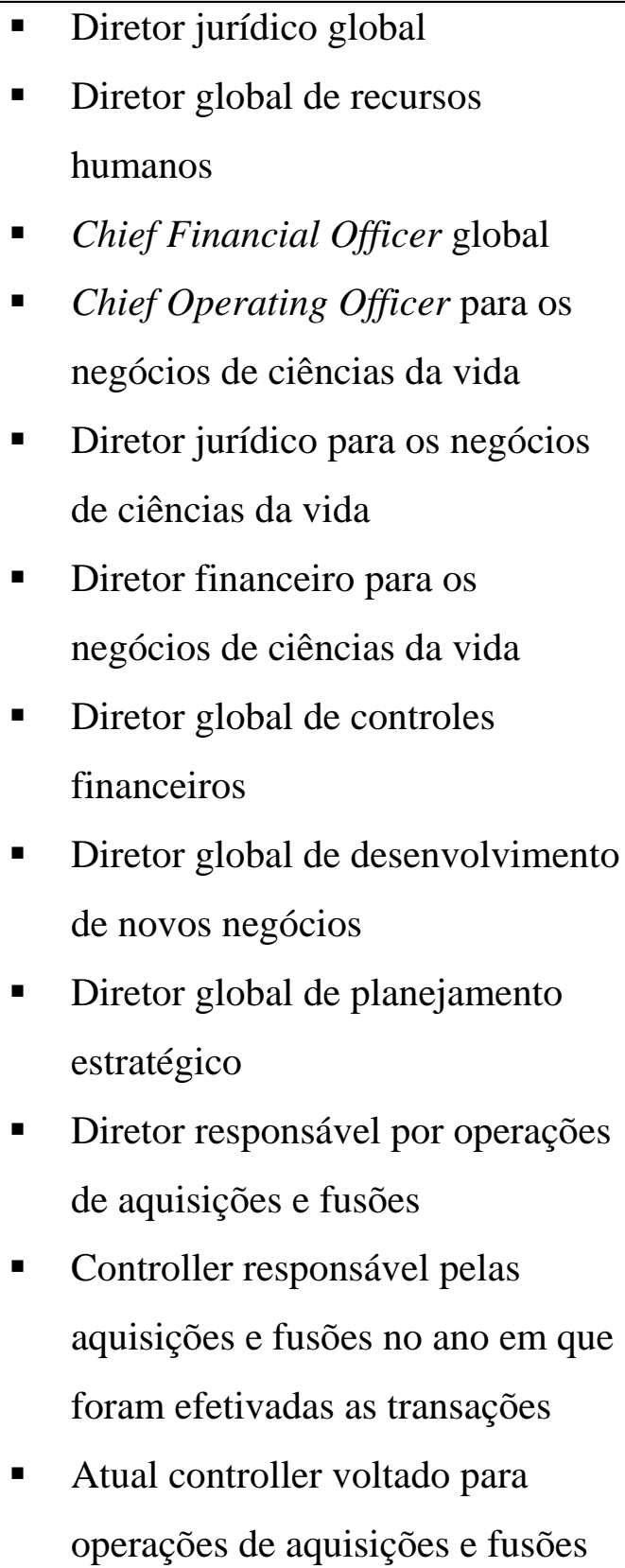 & 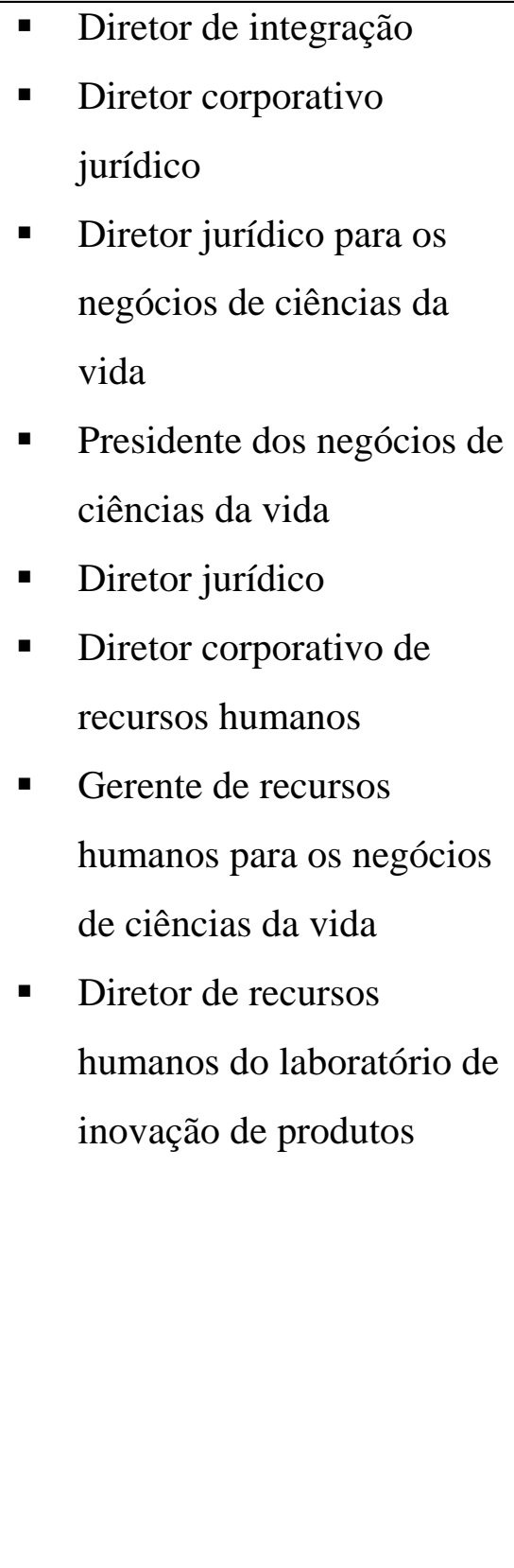 & 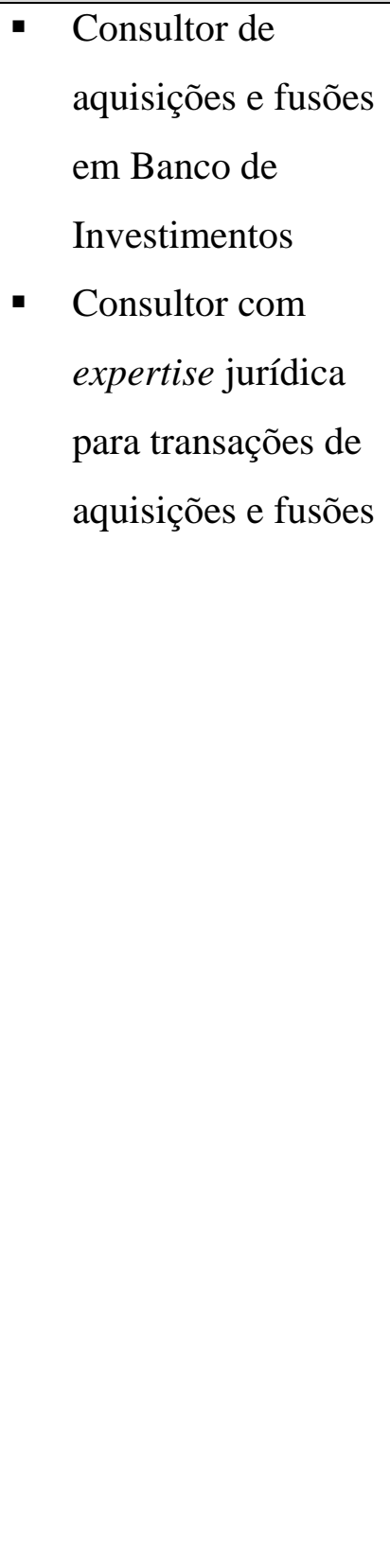 \\
\hline
\end{tabular}




\section{Roteiro de entrevistas}

O roteiro para a condução das entrevistas foi estruturado em três partes. A primeira delas teve como objetivo apresentar o escopo do levantamento de dados e identificar o histórico do profissional na empresa, assim como o papel desempenhado por ele nas aquisições analisadas.

O detalhamento de cada uma das etapas da aquisição, seguindo o modelo genérico proposto no referencial teórico deste trabalho, foi previsto para a segunda parte da entrevista. Neste momento, os executivos refletiram sobre os elementos positivos e negativos de cada uma das etapas propostas, especificando o que consideram que funcionou bem no processo e o que deveria ser aperfeiçoado. A terceira parte foi desenhada com o objetivo de estimular uma reflexão sobre o processo da aquisição como um todo e o aprendizado que poderia servir de insumo a operações de mesma natureza pela empresa.

As perguntas que compuseram o roteiro apresentam-se abaixo, traduzidas para o português. A versão original do roteiro em inglês, conforme foi aplicado junto aos entrevistados, encontrase no Apêndice B deste trabalho.

\section{Parte 1: Introdução, histórico do profissional e participação na transação}

- Qual é o seu cargo atual? Faça uma retrospectiva do seu histórico na organização.

- Qual foi o trabalho no qual você esteve envolvido ou foi responsável nas aquisições realizadas nos Estados Unidos?

- Você tinha uma visão clara de quais seriam os padrões de resultado a serem alcançados pela operação?

- Como a informação foi gerenciada junto aos grupos e profissionais envolvidos ao longo do processo?

- O que você aprendeu com esta experiência? O que você faria diferente se fosse realizar participar novamente desta combinação? O que você repetiria? Que aprendizado há neste processo e que poderia ser compartilhado com profissionais envolvidos em novas aquisições? 
Parte 2: Reflexões sobre as etapas da combinação, utilizando-se o modelo genérico de gestão da mudança proposto no referencial teórico dste trabalho

\begin{tabular}{|c|c|c|}
\hline Detalhamento das etapas & $\begin{array}{l}\text { O que deu } \\
\text { certo? }\end{array}$ & $\begin{array}{c}\text { O que poderia } \\
\text { ser } \\
\text { melhorado? }\end{array}$ \\
\hline $\begin{array}{l}\text { Planejamento estratégico } \\
\text { - } \quad \text { Elaboração de cenários futuros para a organização e possíveis } \\
\text { diretrizes estratégicas a serem implementadas } \\
\text { - } \quad \text { Identificação de gaps no modelo de negócios da empresa } \\
\text { para a efetivação das diretrizes estratégicas estabelecidas }\end{array}$ & & \\
\hline $\begin{array}{l}\text { Prospecção de oportunidades } \\
\text { - } \quad \text { Identificação de oportunidades no mercado para suprimir os } \\
\text { gaps identificados na etapa de planejamento estratégico } \\
\text { - } \quad \text { Estabelecimento de objetivos para potenciais combinações e } \\
\text { identificação de benefícios com o processo }\end{array}$ & & \\
\hline $\begin{array}{l}\text { Avaliação de oportunidades } \\
\text { - } \quad \text { Atuação de diferentes áreas de expertise-financeira, jurídica, } \\
\text { RH e comercial - para levantamento de informações nas } \\
\text { empresas target } \\
\text { - } \quad \text { Identificação de riscos e análise da compatibilidade com o } \\
\text { critério estratégico definido inicialmente pela organização } \\
\text { para a efetivação da combinação } \\
\text { - Confirmação da decisão para a continuidade do processo }\end{array}$ & & \\
\hline $\begin{array}{l}\text { Negociação e efetivação do acordo } \\
\text { - } \quad \text { Definição de possível intervalo de preços e condições para a } \\
\text { efetivação da transação } \\
\text { - } \quad \text { Negociação com as empresas target ou seus representantes } \\
\text { - } \quad \text { Articulação interna com as devidas instâncias da organização } \\
\quad \text { para a aprovação do acordo referente à transação }\end{array}$ & & \\
\hline $\begin{array}{l}\text { Integração pós-combinação } \\
\text { - Estabelecimento de uma clara visão de futuro para a } \\
\text { empresa, composta por diretrizes e estratégias capazes de } \\
\text { orientar a atuação dos profissionais no novo modelo } \\
\text { organizacional; } \\
\text { - Estruturação de processo de comunicação interna, } \\
\text { viabilizando o estabelecimento de relações positivas entre a } \\
\text { liderança da empresa e os profissionais participantes do } \\
\text { processo de integração; } \\
\text { - Elaboração de mecanismo consistente para a integração das } \\
\text { políticas, processos e instrumentos de gestão da nova } \\
\text { organização, viabilizando a implementação do modelo de } \\
\text { negócios concebido; } \\
\text { Concepção e implementação de políticas e práticas de gestão } \\
\text { de recursos humanos, alinhadas às diretrizes estratégicas } \\
\text { definidas para a nova organização. }\end{array}$ & & \\
\hline
\end{tabular}




\section{Parte 3: Processo em geral}

- O processo ocorreu de acordo com as suas expectativas iniciais?

- O time dedicado à aquisição cumpriu a sua missão?

- O que facilitou e o que dificultou o trabalho da equipe dedicada à combinação?

- Que elementos deveriam ser trabalhados na etapa de integração para garantir a efetividade das aquisições realizadas no futuro?

- Que conselhos você daria para outras equipes empenhadas neste tipo de projeto?

- Há algum outro elemento que você gostaria de adicionar?

\subsubsection{Características do questionário}

Este instrumento de levantamento de dados visava coletar as opiniões dos respondentes sobre as categorias que compõem a etapa de integração pós-combinação, com o objetivo de gerar insumos para o aprimoramento do modelo de gestão da mudança em combinações empresariais. Ele foi aplicado junto aos profissionais da empresa sediados nos Estados Unidos e que estiveram diretamente envolvidos na transação analisada.

O questionário elaborado, com a versão original em inglês aplicada nos Estados Unidos e tradução para o português, encontra-se no Apêndice C deste trabalho. Alguns pontos em relação a este instrumento devem ser salientados.

As questões iniciais do instrumento foram elaboradas com o objetivo de identificar a função atual dos profissionais e também a empresa a que pertenciam antes das aquisições analisadas neste trabalho. Dessa forma, foi possível separar a opinião dos executivos da empresa adquirente daquelas dos funcionários das empresas adquiridas.

As questões subseqüentes, que enfocam as categorias da etapa de integração pós-combinação, foram elaboradas utilizando-se como base os conceitos teóricos adotados neste trabalho e que se relacionavam, especificamente, com a gestão da mudança em operações de combinação empresarial. Foram consideradas, portanto, as quatro categorias que a literatura indica como 
componentes da etapa de integração pós-combinação: visão de futuro, comunicação interna, processo de integração e gestão de recursos humanos.

As informações coletadas nas entrevistas também trouxeram contribuições valiosas para a elaboração destas questões. Em primeiro lugar, forneceram elementos para o detalhamento de variáveis para cada uma das categorias elaboradas no referencial teórico, permitindo que o questionário fosse mais completo e adequado à realidade dos respondentes. Além disso, foi possível inserir nas questões conteúdos específicos da empresa tais como as características próprias de sua estratégia, do seu modelo organizacional e das políticas e processos adotados.

Foram inseridas também questões abertas no instrumento de levantamento de dados, visando obter dados qualitativos que ampliassem a compreensão das informações oriundas das respostas quantitativas para enriquecer a qualidade da análise com exemplos e depoimentos específicos dos respondentes.

Embora os dados coletados nas entrevistas possibilitassem uma customização do questionário à realidade da população escolhida, foi realizado um pré-teste previamente à sua aplicação junto aos profissionais da empresa nos Estados Unidos, visando identificar potenciais dificuldades de compreensão. Os resultados obtidos propiciaram incorporar melhorias ao instrumento, assegurando a qualidade dos dados coletados.

Apresentam-se a seguir as questões do instrumento correspondentes a cada uma das categorias analíticas propostas no referencial teórico. Elas estão codificadas para facilitar a compreensão dos procedimentos estatísticos que foram aplicados aos resultados obtidos com o questionário.

\begin{tabular}{|l|l|}
\hline \multicolumn{2}{|l|}{ Visão de futuro } \\
\hline 4 A & Conheço e compreendo a estratégia de aquisições da empresa. \\
\hline 4 B & $\begin{array}{l}\text { Conheço as razões que fazem as aquisições da empresa Alfa gerarem valor } \\
\text { para os acionistas. }\end{array}$ \\
\hline 4 C & $\begin{array}{l}\text { Considero boa a idéia de implementar uma estratégia de complementação de } \\
\text { portfolio. }\end{array}$ \\
\hline 4 D & $\begin{array}{l}\text { As decisões tomadas até o momento suportam a estratégia de } \\
\text { complementação de portfolio elaborada. }\end{array}$ \\
\hline
\end{tabular}




\begin{tabular}{|c|c|}
\hline $6 \mathrm{~A}$ & $\begin{array}{l}\text { Estou otimista em relação à habilidade da empresa para gerar novos produtos } \\
\text { com alta performance. }\end{array}$ \\
\hline $6 \mathrm{~B}$ & $\begin{array}{l}\text { Estou otimista em relação à habilidade da empresa para gerar produtos sob } \\
\text { demanda. }\end{array}$ \\
\hline $6 \mathrm{C}$ & $\begin{array}{l}\text { Estou otimista em relação à habilidade da empresa para introduzir a estratégia } \\
\text { de complementação de portfolio com a diferenciação requerida. }\end{array}$ \\
\hline $6 \mathrm{D}$ & $\begin{array}{l}\text { Estou otimista em relação à habilidade da empresa para produzir e entregar os } \\
\text { produtos no tempo adequado. }\end{array}$ \\
\hline $8 \mathrm{~A}$ & $\begin{array}{l}\text { Tenho confiança na capacidade de implementação da estratégia do time de } \\
\text { liderança da empresa. }\end{array}$ \\
\hline $8 \mathrm{~B}$ & $\begin{array}{l}\text { Tenho confiança na capacidade de implementação da estratégia do time de } \\
\text { liderança da minha função. }\end{array}$ \\
\hline $8 \mathrm{C}$ & $\begin{array}{l}\text { Tenho confiança na capacidade de implementação da estratégia de todo o meu } \\
\text { time funcional. }\end{array}$ \\
\hline $8 \mathrm{D}$ & Tenho confiança na minha capacidade de implementação da estratégia. \\
\hline $20 \mathrm{~A}$ & $\begin{array}{l}\text { Conheço as expectativas em relação à minha atuação para a implementação da } \\
\text { estratégia. }\end{array}$ \\
\hline $20 \mathrm{~B}$ & As expectativas em relação à minha atuação são consistentes. \\
\hline $22 \mathrm{~A}$ & Sabemos qual é a visão de futuro e quais são os caminhos para atingí-la. \\
\hline $22 \mathrm{~B}$ & Estamos encontrando novos e melhores caminhos para fazer as coisas. \\
\hline $22 \mathrm{C}$ & Estou confiante em relação à nossa competitividade na indústria. \\
\hline $22 \mathrm{D}$ & Acredito que pertenço a um time vencedor. \\
\hline $22 \mathrm{E}$ & Estamos nos tornando mais inovadores. \\
\hline $22 \mathrm{~F}$ & $\begin{array}{l}\text { Os processos e procedimentos estão evoluindo de acordo com as estratégias } \\
\text { estabelecidas. }\end{array}$ \\
\hline
\end{tabular}

\begin{tabular}{|l|l|}
\hline \multicolumn{2}{|l|}{ Comunicação } \\
\hline $10 \mathrm{H}$ & Soube da minha situação profissional na empresa o mais breve possível. \\
\hline $12 \mathrm{~A}$ & A comunicação tem sido bastante aberta. \\
\hline $12 \mathrm{~B}$ & A comunicação tem sido passada no momento correto. \\
\hline $12 \mathrm{C}$ & $\begin{array}{l}\text { A quantidade de comunicação recebida foi suficiente. } \\
\text { minhas necessidades. }\end{array}$ \\
\hline $12 \mathrm{D}$ & $\begin{array}{l}\text { Meu gestor manteve-me informado a respeito dos planos de integração que } \\
\text { me afetariam. }\end{array}$ \\
\hline $12 \mathrm{E}$ & \begin{tabular}{l} 
A comunicação e coordenação entre times de integração foi efetiva. \\
\hline $12 \mathrm{~F}$
\end{tabular} \\
\hline
\end{tabular}




\begin{tabular}{|l|l|}
\hline $18 \mathrm{~F}$ & Estou começando a me identificar com a minha função na nova organização. \\
\hline $18 \mathrm{G}$ & $\begin{array}{l}\text { Meus pares estão começando a se identificar com a suas funções na nova } \\
\text { organização. }\end{array}$ \\
\hline $20 \mathrm{C}$ & Eu compreendo as metas operacionais da minha função. \\
\hline $20 \mathrm{D}$ & Eu compreendo as metas financeiras da minha função. \\
\hline $20 \mathrm{E}$ & $\begin{array}{l}\text { Meu gestor tem sido claro quanto às mudanças decorrentes da integração e as } \\
\text { suas causas. }\end{array}$ \\
\hline
\end{tabular}

\begin{tabular}{|c|c|}
\hline \multicolumn{2}{|c|}{ Processo de integração } \\
\hline $10 \mathrm{~A}$ & O processo de integração do negócio tem sido justo e objetivo. \\
\hline $10 \mathrm{C}$ & $\begin{array}{l}\text { As decisões-chave relacionadas à integração foram tomadas no tempo } \\
\text { adequado. }\end{array}$ \\
\hline $10 \mathrm{E}$ & $\begin{array}{l}\text { As decisões-chave relacionadas à localização do site de desenvolvimento de } \\
\text { produtos foram tomadas no tempo adequado. }\end{array}$ \\
\hline $10 \mathrm{~F}$ & $\begin{array}{l}\text { As decisões-chave relacionadas à localização do site de manufatura da } \\
\text { empresa foram tomadas no tempo adequado. }\end{array}$ \\
\hline $10 \mathrm{G}$ & $\begin{array}{l}\text { As decisões-chave relacionadas à localização do escritório central da empresa } \\
\text { foram tomadas no tempo adequado. }\end{array}$ \\
\hline $16 \mathrm{~A}$ & $\begin{array}{l}\text { Eu soube quem pertence ao meu time de integração e o seu conjunto de } \\
\text { atribuições e responsabilidades. }\end{array}$ \\
\hline $16 \mathrm{~B}$ & O time de integração relacionado à minha função foi efetivo e comunicativo \\
\hline $16 \mathrm{C}$ & $\begin{array}{l}\text { O time de integração relacionado à minha função teve os recursos necessários } \\
\text { para implementar com o sucesso a integração. }\end{array}$ \\
\hline $16 \mathrm{D}$ & $\begin{array}{l}\text { Há consistente planejamento para as atividades de integração previstas para os } \\
\text { próximos meses. }\end{array}$ \\
\hline $16 \mathrm{~F}$ & $\begin{array}{l}\text { Conheço a nova estrutura organizacional, assim como as atribuições e } \\
\text { responsabilidades das pessoas que atuam na minha área. }\end{array}$ \\
\hline $16 \mathrm{G}$ & Conheço as metas de integração para a sinergia de custos. \\
\hline $16 \mathrm{H}$ & $\begin{array}{l}\text { Considero as metas de sinergia de custos consistentes e passíveis de serem } \\
\text { alcançadas. }\end{array}$ \\
\hline $16 \mathrm{I}$ & Meu gestor apóia o processo de integração. \\
\hline $18 \mathrm{~A}$ & Até o momento a integração tem sido um sucesso. \\
\hline $18 \mathrm{~B}$ & Os meus pares estão satisfeitos com a integração até o momento. \\
\hline $18 \mathrm{E}$ & $\begin{array}{l}\text { A carga de trabalho durante o processo de integração foi passível de } \\
\text { gerenciamento. }\end{array}$ \\
\hline $18 \mathrm{H}$ & $\begin{array}{l}\text { Os empregados têm neste momento energia suficiente para tornar a integração } \\
\text { um sucesso. }\end{array}$ \\
\hline
\end{tabular}




\begin{tabular}{|l|l|}
\hline \multicolumn{2}{|l|}{ Gestão de recursos humanos } \\
\hline $10 \mathrm{~B}$ & O processo de integração de recursos humanos tem sido justo e objetivo. \\
\hline $10 \mathrm{D}$ & $\begin{array}{l}\text { As principais decisões relacionadas à gestão de recursos humanos foram } \\
\text { tomadas no momento correto. }\end{array}$ \\
\hline $14 \mathrm{~A}$ & $\begin{array}{l}\text { As informações relacionadas às posições que ficariam disponíveis na minha } \\
\text { area foram bem organizadas e gerenciadas de maneira apropriada. }\end{array}$ \\
\hline $14 \mathrm{~B}$ & $\begin{array}{l}\text { O processo de aplicação para novas posições foi bem organizado e gerenciado } \\
\text { apropriadamente. }\end{array}$ \\
\hline $14 \mathrm{C}$ & $\begin{array}{l}\text { O processo de entrevistas para as novas posições foi bem organizado e } \\
\text { gerenciado de maneira apropriada. }\end{array}$ \\
\hline $14 \mathrm{D}$ & $\begin{array}{l}\text { Eu mudei de posição durante a integração e os termos aplicados foram } \\
\text { apropriados. }\end{array}$ \\
\hline $14 \mathrm{E}$ & $\begin{array}{l}\text { Eu fui realocado para um novo site da organização durante a integração e os } \\
\text { termos foram satisfatórios }\end{array}$ \\
\hline $14 \mathrm{~F}$ & $\begin{array}{l}\text { Tive respostas adequadas para as perguntas relacionadas à gestão de } \\
\text { remuneração. }\end{array}$ \\
\hline $14 \mathrm{G}$ & $\begin{array}{l}\text { A implementação da folha de pagamento e administração de benefícios foi } \\
\text { bem sucedida. }\end{array}$ \\
\hline $16 \mathrm{E}$ & $\begin{array}{l}\text { O tratamento dispensado aos profissionais que não receberam posições na } \\
\text { nova organização foi justo e respeitoso. }\end{array}$ \\
\hline $18 \mathrm{C}$ & $\begin{array}{l}\text { Ações relacionadas à retenção de profissionais-chave estão sendo } \\
\text { implementadas durante a integração. }\end{array}$ \\
\hline $18 \mathrm{D}$ & \begin{tabular}{l} 
A empresa continuará a reter profissionais-chave nos próximos seis meses. \\
\hline
\end{tabular} \\
\hline
\end{tabular}

\section{Análise estatística do questionário}

Foram utilizados os seguintes procedimentos estatísticos para tratamento dos dados obtidos com o questionário: análise fatorial, análise de consistência e teste de hipóteses. O detalhamento técnico de cada uma destas técnicas apresenta-se na sequência.

\section{Análise fatorial}

A utilização da análise fatorial possibilita dar um passo adicional no refinamento do modelo de gestão de mudança, inicialmente elaborado no referencial teórico deste trabalho. Com a aplicação deste procedimento estatístico, são analisados os coeficientes de correlação entre as 
diversas variáveis que compõem o questionário e, em decorrência disto, são propostos agrupamentos entre estas variáveis para a formação de fatores.

Os fatores são combinações lineares das 61 variáveis presentes nas questões, sendo que o coeficiente de cada uma delas é baseado na sua correlação com o seu respectivo fator. É importante destacar que quanto maior a correlação entre a variável e o fator, maior é o peso dela no cálculo do mesmo.

Torna-se possível, portanto, desafiar as categorias formuladas originalmente no referencial teórico para a sua validação como integrante do modelo de gestão da mudança ou propor diferentes combinações entre as variáveis e, conseqüentemente, esboçar novas categorias.

\section{Análise de consistência}

A análise de consistência, com base no coeficiente alfa de Crombach, visa identificar se o conjunto de variáveis escolhido para compor cada um dos agrupamentos identificados com a análise fatorial é adequado.

O alfa de Crombach, segundo Nunnally (1978), pode ser interpretado como uma medida de consistência entre a escala utilizada e todas as possíveis escalas que poderiam ser construídas com o mesmo número de variáveis. Significa dizer que este valor deve ser interpretado como uma medida de confiabilidade que varia no intervalo entre zero e um e, quanto maior este valor, maior a confiabilidade. Vale a pena salientar que, ao analisar as respostas do questionário, adotou-se a premissa de que os respondentes trataram as diferenças entre as distâncias das categorias de concordância como iguais.

Para a definição final das variáveis em cada uma das categorias, foram utilizados os critérios de correlação de cada uma delas com as demais, assim como o efeito da sua retirada na confiabilidade, medida pelo alfa de Crombach. A decisão de manutenção ou retirada de cada variável no conjunto das categorias foi tomada com base na maximização do valor de alfa. 


\section{Testes de hipóteses}

Foram elaborados dois testes de hipóteses. O primeiro deles com o objetivo de analisar o nível de desenvolvimento da abordagem de gestão da mudança implementada na etapa de integração pós-combinação do estudo de caso. O segundo teste foi desenhado para identificar a existência de diferença significativa de opinião entre os profissionais provenientes das empresas que participaram da transação.

A análise do nível de desenvolvimento foi realizada com base em medidas-resumo para cada uma das categorias propostas no modelo de gestão da mudança Estas medidas-resumo referem-se às médias das opiniões dos respondentes em relação às questões propostas e correspondem a valores contínuos de 1 a 4. Quanto maior o valor da medida-resumo, maior a concordância dos respondentes com as variáveis das categorias e, portanto, mais elevado o nível de desenvolvimento da abordagem de gestão de mudança implementada de acordo com a opinião dos profissionais da empresa.

$\mathrm{Na}$ análise seguinte, foi verificada a existência de diferença significativa entre as opiniões dos profissionais que vieram das três empresas que participaram da combinação. Foram comparadas as médias das opiniões destes profissionais para cada uma das categorias da etapa de integração pós-combinação do modelo de gestão da mudança.

A técnica estatística para comparar as 3 médias foi a Análise de Variância (ANOVA), seguida pelo método de comparações múltiplas de Tukey para localizar as diferenças. Para ilustrar os resultados, foram construídos gráficos com intervalos de confiança de 95\% para os escores médios e o nível de significância adotado foi 0,05.

\section{Considerações sobre o tratamento dos dados do questionário}

No processamento dos dados obtidos com o questionário, o valor cinco atribuído à resposta “não sei” não tem utilização prática uma vez que não faz sentido somar cinco pontos quando houver esta resposta. Estes itens foram então considerados como omissos ou, de acordo com a linguagem do sistema, denominados missing. Ao fazer a aplicação do procedimento 
estatístico, entretanto, o programa automaticamente exclui as observações com pelo menos um dado omisso. Isto traz grandes limitações para a análise uma vez que a amostra varia conforme os itens considerados pelo programa correspondendo, portanto, a apenas uma pequena parte da amostra total.

Com o intuito de analisar os possíveis vícios em decorrência da seleção de diferentes partes da amostra, foram utilizados dois tratamentos distintos dos dados obtidos: (1) utilizando os dados originais, com exclusão de dados omissos e respostas "não sei” e, portanto, considerando-se apenas uma seleção da amostra para a análise; e, (2) imputando os dados omissos e "não sei” como a mediana dos demais valores e, dessa forma, utilizando o total da amostra.

Foi escolhido o segundo enfoque para a realização da análise de consistência e fatorial. Esta estratégia teve como objetivo viabilizar a utilização do total da amostra para estas análises. Com os dados originais estas análises estatísticas utilizariam apenas uma pequena parte não representativa do total de questionários. 


\section{CAPÍTULO 5 - EVOLUÇÃO DA INDÚSTRIA QUÍMICA E A EMERGÊNCIA DAS CIÊNCIAS DA VIDA}

\subsection{Histórico}

A origem do setor de produção química remete à Revolução Industrial e está diretamente relacionada ao suprimento de matérias primas para a emergente indústria inglesa. É interessante observar que até o início do século XIX prevalece a liderança deste país como o maior produtor químico do mundo industrializado. Neste momento, segundo Sá (2002), a produção era constituída predominantemente de produtos inorgânicos, compostos de sais minerais. Em 1856, com a descoberta do corante sintético orgânico, fabricado a partir do carvão, tem início a diversificação de produtos gerados a partir de descobertas científicas.

Os alemães passam a desempenhar papel relevante neste processo, obtendo a liderança na indústria no final deste mesmo século, tendo como apoio um sistema de cooperação entre as empresas, as universidades e o governo. Neste país, no início do século XX, ocorreram as primeiras associações entre os fabricantes de corantes formando o maior grupo de empresas químicas - a IG Farben - a qual foi dissolvida em 1951 (Wongtschowski, 2002)

No período pós guerra, as empresas químicas que compunham a IG Farben foram repartidas entre as três maiores empresas químicas existentes antes de sua formação: Basf, Bayer, Hoechst. Com a ajuda econômica do Plano Marshall, com a reorganização da economia e com muita tenacidade e trabalho, a indústria química alemã começou a renascer das cinzas, auxiliada por dois eventos, de certa forma inesperados: a nova química derivada do petróleo a petroquímica - e a descoberta de importantes jazidas de petróleo no Oriente Médio.

Nos Estados Unidos, o final do século XIX é caracterizado pela criação de gigantes deste setor como, por exemplo, a Dupont (Marks \& Mirvis, 1998). Nas décadas de 20 e 30 do século seguinte, segundo os Autores, combinações ocorreram configurando integrações entre empresas e seus clientes ou seus fornecedores. Estes movimentos verticais deram origem a outras grandes empresas como a American Cyanamid. É importante mencionar o papel dos Estados Unidos nesta indústria, cuja influência aumentou significativamente com a Primeira 
Guerra Mundial, decorrente de conflitos e da interrupção do fornecimento de matérias primas alemãs.

Na Inglaterra também ocorreram fusões empresariais neste período. A criação da ICI (Imperial Chemical Industries) em 1926 teve forte estímulo do governo aumentando as vantagens competitivas da indústria local, frente às fortes pressões e domínio da indústria alemã.

Ainda no continente Europeu, especificamente na Suíça, foi também formado um pólo de desenvolvimento de empresas químicas, localizado próximo à fronteira com a Alemanha e França, na cidade de Basiléia. Neste local, empresas de destaque no setor, como a Ciba, Sandoz e Roche tiveram a sua origem e desenvolvimento a partir de universidades e centros de pesquisas.

O primeiro cartel internacional importante da indústria química, formado nesse período, foi o das empresas produtoras de corantes, realizado entre 1926 e 1929, com a participação da Alemanha, Suíça e França. A partir de 1932, a inglesa ICI também passa a compartilhar este conjunto empresarial. A repartição das vendas deste cartel tinha a seguinte distribuição: Alemanha com 65\%, Suíça com 17\% e França e Inglaterra com 9\% cada uma. O cartel detinha $80 \%$ da produção mundial de corantes e, em 1938, apesar da concorrência dos EUA, Japão Itália, suas vendas correspondiam a 62\% do comércio mundial deste produto.

No início da década de 90, fortes pressões relacionadas ao aumento da concorrência e conseqüente redução de rentabilidade levaram a indústria química a um novo posicionamento, ligado à busca de vantagens competitivas a partir da identificação de segmentos de mercado com elevadas margens de contribuição. As empresas passaram a transferir o seu modelo de negócios de produtos de baixa rentabilidade e produção em larga escala para outros tipos de negócios baseados em diferenciação pela qualidade e, portanto, padrões de lucratividade mais elevados. Foi um movimento de migração das commodities para especialidades químicas, através de processos de desverticalização e concentração de negócios (Héau, 2001). Surge então o conceito de ciências da vida para denominar parte específica deste setor produtivo, com substâncias químicas relacionadas a seres humanos, animais e plantas. 
Empresas representativas de diversos países iniciaram este tipo de transição migrando das commodities para as ciências da vida - Monsanto (Estados Unidos), Bayer, Basf e Hoechst (Alemanha), Rhone Poulenc (França), ICI (Inglaterra), Solvay (Bélgica) além de Ciba e Sandoz (Suíça) - configurando operações de aquisições, fusões e cisões. O histórico e a evolução destas empresas, com os principais momentos da sua trajetória desde a formação até o momento atual, apresentam-se nas linhas do tempo construídas, que encontram-se no Apêndice A deste trabalho. A compreensão deste reposicionamento das empresas demanda uma discussão específica sobre o a origem das ciências da vida no mundo empresarial.

\subsection{Ciências da vida: um setor industrial em construção}

O processo que leva à proposição do conceito de ciências da vida e ao desenvolvimento do setor de produção industrial a ele associado origina-se com o advento da biotecnologia (Fumento, 2003; Kotler \& Simon, 2004) e da economia molecular (Meyer \& Davis, 2003) na indústria química.

Kotler \& Simon (2004) elaboram ampla pesquisa sobre a biotecnologia, identificando revoluções que estão acontecendo em diversos setores, de medicamentos a armas e de alimentos a cosméticos. Ao estimar o impacto comercial significativo dos produtos biotecnológicos em economias de países desenvolvidos e subdesenvolvidos, os Autores denominam o século atual como a era da biotecnologia. No caso dos Estados Unidos, segundo Kotler \& Simon (2004), o porte das indústrias com atividades relacionadas à biotecnologia chega a abranger mais de US\$ 2 trilhões distribuídos entre produtos químicos, alimentícios e biomateriais.

Fumento (2003) também caracteriza o elevado impacto da biotecnologia, porém propõe uma delimitação mais específica inserindo-a na medicina e na biologia. Apesar do estabelecimento deste limite, o Autor identifica oportunidades de negócios deste segmento para a indústria farmacêutica e para o agribusiness. No caso da primeira, apresenta a possibilidade de substituição de drogas caras ou mesmo aquelas cujos agentes ativos são de difícil obtenção. Para a segunda são verificadas oportunidades de geração de sementes para a agricultura, sem a necessidade de fertilização e uso de biopesticidas, visando a proteção de culturas agrícolas utilizando organismos como bactérias e células de animais ou de vegetais. 
A economia molecular é apresentada por Meyer \& Davis (2003) como um novo ciclo econômico, desenvolvido posteriormente à economia da informação. Com nascimento claramente identificado em 1953, quando Watson \& Crick decifraram pela primeira vez a molécula de DNA, esta “nova economia” passou a desenvolver uma trajetória de ascendência de natureza semelhante à economia informacional. Neste ciclo de desenvolvimento, os Autores identificam o incremento da capacidade de compreensão das moléculas que controlam as funções químicas e biológicas resultando em um avanço significativo das ciências da vida. Ressaltam também que, de acordo com um grupo de profissionais ligados às ciências da vida na IBM, a evolução da economia molecular fará com que os biólogos substituam os físicos como os maiores usuários de supercomputadores nos próximos anos.

A abrangência deste setor e a dificuldade de estabelecimento das suas fronteiras apresentamse evidentes diante da diversidade de pesquisas que estão sendo desenvolvidas por empresas, laboratórios especializados e organizações governamentais relacionadas a este setor. Alguns dos exemplos deste tipo de pesquisa mencionados nas publicações de Fumento (2003), Meyer \& Davis (2003) e Kotler \& Simon (2004) destacam-se a abaixo:

- Elaboração de vacinas comestíveis a partir de plantas que produzem antígenos para determinados tipos de doenças como a hepatite;

- Desenvolvimento de sementes ricas em componentes importantes para a saúde humana como, por exemplo, o arroz com beta caroteno e outras vitaminas;

- Lançamento pela Unilever da margarina que reduz a taxa de colesterol aproximando os limites entre a medicina e os alimentos;

- Utilização de tecidos para monitorar sinais clínicos e vitais, desenvolvido por empresas norte-americanas, através do qual é possível identificar sinais vitais dos seres humanos assim como diagnósticos clínicos realizados na própria casa dos pacientes;

- Transmissão de dados clínicos dos seres humanos como pressão cardíaca e composição sanguínea, enviados diretamente aos laboratórios por meio da telefonia celular;

- Decodificação de perfis genéticos para habitantes de países com características menos conhecidas tais como Estônia, Tasmânia e Tailândia; 
- Emergência de biocombustíveis a partir da cana de açúcar, deslocando a discussão da escassez do petróleo para a importância do aumento de produtividade das culturas agrícolas em países em desenvolvimento como o Brasil;

- Lançamento de cosméticos que agregam valor medicinal ao resultado do seu uso, por empresas como Johnson \& Johnson, Natura e Shiseido.

Estas inovações demonstram o amplo campo de aplicações das ciências da vida e a potencialidade de seu crescimento influenciando a discussão sobre a convergência entre determinadas indústrias e o estabelecimento de novas fronteiras para a sua atuação.

Ratledge, Sasson \& Silva (1992) identificam que os limites dessa atuação são, atualmente, muito indefinidos ao demonstrarem que a biotecnologia é uma atividade industrial com alto valor agregado que abrange disciplinas como a biologia a molecular, a microbiologia, a genética, a bioquímica e, principalmente, a engenharia. Vale a pena destacar que esta última tem a potencialidade de traduzir idéias e conceitos científicos em processos viáveis de produção. Outra abordagem para a delimitação deste setor aparece em Hacking (1996), identificando fronteiras da biotecnologia com a microbiologia, bioquímica, genética e engenharia química.

Apesar desta dificuldade em definir limites, não é possível negar a abertura de novas fronteiras para o conhecimento humano e sua aplicação na produção econômica como, por exemplo, a convergência entre biologia e química, com o advento da biotecnologia, e suas aplicações em medicina e na produção de sementes geneticamente modificadas.

Wongtschowski (2002) faz uma comparação interessante do crescimento do setor de ciências da vida com outros grupos de produtos químicos - como as commodities - e observa que as empresas focadas no primeiro têm maiores índices de crescimento e rentabilidade assim como volume financeiro investido em atividades de pesquisa e desenvolvimento. Esta característica está diretamente relacionada ao significativo desenvolvimento tecnológico das últimas décadas e resulta em forte preocupação com a proteção da propriedade intelectual por meio da requisição e utilização de patentes. 
Perspectiva semelhante é encontrada nos trabalhos de Enriquez \& Goldberg (2000). Segundo estes Autores, a produção de bens e serviços para as ciências da vida tem uma perspectiva de crescimento significativa a partir da integração de diversos setores que, até então, permaneciam isolados como é o caso da indústria química, do agribusiness, da indústria farmacêutica, de saúde animal, alimentícia e de produção de energia.

Essa aproximação entre setores até então distintos gerou oportunidades de integração e reconfiguração para as organizações químicas tradicionais. Diante deste cenário, várias empresas realizaram aquisições e fusões, ou mesmo cindiram determinadas unidades de negócios. A implementação destas transações visou maximizar as condições que lhes permitiriam melhorar o seu desempenho operacional diante do incremento do seu portfolio de produtos e do aumento da margem de contribuição decorrente da atuação em mercados mais rentáveis. Estas operações encontram-se nas linhas do tempo construídas para cada uma das empresas e, entre elas, pode-se destacar:

- A aquisição da Gerber Babyfood pela Sandoz em 1994;

- A formação da Novartis em 1995 a partir da fusão das divisões farmacêutica, defensivos agrícolas, saúde animal e sementes da empresas tradicionais químics Ciba-Geigy e Sandoz, concomitante à cisão das respectivas divisões de especialidades químicas e commodities;

- A formação da Aventis a partir da fusão das divisões farmacêuticas e de agronegócio da Rhodia e Hoechst;

- O agrupamento dos negócios da área química tradicional da Monsanto sob a razão social Solutia na década de 90, passando a atuar essencialmente no negócio de ciências da vida composto por sementes e produtos farmacêuticos;

- A separação dos negócios de produtos farmacêuticos, agronegócios e sementes da ICI, formando-se a Zeneca em 1993;

- A especialização da Dupont em biotecnologia com a venda de diversas linhas produção não afinadas com esta escolha estratégica, assim como reconfiguração do seu modelo de atuação e gestão;

- A concentração e crescimento da Bayer em ciências da vida, composta por divisões de agribusiness (a partir da compra da Aventis Crop Science) e farmacêutica, separando-se das especialidades químicas; 
- Joint venture entre a Syngenta e a Dupont nos Estados Unidos, anunciada em 2006 e denominada GreenLeaf, para pesquisa e comercialização conjunta de tecnologia de milho e soja transgênica.

Uma análise detalhada da evolução estratégica do setor farmacêutico também demonstra as oportunidades de negócios intersetoriais relacionados às ciências da vida. Simon (2003) identifica os recentes movimentos das empresas farmacêuticas e os classifica em quatro categorias: integração horizontal, expansão à montante, expansão à jusante e negócios transetoriais.

\section{Quadro 4: Aquisições e fusões na indústria farmacêutica}

\begin{tabular}{|c|c|c|c|c|c|c|c|c|}
\hline \multirow{3}{*}{\multicolumn{3}{|c|}{ Integração horizontal }} & \multicolumn{3}{|c|}{ Expansão a montante } & & & \\
\hline & & & Empresas & Ano & Valor & & & \\
\hline & & & Roche / Genentech & 1990 & $2,1 \mathrm{Bi}$ & & & \\
\hline Empresas & Ano & Valor & AHP / Genetics Inst. & 1992 & $1,7 \mathrm{Bi}$ & & & \\
\hline Bristol Myers / Squibb & 1989 & $11,5 \mathrm{Bi}$ & Sandoz / Systemix & 1993 & $0,4 \mathrm{Bi}$ & & & \\
\hline SmithKline / Beecham & 1989 & $8,3 \mathrm{Bi}$ & RPR / Appl. Imm. Sc & 1993 & $0,2 \mathrm{Bi}$ & & & \\
\hline Rhône Poulenc/Rorer & 1990 & $3,8 \mathrm{Bi}$ & Cyanamid / Immunex & 1993 & $0,4 \mathrm{Bi}$ & & & \\
\hline Roche / Syntex & 1994 & $5,3 \mathrm{Bi}$ & Ciba Geigy / Chiron & 1994 & $2,1 \mathrm{Bi}$ & & & \\
\hline Sanofi / Sterling Winthrop & 1994 & $1,7 \mathrm{Bi}$ & Glaxo / Affymax & 1995 & $0,5 \mathrm{Bi}$ & & & \\
\hline AHP / Cyanamid & 1994 & $9,5 \mathrm{Bi}$ & Schering / Canji & 1996 & $0,1 \mathrm{Bi}$ & & & \\
\hline Hoechst / MMD & 1995 & $7,1 \mathrm{Bi}$ & Elan / Athena & 1996 & $0,7 \mathrm{Bi}$ & & & \\
\hline Glaxo / Wellcome & 1995 & $14 \mathrm{Bi}$ & Pharmacia / Sugen & 1999 & $0,7 \mathrm{Bi}$ & & & \\
\hline Pharmacia / Upjohn & 1995 & $7 \mathrm{Bi}$ & WL / Agouron & 1999 & $2,0 \mathrm{Bi}$ & & & \\
\hline RPR / Fisons & 1995 & $2,9 \mathrm{Bi}$ & $\mathrm{J} 8 \mathrm{~J} /$ Centocor & 1999 & $4,9 \mathrm{Bi}$ & \multirow{2}{*}{\multicolumn{3}{|c|}{ Negócios transetoriais }} \\
\hline Novartis & 1996 & $11 \mathrm{Bi}$ & Elan / Liposome & 2000 & $0,6 \mathrm{Bi}$ & & & \\
\hline Roche / Corange & 1998 & $11 \mathrm{Bi}$ & Shire / Blochem & 2000 & $4,0 \mathrm{Bi}$ & Empresas & Ano & Valor \\
\hline Aventis & 1999 & $20 \mathrm{Bi}$ & Merck / Sibia / Rosetta & 2001 & $0,7 \mathrm{Bi}$ & Sandoz / Gerber & 1994 & $3,7 \mathrm{Bi}$ \\
\hline Astra / Zeneca & 1999 & $12 \mathrm{Bi}$ & $3 \& \mathrm{~J} /$ Scios & 2003 & $2,4 \mathrm{Bi}$ & Roche / Tastemaker & 1996 & $1,0 \mathrm{Bi}$ \\
\hline Sanofi / Synthélabo & 1999 & $6 \mathrm{Bi}$ & \multirow{3}{*}{\multicolumn{3}{|c|}{$\begin{array}{c}4 \\
\text { Empresas }\end{array}$}} & DuPont / Pioneer & 1997 & $9,0 \mathrm{Bi}$ \\
\hline Abbott / Knoll (BASF) & 2000 & $6,9 \mathrm{Bi}$ & & & & Pharmacia / Monsanto & 2000 & $0,8 \mathrm{Bi}$ \\
\hline Elan / Dura & 2000 & $1,8 \mathrm{Bi}$ & & & & Roche / Givaudan & 2000 & $1,4 \mathrm{Bi}$ \\
\hline Pfizer / WL & 2000 & $1,8 \mathrm{Bi}$ & \multicolumn{2}{|c|}{ Farmacêuticas } & & Syngenta & 2000 & $8 \mathrm{Bi}$ \\
\hline Glaxo / SmithKline & 2000 & $25 \mathrm{Bi}$ & \multirow{3}{*}{\multicolumn{3}{|c|}{ Expansão a jusante }} & BASF / Wyeth & 2000 & $3,8 \mathrm{Bi}$ \\
\hline $\mathrm{J} \& \mathrm{~J} / \mathrm{Alza}$ & 2001 & $11 \mathrm{Bi}$ & & & & Bayer / Avantis CropSc. & 2001 & $6,7 \mathrm{Bi}$ \\
\hline BMS / DuPont Pharma & 2001 & $7,8 \mathrm{Bi}$ & & & & P\&G / BMS, Clairol & 2001 & $5 \mathrm{Bi}$ \\
\hline Novartis / Roche & 2001 & $2,8 \mathrm{Bi}$ & Empresas & Ano & Valor & DSM / Roche Vitamins & 2001 & $2,1 \mathrm{Bi}$ \\
\hline Roche / Chugai & 2001 & $1,5 \mathrm{Bi}$ & Merck / Medco & 1993 & $6,6 \mathrm{Bi}$ & & & \\
\hline Abbott / Vysis & 2001 & $0,4 \mathrm{Bi}$ & SB /DPS & 1994 & $2,3 \mathrm{Bi}$ & & & \\
\hline Pfizer / Pharmacia & 2002 & $48 \mathrm{Bi}$ & Lilly /PCS & 1994 & $4 \mathrm{Bi}$ & & & \\
\hline \multicolumn{3}{|l|}{ (2) } & Zeneca / Salick & 1995 & $0,2 \mathrm{Bi}$ & & & \\
\hline
\end{tabular}

Fonte: Françoise Simon SDC Group 2003 in Kotler \& Simon (2004)

As três primeiras categorias - integração horizontal, expansão à montante e à jusante apresentam-se alinhadas às categorias de estratégias para combinações empresariais apresentadas no referencial teórico deste trabalho.

No caso da integração horizontal, as fusões e aquisições são implementadas visando aumentar a participação da empresa no mercado específico daquela indústria. A expansão à montante caracteriza a aliança entre as empresas no início do processo produtivo, estabelecendo-se foco principalmente nas atividades de inovação, pesquisa e desenvolvimento. De maneira 
complementar, a expansão à jusante estabelece sinergias no final da cadeia produtiva aprimorando, dessa forma, os processos de comercialização, logística e relacionamento com os distribuidores de produtos e consumidores finais.

As oportunidades características das ciências da vida, definida como um setor em formação, aparecem na quarta categoria estratégica: os negócios transetoriais. Neste tipo de evolução das empresas, as alianças, aquisições e fusões transcendem os seus negócios originais com o objetivo de criar um empreendimento inovador que obtenha as vantagens competitivas dos setores correlatos. São identificadas oportunidades de desenvolvimento de novos mercados, de incrementar a geração de receitas e de aprimorar o desempenho operacional das empresas que se integraram para compor a nova configuração organizacional.

A concepção e implementação de estratégias das empresas do setor de ciências da vida colocam-lhes desafios de desenvolvimento de novas competências organizacionais, de reformulação dos seus modelos de gestão e de aperfeiçoamento do seu direcionamento estratégico.

Em primeiro lugar, as características específicas de setores distintos tais como produção de bens de consumo, defensivos agrícolas e produtos farmacêuticos pode tornar inviável a adoção de um único modelo organizacional pelas empresas que optaram por processo de combinação empresarial como estratégia de crescimento. Kotler \& Simon (2004) identificam especificidades em processos-chave das empresas inviabilizando a adoção de estratégias conjuntas. As diferenças nos ciclos de desenvolvimento de produtos, desde a pesquisa inicial até o lançamento para o mercado, levando a apropriação distinta de custos e conseqüente dificuldade de adoção de uma única estrutura de pesquisa. Além disso, os canais de comercialização e distribuição dos produtos podem não apresentar oportunidades de sinergia significativas, demandando a manutenção de estruturas organizacionais paralelas e, portanto, padrões elevados de custos dificultando a obtenção de vantagens competitivas para as empresas.

Outro fator relevante corresponde à aceitação de produtos híbridos, característicos deste novo setor. Apesar da perspectiva promissora da combinação entre produtos nutricionais e farmacêuticos - denominados por alguns como nutracêuticos - diante do seu alinhamento às 
preocupações recentes de qualidade de vida, houve um choque do lançamento destes produtos com os receios dos consumidores em relação aos organismos geneticamente modificados. Este receio foi alimentado pela dificuldade de comprovação científica em relação aos seus impactos à saúde humana e ao meio ambiente, reforçado pela atuação marcante de empresas voltadas para a ecologia e proteção da natureza, claramente contrárias ao desenvolvimento deste tipo de produto.

Enriquez \& Goldberg (2000) identificam estas dificuldades ressaltando o desgaste de empresas farmacêuticas que passaram a pesquisar oportunidades de inserção de medicamentos em plantas geneticamente modificadas. Apesar destas dificuldades, comprovadas pelos casos mencionados no seu artigo, os Autores projetam perspectivas positivas para este setor apoiadas principalmente no desenvolvimento de pesquisas sobre os produtos geneticamente modificados. É mencionada, entretanto, a necessidade de adoção de modelos organizacionais efetivos para a adoção bem sucedida destas estratégias de crescimento. Um exemplo ilustrativo desta diretriz de negócio é a Monsanto. A empresa, que havia feito uma fusão com a Pharmacia \& Upjohn para a formação da Pharmacia, mantém a razão social Monsanto para a subsidiária agrícola da nova companhia visando torná-la cada vez mais independente e, com isso, fortalecer as suas vantagens competitivas a partir do foco na pesquisa e produção de sementes geneticamente modificadas.

Outra tendência futura para o setor corresponde à expansão das atividades relacionadas ao desenvolvimento de biocombustíveis. Diversas pressões de caráter econômico, ambiental e político têm forçado as indústrias a utilizarem em menor escala os produtos derivados do petróleo. Diante disto, expressivo volume de recursos tem sido dispendido na pesquisa com sementes de milho e soja para a geração de enzimas que levem à obtenção destes combustíveis, com patamares elevados de performance e vantagem de custos em relação aos derivados do petróleo.

Os recursos financeiros dispendidos nesta linha de pesquisas, entretanto, tendem a gerar retornos financeiros compatíves com horizonte de longo prazo, correspondente a dez anos ou mais. A expectativa de retornos financeiros mais imediatos, manifestada pela cúpula e conselho de administradores de diversas empresas multinacionais voltadas para este setor, apresenta-se como uma ameaça para a tomada de decisão para orientação das atividades de 
pesquisa e desenvolvimento nesta direção. Entre as alternativas encontradas pelas empresas para lidar com este problema destacam-se as parcerias com Agências de Governo relacionadas, principalmente à energia e agricultura, visando captar recursos para viabilizar as pesquisas com retorno de mais longo prazo.

Os desafios de geração de novos produtos relacionados ao setor de ciências da vida, sejam eles farmacêuticos, sementes geneticamente modificadas ou enzimas para a produção de biocombustíveis, demonstram a necessidade de significativo incremento das atividades de pesquisa. Esta pressão sobre as empresas fortalece a reflexão sobre as oportunidades de aquisições e fusões, visando ampliar as plataformas e recursos destinados às atividades de pesquisa e desenvolvimento.

A análise das linhas do tempo encontradas no Apêndice A deste trabalho permite verificar o processo de entrada das empresas químicas tradicionais na composição do setor de ciências da vida como uma opção estratégica para ampliar a sua plataforma de pesquisa. Esta decisão apresenta-se motivada pela geração de vantagens competitivas no que concerne a um portfolio de produtos com margens de contribuição mais elevadas.

A observação dos diferentes casos leva à identificação de dois tipos complementares de estratégias. Em primeiro lugar, as empresas que realizaram incorporações de outras organizações menores com o objetivo de adquirir novas tecnologias sem, entretanto, modificar significativamente o seu modelo de gestão. Este tipo de estratégia pode ser exemplificado com o processo de ampliação dos negócios da DuPont, que fortaleceu a sua atuação em biotecnologia e sementes com a a aquisição da Pioneer. Esta decisão tornou a DuPont uma empresa com participação significativa nas ciências da vida sem, entretanto, influenciar as suas demais unidades focadas em materiais de performance e outras tecnologias características do seu negócio original.

Outro caso ilustrativo deste modelo de crescimento corresponde à estratégia de ampliação da Bayer em defensivos agrícolas e sementes. Visando tornar-se líder mundial neste setor, a empresa adquiriu a divisão de agribusiness da Aventis, criando uma importante unidade de negócios sem alterar o seu modelo de atuação em saúde (unidade de health care) e demais produtos químicos (unidade de material science). 
O segundo tipo de estratégia implica em profunda reformulação do modelo organizacional das empresas, especializando-as em competências essenciais específicas das ciências da vida. As decisões de desmembramento das atividades químicas tradicionais, efetivadas pelas operações de spin-off, refletem com propriedade o objetivo estratégico de foco nas atividades deste novo setor.

A formação e o desenvolvimento de duas grandes corporações - Novartis e Aventis apresentam-se como exemplos característicos deste tipo de movimento estratégico. A decisão de fusão para a formação de ambas as empresas foi efetivada juntamente com o desmembramento das atividades químicas tradicionais das empresas anteriores, as quais tornaram-se independentes. No caso da Novartis, resultado da fusão da Ciba e da Sandoz, as unidades de produtos químicos das suas empresas anteriores foram separadas do novo modelo de negócios, viabilizando uma atuação essencialmente focada em ciências da vida. No caso da Ciba, a empresa passou a atuar de maneira independente denominando-se Ciba Especialidades Químicas. Paralelamente, a Sandoz teve a sua divisão química integrada à Roche para a posterior formação da Clariant. A formação da Aventis teve natureza análoga, com a separação dos negócios de química tradicional das empresas anteriores Rhone Poulenc e Roche.

É interessante verificar, nas respectivas linhas do tempo, a continuidade do processo de especialização nestas duas empresas, manifestado em operações posteriores de spin-off. No caso da Novartis, a separação da divisão farmacêutica dos negócios de defensivos agrícolas e sementes levou à formação da Syngenta. Visando atingir o mesmo objetivo, a Aventis vendeu a sua divisão denominada Crop Science para a Bayer concentrando as suas atividades no negócio de saúde. 


\section{CAPÍTULO 6 - O ESTUdO DE CASO DO PROCESSO DE COMBINAÇÃO EMPRESARIAL}

Utilizando-se as definições apresentadas no referencial metodológico deste trabalho, foi selecionado o caso de uma empresa que realizou duas aquisições recentes nos Estados Unidos para estudo em profundidade do fenômeno de combinação empresarial e aplicação do modelo de gestão de mudança em formulação. Esta escolha deveu-se à (ao):

- Implementação das aquisições para o fortalecimento do posicionamento da empresa no setor de ciências da vida em um país com grandes oportunidades de crescimento;

- Complexidade das operações implementadas, criando significativo impacto na configuração do seu modelo organizacional global;

- Impacto das transações no mercado global de ciências da vida e no país em que ocorreram as combinações mencionadas;

- Possibilidade de obtenção de dados relevantes para a pesquisa empírica e aplicação do modelo de gestão da mudança em formulação, preservando a independência do pesquisador em relação ao objeto de pesquisa.

\subsection{Informações gerais sobre a empresa}

A organização multinacional foi denominada, para fins deste trabalho, como empresa Alfa de modo a preservar a sua identidade. Foram selecionadas informações para a compreensão do histórico da empresa, dos desafios do momento atual e dos processos de aquisição que são objeto deste estudo. É importante salientar que estas informações são de domínio público e foram coletadas em materiais de divulgação da empresa, composto por folhetos, relatórios institucionais e informes alocados no seu endereço eletrônico na internet.

A empresa é resultado de diversas fusões e aquisições entre organizações atuantes na indústria química. Ao longo da sua evolução, migrou gradativamente a sua estratégia e modelo de negócios para as ciências da vida, percebendo a oportunidade de aumento da sua lucratividade com a atuação concentrada neste setor. 
Sua matriz encontra-se na Europa e seu modelo de gestão divide-se em regiões geográficas, buscando-se adequar-se às especificidades das diversas áreas de atuação no mundo. Seu volume de negócios apresenta-se concentrado na América do Norte e na Europa, correspondendo a mais de $80 \%$ do valor total das suas operações. É importante destacar, entretanto, a atratividade de novas regiões como a América Latina e a Ásia, que apresentam perspectivas positivas para o crescimento do seu volume de negócios para o futuro.

No caso da Ásia, a atratividade está relacionada também ao deslocamento das suas operações de manufatura, buscando vantagens competitivas de custo para o estabelecimento da cadeia de supply chain nesta região. Seu desafio, nesta direção estratégica, corresponde à necessidade de captação de mão de obra local, bem como transferência de expatriados para a ampliação destas operações. No caso da América Latina, as perspectivas de crescimento encontram-se ofuscadas pela volatilidade financeira característica desta região.

A empresa Alfa vem investindo significativo volume de recursos em pesquisa e desenvolvimento para a ampliação do seu portfolio de produtos. Diante das perspectivas em ciências da vida, a empresa criou uma divisão de desenvolvimento de negócios, responsável pela identificação de novas oportunidades e implementação de novos modelos de atuação. Esta área atua de maneira complementar às demais unidades de negócios e seus projetos, focados basicamente em inovação, apresentam-se em diferentes estágios de desenvolvimento.

Seus resultados financeiros têm sido bastante positivos nos últimos anos, resultando em um crescimento do valor de suas ações superior a indicadores tradicionais de bolsa de valores como Nasdaq e Dow Jones. De acordo com os documentos da empresa, este crescimento vem sendo embasado pela estruturação de políticas e processos globais, alinhados aos padrões Sarbannes and Oxley.

Encontram-se a seguir os resultados coletados durante o processo de pesquisa, de acordo com as técnicas de levantamento e análise de dados propostas. São apresentadas as informações gerais obtidas nas entrevistas, caracterizando a perceção de profissionais de diversas áreas sobre o processo geral implementado para efetivar as aquisições analisadas. Em seguida, encontram-se os dados obtidos com a aplicação dos questionários junto aos profissionais da empresa que participaram das aquisições nos Estados Unidos. 


\subsection{Análise do material levantado nas entrevistas}

A introdução das entrevistas teve como objetivo identificar a localização de cada um dos profissionais na empresa Alfa e compreender a sua contribuição nas aquisições que foram objeto desta pesquisa. Vale a pena destacar que, de acordo com os entrevistados, as aquisições das empresas Beta e Gama foram praticamente concomitantes no ano de 2004. Não foram salientadas, portanto, diferenças significativas nos processos implementados para cada uma das duas transações, o que permitiu que os entrevistados as analisassem conjuntamente.

As informações coletadas demonstram que os executivos desempenharam dois tipos de papéis durante a combinação. Os profissionais alocados na matriz exerceram funções de coordenação da transação, respondendo por alguma área de expertise fundamental para a sua viabilização. Outro grupo de executivos com função complementar desempenhou atividades diretamente ligadas ao negócio da empresa Alfa nos Estados Unidos e teve, conseqüentemente, participação ativa na integração das empresas adquiridas ao seu modelo de operação local.

Foi relevante também entrevistar os profissionais externos à organização, que contribuiram com suporte consultivo ao processo de estruturação da combinação empresarial e participaram das entrevistas fornecendo informações com uma perspectiva externa da empresa Alfa.

A perguntas propostas no roteiro de entrevistas levaram à identificação de elementos positivos e dificuldades encontradas em cada uma das etapas do processo de combinação analisado, utilizando-se como base o modelo teórico de gestão da mudança apresentado neste trabalho.

\subsubsection{Planejamento estratégico}


No momento precedente às aquisições, havia um intento estratégico de crescimento para a empresa, que era bastante concreto e estava bastante internalizado pelos profissionais da Alfa. Eram claros, para os dirigentes da organização, os potenciais gaps na linha de negócios e no portfolio de produtos que poderiam ser obstáculos ao crescimento desejado pela empresa no médio e longo prazo.

Paralelamente aos atributos positivos de clareza e consistência do conteúdo estratégico da organização, foi também percebida, na opinião dos entrevistados, elevada eficácia na comunicação da estratégia de crescimento para os demais executivos da organização. Vale destacar a opinião de um entrevistado que mencionou a existência de um "clima de crescimento dentro da empresa diante das diversas menções às perspectivas de incremento do volume de negócios, decorrente de potenciais aquisições de outras organizações”.

Por outro lado, foi identificada uma importante necessidade de aperfeiçoamento para esta etapa do processo, não apenas relacionada às aquisições das empresas Beta e Gama mas, de maneira geral, visando preparar a organização para os desafios futuros de aquisições e fusões viabilizando o seu crescimento em ciências da vida. De acordo com as informações coletadas, havia baixa estruturação das atividades de planejamento estratégico nas diversas unidades de negócios da empresa Alfa, dificultando a elaboração de análises consistentes de gaps e oportunidades que poderiam afetar as potenciais transações de combinação.

Diante disto, a empresa criou uma área especificamente voltada para aquisições e fusões, subordinada à diretoria de desenvolvimento global de negócios, recrutando novos executivos no mercado e identificando profissionais de alto potencial alocados nas demais unidades da organização para compor este grupo. Foi destacado durante as entrevistas que esta nova área deveria passar a atuar diretamente na elaboração das atividades de planejamento estratégico das unidades de negócios que tivessem perspectivas de crescimento decorrentes de possíveis combinações empresariais.

\subsubsection{Prospecção de oportunidades}


O processo de identificação de oportunidades no mercado, com o rastreamento de potenciais empresas para combinação relacionadas à estratégia de crescimento da organização, ocorreu de maneira consistente na opinião dos executivos entrevistados. Este trabalho foi desempenhado pelos profissionais da área de aquisições e fusões recentemente criada, composta por profissionais considerados muito competentes pela empresa.

O ponto de destaque deste momento do processo foi, portanto, o alto nível de expertise técnica dos executivos envolvidos na análise de oportunidades e na proposição de projetos com modelos e técnicas avançadas de avaliação de empresas.

Foi identificada por alguns entrevistados, entretanto, uma característica que poderia vir a dificultar a ambiciosa estratégia de crescimento formulada pela organização: a excessiva aversão ao risco financeiro e operacional, decorrente da experiência de aquisições mal implementadas. Esta resistência tornou-se evidente diante dos diversos obstáculos colocados pelo Comitê Diretivo da empresa para considerar uma oportunidade de aquisição atraente e viável.

\subsubsection{Avaliação de oportunidades}

De acordo com as definições da área de aquisições e fusões da empresa, a identificação de uma oportunidade concreta deveria levar à estruturação de um projeto, com o objetivo de avaliar a empresa alvo e, posteriormente, estruturar a proposta de compra.

Para isso, foi adotado pela empresa um modelo de trabalho de equipes, composto por três grupos - Decisor, Core Team e Especialistas - conforme demonstra a figura a seguir. 


\section{Quadro 5: Estrutura de grupos implementada nas transações analisadas}

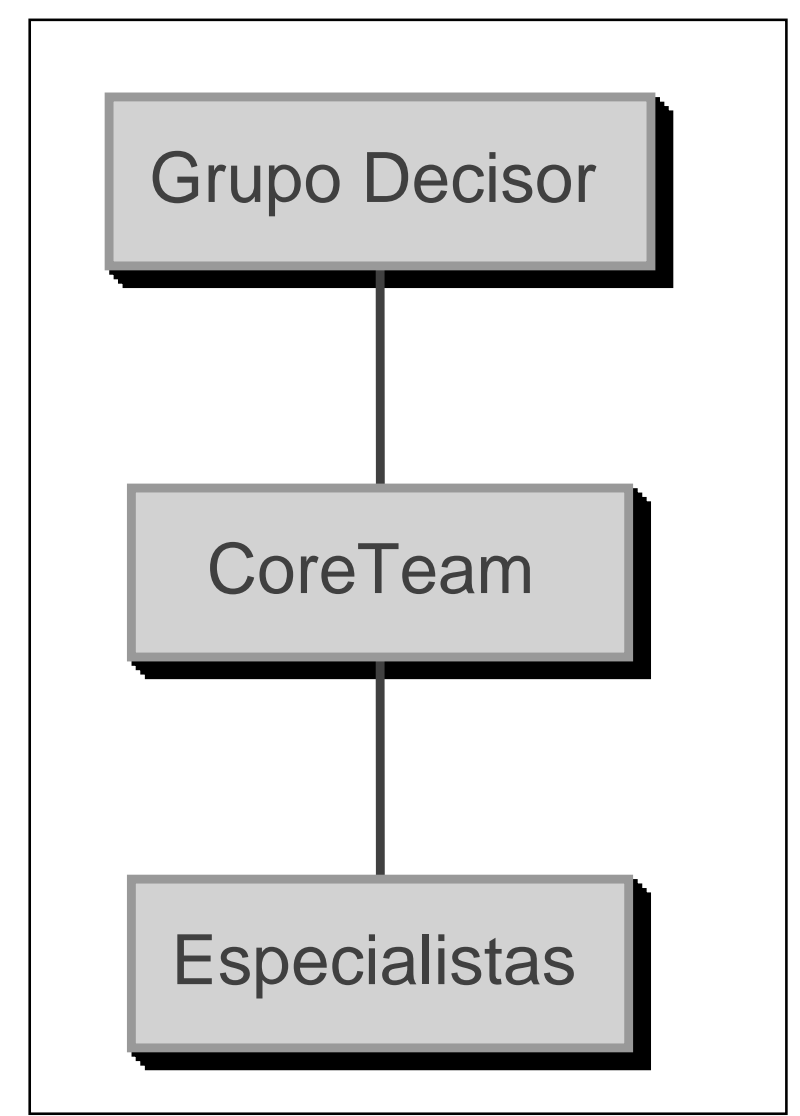

Fonte: documentos da empresa Alfa
Pôde-se perceber, nas entrevistas realizadas, um consenso na opinião dos profissionais em relação ao papel e responsabilidade que cada um destes grupos deveria exercer ao longo do projeto estruturado para a aquisição das empresas Beta e Gama.

De acordo com os entrevistados, o Core Team deveria gerenciar o processo como um todo, responsabilizando-se pelo alcance dos resultados de negócios propostos com as aquisições.

A tomada de decisão e negociação com os representantes das empresas a serem adquiridas também faria parte do escopo de atribuições e responsabilidades deste grupo.

Além disso, este grupo seria responsável pela alocação adequada dos recursos humanos envolvidos na transação e atuação conjunta com os demais integrantes do modelo de gestão adotado: o Grupo Decisor e os Especialistas.

Ao longo da transação, caberia portanto ao Core Team mapear os momentos importantes para a participação e tomada de decisões estratégicas por parte do Grupo Decisor. Paralelamente, deveria analisar as expertises requeridas para efetivar a operação, identificando a disponibilidade de especialistas no interior da empresa Alfa, ou mesmo em empresas de consultoria existentes no mercado.

Segundo os entrevistados, o Grupo Decisor deveria atuar em um nível essencialmente estratégico, tomando as decisões em relação às diretrizes a serem seguidas durante a operação. Caberia a este grupo também revisar o posicionamento da empresa Alfa em relação à combinação, no caso de surgirem informações inesperadas sobre as empresas-alvo nos seus 
relatórios financeiros ou no seu portfolio de produtos, que modificassem os planos gerais de incorporação. Além disso, deveria aprovar decisões de caráter estratégico e, principalmente, elaborar a definição final da oferta de compra, composta pelo preço a ser pago e pelas condições adicionais da negociação referentes aos ativos a serem adquiridos. Por fim, outro papel relevante do Grupo Decisor seria a articulação com o Comitê Diretivo da Empresa Alfa, viabilizando a aprovação da decisão final de aquisição por esta instância decisória.

Paralelamente, caberia ao Grupo dos Especialistas garantir a disciplina necessária para o cumprimento das etapas previstas no projeto e, ao mesmo tempo, promover cross-fertilization entre as diferentes áreas de expertise envolvidas, potencializando os benefícios do trabalho multidisciplinar. Entre as especialidades apontadas pelos entrevistados como necessárias para a análise da empresa-alvo, destacam-se as áreas jurídica, financeira, informática, recursos humanos, logística, marketing e relações institucionais.

De acordo com os entrevistados, os profissionais alocados no projeto revelaram elevada capacidade técnica, além de análises de alta qualidade nas diversas áreas de expertise representadas pelos especialistas. Parte dos entrevistados referiu-se também ao alto padrão, exigido pelo Grupo Decisor, em relação à avaliação das informações coletadas o que levou, em alguns momentos, à significativa elevação da carga de trabalho dos executivos.

Não foram colocadas dúvidas, entretanto, em relação ao comprometimento dos profissionais envolvidos, o qual foi considerado elevado em praticamente todas as entrevistas realizadas. A queda da motivação dos integrantes do Core Team e dos Especialistas, em diversos momentos do processo, foi apontada pelos entrevistados como decorrente da falta de integração entre as diversas áreas de expertise, resultante da dificuldade de coordenação do trabalho de grupos multifuncionais e conseqüente duplicidade de esforços em vários momentos da operação.

A aversão ao risco também foi apontada pelos entrevistados nesta etapa, reforçando-a como um padrão cultural da Alfa. A necessidade de informações essencialmente detalhadas que, para alguns, fazia parte do elevado padrão de qualidade da organização imposto pelo Grupo Decisor, foi interpretada por outros como decorrente da dificuldade do Comitê Diretivo da empresa em assumir riscos. Deste padrão cultural relatado nas entrevistas, desdobraram-se conseqüências tais como a morosidade do processo decisório e a baixa tolerância a erros, as 
quais criaram barreiras para a aprendizagem individual e organizacional durante o processo de mudança.

O descontentamento de alguns entrevistados com esta característica da empresa foi expresso com a afirmação de que muitas informações coletadas e suas respectivas análises não agregaram valor para a transação. De acordo com um dos especialistas entrevistados, "as análises realizadas muitas vezes caíram em detalhes pouco significativos e de pouca importância para o projeto, prejudicando a agilidade do mesmo e baixando os níveis de comprometimento de diversos integrantes dos grupos de trabalho envolvidos”.

\subsubsection{Negociação e execução do acordo}

O ponto positivo desta etapa, refletido na opinião de praticamente todos os entrevistados, foi o comprometimento do Core Team em viabilizar a transação, apesar de todos os riscos e dificuldades encontradas até esta fase do processo. Esta colocação, bastante presente nas entrevistas, refletiu o orgulho dos profissionais com a viabilização do acordo que trouxe implicações bastante significativas para o mercado de ciências da vida nos Estados Unidos e também para o modelo de operação da empresa Alfa neste país.

Ao mesmo tempo em que esta característica positiva foi salientada, as dificuldades inerentes à operação do modelo de grupos adotado também ficaram evidentes nesta etapa do processo. A falta de clareza sobre os papéis desempenhados pelos profissionais da Alfa, na negociação com os representantes das empresas a serem adquiridas, enfraqueceu significativamente a atuação da incorporadora durante o processo de compra.

Esta indefinição de atribuições e responsabilidades específicas de cada grupo, bem como das fronteiras e relações entre eles, fez com que a negociação fosse assumida em alguns momentos pelo Core Team e em outros pelo Grupo Decisor. Diante da complexidade da transação, esta ausência de clareza prejudicou a agilidade de resposta e causou o enfraquecimento da posição da Alfa diante dos concorrentes para a aquisição das empresasalvo. 
Alguns profissionais entrevistados chegaram a manifestar um sentimento de frustração diante da desvalorização do seu trabalho. Um deles comentou que se preparou arduamente para participar da negociação utilizando noites e finais de semana em detrimento da sua vida pessoal e, no último momento, foi informado de que não participaria diretamente da negociação.

Esta frustração apareceu também nas entrevistas realizadas com os consultores externos, que se consideraram sub-utilizados neste momento da transação, diante das indefinições internas da empresa. Ficou claro nas entrevistas com os consultores externos que o contínuo deslocamento da responsabilidade pela negociação e execução do acordo criou confusões no contato e na definição do papel a ser exercido pelas empresas de consultoria.

Os termos disciplina, processo decisório e velocidade da negociação foram colocados por diversos entrevistados como critérios fundamentais para o sucesso de transações desta natureza e que, no caso estudado, atuaram como elementos que fragilizaram o possibilidade de obter os resultados inicialmente planejados.

\subsubsection{Integração pós-combinação}

Nesta etapa, o relacionamento entre o os profissionais da matriz e a equipe dedicada à integração dos negócios nos Estados Unidos demonstrou-se bastante fragilizado. Isto se evidencia diante das opiniões manifestadas pelos entrevistados da matriz, as quais divergem significativamente das opiniões dos executivos do negócio localizados neste país.

De acordo com os profissionais da matriz, havia baixa consistência nas diretrizes da integração na operação norte-americana, levando à dificuldade de captura das sinergias planejadas. Alguns profissionais também mencionaram a ausência de postura estratégica dos profissionais responsáveis pela integração entre as empresas, cuja visão focada nos problemas imediatos certamente levaria a resultados pouco satisfatórios no médio e longo prazo.

Ao ouvir a opinião dos executivos nos Estados Unidos foi possível perceber um forte sentimento de orgulho em relação aos passos já trilhados. Havia uma clara percepção da 
complexidade da integração e, segundo estes profissionais, o processo esteve sob controle desde o início, apesar das dificuldades encontradas. Um dos entrevistados salientou que "a capacidade de mobilização dos quase noventa profissionais envolvidos nos subgrupos responsáveis pela integração configura-se como um dos principais pontos positivos de todo o processo".

Outro aspecto desta dissonância correspondeu à dificuldade de alocação correta de especialistas para uma implementação efetiva da integração entre as empresas. Um exemplo concreto deste obstáculo referiu-se à atuação da área de recursos humanos, que designou um profissional sênior da matriz e outro responsável pela operação nos Estados Unidos. A indefinição de papéis e responsabilidades destes dois profissionais levou à predominância da atuação do executivo da matriz o que, segundo a opinião do profissional local, levou a decisões incorretas em relação à definição de políticas e à adoção de processos e instrumentos adequados ao novo modelo de negócios da empresa. O escasso conhecimento que os executivos da matriz tinham em relação à realidade e necessidades locais, na opinião do profissional dos profissionais dos Estados Unidos, impediam-nos de tomar decisões acertadas para implementar o novo modelo de gestão.

Uma das oportunidades de melhoria do processo de gestão da mudança, que foi apontada tanto pelos executivos da matriz como pelos localizados nos Estados Unidos, corresponde à necessidade de um planejamento da integração prévio à efetivação do acordo. De acordo com os entrevistados, várias das dificuldades encontradas na etapa de integração poderiam ter sido minimizadas diante da elaboração de diretrizes consensadas ainda na fase da due diligence e da avaliação das informações coletadas. O planejamento para a integração, portanto, ocorreu no momento errado e não foi dada prioridade necessária a esta importante atividade. Diante disto, vários novos executivos foram envolvidos no processo de integração pós-combinação sem, entretanto, estarem preparados para desempenhar este papel. É importante destacar que estas opiniões dos entrevistados não questionam a capacidade técnica dos profissionais, mas sim o seu envolvimento tardio no processo.

Entre os problemas apontados nas entrevistas, decorrentes de um planejamento inadequado para a complexidade do processo, foi apontada a imprecisão acerca do montante de capital necessário para a efetivação de algumas decisões, tais como o custo de aprimoramento da 
instalação física de determinadas fábricas para receber as novas tecnologias adquiridas, ou mesmo a necessidade de pagamento de verbas rescisórias para empregados desligados em virtude da integração das empresas. Além disso, somente nesta etapa foram detectadas incompatibilidades pontuais entre os sistemas de faturamento e as diferenças de composição da cadeia de suprimentos das diferentes empresas, o que resultou no surgimento de barreiras significativas para a operação do novo modelo de negócios.

De acordo com um dos entrevistados, “é fundamental que um plano robusto e consistente seja concebido a partir do momento em que há uma certa probabilidade do acordo ser efetivado”. Mesmo que a efetivação da transação conte com algum grau de incerteza, os esforços iniciais com o planejamento da integração são fundamentais para a futura viabilização do modelo de negócios que se pretende implementar com a combinação.

Alguns entrevistados chegaram a mencionar também a necessidade de se desenvolver uma competência organizacional inovadora, voltada diretamente para a integração de modelos de negócios e processos. Diante da relevância das aquisições para viabilizar a estratégia da crescimento da organização, a formação deste tipo de expertise seria fundamental para o desenvolvimento futuro dos negócios resultantes de operações de combinação.

\subsubsection{Elementos comuns das diversas etapas}

Um dos elementos fortemente presentes nas entrevistas foi a percepção acerca da complexidade do relacionamento estabelecido entre as pessoas e grupos participantes da transação, permeando as diversas etapas do processo. Os problemas mais evidentes foram citados nas relações entre: os profissionais da matriz e os executivos dos Estados Unidos; os integrantes do Core Team e do Grupo Decisor; os profissionais especialistas nas diferentes expertises requeridas para a viabilização do processo; e, os executivos da empresa Alfa e os consultores externos.

Estas dificuldades e desentendimentos foram acentuados pela indefinição sobre as atribuições e responsabilidades dos diversos grupos envolvidos na estrutura de equipes adotada. É importante destacar também que a inexistência de um modelo de gestão de projetos e a 
decorrente baixa capacitação dos profissionais em relação a este assunto apresentou-se como um elemento restritor de uma atuação efetiva entre os executivos do Core Team e do Grupo de Especialistas durante os momentos em que atuaram conjuntamente. O resultado desta carência manifestou-se, segundo os entrevistados, na falta de coordenação entre os profissionais de diferentes áreas de expertise e, conseqüentemente, em ineficiências e duplicidade de esforços para a realização das tarefas e atingimento dos resultados esperados.

Por outro lado, alguns pontos positivos também estiveram presentes em praticamente todo o processo de mudança. A clareza da estratégia de crescimento da empresa, permeando os diversos níveis organizacionais, apresentou-se como um dos fatores que reforçou a motivação dos profissionais e grupos envolvidos, garantindo os elevados patamares de comprometimento apresentados, mesmo nos momentos de dificuldade e stress. Os entrevistados ressaltaram a coragem da empresa em realizar transações de grande magnitude e manter uma assertiva atitude de implementação, ambas balizadas pelos objetivos de crescimento de médio e longo prazo.

Vale destacar que, em vários momentos, esta ambição estratégica foi colocada como uma questão de sobrevivência dos negócios e fortalecimento da identidade da organização. De acordo com alguns entrevistados, criou-se um sentimento compartilhado pelos profissionais correspondente a “compre ou seja comprado”, diante da atratividade dos negócios em ciências da vida e da manifestação de interesse de várias empresas do setor em novas aquisições como uma das poucas alternativas de crescimento sustentável.

\subsection{Análise dos dados obtidos nos questionários}

Os dados obtidos com os questionários fornecem elementos para a análise da etapa de integração pós-combinação do caso estudado, com base na opinião dos profissionais atuantes nas empresas que participaram do processo de combinação localizado nos Estados Unidos. 


\subsubsection{Apresentação dos resultados gerais}

Os questionários foram respondidos pelos profissionais alocados nos Estados Unidos, os quais compuseram uma amostra com pessoas provenientes das empresas Alfa, Beta e Gama, constituintes do processo de combinação. Foram enviados 1121 questionários, correspondentes ao número de profissionais mapeados. O retorno obtido foi de 871 questionários preenchidos, equivalente a 77,7\% do conjunto total.

Quase metade do grupo de respondentes - ou 42\% da população - é oriunda da Alfa, empresa que efetivou a operação de aquisição. Os demais são provenientes das empresas adquiridas, sendo 273 da empresa Beta e 189 da empresa Gama.

Os restantes 44 profissionais ingressaram na empresa estudada após o processo de combinação, quando o novo modelo organizacional já estava em fase de implantação. Estes respondentes foram mantidos na amostra estatística total utilizada, porém foram excluídos da análise específica de diferença de opinião entre os profissionais de cada uma das empresas antecessoras por não possuírem identidade com nenhuma delas.

\section{Gráfico 6: Procedência dos profissionais que compõem a população pesquisada}

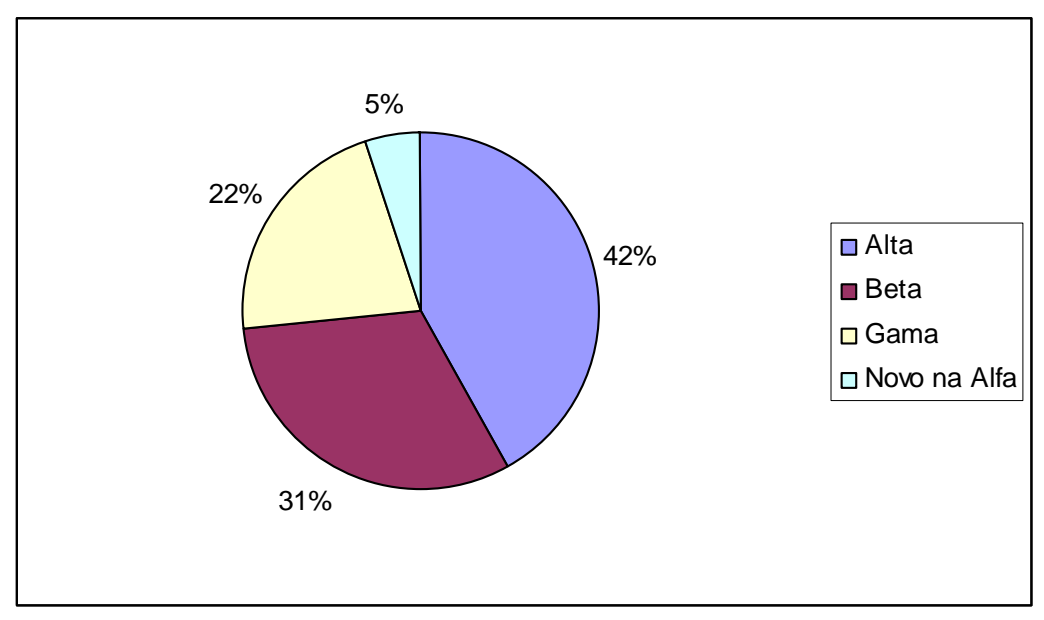

O gráfico 7 apresenta a distribuição dos respondentes de acordo com a sua alocação na estrutura organizacional implementada pela empresa Alfa após a efetivação das aquisições. Nas funções operacionais de marketing e vendas, permanece uma divisão entre as marcas das empresas anteriores, visando manter a sua identidade junto aos clientes e ao mercado. 
Verifica-se que, nesta área funcional, existe uma predominância de profissionais da marca Beta, correspondente a 18\% do total. É também elevado o número de profissionais da área de desenvolvimento de novos produtos (24\%), a qual é considerada geradora de vantagens competitivas para o setor de ciências da vida.

\section{Gráfico 7: Alocação dos respondentes}

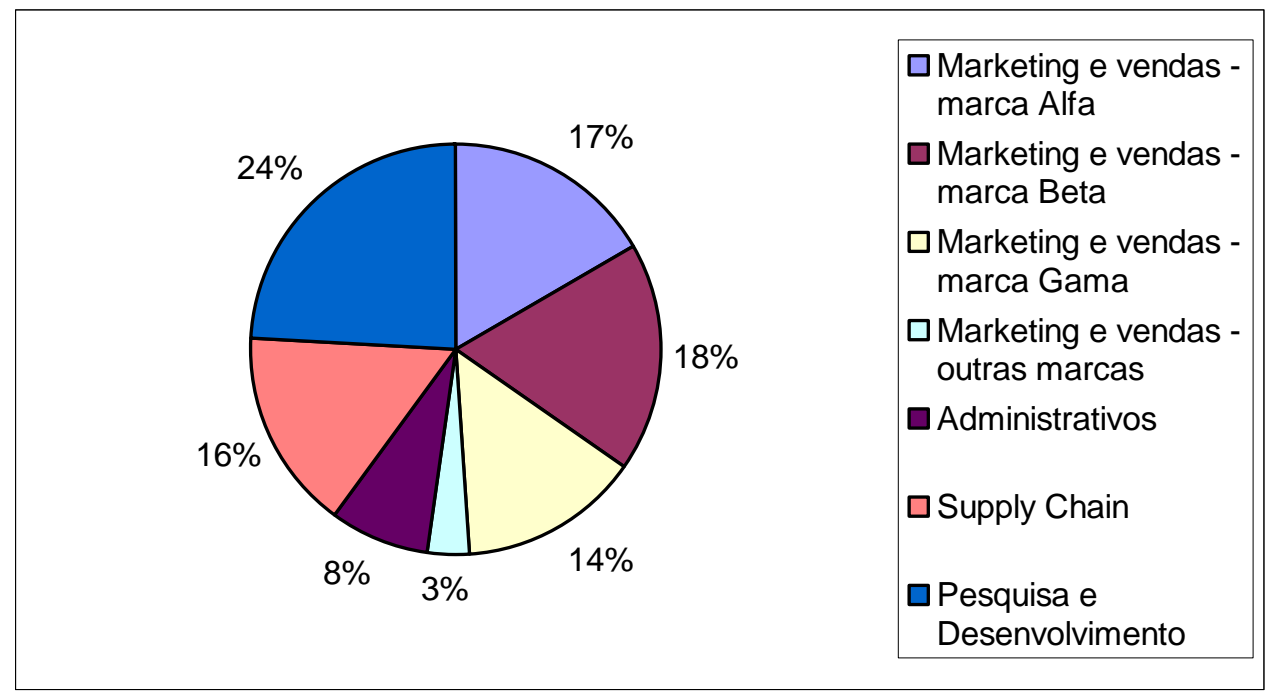

\subsubsection{Resultados da análise fatorial}

A aplicação desta técnica levou à identificação de treze distintos fatores, correspondentes a agrupamentos de variáveis a partir dos níveis de correlação que apresentaram entre si. Os dados quantitativos obtidos com este procedimento estatístico encontram-se no Apêndice E deste trabalho. Cada uma destas variáveis corresponde a uma questão do questionário, as quais foram agrupadas nas categorias propostas pelo referencial teórico.

A análise comparativa entre os agrupamentos obtidos e o modelo do referencial teórico demonstram que quase a totalidade deles - ou doze dos fatores encontrados - confirmam as categorias elaboradas inicialmente.

Foi interessante observar também a potencialidade do procedimento estatístico para aprimorar a precisão das categorias. Os níveis de correlação entre as variáveis levaram à sugestão de deslocamento de algumas variáveis para diferentes categorias. Para a observação destes 
deslocamentos, foram mantidas entre parênteses as categorias originais em que estavam alocadas estas questões.

No caso da categoria comunicação, grande parte das questões originais propostas no questionário apareceram agrupadas no mesmo fator após a aplicação do procedimento estatístico, confirmando-a como categoria para a etapa de integração pós-combinação do modelo de gestão da mudança elaborado. A redução do seu número original de variáveis para menos da metade, ou seja, de doze para cinco questões no agrupamento encontrado na análise fatorial, cria um foco específico para esta categoria. De acordo com as questões selecionadas e destacadas a seguir, o conteúdo desta categoria apresenta-se delimitado ao processo de comunicação e às mensagens enviadas ao longo da mudança organizacional implementada. As demais questões da categoria comunicação, conforme definição original do questionário, foram agrupadas em outros fatores.

\section{Questões agrupadas na categoria comunicação}

- A quantidade de comunicação recebida foi suficiente

- A comunicação tem sido passada no momento correto

- A comunicação tem sido bastante aberta

- As comunicações a respeito de mudanças na organização atenderam às minhas necessidades

- A comunicação e coordenação entre times de integração foi efetiva

As demais categorias formuladas inicialmente - visão de futuro, processo de integração e gestão de recursos humanos - tiveram uma relação direta com diversos agrupamentos obtidos na análise fatorial, viabilizando a interpretação dos mesmos com base no modelo teórico elaborado.

As questões da categoria visão de futuro tiveram relação com quatro diferentes agrupamentos, possibilitando a interpretação dos mesmos como comprometimento com a estratégia; capacidade de implementação da estratégia; conteúdo da estratégia: complementação de portfolio; e, conteúdo da estratégia: desenvlvimento de produtos. As próximas tabelas apresentam as questões correspondentes a cada um destes agrupamentos. 
- Estamos nos tornando mais inovadores

- Estamos encontrando novos e melhores caminhos para fazer as coisas

- Estou confiante em relação à nossa competitividade na indústria

\section{Questões do fator capacidade de implementação da estratégia}

- Tenho confiança na capacidade de implementação da estratégia de todo o meu time funcional

- Tenho confiança na minha capacidade de implementação da estratégia

- Tenho confiança na capacidade de implementação da estratégia do time de liderança da minha função

- Tenho confiança na capacidade de implementação da estratégia do time de liderança da empresa

\section{Questões do fator conteúdo da estratégia: complementação de portfolio}

- Conheço as razões que fazem as aquisições da empresa Alfa gerarem valor para os acionistas

- Considero boa a idéia de implementar uma estratégia de complementação de portfolio

- As decisões tomadas até o momento suportam a estratégia de complementação de portfolio elaborada

- Conheço e compreendo a estratégia de aquisições da empresa

\section{Questões do fator conteúdo da estratégia: desenvolvimento de produtos}

- Estou otimista em relação à habilidade da empresa para introduzir a estratégia de complementação de portfolio com a diferenciação requerida

- Estou otimista em relação à habilidade da empresa para gerar produtos sob demanda

- Estou otimista em relação à habilidade da empresa para gerar novos produtos com alta performance

- Estou otimista em relação à habilidade da empresa para produzir e entregar os produtos no tempo adequado

De maneira análoga à visão de futuro, foi possível estabelecer uma relação entre a categoria processo de integração e quatro dos agrupamentos de variáveis obtidos com a análise 
estatística, os quais foram interpretados como atuação do time de integração; energia dos profissionais para a integração; obtenção de sinergias; e, agilidade da integração.

\section{Questões do fator atuação do time de integração}

- Eu soube quem pertence ao meu time de integração e o seu conjunto de atribuições e responsabilidades

- O time de integração relacionado à minha função foi efetivo e comunicativo

- O time de integração relacionado à minha função teve os recursos necessários para implementar com o sucesso a integração

- Há consistente planejamento para as atividades de integração previstas para os próximos meses

\section{Questões do fator energia dos profissionais para a integração}

- A carga de trabalho durante o processo de integração foi passível de gerenciamento.

- Os processos e procedimentos estão evoluindo de acordo com as estratégias estabelecidas (visão de futuro)

\section{Questões do fator integração e sinergia}

- Conheço as metas de integração para a sinergia de custos

- Considero as metas de sinergia de custos consistentes e passíveis de serem alcançadas

\section{Questões do fator agilidade da integração}

- As decisões-chave relacionadas à localização do site de desenvolvimento de produtos foram tomadas no tempo adequado

- As decisões-chave relacionadas à localização do site de manufatura da empresa foram tomadas no tempo adequado

- As principais decisões relacionadas à gestão de recursos humanos foram tomadas no momento correto (gestão de recursos humanos)

- As decisões-chave relacionadas à integração foram tomadas no tempo adequado

- As decisões-chave relacionadas à localização do escritório central da empresa foram tomadas no tempo adequado

- O processo de integração do negócio tem sido justo e objetivo

- Soube da minha situação profissional na empresa o mais breve possível (comunicação) 
A identificação de uma relação com os fatores também foi verificada com o conteúdo da categoria gestão de recursos humanos. A partir da análise dos agrupamentos de variáveis, foi possível interpretá-los como ocupação das posições na nova organização; retenção de profissionais; e, gestão de remuneração e benefícios.

\section{Questões do fator ocupação das posições na nova organização}

- O processo de integração de recursos humanos tem sido justo e objetivo

- O processo de entrevistas para as novas posições foi bem organizado e gerenciado de maneira apropriada

- O processo de aplicação para novas posições foram bem organizado e gerenciado apropriadamente

- As informações relacionadas às posições que ficariam disponíveis na minha area foram bem organizadas e gerenciadas de maneira apropriada

- O tratamento dispensado aos profissionais que não receberam posições na nova organização foi justo e respeitoso

\section{Questões do fator retenção dos profissionais}

- Ações relacionadas à retenção de profissionais-chave estão sendo implementadas durante a integração

- A empresa continuará a reter profissionais-chave nos próximos seis meses

- Os meus pares estão satisfeitos com a integração até o momento (processo de integração)

- Até o momento a integração tem sido um sucesso (processo de integração)

\section{Questões do fator gestão de remuneração e benefícios}

- Eu mudei de posição durante a integração e os termos aplicados foram apropriados

- Tive respostas adequadas para as perguntas relacionadas à gestão de remuneração

- Eu fui realocado para um novo site da organização durante a integração e os termos foram satisfatórios

- A implementação da folha de pagamento e administração de benefícios foi bem sucedida 
Entre os treze agrupamentos de variáveis identificados na análise fatorial, um deles demonstrou a possibilidade de formulação de uma nova categoria para a etapa de integração pós-combinação do modelo de gestão da mudança, a qual não foi identificada originalmente no referencial teórico. Ele agrega questões inicialmente alocadas nas categorias visão de futuro, comunicação e integração, conforme apresenta a tabela a seguir.

\section{Questões agrupadas na nova categoria identificada com a análise fatorial}

- Conheço as expectativas em relação à minha atuação para a implementação da estratégia (visão de futuro)

- Eu compreendo as metas operacionais da minha função (comunicação)

- As expectativas em relação à minha atuação são consistentes (visão de futuro)

- Estou começando a me identificar com a minha função na nova organização (comunicação)

- Eu compreendo as metas financeiras da minha função (comunicação)

- Meu gestor tem sido claro quanto às mudanças decorrentes da integração e as suas causas (comunicação)

- Meus pares estão começando a se identificar com a suas funções na nova organização (comunicação)

- Meu gestor apóia o processo de integração (processo de integração)

- Conheço a nova estrutura organizacional, assim como as atribuições e responsabilidades das pessoas que atuam na minha área (processo de integração)

- Meu gestor manteve-me informado a respeito dos planos de integração que me afetariam (comunicação)

- Acredito que pertenço a um time vencedor (visão de futuro)

- Sabemos qual é a visão de futuro e quais são os caminhos para atingí-la (visão de futuro)

- Os empregados têm neste momento energia suficiente para tornar a integração um sucesso (processo de integração)

A análise fatorial trouxe dois tipos de contribuições importantes para o refinamento do modelo de gestão da mudança nas combinações empresariais. A primeira delas corresponde à confirmação das categorias propostas inicialmente no referencial teórico do trabalho. Além de confirmá-las, foi possível identificar oportunidades de melhoria em cada uma delas, a partir 
do deslocamento de variáveis entre diferentes categorias, incrementando a precisão do modelo.

A segunda contribuição da análise fatorial consiste na identificação de uma nova categoria, a qual não foi proposta inicialmente no referencial teórico. A análise do conteúdo das questões alocadas neste novo agrupamento apresenta elementos essencialmente ligados à relação estabelecida entre os profissionais e a nova empresa.

De acordo com estas questões, a relação dos profissionais com a nova empresa é resultante de dois elementos-chave. O primeiro é a compreensão dos elementos relacionados à sua atuação no novo modelo organizacional. Neste caso, são consideradas as questões correspondentes ao conhecimento e à concordância dos respondentes com as expectativas que a empresa tem do seu desempenho. Este conteúdo estava originalmente alocado na categoria visão de futuro.

O segundo elemento corresponde às questões que expressam a identificação dos profissionais com os atributos operacionais das suas novas atribuições e responsabilidades. Destacam-se, neste caso, as questões relacionadas respectivamente ao conhecimento das metas operacionais e financeiras da nova posição dos respondentes.

É interessante observar também o impacto do relacionamento estabelecido pelo profissional com os seus pares e gestor no balizamento da sua relação com a nova empresa. De acordo com a tabela apresentada, três questões agrupadas nesta categoria mencionam a atuação do gestor. A primeira delas corresponde à clareza do gestor na comunicação das mudanças para os profissionais envolvidos, variável que foi inicialmente alocada na categoria comunicação. A segunda questão, também agrupada originalmente em comunicação, identifica o papel do gestor na informação dos membros da sua equipe sobre os planos de integração que podem afetá-los. Por fim, a terceira questão menciona o nível de suporte do gestor ao processo de integração como um todo, definida como parte do processo de integração no modelo de categorias inicialmente proposto. A relação com os pares, de maneira complementar, manifesta-se no nível de identificação dos mesmos com as suas novas posições, originalmente presente na categoria comunicação. 
A análise das questões agrupadas nesta nova categoria sugere a sua denominação como clareza de expectativas. Seu conteúdo remete à importância desta clareza entre a empresa e os profissionais envolvidos nos processos de combinação empresarial, gerando impactos positivos no comprometimento dos mesmos com o desempenho da nova organização. Algumas variáveis, também agrupadas neste fator de acordo com os resutados da análise estatística, refletem características positivas da adesão das pessoas ao processo de mudança implementado com transações de combinação empresarial. Verifica-se que o sentimento dos profissionais como pertencentes a um time vencedor, o conhecimento da visão de futuro assim como dos caminhos para atingí-la e a existência de energia suficiente para tornar a integração um sucesso também aparecem como variáveis desta nova categoria.

A pesquisa bibliográfica realizada para a constituição do referencial teórico deste trabalho e a aplicação da análise fatorial às variáveis contidas no instrumento de levantamento de dados utilizado fornecem insumos relevantes para a elaboração do modelo de gestão de mudança em combinações empresariais.

Diante da confirmação das categorias iniciais pela análise fatorial, decidiu-se pela sua adoção na configuração final da etapa de integração pós-combinação. É importante ressaltar que foram incorporadas as oportunidades de refinamento identificadas, tais como os deslocamentos de algumas variáveis entre as categorias apresentadas anteriormente. Foi incorporada ao modelo também a nova categoria proposta e interpretada com clareza de expectativas.

A tabela a seguir destaca este processo evolutivo, apresentando o modelo teórico formulado incialmente, a interpretação dos treze agrupamentos obtidos com a análise fatorial e a proposição final de categorias. 
Tabela 7: Evolução das categorias propostas para a etapa de integração pós-combinação

\begin{tabular}{|c|c|c|}
\hline Modelo teórico inicial & $\begin{array}{l}\text { Interpretação dos agrupamentos } \\
\text { obtidos com a análise fatorial }\end{array}$ & 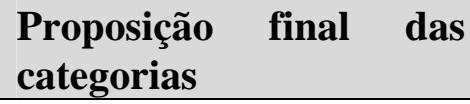 \\
\hline Comunicação & Comunicação & Comunicação \\
\hline \multirow{4}{*}{ Visão de futuro } & Comprometimento com a estratégia & \multirow{4}{*}{ Visão de futuro } \\
\hline & $\begin{array}{l}\text { Capacidade de implementação da } \\
\text { estratégia }\end{array}$ & \\
\hline & $\begin{array}{l}\text { Conteúdo da estratégia: } \\
\text { complementação de portfolio }\end{array}$ & \\
\hline & $\begin{array}{l}\text { Conteúdo da estratégia: } \\
\text { desenvolvimento de produtos }\end{array}$ & \\
\hline \multirow{3}{*}{$\begin{array}{l}\text { Gestão de recursos } \\
\text { humanos }\end{array}$} & $\begin{array}{l}\text { Ocupação das posições na nova } \\
\text { organização }\end{array}$ & \multirow{3}{*}{$\begin{array}{l}\text { Gestão de recursos } \\
\text { humanos }\end{array}$} \\
\hline & Retenção de profissionais & \\
\hline & Gestão de remuneração e benefícios & \\
\hline \multirow{4}{*}{ Processo de integração } & Atuação do time de integração & \multirow{4}{*}{ Processo de integração } \\
\hline & $\begin{array}{l}\text { Energia dos profissionais para a } \\
\text { integração }\end{array}$ & \\
\hline & Integração e sinergia & \\
\hline & Agilidade da integração & \\
\hline & Clareza de expectativas & Clareza de expectativas \\
\hline
\end{tabular}

O próximo passo para o refinamento do modelo consiste na análise de consistência destas novas categorias, utilizando-se a técnica fundamentada no coeficiente de Alfa de Crombach, cujas especificações técnicas encontram-se no referencial metodológico deste trabalho.

\subsubsection{Resultados da análise de consistência}

Os coeficientes de confiabilidade de cada uma das categorias propostas são apresentados na tabela a seguir. São considerados os dois enfoques propostos no referencial metodológico 
deste trabalho, ou seja, (1) com os dados originais e (2) com os dados omissos e "não sei" imputados como a mediana dos demais valores. Os dados quantitativos desta análise são encontrados no Apêndice D deste trabalho.

Tabela 8: Coeficientes de confiabilidade para as categorias propostas

\begin{tabular}{|c|c|c|}
\hline \multirow[t]{2}{*}{ Categorias } & \multicolumn{2}{|c|}{ Alfa de Crombach } \\
\hline & Dados originais & Dados imputados \\
\hline Visäao de futuro (15 questões) & $\begin{array}{c}0,8755 \\
(n=539)\end{array}$ & $\begin{array}{c}0,8676 \\
(n=871)\end{array}$ \\
\hline Comunicação (6 questões) & $\begin{array}{c}0,9087 \\
(n=267)\end{array}$ & $\begin{array}{c}0,8601 \\
(n=871)\end{array}$ \\
\hline Processo de integração (14 questões) & $\begin{array}{c}0,9024 \\
(n=229)\end{array}$ & $\begin{array}{c}0,8627 \\
(n=871)\end{array}$ \\
\hline Gestão de recursos humanos (12 questões) & $\begin{array}{l}0,8917 \\
(\mathrm{n}=65)\end{array}$ & $\begin{array}{c}0,8289 \\
(n=871)\end{array}$ \\
\hline Clareza de expectativas (14 questões) & $\begin{array}{c}0,9194 \\
(n=448)\end{array}$ & $\begin{array}{c}0,9128 \\
(n=871)\end{array}$ \\
\hline
\end{tabular}

Esta tabela demonstra que, em geral, a confiabilidade foi boa para todas as categorias, com valores de Alfa sempre acima de 0,80. Em algumas situações, a análise sugere que uma das variáveis seja excluída visando aumentar o valor de Alfa, conforme demonstrado a seguir.

Tabela 9: Proposta de exclusão de variáveis das categorias

\begin{tabular}{|l|c|c|c|c|}
\hline \multirow{2}{*}{ Categorias } & \multicolumn{2}{|c|}{ Dados originais } & \multicolumn{2}{c|}{ Dados imputados } \\
\cline { 2 - 5 } & Var. excluída & $\begin{array}{c}\text { Acréscimo no } \\
\text { alfa }\end{array}$ & Var. excluída & $\begin{array}{c}\text { Acréscimo no } \\
\text { alfa }\end{array}$ \\
\hline Visão de futuro & nenhuma & - & nenhuma & - \\
\hline Comunicação & nenhuma & - & $12 \mathrm{~F}$ & 0,0182 \\
\hline $\begin{array}{l}\text { Processo de } \\
\text { integração }\end{array}$ & nenhuma & - & nenhuma & - \\
\hline $\begin{array}{l}\text { Gestão de } \\
\text { recursos humanos }\end{array}$ & $14 \mathrm{E}$ & 0,0139 & $14 \mathrm{E}$ & 0,0046 \\
\hline $\begin{array}{l}\text { Clareza de } \\
\text { expectativas }\end{array}$ & nenhuma & - & nenhuma & - \\
\hline
\end{tabular}


A eliminação das variáveis destacadas na tabela anterior, e o conseqüente acréscimo do valor de Alfa, aumenta a confiabilidade das categorias. Optou-se, portanto, pela exclusão do item 14E na categoria Gestão de RH e 12F na categoria Comunicação. Diante da implementação destas decisões, a tabela a seguir apresenta o detalhamento das categorias, com respectivas questões e análise de consistência, da etapa de integração pós-combinação do modelo de gestão de mudança formulado.

Tabela 10: Questões e análise de consistência para as categorias da etapa de integração pós-combinação

\begin{tabular}{|c|c|c|c|}
\hline \multirow[t]{2}{*}{ Categorias } & \multirow[t]{2}{*}{ Questões } & \multicolumn{2}{|c|}{ Alfa de Crombach } \\
\hline & & Dados originais & Dados imputados \\
\hline Visão de futuro & $\begin{array}{c}\text { 22E, 22B, 22C, 8C, 8D, 8B, } \\
8 \mathrm{~A}, 4 \mathrm{C}, 4 \mathrm{D}, 4 \mathrm{~A}, 4 \mathrm{~B}, 6 \mathrm{C}, 6 \mathrm{~B}, \\
6 \mathrm{~A}, 6 \mathrm{D}\end{array}$ & $\begin{array}{l}0,8755 \\
(n=539)\end{array}$ & $\begin{array}{c}0,8676 \\
(n=871)\end{array}$ \\
\hline Comunicação & 12A, 12B, 12C, 12D, 12E & $\begin{array}{c}0,9087 \\
(n=267)\end{array}$ & $\begin{array}{c}0,8783 \\
(n=871)\end{array}$ \\
\hline $\begin{array}{l}\text { Processo de } \\
\text { integração }\end{array}$ & $\begin{array}{c}10 \mathrm{E}, 10 \mathrm{~F}, 10 \mathrm{D}, 10 \mathrm{C}, 10 \mathrm{G} \\
10 \mathrm{~A}, 18 \mathrm{E}, 22 \mathrm{~F}, 16 \mathrm{G}, 16 \mathrm{H}, \\
\text { 16A, 16B, 16C, 16D }\end{array}$ & $\begin{array}{l}0,9024 \\
(n=229)\end{array}$ & $\begin{array}{c}0,8627 \\
(n=871)\end{array}$ \\
\hline $\begin{array}{l}\text { Gestão de recursos } \\
\text { humanos }\end{array}$ & $\begin{array}{c}14 \mathrm{C}, 14 \mathrm{~B}, 14 \mathrm{~A}, 16 \mathrm{E}, 18 \mathrm{C} \\
18 \mathrm{D}, 18 \mathrm{~B}, 18 \mathrm{~A}, 14 \mathrm{D}, 14 \mathrm{~F}, \\
14 \mathrm{G}\end{array}$ & $\begin{array}{l}0,9056 \\
(n=65)\end{array}$ & $\begin{array}{l}0,8335 \\
(n=871)\end{array}$ \\
\hline $\begin{array}{l}\text { Clareza de } \\
\text { expectativas }\end{array}$ & $\begin{array}{c}20 \mathrm{~A}, 20 \mathrm{C}, 20 \mathrm{~B}, 18 \mathrm{~F}, 20 \mathrm{D} \\
20 \mathrm{E}, 18 \mathrm{G}, 16 \mathrm{I}, 16 \mathrm{~F}, 12 \mathrm{E} \\
22 \mathrm{D}, 22 \mathrm{~A}, 10 \mathrm{H}, 18 \mathrm{H}\end{array}$ & $\begin{array}{l}0,9194 \\
(n=448)\end{array}$ & $\begin{array}{c}0,9128 \\
(n=871)\end{array}$ \\
\hline
\end{tabular}

\subsection{Análise da integração pós-combinação}

A análise da etapa de integração entre as empresas Alfa, Beta e Gama foi realizada com base nos dois testes de hipóteses formulados no referencial metodológico deste trabalho. Em primeiro lugar, foi analisado o nível de desenvolvimento da abordagem de gestão de mudança implementada na transação, de acordo com opinião dos profissionais que responderam o questionário. Em seguida, foi verificado se havia existência de diferença significativa de opinião entre os profissionais provenientes das três empresas participantes da transação, fornecendo elementos para a elaboração de estratégias customizadas às necessidades dos diferentes grupos. 
O modelo de gestão da mudança formulado neste trabalho, com as categorias refinadas para a etapa de integração pós-combinação, fornece uma estrutura consistente para esta análise, a partir do estabelecimento das seguintes questões diretrizes.

\section{Tabela 11: Questões diretrizes para a análise da integração pós-combinação}

\begin{tabular}{|l|l|}
\hline Categorias & Questões diretrizes para o teste de hipóteses \\
\hline Visão de futuro & $\begin{array}{l}\text { Foi elaborada uma visão orientadora de futuro para os } \\
\text { profissionais que participaram da operação? }\end{array}$ \\
\hline Comunicação & $\begin{array}{l}\text { Foi estruturado um processo de comunicação interna junto } \\
\text { aos diversos públicos envolvidos na combinação } \\
\text { empresarial? }\end{array}$ \\
\hline Processo de integração & $\begin{array}{l}\text { Houve consistência na integração das políticas, processos e } \\
\text { instrumentos de gestão, viabilizando pleno funcionamento } \\
\text { do novo modelo de negócios estabelecido? }\end{array}$ \\
\hline Gestão de recursos & $\begin{array}{l}\text { Foram elaboradas e implementadas políticas e práticas de } \\
\text { recursos humanos, alinhadas às necessidades da nova } \\
\text { organização? }\end{array}$ \\
\hline Clareza de expectativas & $\begin{array}{l}\text { Foi estruturado um processo de mudança no qual houve } \\
\text { clareza de expectativas entre a empresa e os profissionais } \\
\text { envolvidos? }\end{array}$ \\
\hline
\end{tabular}

Conforme detalhado no referencial metodológico deste trabalho, a análise do nível de desenvolvimento da abordagem de gestão da mudança implementada foi elaborada com base em medidas-resumo para cada uma das categorias propostas. Além disso, o conteúdo de cada uma das variáveis - ou questões do instrumento de levantamento de dados utilizado apresenta-se como elemento facilitador de uma integração efetiva entre as empresas.

Para fins da análise estatística, a identificação destes elementos facilitadores foi investigada considerando-se a concordância dos integrantes do grupo em relação à sua existência na 
abordagem de gestão de mudança implementada. Assim, foi testado se as medidas-resumo encontradas foram maiores ou iguais a 3, configurando-se as seguintes hipóteses:

- $\mathrm{H}_{0}$ - medida-resumo da categoria maior ou igual a 3 (expressando concordância)

- $\mathrm{H}_{1}$ - medida-resumo da categoria menor do que 3 (expressando discordância)

Para identificar a existência de diferença na opinião dos profissionais provenientes das empresas Alfa, Beta e Gama, foi o elaborado o teste de hipóteses apresentado a seguir.

- $\mathrm{H}_{0}$ - há igualdade entre a opinião dos profissionais das três empresas

- $\mathrm{H}_{1}$ - há diferença entre a opinião dos profissionais das três empresas

No caso de rejeição de hipótese nula, são testadas as diferenças entre os pares de empresas, ou seja, (1) existência de diferença significativa de opinião entre os profissionais de Alfa e Beta, (2) diferença entre Alfa e Gama e (3) diferença entre Beta e Gama.

As hipóteses dos dois testes formulados - nível de desenvolvimento da abordagem e diferença de opinião dos profissionais - foram testadas com um nível de significância de 5\%. É importante salientar, entretanto, que em amostras com grande número de observações, pequenas diferenças nas médias são consideradas significantes demandando, portanto, julgamento do pesquisador para a confirmação ou rejeição das hipóteses formuladas.

Apresenta-se na sequência uma página com o sumário dos resultados quantitativos obtidos para cada uma das categorias. Estes sumários relatam os dados de estatística descritiva, os resultados dos testes de hipóteses e as conclusões para cada uma das categorias, utilizando-se as questões diretrizes propostas anteriormente. 


\subsubsection{Visão de futuro}

\begin{tabular}{lccccc}
\hline Estatística descritiva & $\mathrm{N}$ & Média & EP & \multicolumn{2}{c}{ I.C. (95\%) } \\
\hline Total & 869 & 3,125 & 0,014 & 3,098 & 3,152 \\
\hline Empresa Alfa & 365 & 3,087 & 0,021 & 3,046 & 3,128 \\
Empresa Beta & 273 & 3,086 & 0,023 & 3,041 & 3,131 \\
Empresa Gama & 189 & 3,221 & 0,032 & 3,158 & 3,284 \\
\hline
\end{tabular}

\begin{tabular}{ll}
\hline Testes de hipóteses & p-valor \\
\hline Nível de desenvolvimento da abordagem de gestão da mudança & $>0,999$ \\
\hline Igualdade de opinião entre os profissionais das três empresas & $<0,001$ \\
Igualdade de opinião entre Alfa e Beta & $>0,999$ \\
Igualdade de opinião entre Alfa e Gama & $<0,001$ \\
Igualdade de opinião entre Beta e Gama & $<0,001$ \\
\hline
\end{tabular}

\section{Conclusões}

Aceita-se a hipótese de concordância dos respondentes em relação à elaboração de uma visão orientadora de futuro para os profissionais que participaram da operação ( $p>0,999$ ).

Rejeita-se a hipótese de igualdade de opinião entre os profissionais provenientes das três empresas em relação à visão de futuro $(\mathrm{p}<0,001)$. Não há diferença significante entre as empresas Alfa e Beta ( $>>0,999)$. Há um nível significativamente maior de concordância por parte das pessoas da empresa Gama, conforme demonstra o gráfico de intervalos de confiança abaixo.

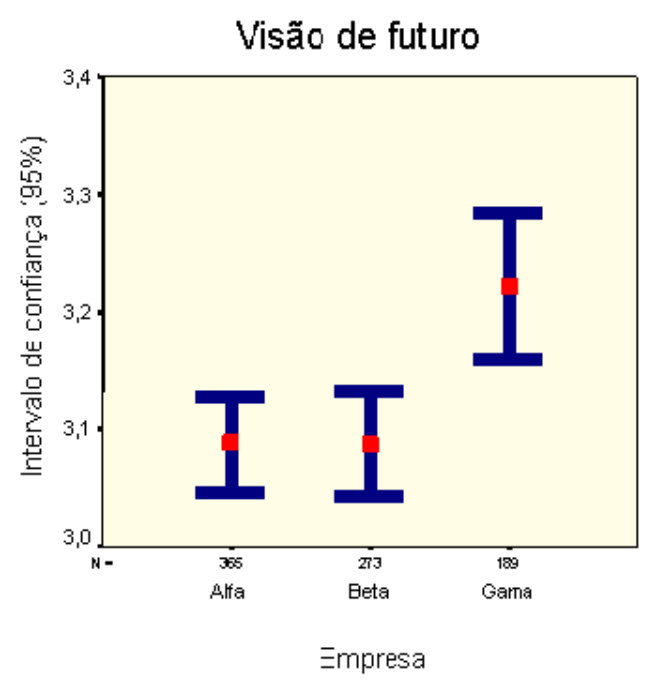




\subsubsection{Comunicação}

\begin{tabular}{lccccc}
\hline Estatística descritiva & $\mathrm{N}$ & Média & EP & \multicolumn{2}{c}{ I.C. (95\%) } \\
\hline Total & 866 & 2,861 & 0,020 & 2,822 & 2,900 \\
\hline Empresa Alfa & 365 & 2,881 & 0,030 & 2,822 & 2,940 \\
Empresa Beta & 273 & 2,827 & 0,035 & 2,758 & 2,896 \\
Empresa Gama & 189 & 2,860 & 0,047 & 2,768 & 2,952 \\
\hline
\end{tabular}

\begin{tabular}{ll}
\hline Testes de hipóteses & p-valor \\
\hline Nível de desenvolvimento da abordagem de gestão da mudança & $<0,001$ \\
\hline Igualdade de opinião entre os profissionais das três empresas & 0,523 \\
\hline
\end{tabular}

\section{Conclusões}

Rejeita-se a hipótese de concordância dos respondentes em relação à existência de um processo de comunicação interna junto aos diversos públicos envolvidos na combinação empresarial $(\mathrm{p}<0,001)$.

Aceita-se a hipótese de que há igualdade entre a opinião dos profissionais provenientes das diferentes empresas em relação à comunicação $(p=0,523)$. O gráfico abaixo demonstra que as médias de opinião dos profissionais encontram-se bastante próximas.

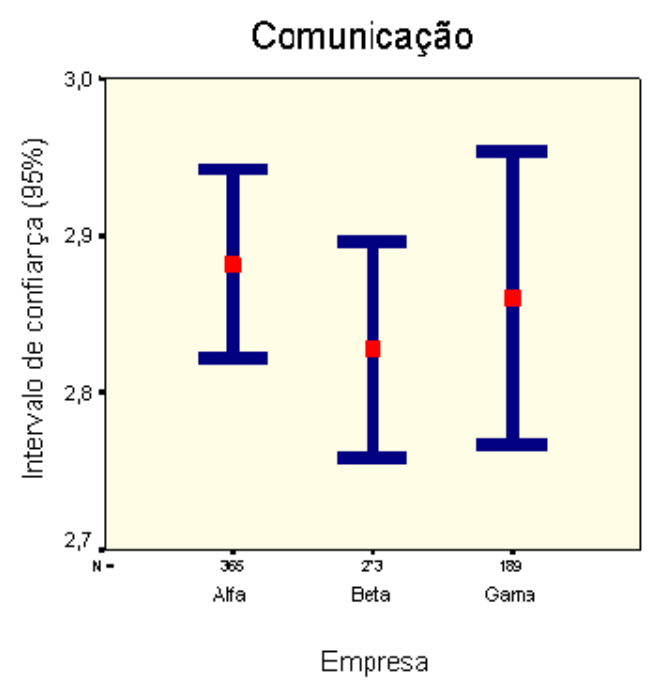




\subsubsection{Processo de integração}

\begin{tabular}{llllll}
\hline Estatística descritiva & $\mathrm{N}$ & Média & EP & \multicolumn{2}{c}{ I.C. (95\%) } \\
Total & 870 & 2,694 & 0,015 & 2,665 & 2,723 \\
\hline Empresa Alfa & 365 & 2,674 & 0,024 & 2,627 & 2,721 \\
Empresa Beta & 273 & 2,697 & 0,028 & 2,642 & 2,752 \\
Empresa Gama & 189 & 2,727 & 0,032 & 2,664 & 2,790 \\
\hline \multicolumn{7}{l}{ Testes de hipóteses } & \multicolumn{3}{c}{ p-valor } \\
\hline Nível de desenvolvimento da abordagem de gestão da mudança & \multicolumn{2}{c}{$<0,001$} \\
\hline Igualdade de opinião entre os profissionais das três empresas & & \multicolumn{2}{c}{0,421} \\
\hline
\end{tabular}

\section{Conclusões}

Rejeita-se a hipótese de concordância dos respondentes em relação à consistência da integração das políticas, processos e instrumentos de gestão na nova organização, viabilizando o pleno funcionamento do novo modelo de negócios estabelecido $(\mathrm{p}<0,001)$.

Aceita-se a hipótese de que há igualdade entre a opinião dos profissionais das empresas em relação ao processo de integração $(p=0,421)$. O gráfico a seguir demonstra que as médias de opinião dos profissionais encontram-se bastante próximas.

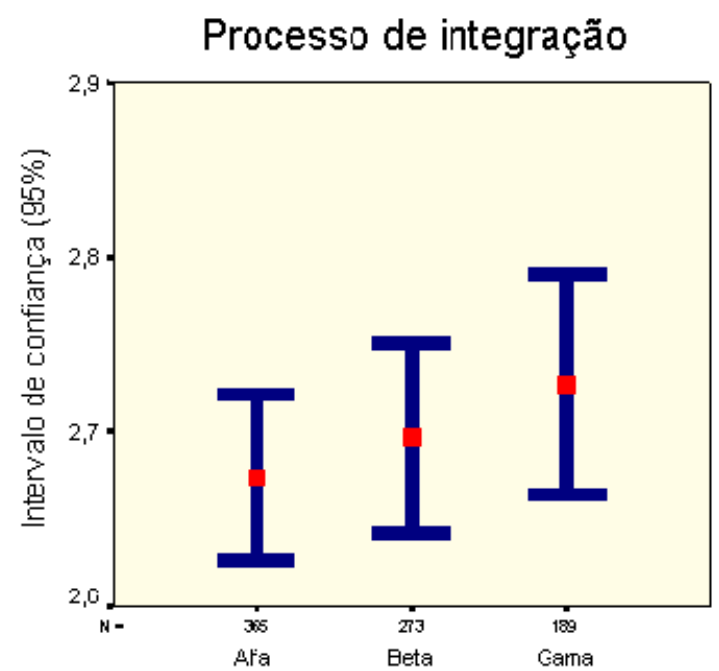

Empresa 


\subsubsection{Gestão de recursos humanos}

\begin{tabular}{|c|c|c|c|c|c|}
\hline \multirow{2}{*}{$\begin{array}{l}\text { Estatística descritiva } \\
\text { Total }\end{array}$} & \multirow{2}{*}{$\begin{array}{c}\mathrm{N} \\
861\end{array}$} & \multirow{2}{*}{$\begin{array}{c}\text { Média } \\
2,786\end{array}$} & \multirow{2}{*}{$\begin{array}{c}\mathrm{EP} \\
0,016\end{array}$} & \multicolumn{2}{|c|}{ I.C. $(95 \%)$} \\
\hline & & & & 2,755 & 2,817 \\
\hline Empresa Alfa & 361 & 2,827 & 0,025 & 2,778 & 2,876 \\
\hline Empresa Beta & 271 & 2,664 & 0,029 & 2,607 & 2,721 \\
\hline Empresa Gama & 188 & 2,864 & 0,032 & 2,801 & 2,927 \\
\hline \multicolumn{4}{|l|}{ Testes de hipóteses } & \multicolumn{2}{|c|}{ p-valor } \\
\hline \multicolumn{4}{|c|}{ Nível de desenvolvimento da abordagem de gestão da mudança } & \multicolumn{2}{|c|}{$<0,001$} \\
\hline \multicolumn{4}{|c|}{ Igualdade de opinião entre os profissionais das três empresas } & \multicolumn{2}{|c|}{$<0,001$} \\
\hline \multicolumn{4}{|c|}{ Igualdade de opinião entre Alfa e Beta } & \multicolumn{2}{|c|}{$<0,001$} \\
\hline \multicolumn{3}{|c|}{ Igualdade de opinião entre Alfa e Gama } & & \multicolumn{2}{|c|}{0,647} \\
\hline \multicolumn{3}{|c|}{ Igualdade de opinião entre Beta e Gama } & & \multicolumn{2}{|c|}{$<0,001$} \\
\hline
\end{tabular}

\section{Conclusões}

Rejeita-se a hipótese de que existe concordância em relação à elaboração e implementação de políticas e práticas de recursos humanos, alinhadas às necessidades da nova organização $(\mathrm{p}<0,001)$.

Rejeita-se a hipótese de igualdade de opinião entre os profissionais provenientes das três empresas em relação à gestão de recursos humanos $(\mathrm{p}<0,001)$. Não há diferença estatisticamente significante de opinião entre os profissionais das empresas Alfa e Gama ( $p=0,656)$. Há um nível significativamente menor de concordância por parte dos profissionais da empresa Beta, conforme demonstra o gráfico a seguir.

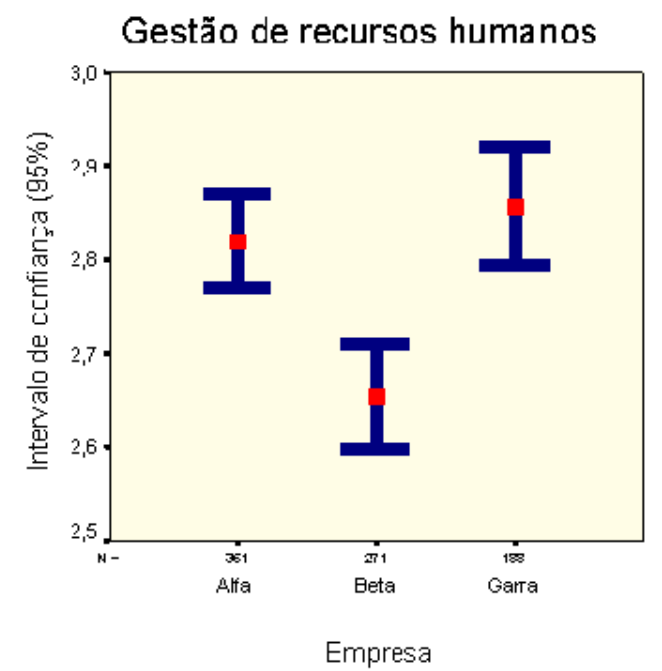




\subsubsection{Clareza de expectativas}

\begin{tabular}{lccccc}
\hline Estatística descritiva & $\mathrm{N}$ & Média & EP & \multicolumn{2}{c}{ I.C. (95\%) } \\
\hline Total & 870 & 2,960 & 0,017 & 2,927 & 2,993 \\
\hline Empresa Alfa & 365 & 2,975 & 0,026 & 2,924 & 3,026 \\
Empresa Beta & 273 & 2,898 & 0,028 & 2,843 & 2,953 \\
Empresa Gama & 189 & 3,000 & 0,036 & 2,929 & 3,071 \\
\hline
\end{tabular}

\begin{tabular}{lc}
\hline Testes de hipóteses & p-valor \\
\hline Nível de desenvolvimento da abordagem de gestão da mudança & 0,0087 \\
\hline Igualdade de opinião entre os profissionais das três empresas & 0,051 \\
\hline
\end{tabular}

\section{Conclusões}

Rejeita-se a hipótese de concordância em relação à estruturação de um processo de mudança para a combinação entre as empresas, no qual houve clareza de expectativas entre a empresa e os profissionais $(\mathrm{p}=0,0087)$.

Aceita-se a hipótese de que há igualdade entre a opinião dos profissionais das empresas em relação à clareza de expectativas $(\mathrm{p}=0,051)$. O gráfico de intervalo de confiança a seguir demonstra que as médias de opinião dos profissionais encontram-se próximas. Vale a pena ressaltar, entretanto, que p-valor para este teste de hipótese encontra-se muito próximo do valor de 5\% e que, conforme o gráfico a seguir, a menor média encontra-se na empresa Beta.

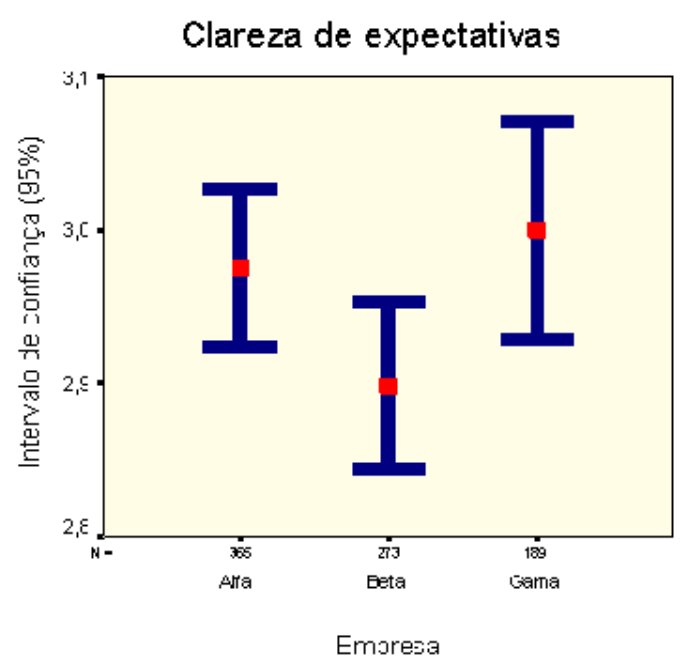


Para ilustração dos resultados dos testes de hipóteses, foram selecionadas as questões do instrumento de levantamento e elaborado um panorama da opinião dos respondentes utilizando-se os seguintes critérios: (1) os pontos mais altos de concordância, todos com percentual de respostas concordantes acima de $75 \%$ e (2) discordância, com respostas discordantes sempre acima de $20 \%$ do total. Foram selecionados também comentários qualitativos relevantes, expressos pelos profissionais ao longo do preenchimento dos questionários.

Utilizando estes critérios, foi possível observar que há alto nível de compreensão e confiança dos respondentes em relação à estratégia e visão de futuro elaborada pela empresa Alfa para realizar a aquisição da Beta e Gama. Mais de $90 \%$ das pessoas da amostra pesquisada conhecem e compreendem a estratégia de aquisições da empresa, enquanto que mais de 85\% dos profissionais declaram conhecer as razões que farão as aquisições gerarem valor futuro para os acionistas da empresa Alfa.
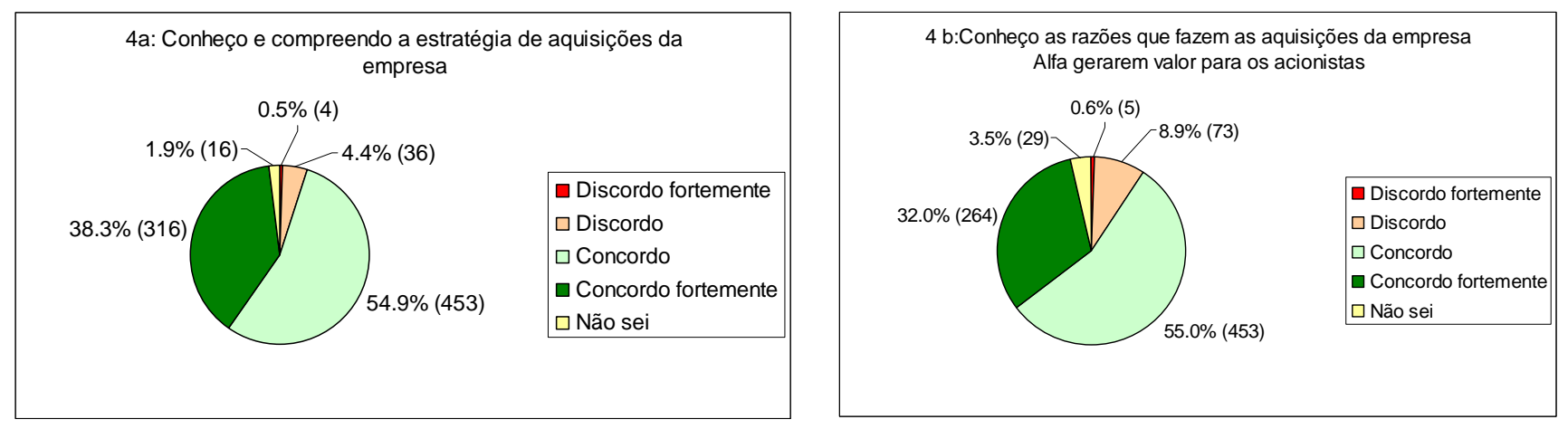

Os profissionais demonstram-se confiantes também com o potencial da estratégia formulada pela empresa Alfa. O gráfico a seguir mostra que mais de $85 \%$ da amostra pesquisada acreditam na estratégia de complementação de portfolio da organização, a qual levou à aquisição das empresas Beta e Gama. A confiança na visão de futuro também é expressa no otimismo dos profissionais em relação à geração de novos produtos com alta performance e sob demanda para o mercado (respectivamente $90 \%$ e $80 \%$ do total da amostra). 

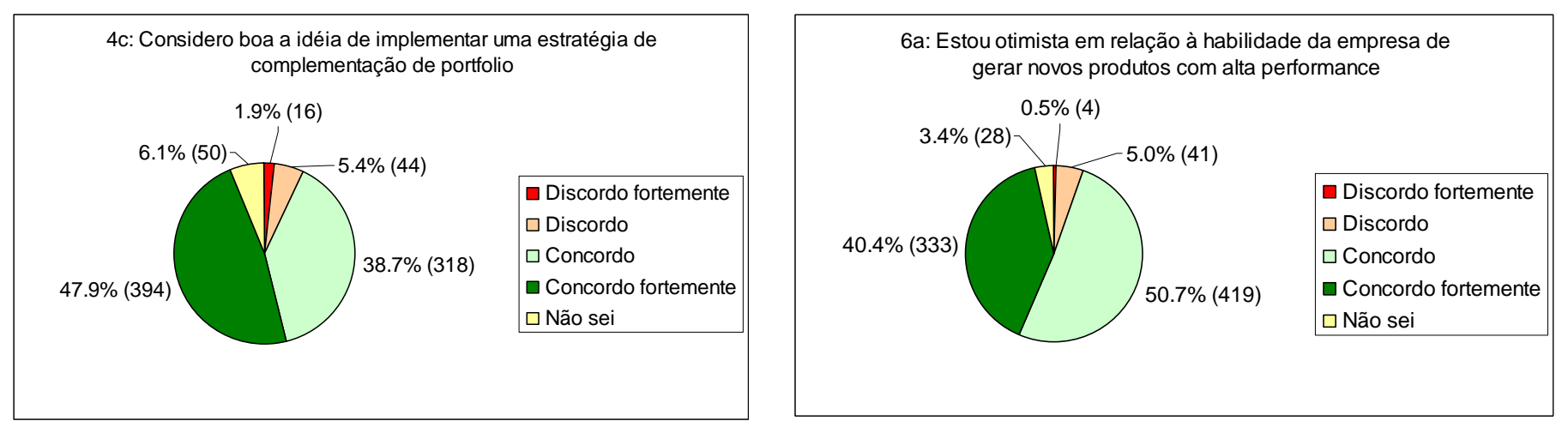

6b: Estou otimista em relação à habilidade da empresa de gerar produtos sob demanda

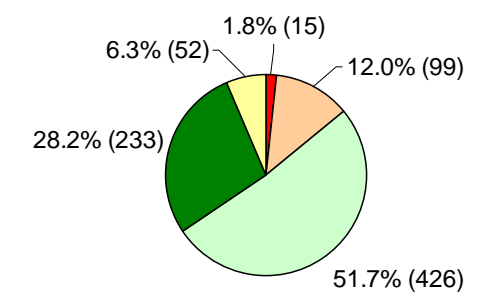

$\square$ Discordo fortemente

$\square$ Discordo

$\square$ Concordo

$\square$ Concordo fortemente

$\square$ Não sei

Os indicadores positivos também podem ser observados com a opinião dos profissionais sobre a capacidade da empresa Alfa em implementar a estratégia concebida. Os níveis de credibilidade demonstrados pelos respondentes, entretanto, aparecem distintos quando são comparados os resultados obtidos com as quatro questões relacionadas ao tema. Os gráficos a seguir demonstram estas diferenças de opinião, com base em quatro questões distintas capacidade de implementação da estratégia pela liderança da empresa, pela liderança da função, pelo time funcional e pelos próprios respondentes - respectivamente com índices crescentes de concordância.

8a: Tenho confiança na capacidade de implementação da estratégia do time de liderança da empresa.

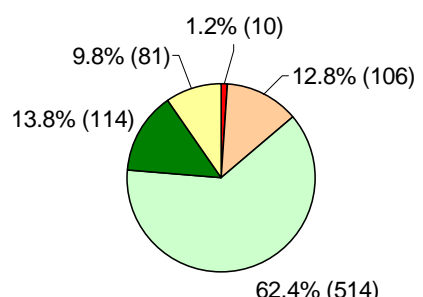

$\square$ Discordo fortemente

$\square$ Discordo

$\square$ Concordo

$\square$ Concordo fortemente

$\square$ Não sei

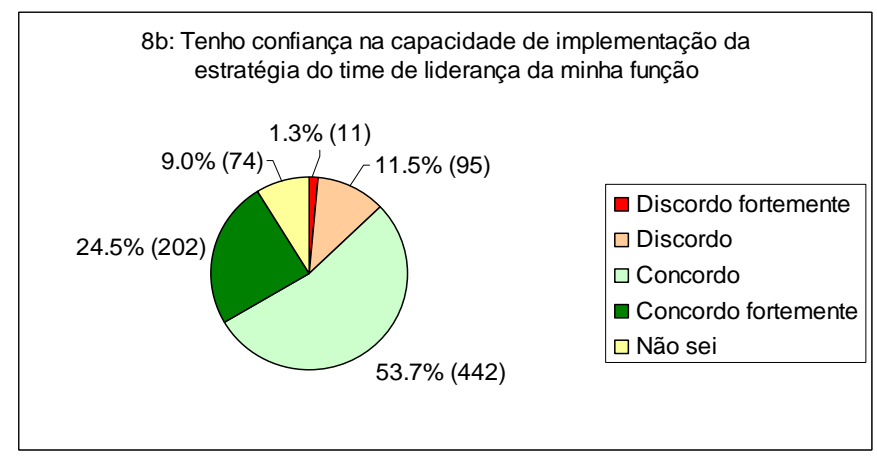



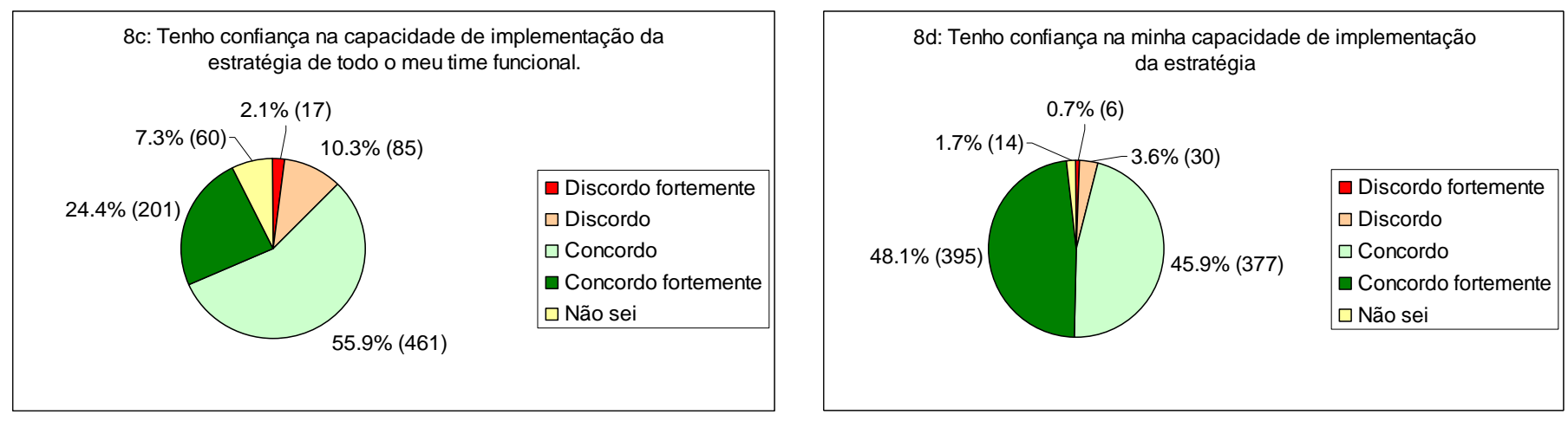

É importante destacar, entretanto, que dois itens da categoria visão de futuro apresentam-se como fonte de preocupação, gerando necessidade de intervenção diante do seu potencial impacto negativo nos resultados empresariais futuros. De acordo as respostas obtidas com os questionários, quase 30\% dos respondentes está preocupado com a capacidade da empresa em diferenciar no mercado as três marcas adquiridas, criando um posicionamento confuso das mesmas para os clientes. Além disso, há receio por parte de $25 \%$ dos profissionais quanto à cadeia de suprimentos, manifestando dúvidas em relação à habilidade da empresa para produzir e entregar os produtos no tempo adequado para os clientes.
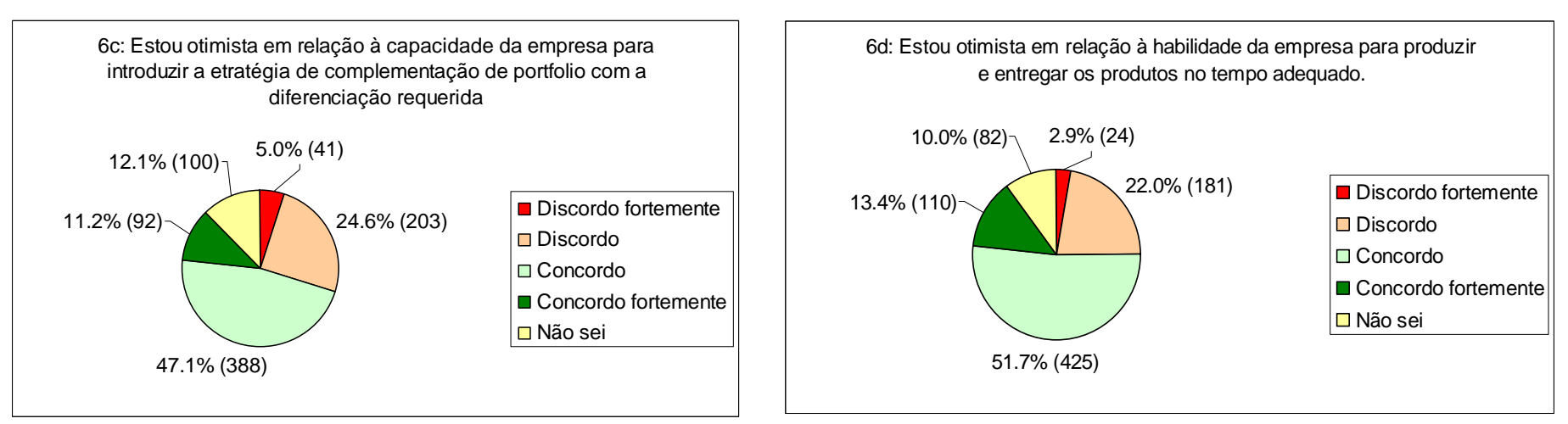

De qualquer forma, há forte crença de que a empresa Alfa está caminhando na direção correta, com uma estratégia robusta para fazer frente aos desafios futuros característicos do setor de ciências da vida e com boa capacidade de implementação da mesma para a geração dos resultados esperados. Estes comentários são reforçados pelos resultados de outra variável presente no questionário. De acordo com o próximo gráfico, mais de $75 \%$ dos respondentes têm confiança em relação à competitividade da empresa na sua indústria. 


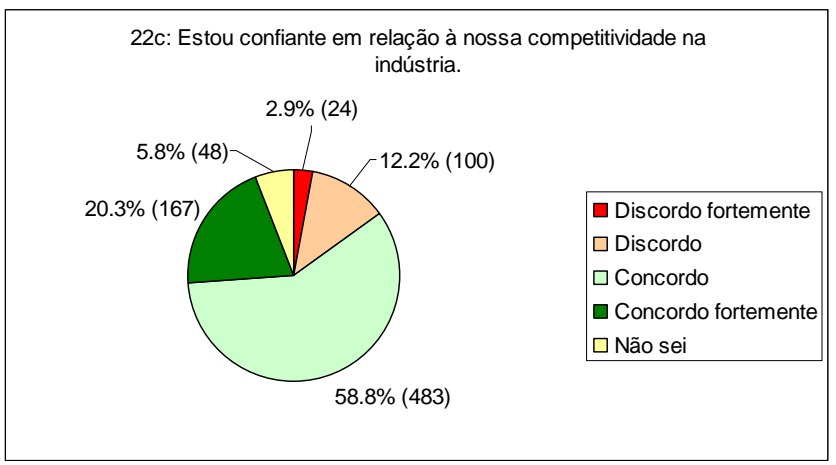

O mesmo cenário positivo, entretanto, não aparece nas demais categorias relacionadas à gestão do processo de mudança das aquisições das empresas Beta e Gama. Iniciando esta reflexão pela comunicação interna, observa-se que mais de 25\% da amostra expressa discordância em relação ao timing em que as informações foram comunicadas e também desconforto frente à adequação destas às suas necessidades no momento da integração. De maneira complementar, verifica-se que mais de $25 \%$ dos respondentes discordam que a comunicação das mudanças organizacionais satisfez as suas necessidades e quase 24\% deles discordam da adequação da quantidade de informações disseminada pelos canais de comunicação estabelecidos pela empresa.
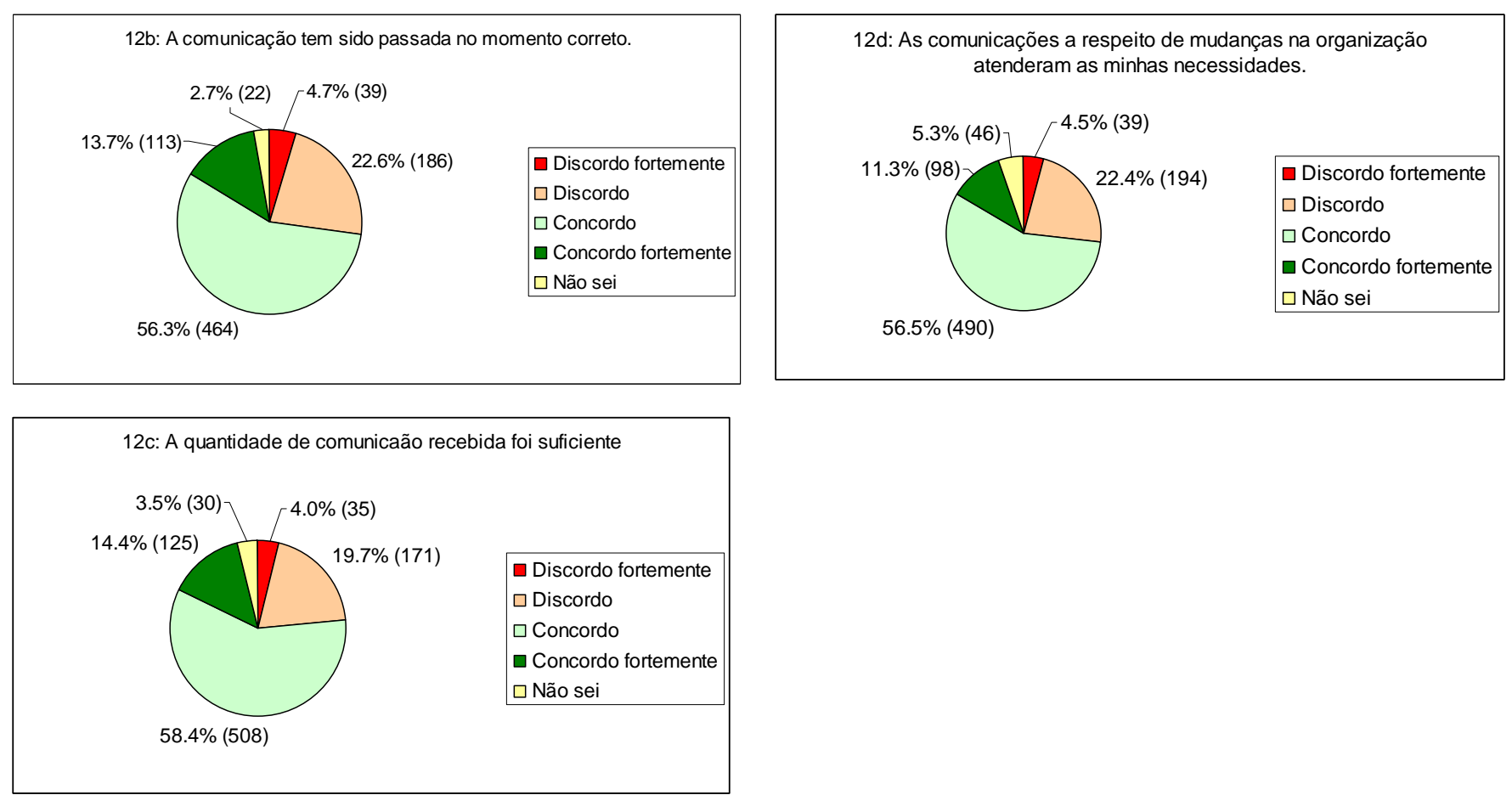
Um comentário qualitativo que chama a atenção é “a comunicação das decisões relacionadas à integração das empresas começou bem, porém teve sua quantidade significativamente diminuída como a evolução do processo” ou, conforme colocado por outro respondente, “seria importante ter um processo consistente de comunicação do processo de integração para todos os departamentos, garantindo que os profissionais estivessem na mesma página (on the same page)”.

Além disso, o processo de integração como um todo foi considerado moroso. De acordo com um comentário selecionado, “algumas vezes os anúncios de nomeação das pessoas ou definições em relação aos sites são atrasados mesmo depois da decisão já ter sido tomada”. O gráfico a seguir demonstra quase 33\% de discordância em relação ao timing da tomada de decisões em relação à integração das empresas.

10c: As decisões-chave relacionadas à integração foram tomadas no tempo adequado.

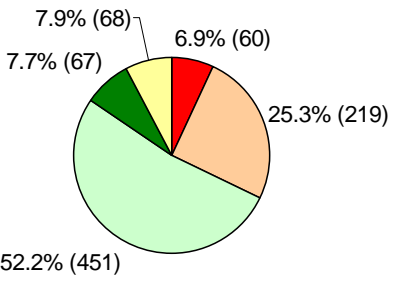

$\square$ Discordo fortemente

$\square$ Discordo

$\square$ Concordo

$\square$ Concordo fortemente

$\square$ Não sei

Aplicando esta mesma linha de raciocínio às questões de recursos humanos, verifica-se que 35\% da amostra discorda da adequação do momento em que foram tomadas as decisões relacionadas à gestão de pessoas. Vale a pena destacar também que quase $25 \%$ dos respondentes não concordam com a objetividade e justiça do processo de integração de recursos humanos.
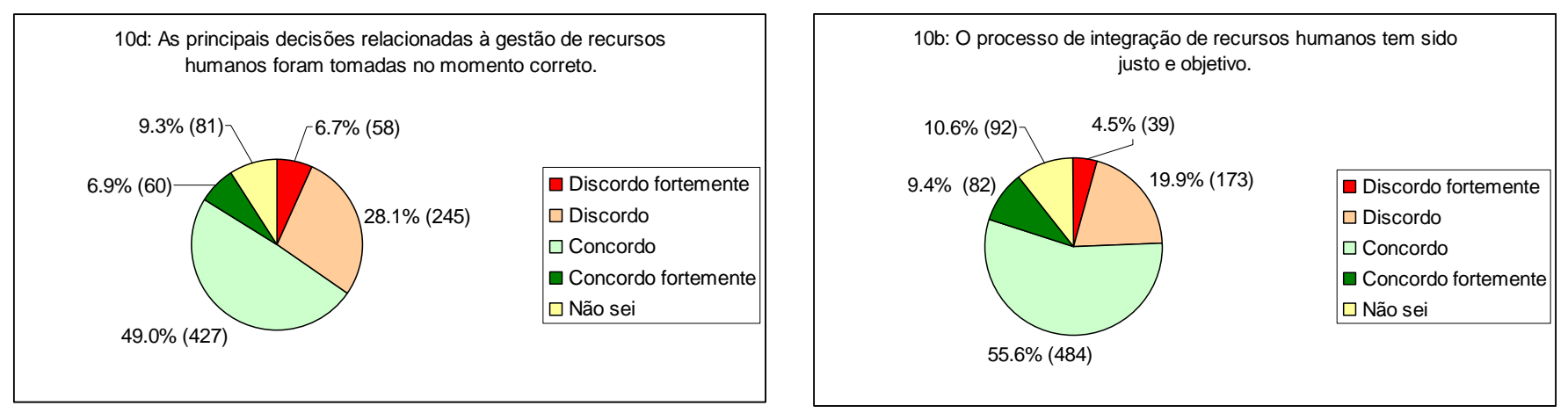
Outro elemento de preocupação destacado pelo grupo que respondeu os questionários corresponde à remuneração. Mais de 25\% destes profissionais tiveram dificuldade para a resolução das suas dúvidas em relação à compensação durante o processo de integração. Vale a pena mencionar o comentário qualitativo de um profissional, caracterizando a "não habilidade da empresa Alfa em disponibilizar informações sobre salários aos empregados durante a integração...pior ainda foi o fato da área de RH não disponibilizar as faixas salariais aos profissionais e raramente retornar as minhas ligações”.

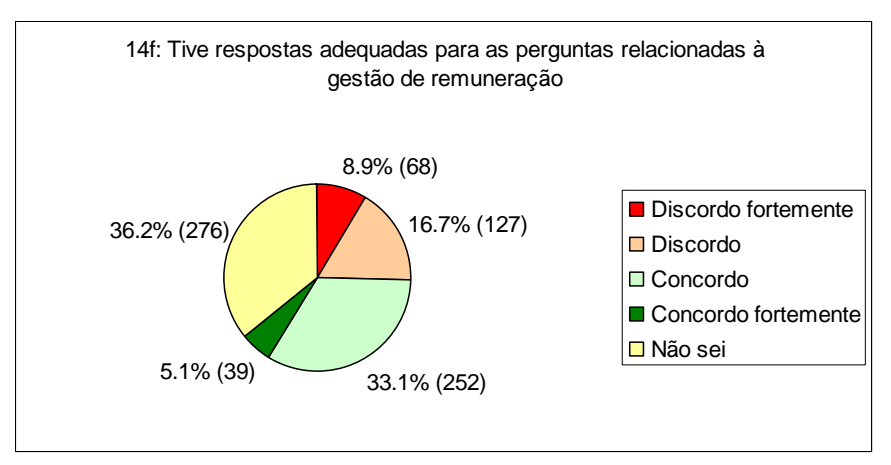

Este ponto aparece presente também na discussão sobre as oportunidades de carreira para os profissionais no novo modelo organizacional, criado após as aquisições. Dois comentários qualitativos do mesmo respondente demonstram claramente esta questão. "Se comparados aos profissionais da empresa Alfa, os profissionais da empresa Beta e Gama não receberam uma quantidade semelhante de promoções e avanços na carreira...a empresa Alfa criou caminhos e alternativas para colocar os seus profissionais nas posições criadas, mesmo quando não qualificados para tais desafios”.

As preocupações relacionadas à remuneração e às oportunidades de carreira na organização geram um impacto imediato na satisfação dos respondentes em relação à habilidade da nova empresa em reter os profissionais-chave durante a integração. Verifica-se abaixo que mais de $35 \%$ dos profissionais não concordam que ações de retenção estão sendo implementadas efetivamente pela organização. Vale a pena observar também que quase 30\% dos integrantes do grupo que respondeu o questionário acreditam que a organização não conseguirá reter os profissionais que deseja nos próximos seis meses. 

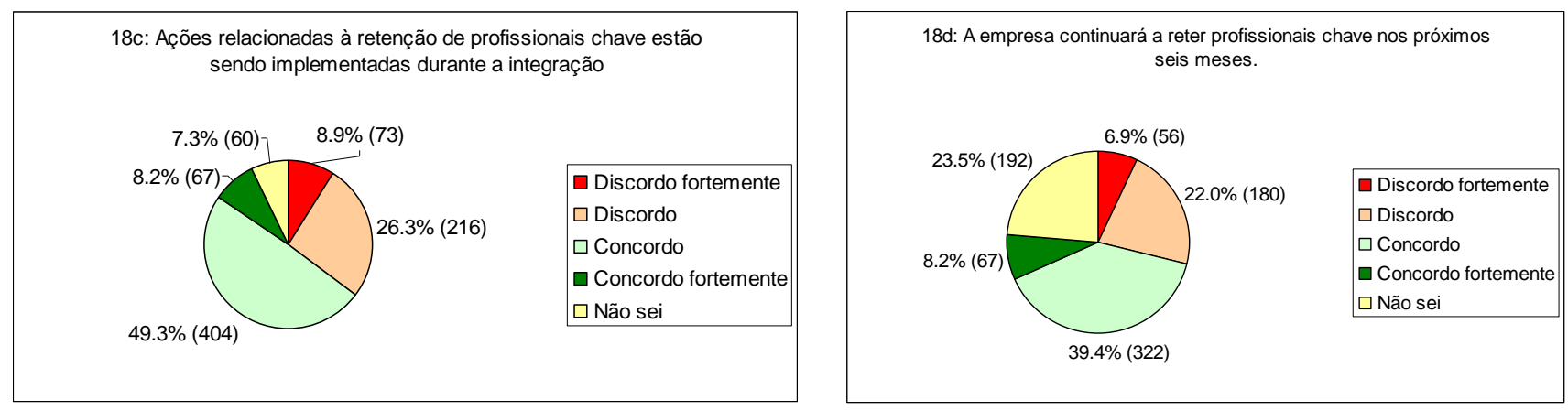

A combinação dos elementos positivos da visão de futuro com os problemas de comunicação, processo de integração e gestão de recursos humanos criam um interessante cenário nas variáveis relacionadas à clareza de expectativas.

Duas variáveis desta categoria apresentam níveis de concordância bastante positivos. Uma delas corresponde à clareza de expectativas em relação à atuação dos profissionais para a implementação da estratégia e a segunda representa o sentimento do grupo como pertencente a um time vencedor. O gráficos abaixo demonstram estes níveis de concordância dos profissionais, ambos superiores a $80 \%$ do total da amostra pesquisada.
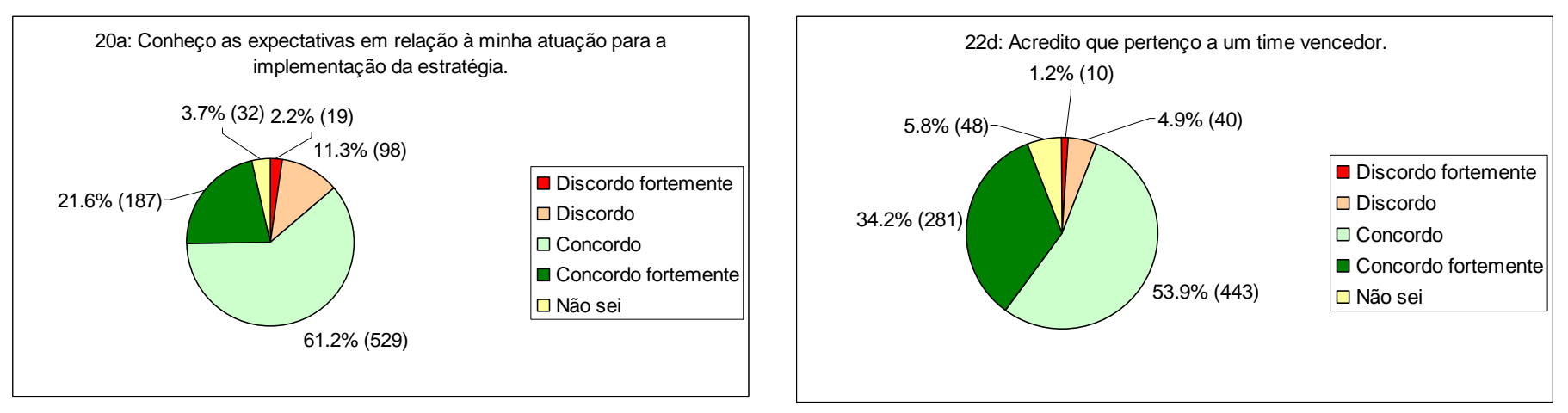

Por outro lado, as deficiências apontadas na gestão da integração prejudicam o entendimento de questões básicas deste tipo de processo de mudança organizacional, no qual as pessoas passam a desempenhar diferentes atribuições, bem como ter responsabilidade sobre novos objetivos e metas.

No caso das aquisições analisadas neste trabalho, os gráficos a seguir demonstram baixo nível de conhecimento dos profissionais em relação às metas financeiras da sua função. Além disso, a compreensão das metas de integração para a sinergia de custos, fundamental nos 
processos de combinação empresarial, apresenta-se desconhecida por quase $30 \%$ dos respondentes.
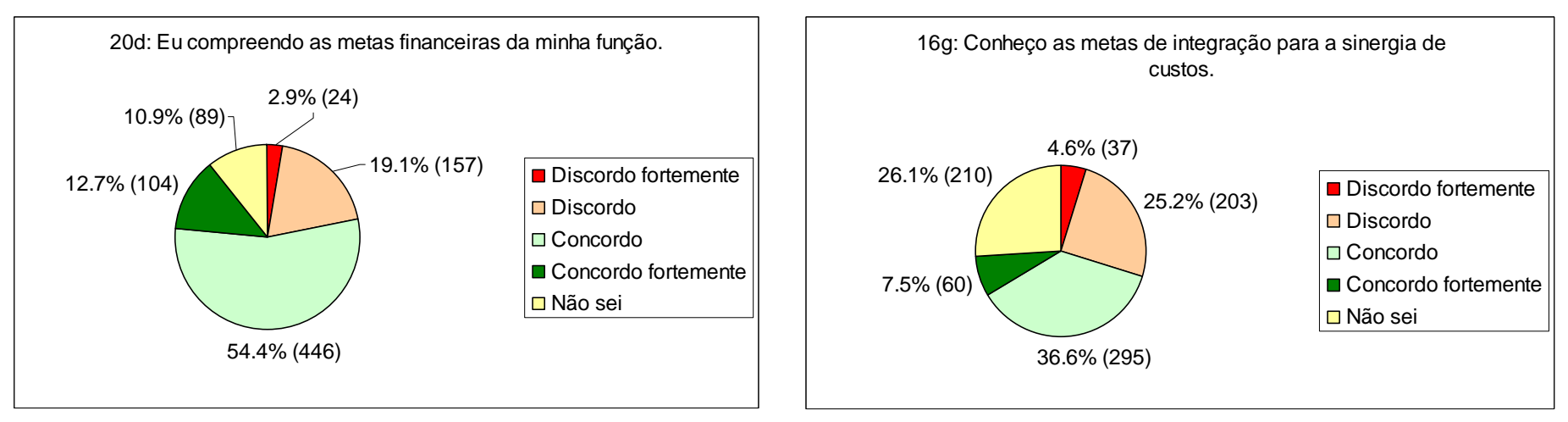

Dificuldades também estão presentes na compreensão do novo modelo organizacional adotado pela empresa Alfa. O gráfico a seguir demonstra que quase 25\% dos respondentes não conhecem as responsabilidades das pesoas no novo modelo organizacional estabelecido. Um dos comentários selecionados ilustra claramente esta situação: “não está claro para mim qual é a atual estrutura organizacional...há tantos organogramas disponibilizados no sistema”

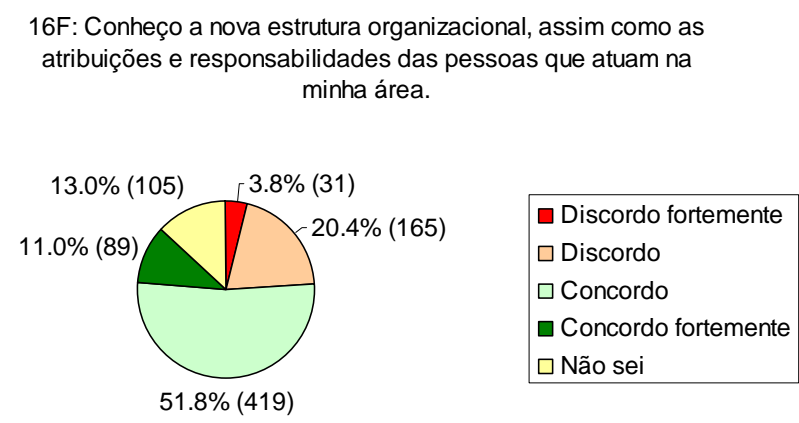

É interessante observar o impacto disto no relacionamento dos profissionais com seus respectivos gestores. De acordo com o gráfico abaixo, quase $28 \%$ das pessoas da amostra pesquisada afirmam que os seus gerentes não têm sido claros na comunicação do que será mudado na empresa e em seu conjunto de atribuições em decorrência da operação de combinação entre as empresas. Além disso, aproximadamente $20 \%$ dos profissionais questionam a capacidade de comunicação das mudanças por parte dos gestores, prejudicando 
a compreensão do processo de integração e das mudanças com possíveis impactos na sua área de atuação.

20e. Meu gestor tem sido claro quanto às mudanças decorrentes da integração e as suas causas.

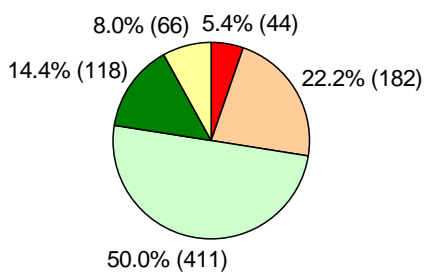

$\square$ Discordo

$\square$ Concordo

$\square$ Concordo fortemente

$\square$ Não sei

Os resultados destas questões afetam negativamente a qualidade da relação estabelecida entre os profissionais e a empresa, dificultando o entendimento e a adesão destes ao novo modelo organizacional. De acordo com mais de $20 \%$ dos respondentes, as pessoas não têm o nível de energia necessário para tornar a integração um sucesso.

18h: Os empregados têm neste momento energia suficiente para tornar a integração um sucesso.

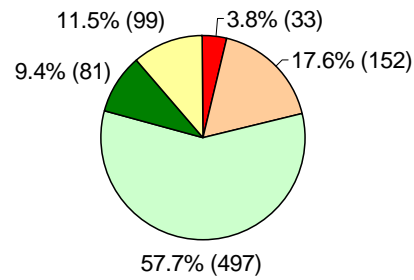

A aplicação do modelo de gestão da mudança formulado neste trabalho nas transações analisadas no estudo de caso da empresa Alfa leva à construção da seguinte tabela. Ela sintetiza a situação desta organização ao longo das etapas realizadas para viabilizar a compra das empresas Beta e Gama, bem como promove um detalhamento específico da etapa de integração pós-combinação, com base nas categorias elaboradas. 
Tabela 12: Aplicação do modelo de gestão da mudança no estudo de caso da empresa Alfa

\begin{tabular}{|c|c|c|}
\hline $\begin{array}{l}\text { Etapas da } \\
\text { combinação }\end{array}$ & Pontos positivos & Dificuldades encontradas \\
\hline $\begin{array}{l}\text { Planejamento } \\
\text { estratégico }\end{array}$ & $\begin{array}{l}\text { - Racional de aquisições para a estratégia de } \\
\text { crescimento da empresa claro e disseminado para } \\
\text { os profissionais da empresa Alfa }\end{array}$ & $\begin{array}{l}\text { - Baixa estruturação das atividades de planejamento estratégico nas } \\
\text { áreas, dificultando a elaboração de análises consistentes para a } \\
\text { identificação de oportunidades de aquisições nas diversas unidades } \\
\text { de negócios }\end{array}$ \\
\hline $\begin{array}{l}\text { Prospecção de } \\
\text { oportunidades }\end{array}$ & $\begin{array}{l}\text { - Verificação do alto nível de expertise disponível } \\
\text { na empresa, com base no perfil dos profissionais } \\
\text { alocados na nova área responsável por aquisições } \\
\text { e fusões }\end{array}$ & $\begin{array}{l}\text { - Excessiva aversão ao risco, verificada diante dos obstáculos } \\
\text { adicionais colocados pelo Comitê Diretivo da empresa para } \\
\text { considerar uma oportunidade atraente e viável }\end{array}$ \\
\hline $\begin{array}{l}\text { Avaliação de } \\
\text { oportunidades }\end{array}$ & $\begin{array}{l}\text { - Alto nível de comprometimento dos especialistas } \\
\text { alocados nos projetos de combinação } \\
\text { - Clareza da estrutura de grupos desenhada no } \\
\text { início do processo }\end{array}$ & $\begin{array}{l}\text { Excessiva carga de trabalho, morosidade do processo decisório e } \\
\text { baixa tolerância a erros criando descontentamento dos profissionais } \\
\text { envolvidos }\end{array}$ \\
\hline $\begin{array}{l}\text { Negociação e } \\
\text { efetivação do } \\
\text { acordo }\end{array}$ & $\begin{array}{l}\text { - Comprometimento dos integrantes do Core Team } \\
\text { em viabilizar a transação, apesar dos obstáculos } \\
\text { encontrados }\end{array}$ & $\begin{array}{l}\text { Baixa autonomia do Core Team para esta atividade e, portanto, } \\
\text { indefinições quanto ao processo decisório para a negociação, } \\
\text { enfraquecendo a situação da Alfa diante das empresas-alvo } \\
\text { - Problemas de relacionamento entre os Core Team e os consultores } \\
\text { externos diante da indefinição de responsabilidades }\end{array}$ \\
\hline $\begin{array}{l}\text { Integração pós- } \\
\text { combinação }\end{array}$ & $\begin{array}{l}\text { - Sentimento positivo de mobilização das pessoas } \\
\text { participantes do processo de integração } \\
\text { manifestado pelos profissionais dos Estados } \\
\text { Unidos }\end{array}$ & $\begin{array}{l}\text { - Modelo de governança para as decisões relacionadas à integração, } \\
\text { com baixa clareza do papel dos profissionais da matriz e dos Estados } \\
\text { Unidos } \\
\text { - Escassez de expertise instalada para a implementação efetiva dos } \\
\text { planos de integração elaborados } \\
\text { - Problemas pontuais na integração das áreas de informática e cadeia } \\
\text { de suprimentos }\end{array}$ \\
\hline
\end{tabular}


Tabela 13: Detalhamento da abordagem de gestão da mudança implementada na etapa de integração pós-combinação

\begin{tabular}{|c|c|c|}
\hline Categorias & Nível de desenvolvimento da abordagem de gestão da mudança & Diferenças de opinião entre os profissionais \\
\hline Visão de futuro & $\begin{array}{l}\text { - Alto nível de compreensão dos profissionais em relação à estratégia de } \\
\text { aquisições definida pela empresa } \\
\text { - Otimismo em relação ao futuro decorrente da boa capacidade de } \\
\text { implementação da estratégia, trazendo benefícios para a competitividade } \\
\text { da empresa na indústria } \\
\text { - } \quad \text { Preocupações dos profissionais com a diferenciação no mercado das três } \\
\text { marcas adquiridas, assim como da estruturação da cadeia de suprimentos }\end{array}$ & $\begin{array}{l}\text { - Opinião mais favorável dos profissionais da } \\
\text { empresa Gama, que demonstraram mais } \\
\text { elevados níveis de concordância em relação } \\
\text { às variáveis desta categoria }\end{array}$ \\
\hline Comunicação & $\begin{array}{l}\text { - Discordância dos respondentes em relação ao timing em que as as } \\
\text { informações foram disseminadas para as pessoas } \\
\text { - Desconforto das pessoas em relação à quantidade de informações } \\
\text { disponibilizadas ao longo do processo de mudança }\end{array}$ & $\begin{array}{l}\text { - Não há diferença estatisticamente } \\
\text { significante entre as opiniões dos } \\
\text { profissionais provenientes das empresas Alfa, } \\
\text { Beta e Gama em relação à comunicação }\end{array}$ \\
\hline $\begin{array}{l}\text { Processo de } \\
\text { integração }\end{array}$ & $\begin{array}{l}\text { - Morosidade na integração entre as políticas, práticas e instrumentos das } \\
\text { empresas Alfa, Beta e Gama } \\
\text { - Discordância em relação ao momento em que as decisões relacionadas à } \\
\text { integração foram tomadas }\end{array}$ & $\begin{array}{l}\text { - Não há diferença estatisticamente } \\
\text { significante entre as opiniões dos } \\
\text { profissionais provenientes das empresas Alfa, } \\
\text { Beta e Gama em relação ao processo de } \\
\text { integração }\end{array}$ \\
\hline $\begin{array}{l}\text { Gestão de } \\
\text { recursos } \\
\text { humanos }\end{array}$ & $\begin{array}{l}\text { - Dificuldade dos profissionais para a resolução de suas dúvidas referentes } \\
\text { à remuneração } \\
\text { - Baixa concordância com as ações de retenção de profissionais } \\
\text { implementadas pela empresa Alfa ao longo da integração }\end{array}$ & $\begin{array}{l}\text { - Problemas específicos na empresa Beta, } \\
\text { principalmente relacionados às restritas } \\
\text { oportunidades de carreira e gestão da } \\
\text { remuneração na nova organização } \\
\end{array}$ \\
\hline $\begin{array}{l}\text { Clareza de } \\
\text { expectativas }\end{array}$ & 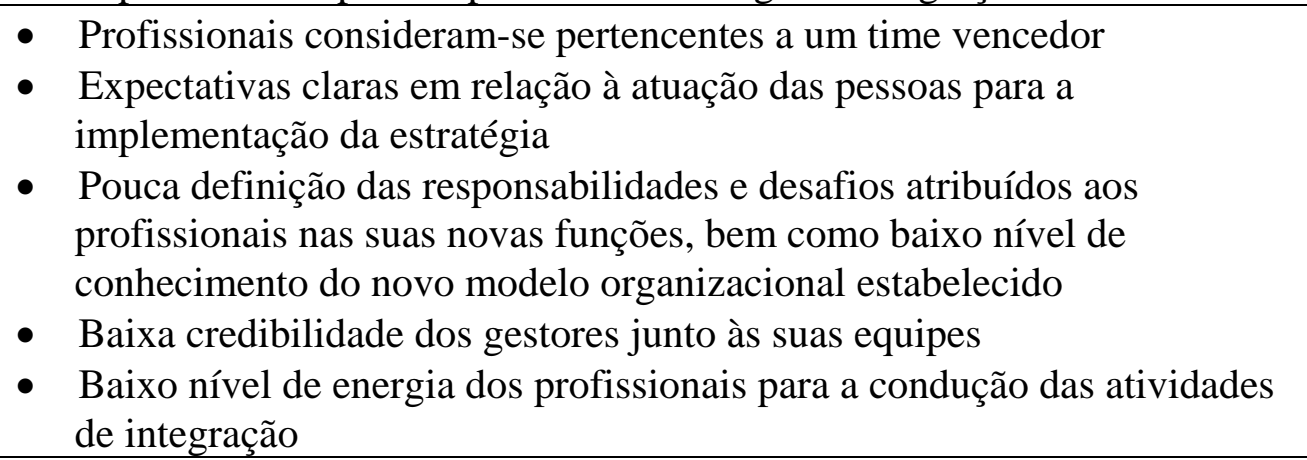 & $\begin{array}{l}\text { - Não há diferença estatisticamente } \\
\text { significante entre as opiniões dos } \\
\text { profissionais provenientes das empresas em } \\
\text { relação à clareza de expectativas } \\
\text { - Verifica-se, entretanto, a menor média de } \\
\text { concordância nos profissionais provenientes } \\
\text { da empresa Beta }\end{array}$ \\
\hline
\end{tabular}




\section{PARTE IV: CONSIDERAÇÕES FINAIS}

As combinações empresariais, caracterizadas por aquisições e fusões, são cada vez mais freqüentes na agenda de decisões dos líderes empresariais, com o objetivo de viabilizar estratégias de crescimento das organizações e levá-las a obter vantagens competitivas no mercado. Este trabalho procurou contribuir com o aperfeiçoamento da gestão destas transações, propondo um modelo que se baseia nos conhecimentos acumulados sobre mudanças de larga escala em organizações complexas.

A primeira constatação do estudo realizado diz respeito ao relevante crescimento da produção bibliográfica sobre o tema, indicando o aumento do interesse dos pesquisadores e, portanto, do conhecimento disponível sobre a gestão desses processos de combinações empresariais. Para assegurar o caráter acadêmico deste trabalho, foram coletadas publicações científicas produzidas em instituições de ensino e pesquisa tais como Harvard (Bower, 2001) e Insead (Haspeslagh \& Jemison, 1991), que criaram centros de estudos especializados neste assunto, respectivamente nos Estados Unidos e na França. Foram também pesquisadas referências ao tema em obras clássicas da bibliografia de administração de empresas, para identificar a origem da produção científica sobre as combinações empresariais. Verificou-se que, em meados dos anos sessenta e a partir da década de setenta do século $\mathrm{XX}$, os estudos sobre fusões e aquisições centravam-se na estratégia empresarial, buscando identificar as razões que motivavam a realização destas operações e o surgimento, a partir delas, de novas configurações organizacionais (Chandler, 1962; Miles \& Snow, 1978).

O aumento da relevância destas transações, assim como o crescimento significativo da sua frequência nos diversos setores econômicos, criou muitas oportunidades de trabalho e de especialização para as empresas internacionais de consultoria em gestão organizacional. Elas estruturaram novas unidades de negócios, especificamente voltadas para o suporte e o gerenciamento de aquisições e fusões nos diversos setores econômicos. A divulgação dos projetos desenvolvidos por estas consultorias tem incrementado as publicações sobre o assunto, relatando experiências e procurando estruturar metodologias próprias de intervenção e apoio à mudança. Exemplos típicos destas publicações foram desenvolvidos pelas empresas Pricewaterhouse Coopers, A.T.Kearney e McKinsey, respectivamente em Feldman \& Spratt 
(1999); Habeck, Kröger \& Träm (2000) e Kay \& Shelton (2000) e foram consultadas para enriquecer este trabalho com uma visão de diversas realidades.

Foi interessante consultar também publicações resultantes de parcerias entre universidades e empresas de consultoria como, por exemplo, a Boston Consulting Group e a Columbia University (Sirower, 1999), ou mesmo de empresas focadas na geração e disseminação de conhecimento sobre gestão organizacional tais como o Center for Creative Leadership e a National Association of Corporate Directors (Lajoux, 2006). Trata-se de um tipo de produção que procura associar o rigor acadêmico ao pragmatismo necessário às situações reais.

O conjunto dessa literatura torna evidente a necessidade de sistematizar a gestão do processo de mudança organizacional advindo dessas combinações empresariais. A estruturação desse modelo pode basear-se em fundamentos teórico-conceituais antecedendo a situação empírica. Pode também ser resultante de uma análise “pós-facto” de um ou mais casos de combinações, cujos processos de gestão foram mais ou menos satisfatórios. Ou ainda, ele pode ter sido construído durante a concepção e implementação das mudanças que concretizam a nova configuração organizacional.

O modelo de gestão da mudança para as combinações empresarias proposto neste trabalho fundamenta-se nas diversas fontes bibliográficas consultadas, agregando reflexões essencialmente teóricas com abordagens de caráter mais pragmático para as organizações.

Procurou-se manter o rigor acadêmico na construção do referencial teórico, assim como na abordagem metodológica e na postura do pesquisador. Com base nos trabalhos de Pettigrew (1985), adotou-se o processo de levantamento e análise dos dados que obedece um modelo de dois eixos - horizontal e vertical - o qual propicia a visão das etapas cronológicas e da profundidade do fenômeno de mudança organizacional estudado. Esta abordagem preliminar fortaleceu a relação do pesquisador com a organização objeto da pesquisa ao sinalizar a possibilidade de propiciar à empresa Alfa os resultados das análises, agregando valor ao seu processo concreto de transformação organizacional.

Essa contribuição da pesquisa para a organização objeto do estudo fundamenta-se nos pressupostos da pesquisa-ação (Thiollent, 1980). É importante destacar, entretanto, que esta 
proximidade do pesquisador à organização propicia benefícios ao trabalho mas, ao mesmo tempo, cria o risco de viéses que podem prejudicar a consistência das análises realizadas. A identificação destes riscos balizou as diversas decisões presentes no referencial metodológico, ou seja, a escolha das transações a serem estudadas, a seleção de gestores a serem entrevistados e a composição da amostra de profissionais para a aplicação do questionário, buscando-se manter a objetividade e preservar a independência do pesquisador e relação ao objeto de pesquisa.

De acordo com o referencial teórico elaborado, foi possível construir uma sequência de etapas necessárias para a conclusão de uma combinação empresarial, utilizando-se como base as reflexões presentes nas publicações de Marks \& Mirvis (1998), Sirower (1999) e Galpin \& Herndon (2000). Foram identificadas etapas com escopo e procedimentos claramente definidos, iniciando-se com a concepção da idéia de combinação no processo de planejamento estratégico das empresas e terminando com a integração pós-combinação, quando as empresas agregam os seus recursos e esforços para a viabilização do modelo de negócios concebido.

A análise destas etapas levou à verificação de uma clara divisão entre dois momentos das combinações. O primeiro deles correspondente ao processo decisório que baliza a operação. São identificadas inicialmente as oportunidades de aquisições e fusões correspondentes às intenções de crescimento das empresas, assim como são realizadas todas as análises de viabilidade e riscos que envolvem a operação. O fechamento do acordo, concretizando a transação, inicia o segundo momento característico destes processos, no qual se configuram os desafios correspondentes à integração entre as organizações participantes da combinação.

A natureza específica destes dois distintos momentos leva alguns dos trabalhos consultados a focarem as suas reflexões predominantemente em um deles. A natureza estratégica da operação e os parâmetros financeiros que são empregados para tomar a decisão são discutidos com maior profundidade respectivamente por Bower (2001) e Sirower (1999). Os autores Marks \& Mirvis (1998) e Lajoux (2006), por sua vez, deslocam o seu foco de atenção e concentram as suas análises nos desafios da integração. De maneira complementar, Haspeslagh \& Jemison (1991) reforçam a existência de problemáticas específicas em cada um dos dois momentos, salientando a divisão mencionada. 
Com esse referencial foi possível verificar, no caso estudado, a possibilidade de duas contribuições ao aperfeiçoamento da gestão da transação. A primeira corresponde à identificação da categoria clareza de expectativas para a etapa de integração pós-combinação. A proposição desta nova categoria foi possível diante do mix metodológico adotado, composto por técnicas qualitativas e quantitativas. As variáveis alocadas a esta categoria, provenientes da análise fatorial, trazem elementos para o estabelecimento da relação entre os profissionais e a empresa. São trabalhadas dimensões de curto e longo prazo, ampliando o entendimento das pessoas sobre as suas responsabilidades na nova estrutura e também sobre a sua contribuição para o sucesso do negócio. Esta categoria destaca a importância do papel dos gestores no que se refere à comunicação das mudanças e à tradução da visão de futuro da empresa, para que os integrantes das suas equipes adquiram plena compreensão do processo de mudança e do papel que desempenham nele.

A clareza de expectativas apresenta-se como uma importante dimensão na estruturação de abordagens de mudança para as aquisições e fusões. Ela reforça a adesão e o comprometimento dos profissionais com as proposições de mudanças que as empresas necessitam em virtude dos processos de combinação. Seu conteúdo deve, portanto, complementar o detalhamento da etapa de integração pós-combinação do modelo de gestão adotado neste tipo de transação.

O refinamento da etapa de integração e a verificação da sua importância para o sucesso das aquisições e fusões fornecem insumos para uma segunda contribuição advinda deste trabalho. Verificou-se que a dissociação entre o processo decisório das transações e a elaboração de estratégias de integração, característica das abordagens de gestão de mudança normalmente implementadas, pode prejudicar a efetividade destas operações.

O referencial teórico que norteou a pesquisa empírica demonstrou a importância de não dissociar a etapa de integração do processo decisório de combinações empresariais. A relevância de um planejamento estruturado, para a posterior viabilização da integração efetiva entre as empresas, demonstra que as atividades do segundo momento característico destas operações devem ser iniciadas com antecedência. Esta constatação ressalta a necessidade de conceber a estratégia de integração concomitantemente ao processo decisório da operação. Significa dizer que as variáveis que neste trabalho foram apresentadas como características da 
etapa de integração pós-combinação devem ser antecipadas no gerenciamento da transação e incorporadas às etapas iniciais, nas quais são realizadas a due-diligence e a análise de viabilidade da operação.

O refinamento das categorias da etapa de integração, com a inclusão da clareza de expectativas, e a antecipação da reflexão sobre a integração das empresas para o início do processo aprimoram o processo de gestão das operações de combinação. A adoção deste tipo de modelo de gestão da mudança pode se tornar uma importante fonte de vantagens competitivas em relação aos concorrentes para as empresas cujas estratégias de crescimento baseiam-se primordialmente em aquisições e fusões.

As constatações deste trabalho podem contribuir também para a ampliação e o aprofundamento da pesquisa sobre o tema de combinações empresariais, incorporando às análises e reflexões os conceitos de aprendizagem organizacional, de desenvolvimento de competências e as proposições de modelos de atuação em equipes oriundos da literatura sobre processos de mudança de larga escada.

Para fortalecer a capacidade de adaptação das empresas às mudanças instauradas pelo processo de combinação é recomendável estabelecer uma cultura de aprendizagem visando estimular a compreensão da diversidade das empresas que compõem a combinação. Esta diversidade emerge, inevitavelmente, na manifestação dos padrões culturais, assim como nos modelos organizacionais, nos processos de trabalho e nos instrumentos de gestão. Diante disto, torna-se possível adotar as melhores práticas, potencializando o aproveitamento dos elementos positivos de cada uma das organizações. Dessa forma, as decisões de combinação empresarial que estão fundamentadas quase exclusivamente em variáveis financeiras e, portanto, não levam em consideração os demais elementos característicos da diversidade encontradas nas organizações, correm o risco de tornarem-se inconsistentes. Isso ressalta a importância de incluir outras áreas de expertise da organização desde o planejamento da combinação empresarial e não apenas depois que a operação é realizada, quando já são restritas as oportunidades e condições para que os gestores do processo de mudança assegurem a efetividade da operação. 
A freqüência de casos de insucesso na implantação de etapas de integração em aquisições e fusões mostra também a necessidade das empresas desenvolverem em seus profissionais as competências requeridas para o exercício da gestão de mudanças. Estes executivos devem ter ampla compreensão de estratégia e negócios mas, ao mesmo tempo, percepção desenvolvida para apreender a diversidade organizacional e para criar condições de estimulo à aprendizagem entre as pessoas oriundas das empresas a serem integradas. A aplicação plena destas competências demanda a adoção de modelos de atuação em equipes de modo a reduzir conflitos interpessoais e estimular o alinhamento dos profissionais às diretrizes estratégicas da nova organização.

Por fim, é importante ressaltar que este trabalho foi elaborado para contribuir com o desenvolvimento de empresas cujas atividades relacionam-se ao chamado setor de ciências da vida A dificuldade de delimitação das fronteiras deste setor, abrangendo elementos de química, farmácia, biotecnologia e bens de consumo, cria oportunidades para a expansão dos negócios dessas organizações através de aquisições e fusões. Diante dos baixos indicadores de sucesso verificados nas combinações empresariais em geral, futuras pesquisas podem aplicar o modelo de gestão da mudança elaborado em outros setores de produção econômica, avançando as reflexões iniciadas neste trabalho. Novas aplicações empíricas podem identificar outras oportunidades de refinamento e sofisticação deste modelo, assim como promover o desenvolvimento de outros tipos de empresas que estejam enfrentando os desafios característicos de processos desta natureza. 


\section{APÊNDICE A: LINHA DO TEMPO DAS EMPRESAS QUÍMICAS QUE PASSARAM A ATUAR EM CIÊNCIAS DA VIDA}

Para a compreensão da evolução das empresas químicas que passaram a atuar no setor de ciências da vida, são apresentadas na seqüência linhas do tempo, com fatos relevantes ocorridos ao longo da sua história.

Para a descrição destes fatos, as datas ao longo dos séculos XX e XI foram divididas em décadas visando facilitar a análise comparativa entre as empresas. Os eventos ocorridos nos séculos anteriores foram descritos conforme o ano em que ocorreram.

Foram escolhidos os seguintes fatos para compor os eventos relevantes das empresas selecionadas:

- Início das operações de cada uma das empresas;

- Lançamento de produtos relevantes;

- Abertura e fechamento de fábricas;

- Operações de combinação, compostas por aquisições, fusões e cisões.

\begin{tabular}{|c|c|}
\hline \multicolumn{2}{|l|}{ Geigy } \\
\hline 1758 & $\begin{array}{l}\text { - Johann Rudolf Geigy-Gemuseus (1733-1793) começa a comercializar } \\
\text { produtos químicos, tinturas (corantes) e medicamentos na cidade de } \\
\text { Basiléia, Suíça. }\end{array}$ \\
\hline 1857 & $\begin{array}{l}\text { - Johann Rudolf Geigy Merian (1830-1917), juntamente com Johann Müller- } \\
\text { Pack, adquire uma sede na Basiléia onde constrói uma usina para processar } \\
\text { madeiras de tinturaria e uma fábrica de extração de tintas. Apenas dois anos } \\
\text { mais tarde, começam as produções de Fucsinas sintéticas. }\end{array}$ \\
\hline 1898 & - $\quad$ Fundação da fábrica em Grenzach, Alemanha. \\
\hline $\begin{array}{l}\text { De } 1900 \text { a } \\
1909\end{array}$ & - Mudança para uma empresa limitada de capital aberto. \\
\hline $\begin{array}{l}\text { De } 1910 \quad \text { a } \\
1919\end{array}$ & - $\quad$ Em 1914 ocorre a mudança do nome da companhia para J. R. Geigy Ltd. \\
\hline
\end{tabular}




\begin{tabular}{|c|c|}
\hline $\begin{array}{lll}\text { De } 1920 \quad \text { a } \\
1929\end{array}$ & $\begin{array}{l}\text { - Fundação da Geigy Colour Company Ltd., em Manchester. Três anos mais } \\
\text { tarde é inaugurada uma fábrica em Huningue, França, para a produção de } \\
\text { acessórios têxteis. }\end{array}$ \\
\hline $\begin{array}{lll}\text { De } 1930 \quad \text { a } \\
1939\end{array}$ & $\begin{array}{l}\text { - Inicia-se a produção de inseticidas estabelecendo-se a atividade de } \\
\text { defensivos agrícolas em } 1935 \text {. } \\
\text { - Criação do departamento farmacêutico e início da produção na nova fábrica } \\
\text { de Schweizerhalle. }\end{array}$ \\
\hline \begin{tabular}{|lll} 
De & $1940 \quad$ a \\
1949 & &
\end{tabular} & $\begin{array}{l}\text { - Paul Muller, um pesquisador da Geigy, descobre a eficácia do DDT como } \\
\text { inseticida e recebe o prêmio Nobel de } 1948 \text { em reconhecimento ao seu } \\
\text { trabalho. } \\
\text { - O medicamento anti-reumático Butazolidin é o primeiro medicamento } \\
\text { importante da Empresa. }\end{array}$ \\
\hline $\begin{array}{l}\text { De } 1950 \\
1959\end{array}$ & $\begin{array}{l}\text { - Lançamento dos primeiros herbicidas com base na triazina (Simazine, } \\
\text { Atrazine). } \\
\text { - Lançamento do Tofranil, que obtém seus primeiros sucessos na área de } \\
\text { medicamentos psicotrópicos. } \\
\text { - Lançamento do medicamento Hygrotone, o primeiro diurético de longa } \\
\text { duração para o tratamento da hipertensão. }\end{array}$ \\
\hline $\begin{array}{lll}\text { De } 1960 \quad \text { a } \\
1969\end{array}$ & - Lançamento do Tregretol, um medicamento para o tratamento da epilepsia. \\
\hline
\end{tabular}

\begin{tabular}{|c|c|}
\hline \multicolumn{2}{|l|}{ Ciba } \\
\hline 1859 & $\begin{array}{l}\text { - Alexander Clavel (1805-1873) inicia a produção de Fucsina em sua fábrica } \\
\text { de tingimento, na cidade de Basiléia, Suiça. }\end{array}$ \\
\hline 1864 & $\begin{array}{l}\text { - Em } 1864 \text { é construída uma nova unidade para a produção de corantes } \\
\text { sintéticos }\end{array}$ \\
\hline 1873. & $\begin{array}{l}\text { - Clavel vende sua fábrica de corantes para a companhia Bindschedler \& } \\
\text { Busch. }\end{array}$ \\
\hline 1876 & $\begin{array}{l}\text { - São estabelecidas representações comerciais para a Bindschedler \& Busch } \\
\text { na Alemanha, França, Inglaterra, Itália, Rússia e EUA. }\end{array}$ \\
\hline 1884 & $\begin{array}{l}\text { - A Bindschedler \& Busch foi transformada em uma sociedade por ações } \\
\text { com o nome de Gesellschaft für Chemische Industrie Basel ou Cia. Basel }\end{array}$ \\
\hline
\end{tabular}




\begin{tabular}{|c|c|}
\hline & da Indústria Química. \\
\hline $\begin{array}{ll}\text { De } 1900 \text { a } \\
1909\end{array}$ & $\begin{array}{l}\text { - Produção das primeiras substâncias farmacêuticas, o Vioform } \\
\text { (medicamento anti-séptico) e o Salen (agente anti-reumático). } \\
\text { - Aquisição de uma unidade de produção em Monthey, Suíça em } 1908\end{array}$ \\
\hline $\begin{array}{ll}\text { De } 1910 \text { a } \\
1919\end{array}$ & $\begin{array}{l}\text { - Criação da Interessengemeinschaft Basel ou Basler IG, um consórcio entre } \\
\text { a Sandoz, a Ciba e a Geigy. } \\
\text { - Em 1911, são inauguradas fábricas na Inglaterra (Clayton) e na Itália } \\
\text { (Milão) e, em 1915, na Rússia (Moscou) e Alemanha (Berlim). }\end{array}$ \\
\hline $\begin{array}{l}\text { De } 1920 \text { a } \\
1929\end{array}$ & $\begin{array}{l}\text { - A Coramina, medicamento para o tratamento da circulação, é sintetizada. } \\
\text { - Incorporação da produção de acessórios têxteis da Geigy. }\end{array}$ \\
\hline $\begin{array}{l}\text { De } 1940 \text { a } \\
1949\end{array}$ & $\begin{array}{l}\text { - A resina epóxi Araldite é lançada no mercado de adesivos. A abreviação } \\
\text { Ciba se torna tão popular que é adotada como nome da companhia em } \\
1945 \text {. }\end{array}$ \\
\hline $\begin{array}{l}\text { De } 1950 \text { a } \\
1959\end{array}$ & $\begin{array}{l}\text { - } \quad \text { Em 1950, a Basler IG é dissolvida. } \\
\text { - } \quad \text { Iniciada a produção de inseticidas em } 1954 .\end{array}$ \\
\hline 1960 a 1969 & $\begin{array}{l}\text { - Lançamento do Desferal, um produto inovador para o tratamento do } \\
\text { excesso de alumínio e ferro decorrente da talassemia, uma enfermidade do } \\
\text { sangue. }\end{array}$ \\
\hline $\begin{array}{l}\text { De } 1970 \text { a } \\
1979\end{array}$ & - Fusão da Ciba e da Geigy, formando a Ciba-Geigy Ltd. \\
\hline $\begin{array}{ll}\text { De } 1980 \text { a } \\
1989\end{array}$ & - A empresa lança em 1980 uma unidade especial de biotecnologia. \\
\hline $\begin{array}{ll}\text { De } 1990 \text { a } \\
1999\end{array}$ & $\begin{array}{l}\text { - Em 1992, a companhia adota o nome de Ciba e um novo logotipo, de } \\
\text { caráter mais moderno reforçando a inovação tecnológica. }\end{array}$ \\
\hline
\end{tabular}

\begin{tabular}{|l|l|}
\hline \multicolumn{2}{|l|}{ Sandoz } \\
\hline 1886 & $\begin{array}{l}\text { Estabelecimento da empresa química Kern \& Sandoz, na Basiléia, pelos } \\
\text { Drs. Alfred Kern (1850-1893) e Edouard Sandoz (1853-1928). Os } \\
\text { primeiros corantes produzidos são o azul de alizarina e a auramina. }\end{array}$ \\
\hline 1895 & $\begin{array}{l}\text { Produção da primeira substância farmacêutica, antipirina, um agente } \\
\text { controlador da febre. A sociedade limitada torna-se uma sociedade por } \\
\text { ações, a "Chemische Fabrik Vormals Sandoz". }\end{array}$ \\
\hline
\end{tabular}




\begin{tabular}{|c|c|}
\hline 1899 & $\begin{array}{l}\text { - Ocorre a primeira diversificação para o ramo de adoçantes e inicia-se a } \\
\text { produção de sacarina }\end{array}$ \\
\hline $\begin{array}{l}\text { De } 1910 \text { a } \\
1919\end{array}$ & $\begin{array}{l}\text { - Criação do Departamento Farmacêutico pelo Prof. Arthur Stoll (1887- } \\
\text { 1971) e início da pesquisa farmacêutica. } \\
\text { - Arthur Stoll isola a Ergotamina a partir do ergot, um fungo do milho, que } \\
\text { em 1921, é lançado sob o nome comercial de Gynergen. }\end{array}$ \\
\hline $\begin{array}{ll}\text { De } 1920 \quad \text { a } \\
1929\end{array}$ & $\begin{array}{l}\text { - Lançamento do Calcium Sandoz, um produto inovador que se torna o } \\
\text { alicerce da terapia de cálcio moderna. } \\
\text { - É organizado o Departamento Químico da empresa, composto por químicos } \\
\text { para produtos têxteis, de couro e papel. }\end{array}$ \\
\hline $\begin{array}{ll}\text { De } 1930 \text { a } \\
1939\end{array}$ & $\begin{array}{l}\text { - Ocorrem as primeiras iniciativas no ramo de defensivos agrícolas, com } \\
\text { pesquisas sobre o cobre. }\end{array}$ \\
\hline $\begin{array}{ll}\text { De } 1940 \text { a } \\
1949\end{array}$ & - $\quad$ Lançado o pesticida Copper Sandoz em 1943. \\
\hline $\begin{array}{ll}\text { De } 1950 \text { a } \\
1959\end{array}$ & $\begin{array}{l}\text { - Lançado o medicamento neuroléptico Melleril promovendo o } \\
\text { desenvolvimento da farmacologia psicotrópica. }\end{array}$ \\
\hline $\begin{array}{lll}\text { De } 1960 \text { a } \\
1969\end{array}$ & $\begin{array}{l}\text { - } \quad \text { Aquisição da Biochemie GmbH em Kundl, na Áustria. } \\
\text { - Produção em grande escala de antibióticos e substâncias desenvolvidas sob } \\
\text { - Inauguração do priotecnológica. } \\
\text { Hanover (New Jersey, Estados Unidos). } \\
\text { - Fusão com a Wander Ltd. e diversificação do ramo dietético (Ovaltine, } \\
\text { Isostar). }\end{array}$ \\
\hline $\begin{array}{ll}\text { De } 1970 \text { a } \\
1979\end{array}$ & $\begin{array}{l}\text { - Inauguração Instituto de Pesquisas Sandoz, em Viena, Áustria. } \\
\text { - Aquisição da Delmark, em } 1972 .\end{array}$ \\
\hline $\begin{array}{ll}\text { De } 1980 \text { a } \\
1989\end{array}$ & $\begin{array}{l}\text { - } \quad \text { Aquisição da Wasa (fabricante sueco de pães crocantes), em } 1982 \\
\text { - } \quad \text { Inauguração do Instituto Sandoz de Pesquisa Médica, em Londres. }\end{array}$ \\
\hline $\begin{array}{ll}\text { De } 1990 \quad \text { a } \\
1999\end{array}$ & - $\quad$ Aquisição da Gerber Babyfood, em 1994. \\
\hline
\end{tabular}

\section{Novartis}

De 1990 a

- Novartis é criada a partir da fusão das empresas Ciba-Geigy e Sandoz em 


\begin{tabular}{|c|c|}
\hline 1999 & $\begin{array}{l}1995 \\
\text { - A empresa adquire a divisão de proteção de cultivos da Merck em 1997, } \\
\text { acrescentando o inseticida abamectin ao seu amplo portfólio de produtos } \\
\text { já existente. } \\
\text { - Em } 1998 \text { é anunciada a formação do Novartis Agricultural Discovery } \\
\text { Institute (NADI), um dos maiores centros de pesquisa dedicados à pesquisa } \\
\text { e desenvolvimento do genoma agrícola. }\end{array}$ \\
\hline $\begin{array}{l}\text { A partir de } \\
2000\end{array}$ & $\begin{array}{l}\text { - O mapeamento do genoma humano aumentou significativamente o número } \\
\text { de alvos potenciais para novos medicamentos, de aproximadamente } 500 \\
\text { para mais de } 10.000 \text {. } \\
\text { - A Novartis reorganizou suas prioridades em pesquisas para aumentar a } \\
\text { produtividade e o fluxo de novos compostos em desenvolvimento. Foram } \\
\text { concentrados esforços significativos para colocar novas substâncias em } \\
\text { estágios de desenvolvimento no processo de pesquisa, buscando-se } \\
\text { consolidar esta fonte de vantagens competitivas. }\end{array}$ \\
\hline
\end{tabular}

\begin{tabular}{|l|ll|}
\hline \multicolumn{1}{|l|}{ ICI } \\
\hline 1929 & $\begin{array}{l}\text { A Imperial Chemical Industries Ltd.- ICI - é fundada em } 1926 \text { a partir da } \\
\text { fusão das empresas químicas inglesas Brunner e Mond, com forte apoio do } \\
\text { governo local. } \\
\text { • }\end{array}$ & $\begin{array}{l}\text { Tem início em } 1928 \text { o funcionamento da Agricultural Research Station em } \\
\text { Jealott's Hill na Inglaterra. }\end{array}$ \\
\hline De 1930 a & $\begin{array}{l}\text { A ICI fez um acordo de licenças com a Shell e IG Farben para a construção } \\
\text { de unidades de produção de gasolina sintética a partir do carvão. }\end{array}$ \\
& $\begin{array}{l}\text { Nas unidades de gasolina sintética, a ICI desenvolveu um processo de } \\
\text { reforma catalítica de hidrocarbonetos leves para a produção de amônia e } \\
\text { metanol, destacando-se significativamente das empresas da época neste tipo } \\
\text { de tecnologia. } \\
\text { Foi lançada em 1932 a folha acrílica Perspex. } \\
\text { Em 1933, o polietileno foi descoberto por E.W. Fawcett e R.O. Gibson da } \\
\text { ICI, permanecendo até hoje como um dos plásticos bastante utilizado no } \\
\text { mundo. }\end{array}$ \\
\hline
\end{tabular}




\begin{tabular}{|c|c|}
\hline & $\begin{array}{l}\text { - ICI faz uma joint venture com a Cooper McDougall \& Robertson Limited } \\
\text { para formar a Plant Protection Limited (PPL) em } 1937 . \\
\text { - A ICI entra no campo farmacêutico nos fins dos anos 30, inovando em } \\
\text { sulfonamidas e drogas antimaláricas. }\end{array}$ \\
\hline $\begin{array}{l}\text { De } 1940 \text { a } \\
1949\end{array}$ & $\begin{array}{l}\text { - O Dr. Bill Templeman, de Jealott's Hill, descobre as propriedades seletivas } \\
\text { do ácido alfanaftlacético, que leva à síntese de dois herbicidas: MCPA e } \\
\text { 2,4. } \\
\text { - Lançado o grupo de pesquisas farmacêuticas criado pela ICI, denominado } \\
\text { Dyestuffs Research Laboratory. Foi desenvolvida neste período uma droga } \\
\text { antimalárica: a cloroguamida. } \\
\text { - No fim da Segunda Guerra Mundial, a ICI estabeleceu acordo de cessão de } \\
\text { licenças com a DuPont. A ICI poderia produzir nylon e a DuPont o } \\
\text { Polietileno. } \\
\text { A DuPont reconheceu a precedência inglesa na descoberta da fibra } \\
\text { poliéster e acabou negociando com a ICI os direitos da utilização da patente } \\
\text { inglesa. }\end{array}$ \\
\hline $\begin{array}{l}\text { De } 1950 \text { a } \\
1959\end{array}$ & $\begin{array}{l}\text { - Lançamento do corante Procion, uma escala de tinturas que são } \\
\text { quimicamente combinadas com o algodão para a obtenção de cores mais } \\
\text { intensas. } \\
\text { - Lançamento do Fluothane, uma revolucionária anestesia inaladora. } \\
\text { - São desfeitas as alianças com a DuPont, as quais impediam que a ICI } \\
\text { comercializasse os seus produtos no mercado americano e europeu } \\
\text { continental. } \\
\text { - Um grupo de produtos químicos originalmente descoberto em } 1947 \text { é } \\
\text { reavaliado, levando à descoberta e desenvolvimento de diquat e paraquat, } \\
\text { dois agentes ativos para defensivos agrícolas. }\end{array}$ \\
\hline $\begin{array}{l}\text { De } 1960 \text { a } \\
1969\end{array}$ & $\begin{array}{l}\text { - James Black, da ICI, descobriu o propanolol (Inderal), um importante } \\
\text { medicamento para o tratamento da hipertensão, distúrbios cardiovasculares, } \\
\text { angina pectoris e arritimias cardíacas. } \\
\text { - A PPL passa a fazer parte da Divisão Agrícola da ICI em } 1964 .\end{array}$ \\
\hline $\begin{array}{l}\text { De } 1970 \text { a } \\
1979\end{array}$ & $\begin{array}{l}\text { - } \text { Descoberta a fibra inorgânica Saffil. } \\
\text { - } \quad \text { A PPL torna-se totalmente independente da Divisão Agrícola. }\end{array}$ \\
\hline
\end{tabular}




\begin{tabular}{|c|c|}
\hline & $\begin{array}{l}\text { Foi alcançado significativo progresso nas pesquisas de drogas para o } \\
\text { tratamento de alguns tipos de câncer. Foi lançado em } 1977 \text { o Novaldex } \\
\text { (tamoxifeno). } \\
\text { - O fungicida sistêmico Ridomil é introduzido em } 1978 .\end{array}$ \\
\hline $\begin{array}{l}\text { De } 1980 \text { a } \\
1989\end{array}$ & $\begin{array}{l}\text { - É formada em } 1983 \text { a ICI Seeds para agregar capacidade de produção de } \\
\text { - } \quad \text { É lançado o inseticida piretróide Karate em } 1985 . \\
\text { - } \quad \text { A ICI adquire a Stauffer Chemical Company em } 1987 .\end{array}$ \\
\hline
\end{tabular}

\section{Zeneca}

\begin{tabular}{|l|ll}
\hline De 1990 a & A Zeneca, englobando o setor farmacêutico, defensivos agrícolas e
\end{tabular} 1999 sementes, separa-se da ICI em 1993.

- Ocorre uma fusão dos negócios de defensivos agrícolas e sementes formando uma nova empresa em 1995: a Advanta.

- O fungicida strubilurin Amistar é registrado em 1996.

- É adquirida em 1997 a empresa de biotecnologia Morgen, sediada na Holanda, com o objetivo de reforçar a capacidade do setor de biotecnologia.

- São adquiridos os direitos de utilização do agente ativo Clorotalonil, provenientes da empresa química ISK.

- A Astra e Zeneca se fundem em 1999, passando a atuar no setor farmacêutico.

\section{Syngenta}

\begin{tabular}{|l|l|}
\hline A partir de & $\begin{array}{l}\text { A Novartis agribusiness e a Zeneca agroquímicos se fundem em 2000, } \\
\text { formando a Syngenta, empresa focada no setor de defensivos agrícolas, } \\
\text { sementes e ciências da plata, com sede na cidade de Basel na Suiça. }\end{array}$ \\
$\begin{array}{l}\text { A Szngenta inicia as suas atividades em biopharma em 2002, utilizando o } \\
\text { seu conhecimento em ciências da planta para a produção de medicamentos. } \\
\text { A empresa inicia aquisições de empresas de sementes e biotecnologia } \\
\text { visando ampliar o seu portfolio de produtos e alavancar as suas atividades } \\
\text { de pesquisa e desenvolvimento neste setor. }\end{array}$ \\
\hline
\end{tabular}




\begin{tabular}{|l|l|}
\hline & $\begin{array}{l}\text { A Syngenta anuncia em } 2006 \text { uma joint venture com a DuPont, } \\
\text { denominada GreenLeaf e sediada nos Estados Unidos, para pesquisa e } \\
\text { comercialização conjunta de tecnologia de milho e soja transgênica. }\end{array}$ \\
\hline
\end{tabular}

\begin{tabular}{|c|c|}
\hline \multicolumn{2}{|l|}{ Hoechst } \\
\hline 1860 & $\begin{array}{l}\text { - Eugen Lucius inicia testes de laboratório para produzir tintas sintéticas em } \\
\text { Frankfurt. }\end{array}$ \\
\hline 1863 & - É fundada a Farbenfabrik Meister Lucius \& Co. Em Hoechst am Main. \\
\hline 1869 & $\begin{array}{l}\text { - Construção da fábrica de tintas, cujas instalações permanecem no mesmo } \\
\text { local até } 1999 .\end{array}$ \\
\hline 1880 & $\begin{array}{l}\text { - } \quad \text { Transformação da empresa em uma sociedade por ações denominada } \\
\text { Farbwerke vormals Meister Lucius \& Bruning, em Hoechst am Main. }\end{array}$ \\
\hline 1883 & - Início da produção farmacêutica pela empresa. \\
\hline $\begin{array}{l}\text { De } 1920 \text { a } \\
1949\end{array}$ & $\begin{array}{l}\text { - Juntamente com outras importantes empresas químicas da Alemanha, a } \\
\text { Farbwerke e Hoechst se convertem como parte da I.G. Farbenindustrie. }\end{array}$ \\
\hline $\begin{array}{l}\text { De } 1950 \text { a } \\
1959\end{array}$ & $\begin{array}{l}\text { - A empresa é reconstituída com o nome de Ferberwerke Hoechst AG vorm. } \\
\text { Meister Lucius \& Bruning. Nasce, neste momento, uma organização com } \\
\text { unidades de negócio em vários países do mundo. }\end{array}$ \\
\hline $\begin{array}{l}\text { De } 1960 \text { a } \\
1969\end{array}$ & - Tem início a cooperação com a Roussel Uclaf S.A. \\
\hline $\begin{array}{l}\text { De } 1970 \text { a } \\
1979\end{array}$ & $\begin{array}{l}\text { - A Farber Hoechst AG vorm. Meister Lucius \& Bruning é rebatizada como } \\
\text { Hoechst Aktiengesellschaft. }\end{array}$ \\
\hline $\begin{array}{l}\text { De } 1980 \text { a } \\
1989\end{array}$ & - $\quad$ Ocorre a aquisição da Celanese Corporation nos Estados Unidos. \\
\hline $\begin{array}{l}\text { De } 1990 \text { a } \\
1999\end{array}$ & $\begin{array}{l}\text { - Jurgen Dormann é nomeado Chief Executive Officer da Hoechst AG em } \\
\text { 1994. Começam, neste período, alianças e aquisições na área de ciências } \\
\text { biológicas. } \\
\text { - Aquisição da Marion Merrell Dow em 1995. Integração da Marion, } \\
\text { Roussel-Uclaf e Hoechst Pharma com a criação da Hoechst Marion } \\
\text { Roussel. } \\
\text { - Em } 1997 \text { a Hoechst AG transforma-se em uma Corporação com unidades }\end{array}$ \\
\hline
\end{tabular}




\begin{tabular}{|l|l|}
\hline & $\begin{array}{l}\text { de negócio independentes. } \\
\bullet\end{array}$ \\
Hoechst AG associa-se com Rhone-Poulenc para constituição da Aventis \\
em 1999, consolidando o foco desta empresa em ciências da vida.
\end{tabular}

\begin{tabular}{|c|c|}
\hline \multicolumn{2}{|c|}{ Rhone Poulenc (Rhodia) } \\
\hline 1856 & $\begin{array}{l}\text { - Marc Guilliard e Jean Marie Cartier iniciam a atividade de curtição de } \\
\text { couro para a indústria têxtil. }\end{array}$ \\
\hline 1858 & $\begin{array}{l}\text { - Fundação da empresa Wittmann et Poulenc Jeune, mais tarde denominada } \\
\text { Poulenc Frérés, para a fabricação de produtos químicos e fotográficos em } \\
\text { Paris. }\end{array}$ \\
\hline 1868 & $\begin{array}{l}\text { - Pierre Monnet funda a empresa Pierre Monnet et Cie, em La Plaine, Suíça. } \\
\text { A empresa inicia a produção de tintas de alcatrão sintético. }\end{array}$ \\
\hline 1895 & $\begin{array}{l}\text { - A empresa Gilliard, Monnet et Cartier, de Lyon, é transformada em uma } \\
\text { corporação por ações denominada La Societé Chimique des Usines du } \\
\text { Rhone ou S.C.U.R. Considera-se, de acordo com os documentos da } \\
\text { empresa, que a Rhone-Poulenc nasceu nessa data. }\end{array}$ \\
\hline $\begin{array}{l}\text { De } 1900 \text { a } \\
1909\end{array}$ & $\begin{array}{l}\text { - } \quad \text { Poulenc Frérés se transforma também em uma Corporação por ações } \\
\text { denominada Les Etablissements Poulenc Frérés. } \\
\text { • } \quad \text { A S.C.U.R. passa a deter a produção de tintas em } 1904 .\end{array}$ \\
\hline $\begin{array}{l}\text { De } 1920 \text { a } \\
1929\end{array}$ & $\begin{array}{l}\text { - As empresas Les Etablissements Poulenc Frérés e La Societé Chimique des } \\
\text { Usines du Rhone fundem-se criando uma única empresa, denominada } \\
\text { Societé des Usines Chimiques Rhone-Poulenc em } 1928 .\end{array}$ \\
\hline $\begin{array}{l}\text { De } 1930 \text { a } \\
1939\end{array}$ & $\begin{array}{l}\text { - É fundada, em 1931, a Societé Nouvelle d'applications Therapeutiques, } \\
\text { mais conhecida como Theraplix. }\end{array}$ \\
\hline $\begin{array}{l}\text { De } 1950 \text { a } \\
1959\end{array}$ & $\begin{array}{l}\text { - Ocorre em } 1956 \text { a integração entre as empresas Rhone-Poulenc e } \\
\text { Theraplix. }\end{array}$ \\
\hline $\begin{array}{l}\text { De } 1960 \text { a } \\
1969\end{array}$ & $\begin{array}{l}\text { - A Societé des Usines Chimiques Rhone-Poulenc passa a denominar-se } \\
\text { Rhone-Poulenc S.A. em } 1961 . \\
\text { - } \quad \text { O Instituto Merieux se torna parte do Rhone-Poulenc Group em } 1967 .\end{array}$ \\
\hline $\begin{array}{l}\text { De } 1980 \text { a } \\
1989\end{array}$ & $\begin{array}{l}\text { - Jean Rene Fourtou é nomeado, em 1986, presidente da Rhone-Poulenc. } \\
\text { Adquire neste ano a Nattermann e a divisão de produtos agroquímicos da } \\
\text { Union Carbide. }\end{array}$ \\
\hline
\end{tabular}




\begin{tabular}{|c|c|}
\hline & - O Instituto Mérieux adquire os Connaught Laboratories em 1989. \\
\hline $\begin{array}{l}\text { De } 1990 \text { a } \\
1999\end{array}$ & $\begin{array}{l}\text { - } \quad \text { Ocorre em } 1993 \text { a privatização da Rhone-Poulenc na França. } \\
\text { - } \quad \text { Criação da empresa de saúde animal Merial em 1997, como resultado da } \\
\text { joint venture com a Merck \& Co. dos Estados Unidos. } \\
\text { - } \quad \text { Fusão em } 1999 \text { com Hoechst AG para constituição da Aventis. }\end{array}$ \\
\hline
\end{tabular}

\section{Aventis Pharma}

\begin{tabular}{|c|c|}
\hline & $\begin{array}{l}\text { - A criação da Aventis foi efetivada em dezembro de 1999, após negociações } \\
\text { entre a alemã Hoechst Marion Roussel e a francesa Rhône Poulenc (Rhodia } \\
\text { Farma no Brasil). } \\
\text { - As duas empresas se desfizeram de seus negócios na área química e } \\
\text { concentraram a sua atuação no segmento de Ciências da Vida. } \\
\text { - A fusão entre as duas empresas permitiu uma ampliação significativa nos } \\
\text { investimentos destinados à pesquisa e desenvolvimento de novos } \\
\text { medicamentos, representando 18\% de suas vendas (aproximadamente } € 3 \\
\text { bilhões por ano). O volume de vendas também atingiu valores expressivos, } \\
\text { acima de } € 16 \text { bilhões. } \\
\text { A empresa está hoje presente em } 100 \text { países e emprega aproximadamente } \\
69 \text { mil funcionários (dos quais cerca de } 20.000 \text { na força de vendas). } \\
\text { A sua sede mundial está localizada em Estrasburgo (França) e possui } \\
\text { um.centro global de desenvolvimento de medicamentos em Bridgewater } \\
\text { (New Jersey, Estados Unidos). Possui também outros centros estratégicos } \\
\text { de pesquisa em Frankfurt (Alemanha) e em Paris (França). A Aventis conta } \\
\text { com uma equipe global de } 5.700 \text { pesquisadores, além de parcerias } \\
\text { estratégicas com inúmeras instituições acadêmicas e empresas de } \\
\text { biotecnologia. }\end{array}$ \\
\hline
\end{tabular}

\begin{tabular}{|l|ll|}
\hline \multicolumn{2}{|l|}{ Basf } \\
\hline 1865 & $\bullet \quad$ Em Ludwigshafen, Alemanha, foi fundada a matriz da empresa. \\
\hline $\begin{array}{l}\text { De } 1900 \text { a } \\
1919 .\end{array}$ & $\begin{array}{l}\text { A pesquisa adiantada no nitrogênio e o desenvolvimento do processo de } \\
\text { Haber-Bosch introduziu uma nova fase na história da companhia e da } \\
\text { indústria química entre os anos de } 1908 \text { e 1912. }\end{array}$ \\
\hline
\end{tabular}




\begin{tabular}{|c|c|}
\hline & $\begin{array}{l}\text { - A empresa cria sua primeira representação comercial no Brasil e na } \\
\text { América do Sul, na cidade do Rio de Janeiro, em } 1911 .\end{array}$ \\
\hline $\begin{array}{l}\text { De } 1950 \text { a } \\
1959\end{array}$ & $\begin{array}{l}\text { - A empresa decidiu estabelecer uma unidade de produção própria no Brasil } \\
\text { em 1955. A cidade escolhida para esta construção foi Guaratinguetá. }\end{array}$ \\
\hline $\begin{array}{l}\text { De } 1960 \text { a } \\
1969\end{array}$ & - A empresa inicia a produção de tintas. \\
\hline $\begin{array}{l}\text { De } 1990 \text { a } \\
1999\end{array}$ & $\begin{array}{l}\text { - A empresa compromete-se com o Programa Atuação Responsável. Na } \\
\text { América do Sul, a partir de } 1999 \text { começa a realizar anualmente workshops } \\
\text { para todos os responsáveis pelo Programa na região, que devem repassar } \\
\text { procedimentos e metas regionais. }\end{array}$ \\
\hline $\begin{array}{l}\text { A partir de } \\
2000\end{array}$ & $\begin{array}{l}\text { - A Agência Brasileira de Segurança concede um prêmio à empresa em } 2003 \\
\text { pelas realizações na área de segurança do trabalho, controle de } \\
\text { emergências e meio ambiente. } \\
\text { - A Basf adquire a molécula Fipronil da Bayer Cropscience, princípio ativo } \\
\text { de produtos de alta performance como o Regent 800, líder absoluto no } \\
\text { mercado de cana-de-açúcar. } \\
\text { O plano de investimentos da BASF na região, no período e } 2004 \text { a 2008, } \\
\text { representa cerca de US\$ } 200 \text { milhões. A maioria dos negócios irá investir } \\
\text { na modernização das unidades produtivas. }\end{array}$ \\
\hline
\end{tabular}

\begin{tabular}{|c|c|}
\hline \multicolumn{2}{|c|}{ Bayer } \\
\hline 1863 & $\begin{array}{l}\text { - A Bayer inicia as suas atividades em agosto deste ano, numa modesta casa, } \\
\text { no vale do rio Wupper, onde o comerciante de corantes Friedrich Bayer e o } \\
\text { mestre tintureiro Johann Weskott instalaram uma pequena fábrica para } \\
\text { produzir corantes artificiais para tingir tecidos. }\end{array}$ \\
\hline 1867 & $\begin{array}{l}\text { - A empresa inicia a atuação de três escritórios de vendas na Alemanha e um } \\
\text { na Suíça. }\end{array}$ \\
\hline 1876 & $\begin{array}{l}\text { - A Bayer inicia a sua primeira produção fora da Alemanha, localizada em } \\
\text { Moscou. }\end{array}$ \\
\hline 1881 & $\begin{array}{l}\text { - Após o falecimento dos seus fundadores, os dirigentes da companhia } \\
\text { decidem abrir seu capital social. Dessa forma, foi constituída a Friedrich } \\
\text { Bayer \& Co., uma empresa em franca expansão, com várias fábricas e, }\end{array}$ \\
\hline
\end{tabular}




\begin{tabular}{|c|c|}
\hline & o, já com 384 colaboradores. \\
\hline 1896 & $\begin{array}{l}\text { - Dois consultores técnicos da Bayer desembarcam no Rio de Janeiro, com a } \\
\text { missão de levantar as possibilidades comerciais na jovem República. Nesse } \\
\text { mesmo ano foi fundada a primeira, e durante quinze anos, a principal } \\
\text { representante dos produtos Bayer no Brasil. }\end{array}$ \\
\hline 1899 & $\begin{array}{l}\text { - Lançado o ácido acetilsalicílico (Aspirin), que é uma das drogas de maior } \\
\text { consumo no mundo até hoje. }\end{array}$ \\
\hline $\begin{array}{l}\text { De } 1910 \text { a } \\
1919\end{array}$ & $\begin{array}{l}\text { - A empresa funda em } 1911 \text { a sua própria firma de representação comercial, } \\
\text { a Frederico Bayer \& Cia., com sede no Rio de Janeiro, que passa a } \\
\text { responder por toda a distribuição dos seus produtos no país. }\end{array}$ \\
\hline $\begin{array}{l}\text { De } 1920 \text { a } \\
1929\end{array}$ & $\begin{array}{l}\text { - Devido ao grande sucesso alcançado, foi fundada a Chimica Industrial } \\
\text { Bayer Weskott \& Cia em } 1921 \text { que, além de importar e comercializar os } \\
\text { produtos da Bayer alemã, inicia a produção local de medicamentos. }\end{array}$ \\
\hline $\begin{array}{l}\text { De } 1930 \text { a } \\
1939\end{array}$ & $\begin{array}{l}\text { - As campanhas publicitárias, arrojadas para a época, contribuíram de forma } \\
\text { decisiva para o sucesso no mercado brasileiro. } \\
\text { - O primeiro processo prático para a produção de acrilonitrila a partir do } \\
\text { acetileno foi patenteado pela Bayer em 1939, trabalho esse desenvolvido } \\
\text { por Otto Bayer e Peter Kurtz. }\end{array}$ \\
\hline $\begin{array}{l}\text { De } 1950 \text { a } \\
1959\end{array}$ & $\begin{array}{l}\text { - A empresa adquire em } 1956 \text { uma antiga fábrica de ácidos, instalada em um } \\
\text { terreno no distrito de Belford Roxo. Neste ano, o presidente mundial da } \\
\text { empresa, Dr. Ulrich Haberland, esteve no Brasil e anunciou oficialmente ao } \\
\text { presidente da República, Juscelino Kubitschek, a decisão da empresa de } \\
\text { instalar um parque fabril em Belford Roxo, inicialmente com quatro } \\
\text { fábricas: anilinas, produtos químicos intermediários, derivados de cromo e } \\
\text { defensivos agrícolas } \\
\text { - Inaugurado em junho de 1958, o conjunto industrial no distrito de Belford } \\
\text { Roxo dá origem ao moderno complexo da Bayer. Nesse mesmo ano, a } \\
\text { empresa também chega ao bairro do Socorro, em São Paulo }\end{array}$ \\
\hline $\begin{array}{l}\text { De } 1970 \text { a } \\
1979\end{array}$ & $\begin{array}{l}\text { - É transferida, em 1973, a sede administrativa da empresa para a unidade de } \\
\text { São Paulo no bairro de Socorro. }\end{array}$ \\
\hline $\begin{array}{l}\text { De } 1990 \text { a } \\
1999\end{array}$ & $\begin{array}{l}\text { - Depois de várias mudanças, em 1992, o nome da empresa passa a ser Bayer } \\
\text { S.A. }\end{array}$ \\
\hline
\end{tabular}




\begin{tabular}{|l|l|}
\hline & $\begin{array}{l}\text { A Bayer adquire a CPB - Central de Polímeros da Bahia em } 1997 . \\
\text { • A Bayer investe aproximadamente US\$ } 25 \text { milhões em } 1999 \text { e inaugura }\end{array}$ \\
& $\begin{array}{l}\text { uma nova fábrica na área farmacêutica, trazendo modernas tecnologias e } \\
\text { equipamentos para o Brasil, hoje com capacidade de abastecer todo o } \\
\text { Mercosul. }\end{array}$ \\
\hline 2000 & $\begin{array}{l}\text { Com a compra dos negócios de poliol da empresa americana Lyondell } \\
\text { Chemical Company, no início de 2000, a Bayer assegura ainda mais a }\end{array}$ \\
& $\begin{array}{l}\text { liderança em poliuretano. Vale a pena destacar que o Poliuretano foi } \\
\text { descoberto no início dos anos } 30 \text { nos laboratórios da Bayer, na Alemanha. } \\
\text { Compra da divisão de agribusiness da Aventis Crop Science. }\end{array}$ \\
\hline
\end{tabular}

\begin{tabular}{|c|c|}
\hline Solvay & \\
\hline 1861 & $\begin{array}{l}\text { - A história do Grupo Solvay inicia-se em } 15 \text { Abril 1861, quando Ernest } \\
\text { Solvay (1838-1922) patenteia a produção industrial de amônia , dióxido de } \\
\text { carbono (CO2) e limão. }\end{array}$ \\
\hline 1865 & $\begin{array}{l}\text { - É aberta na Bélgica a primeira usina de soda da Solvay carbonato de sódio, } \\
\text { usando sal comum. }\end{array}$ \\
\hline 1898 & $\begin{array}{l}\text { - Com a demanda de soda cáustica crescendo, a Solvay começa a produzi-la } \\
\text { pela eletrólise da salmoura, um processo que também produz cloro e } \\
\text { hidrogênio. Vendo espaço para a diversificação, a eletrólise foi substituindo } \\
\text { as unidades de caustificação. }\end{array}$ \\
\hline $\begin{array}{l}\text { De } 1910 \text { a } \\
1919\end{array}$ & $\begin{array}{l}\text { - Instalada em } 1912 \text { a Companhia Brasileira de Carbureto de Cálcio, } \\
\text { pertencente ao grupo Solvay. }\end{array}$ \\
\hline $\begin{array}{l}\text { De } 1940 \text { a } \\
1949\end{array}$ & $\begin{array}{l}\text { - A empresa instala a sua sede administrativa na cidade de Santo André, } \\
\text { onde permanece até hoje. }\end{array}$ \\
\hline $\begin{array}{l}\text { De } 1950 \text { a } \\
1959\end{array}$ & $\begin{array}{l}\text { - O grupo começa a produzir e vender várias classes do polietileno de alta } \\
\text { densidade em } 1959 . \\
\text { - Devido ao interesse e experiência da empresa em atividades de química } \\
\text { orgânica, o grupo passa a fazer investimentos nesta década na área de } \\
\text { ciências da vida. }\end{array}$ \\
\hline $\begin{array}{l}\text { De } 1990 \text { a } \\
1999\end{array}$ & $\begin{array}{l}\text { - A Solvay compra 51\% do capital da Indupa em 1996, constituindo a } \\
\text { empresa Solvay Indupa SAIC. }\end{array}$ \\
\hline
\end{tabular}




\begin{tabular}{|l|l|}
\hline & $\begin{array}{l}\text { A Solvay Indupa SAIC adquire os negócios de cloro, soda, e PVC da } \\
\text { Solvay do Brasil formando a empresa Solvay Indupa do Brasil SA. }\end{array}$ \\
\hline $\begin{array}{l}\text { A partir de } \\
2000\end{array}$ & $\begin{array}{l}\text { A Solvay atinge em } 2001 \text { um faturamento bruto mundial recorde de 8,7 } \\
\text { bilhões de euros. } \\
\text { A empresa associa-se a Dacarto-Benvic em 2004. }\end{array}$ \\
\hline
\end{tabular}

\begin{tabular}{|c|c|}
\hline \multicolumn{2}{|l|}{ DuPont } \\
\hline 1788 & $\begin{array}{l}\text { - Eleuthère Irénée du Pont de Nemours, aos } 16 \text { anos, trabalha como aprendiz } \\
\text { de químico no laboratório de Antoine Lavoisier, em Essone, França. Ele } \\
\text { ganha rapidamente experiência na manufatura de pólvora. }\end{array}$ \\
\hline 1802 & $\begin{array}{l}\text { - Após mudar-se Essone, França para Delaware nos Estados Unidos, } \\
\text { Eleuthère Irénée du Pont compra uma propriedade em Brandywine River e } \\
\text { inicia a construção de sua própria fábrica de pólvora, a Eleutherian Mills. }\end{array}$ \\
\hline 1804 & • É iniciada a produção e a venda de pólvora pela empresa. \\
\hline 1805 & - Ocorrem as primeiras exportações da empresa, com destino para a Espanha. \\
\hline 1811 & $\begin{array}{l}\text { - A produção anual da empresa atinge o recorde de } 204.506 \text { libras de pólvora } \\
\text { e as vendas brutas chegam ao valor US\$122.006. A DuPont passa a ser } \\
\text { considerada a maior fabricante de pólvora da América. }\end{array}$ \\
\hline 1857 & $\begin{array}{l}\text { - O neto de Eleuthère Irénée, Lammot du Pont, recebe patente por melhoria } \\
\text { de pólvora. Sua nova fórmula de pólvora, feita de nitrato de sódio, é mais } \\
\text { barata do que a tradicional pólvora de nitrato de potássio. }\end{array}$ \\
\hline 1861 & $\begin{array}{l}\text { - Lammot du Pont inicia a construção de uma fábrica chamada Repauno, em } \\
\text { Gibbstown, New Jersey, para produzir dinamite, um explosivo três vezes } \\
\text { mais potente do que a tradicional pólvora negra. A construção é concluída } \\
\text { em } 1865 .\end{array}$ \\
\hline $\begin{array}{l}\text { De } 1900 \mathrm{a} \\
1909\end{array}$ & $\begin{array}{l}\text { - Quando o presidente da empresa Eugene du Pont morre em 1902, os sócios } \\
\text { restantes decidem vender a empresa ao maior licitante. Três bisnetos do } \\
\text { fundador - Thomas Coleman du Pont, Alfred Irénée du Pont e Pierre } \\
\text { Samuel du Pont - compram a companhia. } \\
\text { - Os primos fazem planos para conduzir a DuPont em novas direções. Eles } \\
\text { abrem também em 1902, o Eastern Laboratory, um dos primeiros } \\
\text { laboratórios industriais do país. }\end{array}$ \\
\hline
\end{tabular}




\begin{tabular}{|c|c|}
\hline & $\begin{array}{l}\text { - Considerado o segundo maior centro de pesquisa, a Experimental Station se } \\
\text { estabelece em } 1903 \text { próxima às antigas fábricas de pólvora em Brandywine } \\
\text { para usar o conhecimento da empresa na química de celulose e diversificar } \\
\text { o seu produto base. } \\
\text { - A DuPont começa a ampliar o seu portfolio de produtos em 1904, passando } \\
\text { a atuar na manufatura de vernizes e de outros produtos não explosivos. }\end{array}$ \\
\hline $\begin{array}{l}\text { De } 1910 \text { a } \\
1919\end{array}$ & $\begin{array}{l}\text { - Durante a Primeira Guerra Mundial, a DuPont fornece significativa } \\
\text { quantidade de explosivos militares às Forças Aliadas e supre a indústria dos } \\
\text { Estados Unidos com pelo menos metade do total requerido pela nação para } \\
\text { uso em mineração e construção pesada. } \\
\text { - A DuPont entra na indústria de tingimento em 1917, antes monopolizada } \\
\text { por empresas alemãs. A empresa monta o Jackson Laboratory e uma fábrica } \\
\text { para a produção de materiais de tingimento em Deepwater Point, New } \\
\text { Jersey. }\end{array}$ \\
\hline $\begin{array}{l}\text { De } 1920 \text { a } \\
1929\end{array}$ & $\begin{array}{l}\text { - A empresa compra em } 1920 \text { o processo de produção de viscose rayon da } \\
\text { Comptoir des Textiles Artificiels e constitui a DuPont Fibersilk Company, } \\
\text { mais tarde denominada DuPont Rayon Company. } \\
\text { - A DuPont Cellophane Co. Inc. é constituída em 1923, após a DuPont } \\
\text { adquirir os direitos de uma empresa francesa para fabricar celofane. } \\
\text { Em 1927, o pesquisador Hale Charch, da DuPont, produz o celofane à } \\
\text { prova de umidade, transformando-o de um material de embalagem } \\
\text { eficiente. } \\
\text { A pesquisa em filmes e vernizes propicia a produção de uma tinta } \\
\text { automobilística nova e de secagem rápida chamada Duco, que agiliza a } \\
\text { produção e dá ao consumidor a possibilidade de escolha a partir de uma } \\
\text { nova gama de cores. }\end{array}$ \\
\hline $\begin{array}{l}\text { De } 1930 \text { a } \\
1939\end{array}$ & $\begin{array}{l}\text { - Os pesquisadores da DuPont, Arnold Collins e Wallace Carothers, } \\
\text { descobrem nova borracha sintética de uso geral denominada neoprene. } \\
\text { Exatamente duas semanas mais tarde, o pesquisador Julian Hill descobre a } \\
\text { primeira fibra sintética, uma percursora do nylon. } \\
\text { - O Haskell Laboratory of Industrial Toxicology é construído na }\end{array}$ \\
\hline
\end{tabular}




\begin{tabular}{|c|c|}
\hline & $\begin{array}{l}\text { Experimental Station em 1934. Finalizado em 1935, o laboratório inicia } \\
\text { suas atividades com uma equipe de } 20 \text { funcionários. } \\
\text { - Os pesquisadores Gerald Berchet e Wallace Carothers descobrem o nylon } \\
\text { em 1935, considerada uma nova seda sintética. } \\
\text { - Depois de anos de intenso desenvolvimento, o nylon finalmente é } \\
\text { anunciado ao público, na Feira Mundial de 1939, em New York. } \\
\text { Pesquisadores descobrem entre os anos de 1937 e } 1938 \text { o Teflon, uma } \\
\text { plástico que intercala as camadas de vidros de segurança de automóveis; e } \\
\text { as resinas acrílicas Lucite. }\end{array}$ \\
\hline $\begin{array}{l}\text { De } 1940 \text { a } \\
1949\end{array}$ & $\begin{array}{l}\text { - A DuPont contribui, entre os anos de } 1941 \text { e 1945, para o Projeto } \\
\text { Manhattan, considerado altamente secreto, para projetar construir e operar } \\
\text { a fábrica produtora de plutônio Hanford, em Washington e a fábrica piloto } \\
\text { Oak Bridge, no Tennessee. } \\
\text { - A empresa onstrói e opera para o governo a fábrica de neoprene, } \\
\text { juntamente com uma unidade produtora de amônia-metanol, duas unidades } \\
\text { de Suprimento Químico Militar e outra de produtos químicos para Marinha. } \\
\text { A DuPont produz novamente significativa quantidade de explosivos } \\
\text { militares, assim como nylon para pára-quedas e tendas, cordas e outros } \\
\text { suprimentos militares durante a II Guerra Mundial. } \\
\text { A produção de nylon foi interrompida pela II Guerra Mundial e, quando as } \\
\text { lojas começaram a apresentar as promissoras meias finas após a guerra em } \\
\text { 1946, houve um crescimento significativo na demanda por este tipo de } \\
\text { produto chegando a gerar, segundo documentos da empresa, enormes filas e } \\
\text { tumultos para a sua aquisição. }\end{array}$ \\
\hline $\begin{array}{l}\text { De } 1950 \text { a } \\
1959\end{array}$ & $\begin{array}{l}\text { - A empresa desenvolve o filme de poliéster Mylar em 1952, um filme } \\
\text { plástico, durável e resistente para ser utilizado em diferentes produtos, } \\
\text { desde fitas de gravação até aquelas usadas para isolamento elétrico. } \\
\text { - Ainda em 1952, novos sintéticos resistentes a rugas, do tipo lavar-e-usar, } \\
\text { como o poliéster Dacron e a fibra acrílica Orlon, ambos marcas registradas } \\
\text { DuPont, contribuem para o espetacular sucesso do Departamento de Fibras } \\
\text { Têxteis recentemente formado. }\end{array}$ \\
\hline
\end{tabular}




\begin{tabular}{|c|c|}
\hline & $\begin{array}{l}\text { - O Departamento Internacional é aberto em } 1958 \text { e a companhia começa a } \\
\text { fazer pesados investimentos externos. } \\
\text { - É introduzida a fibra elastano da marca Lycra da DuPont em } 1959 .\end{array}$ \\
\hline 1969 & $\begin{array}{l}\text { - Novos produtos de isolamento como o material de proteção Tyvek, e a } \\
\text { fibra Nomex, marcas registradas DuPont, começam a ser produzidos em } \\
\text { 1967. Tyvek é resistente e durável, usado para embalagem, envelopes, } \\
\text { banners, roupas de proteção e isolamento de construções. As fibras } \\
\text { resistentes ao fogo Nomex são são utilizadas como roupas de proteção, } \\
\text { mangueiras de alta performance e uso em altas temperaturas elétricas. } \\
\text { - O filme Riston, marca registrada da DuPont, é comercializado, melhorando } \\
\text { consideravelmente a produtividade de quadros de fiação impressa. } \\
\text { É desenvolvido em } 1969 \text { o material de superfície Corian, também marca } \\
\text { registrada da DuPont. É um material não poroso para bancadas, bacias e } \\
\text { outros usos em construção, que resiste a manchas, arranhões e } \\
\text { queimaduras. } \\
\text { A empresa orgulha-se ao anunciar em } 1969 \text { que a reupa espacial utilizada } \\
\text { pelo homem na Lua contém significativa quantidade de materiais da } \\
\text { DuPont (23 das } 25 \text { camadas presentes na referida roupa) } \\
\text { Ainda em 1969, roupas à prova de bala produzidas com a fibra aramida } \\
\text { Kevlar, marca registrada DuPont, são testadas por } 15 \text { departamentos de } \\
\text { polícia. }\end{array}$ \\
\hline & $\begin{array}{l}\text { - A DuPont compra a Conoco Inc. em 1981, companhia de petróleo, } \\
\text { praticamente dodbrando seus ativos e rendimentos. Os US\$ } 8 \text { bilhões } \\
\text { relacionados ao valor da aquisição ficaram na lista das maiores operações } \\
\text { da história dos Estados Unidos na época. } \\
\text { - A empresa amplia sua linha de produtos agrícolas com o desenvolvimento } \\
\text { de Glean em 1982, um dos herbicidas da nova geração que reduz custos e } \\
\text { toxicidade. } \\
\text { - Charles Pedersen ganha o Prêmio Nobel de Química em } 1987 .\end{array}$ \\
\hline $\begin{array}{l}\text { De } 1990 \text { a } \\
1999\end{array}$ & $\begin{array}{l}\text { - A DuPont assina um contrato de sociedade com a Merck na área } \\
\text { farmacêutica em } 1990 . \\
\text { - Como parte da estratégia da companhia de investir em biotecnologia, a }\end{array}$ \\
\hline
\end{tabular}




\begin{tabular}{|c|c|}
\hline & $\begin{array}{l}\text { DuPont adquire em } 1997 \text { uma participação na Pioneer Hi-Bred } \\
\text { International, o maior fornecedor mundial de sementes. } \\
\text { • } \quad \text { Ainda em 1997, a empresa dquire a Protein Technologies International, um } \\
\text { dos maiores fornecedores de proteínas de soja. } \\
\text { A DuPont adquire a participação da Merck na joint-venture formada pelas } \\
\text { tratamento uma denominado “uma vez ao dia” para HIV e AIDS. } \\
\text { O FDA (Food and Drug Administration), dos Estados Unidos, aprova em } \\
\text { 1999 a petição da DuPont referente a uma reivindicação de saúde nos } \\
\text { rótulos de alimentos, que garanta a associação entre a proteína de soja e a } \\
\text { redução de risco de doenças coronárias. } \\
\text { Empresas de alimentos iniciam o uso da marca de soja Supro, marca } \\
\text { registrada DuPont, tendo como ingrediente proteínas isoladas de soja. } \\
\text { A empresa adquire em } 1999 \text { a Herberts, a empresa de revestimentos da } \\
\text { Hoechst. }\end{array}$ \\
\hline $\begin{array}{l}\text { A partir de } \\
2000\end{array}$ & $\begin{array}{l}\text { - Sorona, marca registrada da DuPont, é o nome dado à tecnologia 3GT, a } \\
\text { plataforma mais avançada de polímeros no portfólio de ciência da } \\
\text { companhia em 2000. A DuPont trabalha com um número limitado de sócios } \\
\text { para implementar a tecnologia de fabricação de fibras de Sorona. } \\
\text { - A DuPont vende o negócio Farmacêutico para a Bristol-Myers Squibb em } \\
2001 . \\
\text { - A empresa celebra em } 2002 \text { seu aniversário de } 200 \text { anos e anuncia a } \\
\text { reestruturação global de seus negócios, com a criação da subsidiária } \\
\text { DuPont Textiles \& Interiors e cinco plataformas de crescimento: DuPont } \\
\text { Tecnologias - Eletrônica e Comunicação; DuPont Materiais de } \\
\text { Performance; DuPont Tecnologias - Cor e Revestimento; DuPont } \\
\text { Segurança e Proteção; DuPont Agricultura e Nutrição. } \\
\text { Dando continuidade a este processo de reestruturação, ainda em 2002, a } \\
\text { DuPont Performance Coatings adquire o controle integral da Renner } \\
\text { DuPont. }\end{array}$ \\
\hline
\end{tabular}




\begin{tabular}{|l|l|}
\hline & $\begin{array}{l}\text { É anunciada a aliança global entre a DuPont Protein Technologies e a } \\
\text { Bunge, dando início às operações da joint-venture Solae Company em } \\
2003 . \\
\text { A DuPont Textiles \& Interiors adquire o controle integral da Fibra DuPont, } \\
\text { antiga joint-venture com o Grupo Vicunha também em } 2003 .\end{array}$ \\
\hline
\end{tabular}

\begin{tabular}{|c|c|}
\hline \multicolumn{2}{|l|}{ Monsanto } \\
\hline $\begin{array}{l}\text { De } 1900 \text { a } \\
1909\end{array}$ & $\begin{array}{l}\text { - A empresa é constituída, em St. Louis, no Missouri, Estados Unidos, para } \\
\text { fabricar sacarina, um tipo de adoçante artificial. Denomina-se Monsanto } \\
\text { Chemical Works, em homenagem à esposa de John F. Queeny, fundador e } \\
\text { agente de compras da Meyer Brothers Drug Company. } \\
\text { - A tecnologia de fabricação é licenciada por uma empresa suíça, a } \\
\text { Companhia Sandoz. }\end{array}$ \\
\hline $\begin{array}{l}\text { De } 1910 \text { a } \\
1911\end{array}$ & $\begin{array}{l}\text { - A Primeira Guerra Mundial traz fortes mudanças. Por causa da falta de } \\
\text { homens na sua linha de produção, a Monsanto tem que contratar cerca de } \\
125 \text { mulheres em St. Louis. } \\
\text { - Nesse período, adquire a Commercial Acid Co., também de St. Louis, } \\
\text { negócio estratégico uma vez que acrescenta materiais intermediários à linha } \\
\text { de produção, como os ácidos sulfúrico, nítrico e hidroclorífico, farelo de sal, } \\
\text { cloreto de zinco, ácido clorosulfórico e sulfato de sódio. }\end{array}$ \\
\hline $\begin{array}{l}\text { De } 1920 \text { a } \\
1929\end{array}$ & $\begin{array}{l}\text { - Como ocorre em muitas empresas americanas, o término da guerra deixa a } \\
\text { Monsanto com excesso de estoque e grande capacidade ociosa. Entre outras } \\
\text { providências, o presidente e diretor do Conselho de Administração, John F. } \\
\text { Queeny, vende uma parte de sua participação acionária e abre mão de seu } \\
\text { controle majoritário no Conselho. } \\
\text { - As ações da empresa são colocadas à venda na Bolsa de Nova York. }\end{array}$ \\
\hline $\begin{array}{l}\text { De } 1940 \text { a } \\
1949\end{array}$ & $\begin{array}{l}\text { - A Monsanto Chemical Co. Dedica-se à construção de quatro fábricas, } \\
\text { incluindo uma usina para produzir monômero de estireno para o processo } \\
\text { produtivo de borracha sintética. } \\
\text { - A empresa passa a produzir e comercializar uma série de produtos } \\
\text { químicos para o setor agrícola, com os inseticidas Parathion e Santobane. }\end{array}$ \\
\hline De 1950 a & - A empresa inicia a comercialização de suas matérias-primas no Brasil e no \\
\hline
\end{tabular}




\begin{tabular}{|c|c|}
\hline 1959 & $\begin{array}{l}\text { Japão. } \\
\text { - Lança, neste período, dois novos herbicidas para controle de gramíneas } \\
\text { anuais e de ervas daninhas: Randox e Vegadex, com marcas registradas, } \\
\text { para controle de pragas indesejáveis }\end{array}$ \\
\hline $\begin{array}{l}\text { De } 1960 \text { a } \\
1969\end{array}$ & - Éc \\
\hline $\begin{array}{l}\text { De } 19 \\
1979\end{array}$ & $\begin{array}{l}\text { - } \quad \text { A Monsanto sintetiza o glifosato, princípio ativo do herbicida Roundup. } \\
\text { - O glifosato revela propriedades atraentes: não afeta o solo, não se acumula } \\
\text { no meio ambiente e não é tóxico para os animais. } \\
\text { - Início de produção na primeira fábrica da Monsanto no Brasil, em São José } \\
\text { dos Campos (SP) }\end{array}$ \\
\hline $\begin{array}{l}\text { De } 1980 \text { a } \\
1989\end{array}$ & $\begin{array}{l}\text { - } \quad \text { A biotecnologia passa a ser o foco das pesquisas da Monsanto. } \\
\text { - } \quad \text { Com a aquisição da G. D. Searle, a Monsanto passa a atuar também no } \\
\text { setor de adoçantes e farmacêutico. } \\
\text { - } \quad \text { A Monsanto compra a NutraSweet no Brasil. }\end{array}$ \\
\hline $\begin{array}{l}\text { De } 1990 \text { a } \\
1999\end{array}$ & $\begin{array}{l}\text { • Produtos geneticamente modificados começam a ser aprovados para } \\
\text { comercialização nos Estados Unidos. } \\
\text { - São adquiridas as empresas de sementes Calgene, Asgrow, Monsoy e } \\
\text { - A compalb. } \\
\text { biotecnologia e à indústria farmacêutica permanecem sob a razão social } \\
\text { Monsanto, uma empresa totalmente independente. } \\
\text { Os negócios da área química são desmembrados e reúnem-se sob a razão } \\
\text { - É inaugurad Solutia. } \\
\text { produção de herbicidas granulados. }\end{array}$ \\
\hline $\begin{array}{l}\text { A partir de } \\
2000\end{array}$ & $\begin{array}{l}\text { - A fusão entre Monsanto e Pharmacia \& Upjohn dá origem à Pharmacia } \\
\text { Corporation. A razão social Monsanto é mantida para a subsidiária agrícola } \\
\text { da nova companhia. } \\
\text { - A empresa lança suas ações na Bolsa de Valores de Nova York. } \\
\text { - Inaugurado o Complexo de Sementes de Uberlândia (MG), dedicado à } \\
\text { pesquisa e ao beneficiamento de sementes de milho e sorgo, com }\end{array}$ \\
\hline
\end{tabular}




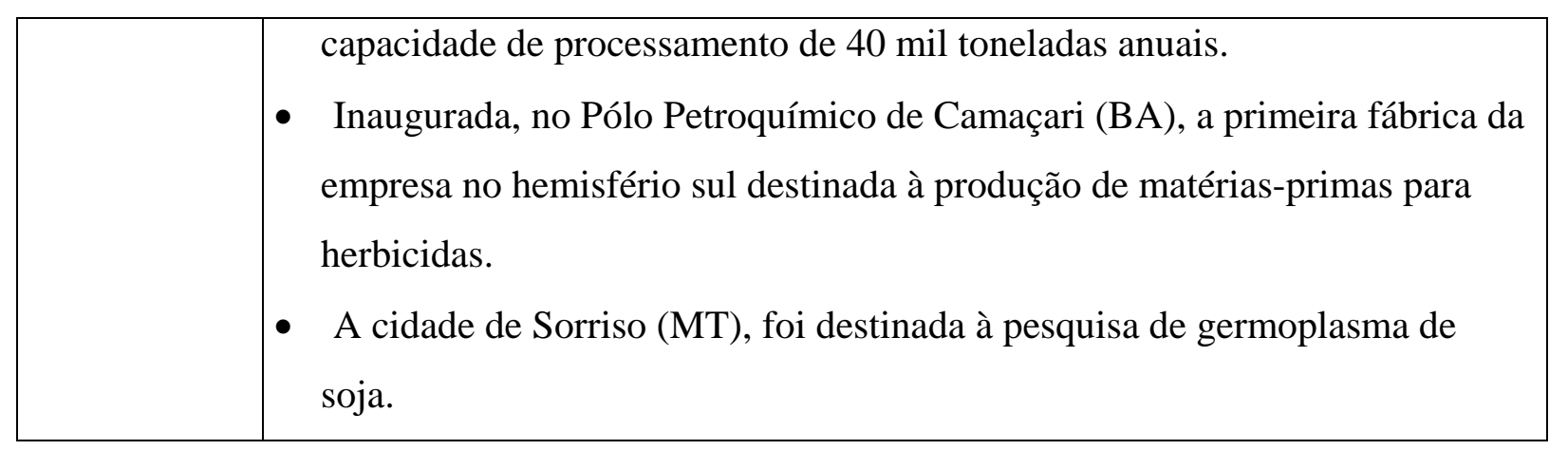




\section{APÊNDICE B: ROTEIRO DAS ENTREVISTAS SEMI-ESTRUTURADAS APLICADO JUNTO AOS PROFISSIONAIS DA EMPRESA}

\section{Section A: Background}

- What was the specific work you were involved in/responsible for in the acquisitions?

- How clear a view did you have of what success for this acquisition looked like?

- How was information managed and shared across the team during the process?

- What have you learned from this experience? What would you do differently if you were to do this acquisition again? What would you do the same again? What learning is there for another, different acquisition?

\section{Section B: Acquisition phases}

\begin{tabular}{|c|c|c|}
\hline Phase name & What went well? & $\begin{array}{c}\text { What could be } \\
\text { improved? }\end{array}$ \\
\hline $\begin{array}{l}\text { 1. Strategic planning } \\
\text { 2. Opportunities identification } \\
\text { 3. Opportunities evaluation } \\
\text { 4. Negotiation and deal execution } \\
\text { 5. Post-acquisition integration }\end{array}$ & & \\
\hline
\end{tabular}

\section{Section C: Overall process}

- Was the process as you expected?

- Did the acquisition team accomplish its mission?

- What helped and what hindered the team?

- Which elements should be developed in the integration phase aiming at ensuring effectiveness for future acquisitions?

- What advice would you give to other teams?

- Is there anything else you would like to add? 


\section{APÊNDICE C1: MODELO DO QUESTIONÁRIO - VERSÃO ORIGINAL EM INGLÊS}

\begin{tabular}{|c|l|}
\hline $\mathbf{1}$ & My legacy company is: \\
\hline 1 A & Company Alfa \\
\hline 1 B & Company Beta \\
\hline 1 C & Company Gama \\
\hline 1 D & I'm new to the company \\
\hline
\end{tabular}

\begin{tabular}{|c|l|}
\hline $\mathbf{2}$ & I work mainly in the following area: \\
\hline $2^{\text {a }}$ & Commercial team Alfa brand \\
\hline $2 \mathrm{~B}$ & Commercial team Beta brand \\
\hline $2 \mathrm{C}$ & Commercial team Gama brand \\
\hline $2 \mathrm{D}$ & Commercial team other brands \\
\hline $2 \mathrm{E}$ & Administratives \\
\hline $2 \mathrm{~F}$ & Supply chain \\
\hline $2 \mathrm{G}$ & Research and development \\
\hline
\end{tabular}

\begin{tabular}{|c|l|}
\hline $\mathbf{3}$ & I consider myself management: \\
\hline 3 A & Yes \\
\hline 3 B & No \\
\hline
\end{tabular}

Proposed scale for the following questions

(4) Strongly agree

(3) Agree

(2) Disagree

(1) Strongly disagree

(0) Neutral/ Don't know

\begin{tabular}{|c|c|}
\hline 4 & Questions about the acquisitions: \\
\hline $4 \mathrm{~A}$ & I know and understand the strategy of the acquisitions. \\
\hline $4 \mathrm{~B}$ & $\begin{array}{l}\text { I know the economic drivers that will make the acquisitions create value for Alfa } \\
\text { shareholders. }\end{array}$ \\
\hline $4 \mathrm{C}$ & The decision to implement a multi-brand strategy is a good one. \\
\hline $4 \mathrm{D}$ & Decisions taken to date support the multi-brand strategy. \\
\hline 5 & Your comments, if any, on the above responses: \\
\hline
\end{tabular}

\begin{tabular}{|c|l|}
\hline $\mathbf{6}$ & I am optimistic about: \\
\hline 6 A & Our ability to introduce new, high performing genetics. \\
\hline 6 B & Our ability to deliver new, in-demand traits. \\
\hline 6 C & Our ability to differentiate the three company brands. \\
\hline 6 D & Our ability to produce and deliver products timely. \\
\hline
\end{tabular}

\begin{tabular}{l|l}
$\mathbf{7}$ & Your comments, if any, on the above responses:
\end{tabular} 


\begin{tabular}{|c|l|}
\hline $\mathbf{8}$ & I am confident in: \\
\hline 8 A & The Company Leadership Team's ability to deliver what is needed to succeed. \\
\hline 8 B & My function's Leadership Team's ability to deliver what is needed to succeed. \\
\hline 8 C & My function's organization's ability to deliver what is needed to succeed. \\
\hline 8 D & My ability to deliver what is needed to succeed. \\
\hline
\end{tabular}

\begin{tabular}{|c|l|}
\hline $\mathbf{9}$ & Your comments, if any, on the above responses: \\
\hline $\mathbf{1 0}$ & Based upon my experience, I believe: \\
\hline $10 \mathrm{~A}$ & The "business" integration process has been fair and objective. \\
\hline $10 \mathrm{~B}$ & The "personnel" integration process has been fair and objective. \\
\hline $10 \mathrm{C}$ & Overall, key integration decisions were timely. \\
\hline $10 \mathrm{D}$ & Key personnel decisions were timely. \\
\hline $10 \mathrm{E}$ & Product Development site location decisions were timely. \\
\hline $10 \mathrm{~F}$ & Supply Chain site location decisions were timely. \\
\hline $10 \mathrm{G}$ & Headquarters and brand site location decisions were timely. \\
\hline $10 \mathrm{H}$ & I knew my personal status with the company as soon as feasible. \\
\hline
\end{tabular}

\begin{tabular}{|c|l|}
\hline $\mathbf{1 1}$ & Your comments, if any, on the above responses: \\
\hline $\mathbf{1 2}$ & Your thoughts on the integration communications: \\
\hline $12 \mathrm{~A}$ & Communications has been as open as it could be. \\
\hline $12 \mathrm{~B}$ & Communications has been timely. \\
\hline $12 \mathrm{C}$ & The amount (quantity) of communication was sufficient. \\
\hline $12 \mathrm{D}$ & Communications about new functional organizations have met my needs. \\
\hline $12 \mathrm{E}$ & My manager kept me informed about the integration plans that affected me. \\
\hline $12 \mathrm{~F}$ & $\begin{array}{l}\text { The communications and coordination between functional integration teams } \\
\text { successful. }\end{array}$ \\
\hline
\end{tabular}

\begin{tabular}{|c|l|}
\hline $\mathbf{1 3}$ & Your comments, if any, on the above responses: \\
\hline
\end{tabular}

\begin{tabular}{|c|c|}
\hline 14 & The staffing process for the new organization: \\
\hline $14 \mathrm{~A}$ & $\begin{array}{l}\text { Information regarding what positions would be available in my function was } \\
\text { well organized and handled appropriately. }\end{array}$ \\
\hline $14 \mathrm{~B}$ & Applying for these new positions was well organized and handled appropriately. \\
\hline $14 \mathrm{C}$ & Interviewing for these positions was well organized and handled appropriately. \\
\hline $14 \mathrm{D}$ & I changed positions during the integration and the terms were appropriate. \\
\hline $14 \mathrm{E}$ & $\begin{array}{l}\text { I relocated (or will relocate) during the integration and the terms were } \\
\text { satisfactory. }\end{array}$ \\
\hline $14 \mathrm{~F}$ & If I had questions about my compensation, answers were adequate. \\
\hline $14 \mathrm{G}$ & Employee benefits \& payroll roll-outs were successful. \\
\hline 15 & Your comments, if any, on the above responses: \\
\hline
\end{tabular}




\begin{tabular}{|c|l|}
\hline $\mathbf{1 6}$ & Integration coordination and management: \\
\hline $16 \mathrm{~A}$ & I knew who my integration team was and what they were assigned to do. \\
\hline $16 \mathrm{~B}$ & My function's integration team was thorough, effective and communicative. \\
\hline $16 \mathrm{C}$ & $\begin{array}{l}\text { My function's integration team appears to have the resources to carry out the } \\
\text { integration successfully. }\end{array}$ \\
\hline $16 \mathrm{D}$ & Key integration activities coming up in the next few months are well planned. \\
\hline $16 \mathrm{E}$ & $\begin{array}{l}\text { Employees who were told that they would not have positions were treated } \\
\text { respectfully. }\end{array}$ \\
\hline $16 \mathrm{~F}$ & $\begin{array}{l}\text { I know my function's new organization structure and who is accountable for key } \\
\text { deliverables. }\end{array}$ \\
\hline $16 \mathrm{G}$ & I understand the integration cost synergy (savings) targets. \\
\hline $16 \mathrm{H}$ & I believe the integration cost synergy (savings) targets are achievable. \\
\hline $16 \mathrm{I}$ & My manager supports the integration process. \\
\hline
\end{tabular}

17 Your comments, if any, on the above responses:

\begin{tabular}{|c|l|}
\hline $\mathbf{1 8}$ & Thoughts on what you and your peers are thinking: \\
\hline $18 \mathrm{~A}$ & Thus far, the integration is successful. \\
\hline $18 \mathrm{~B}$ & My peers are satisfied with the integration thus far. \\
\hline $18 \mathrm{C}$ & We are managing to retain our key employees during the integration. \\
\hline $18 \mathrm{D}$ & We will continue to retain our key employees in the next six months. \\
\hline $18 \mathrm{E}$ & The workload during the integration was manageable. \\
\hline $18 \mathrm{~F}$ & I'm beginning to identify with my role in the new organization. \\
\hline $18 \mathrm{G}$ & My peers are beginning to identify with their roles in the new organization. \\
\hline $18 \mathrm{H}$ & Right now employees have sufficient energy to make the integration successful. \\
\hline
\end{tabular}

19 Your comments, if any, on the above responses:

\begin{tabular}{|c|l|}
\hline $\mathbf{2 0}$ & Your understanding of our goals and direction: \\
\hline $20 \mathrm{~A}$ & I know the expectations of me going forward. \\
\hline $20 \mathrm{~B}$ & The expectations of me going forward are reasonable. \\
\hline $20 \mathrm{C}$ & I understand the key operating goals in my function. \\
\hline $20 \mathrm{D}$ & I understand the key financial targets in my function. \\
\hline $20 \mathrm{E}$ & $\begin{array}{l}\text { My manager has been clear on what is going to change because of the } \\
\text { integration and why. }\end{array}$ \\
\hline
\end{tabular}

\section{Your comments, if any, on the above responses:}

\begin{tabular}{|c|l|}
\hline 22 & Additional questions \\
\hline 22 A & We know where we are going in my function and how to get there. \\
\hline 22 B & We are finding new and better ways of doing things, not just the same old way. \\
\hline 22 C & I feel confident about our competitiveness in the industry. \\
\hline 22 D & I believe I'm on a winning team. \\
\hline 22 E & We are becoming more innovative. \\
\hline 22 F & Standard and operating processes and procedures are evolving and are on target. \\
\hline
\end{tabular}




\section{APÊNDICE C2: MODELO DO QUESTIONÁRIO - VERSÃO TRADUZIDA PARA O PORTUGUÊS}

\begin{tabular}{|c|l|}
\hline $\mathbf{1}$ & Minha empresa original é: \\
\hline $1 \mathrm{~A}$ & Empresa Alfa \\
\hline 1B & Empresa Beta \\
\hline 1C & Empresa Gama \\
\hline $1 \mathrm{D}$ & Sou novo na empresa \\
\hline
\end{tabular}

\begin{tabular}{|c|l|}
\hline $\mathbf{2}$ & Trabalho principalmente nas seguintes areas: \\
\hline $2 \mathrm{~A}$ & Equipe comercial da marca Alfa \\
\hline 2B & Equipe comercial da marca Beta \\
\hline 2C & Equipe comercial da marca Gama \\
\hline 2D & Equipe comercial de outras marcas \\
\hline $2 \mathrm{E}$ & Administrativos \\
\hline $2 \mathrm{~F}$ & Cadeia de suprimentos \\
\hline $2 \mathrm{G}$ & Pesquisa e desenvolvimento \\
\hline
\end{tabular}

\begin{tabular}{|c|l|}
\hline $\mathbf{3}$ & Me considero participante do nível gerencial: \\
\hline 3A & Sim \\
\hline 3B & Não \\
\hline
\end{tabular}

Escala proposta para as próximas questões

(4) Concordo fortemente

(3) Concordo

(2) Discordo

(1) Discordo fortemente

(0) Não sei

\begin{tabular}{|c|l|}
\hline $\mathbf{4}$ & Questões sobre as aquisições: \\
\hline 4A & Conheço e compreendo a estratégia de aquisições da empresa. \\
\hline 4B & $\begin{array}{l}\text { Conheço as razões que fazem as aquisições da empresa Alfa gerarem valor para } \\
\text { os acionistas. }\end{array}$ \\
\hline 4C & $\begin{array}{l}\text { Considero boa a idéia de implementar uma estratégia de complementação de } \\
\text { portfolio. }\end{array}$ \\
\hline 4D & $\begin{array}{l}\text { As decisões tomadas até o momento suportam a estratégia de complementação } \\
\text { de portfolio elaborada. }\end{array}$ \\
\hline
\end{tabular}

$5 \quad$ Seus comentários, se algum relevante, em relação às questões acima:

\begin{tabular}{|c|l|}
\hline $\mathbf{6}$ & Estou otimista em relação à: \\
\hline $6 \mathrm{~A}$ & habilidade da empresa para gerar novos produtos com alta performance. \\
\hline 6B & habilidade da empresa para gerar produtos sob demanda. \\
\hline 6C & $\begin{array}{l}\text { habilidade da empresa para introduzir a estratégia de complementação de } \\
\text { portfolio com a diferenciação requerida. }\end{array}$ \\
\hline 6D & habilidade da empresa para produzir e entregar os produtos no tempo adequado. \\
\hline
\end{tabular}




\begin{tabular}{|c|c|}
\hline 7 & Seus comentários, se algum relevante, em relação às questões acima: \\
\hline 8 & Tenho confiança na: \\
\hline $8 \mathrm{~A}$ & capacidade de implementação da estratégia do time de liderança da empresa. \\
\hline $8 \mathrm{~B}$ & $\begin{array}{l}\text { capacidade de implementação da estratégia do time de liderança da minha } \\
\text { função. }\end{array}$ \\
\hline $8 \mathrm{C}$ & capacidade de implementação da estratégia de todo o meu time funcional. \\
\hline $8 \mathrm{D}$ & na minha capacidade de implementação da estratégia. \\
\hline
\end{tabular}

\begin{tabular}{|c|l|}
\hline $\mathbf{1 0}$ & Baseado na minha experiência, acredito que: \\
\hline $10 \mathrm{~A}$ & O processo de integração do negócio tem sido justo e objetivo. \\
\hline 10B & O processo de integração de recursos humanos tem sido justo e objetivo. \\
\hline 10C & As decisões-chave relacionadas à integração foram tomadas no tempo adequado. \\
\hline $10 \mathrm{D}$ & $\begin{array}{l}\text { As principais decisões relacionadas à gestão de recursos humanos foram } \\
\text { tomadas no momento correto. }\end{array}$ \\
\hline $10 \mathrm{E}$ & $\begin{array}{l}\text { As decisões-chave relacionadas à localização do site de desenvolvimento de } \\
\text { produtos foram tomadas no tempo adequado. }\end{array}$ \\
\hline $10 \mathrm{~F}$ & $\begin{array}{l}\text { As decisões-chave relacionadas à localização do site de manufatura da empresa } \\
\text { foram tomadas no tempo adequado. }\end{array}$ \\
\hline $10 \mathrm{G}$ & $\begin{array}{l}\text { As decisões-chave relacionadas à localização do escritório central da empresa } \\
\text { foram tomadas no tempo adequado. }\end{array}$ \\
\hline $10 \mathrm{H}$ & Soube da minha situação profissional na empresa o mais breve possível. \\
\hline
\end{tabular}

\begin{tabular}{|c|l|}
\hline $\mathbf{1 1}$ & Seus comentários, se algum relevante, em relação às questões acima: \\
\hline $\mathbf{1 2}$ & Sua opinião em relação à comunicação: \\
\hline 12A & A comunicação tem sido bastante aberta. \\
\hline 12B & A comunicação tem sido passada no momento correto. \\
\hline $12 \mathrm{C}$ & A quantidade de comunicação recebida foi suficiente. \\
\hline $12 \mathrm{D}$ & $\begin{array}{l}\text { As comunicações a respeito de mudanças na organização atenderam as minhas } \\
\text { necessidades. }\end{array}$ \\
\hline $12 \mathrm{E}$ & $\begin{array}{l}\text { Meu gestor manteve-me informado a respeito dos planos de integração. que me } \\
\text { afetariam. me. }\end{array}$ \\
\hline $12 \mathrm{~F}$ & A comunicação e coordenação entre times de integração foi efetiva. \\
\hline
\end{tabular}

13 Seus comentários, se algum relevante, em relação às questões acima: 


\begin{tabular}{|c|l|}
\hline 14 & O processo de ocupação das posições na nova organização: \\
\hline 14A & $\begin{array}{l}\text { As informações relacionadas às posições que ficariam disponíveis na minha area } \\
\text { foram bem organizadas e gerenciadas de maneira apropriada. }\end{array}$ \\
\hline 14B & $\begin{array}{l}\text { O processo de aplicação para novas posições foi bem organizado e gerenciado } \\
\text { apropriadamente. }\end{array}$ \\
\hline 14C & $\begin{array}{l}\text { O processo de entrevistas para as novas posições foi bem organizado e } \\
\text { gerenciado de maneira apropriada. }\end{array}$ \\
\hline $14 \mathrm{D}$ & $\begin{array}{l}\text { Eu mudei de posição durante a integração e os termos aplicados foram } \\
\text { apropriados. }\end{array}$ \\
\hline $14 \mathrm{E}$ & $\begin{array}{l}\text { Eu fui realocado para um novo site da organização durante a integração e os } \\
\text { termos foram satisfatórios }\end{array}$ \\
\hline $14 \mathrm{~F}$ & $\begin{array}{l}\text { Tive respostas adequadas para as perguntas relacionadas à gestão de } \\
\text { remuneração. }\end{array}$ \\
\hline $14 \mathrm{G}$ & $\begin{array}{l}\text { A implementação da folha de pagamento e administração de benefícios foi bem } \\
\text { sucedida. }\end{array}$ \\
\hline
\end{tabular}

\begin{tabular}{|c|c|}
\hline 15 & Seus comentários, se algum relevante, em relação às questões acima: \\
\hline 16 & Coordenação e gerenciamento da integração: \\
\hline $16 \mathrm{~A}$ & $\begin{array}{l}\text { Eu soube quem pertence ao meu time de integração e o seu conjunto de } \\
\text { atribuições e responsabilidades. }\end{array}$ \\
\hline 16B & O time de integração relacionado à minha função foi efetivo e comunicativo \\
\hline 16C & $\begin{array}{l}\text { O time de integração relacionado à minha função teve os recursos necessários } \\
\text { para implementar com o sucesso a integração. }\end{array}$ \\
\hline $16 \mathrm{D}$ & $\begin{array}{l}\text { Há consistente planejamento para as atividades de integração previstas para os } \\
\text { próximos meses. }\end{array}$ \\
\hline $16 \mathrm{E}$ & $\begin{array}{l}\text { O tratamento dispensado aos profissionais que não receberam posições na nova } \\
\text { organização foi justo e respeitoso. }\end{array}$ \\
\hline $16 \mathrm{~F}$ & $\begin{array}{l}\text { Conheço a nova estrutura organizacional, assim como as atribuições e } \\
\text { responsabilidades das pessoas que atuam na minha área. }\end{array}$ \\
\hline 16G & Conheço as metas de integração para a sinergia de custos. \\
\hline $16 \mathrm{H}$ & $\begin{array}{l}\text { Considero as metas de sinergia de custos consistentes e passíveis de serem } \\
\text { alcançadas. }\end{array}$ \\
\hline $16 \mathrm{I}$ & Meu gestor apóia o processo de integração. \\
\hline
\end{tabular}

17 Seus comentários, se algum relevante, em relação às questões acima: 


\begin{tabular}{|c|l|}
\hline $\mathbf{1 8}$ & Comentários sobre a sua opinião e dos seus pares: \\
\hline $18 \mathrm{~A}$ & Até o momento a integração tem sido um sucesso. \\
\hline $18 \mathrm{~B}$ & Os meus pares estão satisfeitos com a integração até o momento. \\
\hline $18 \mathrm{C}$ & $\begin{array}{l}\text { Ações relacionadas à retenção de profissionais-chave estão sendo implementadas } \\
\text { durante a integração. }\end{array}$ \\
\hline $18 \mathrm{D}$ & A empresa continuará a reter profissionais-chave nos próximos seis meses. \\
\hline $18 \mathrm{E}$ & $\begin{array}{l}\text { A carga de trabalho durante o processo de integração foi passível de } \\
\text { gerenciamento. }\end{array}$ \\
\hline $18 \mathrm{~F}$ & Estou começando a me identificar com a minha função na nova organização. \\
\hline $18 \mathrm{G}$ & $\begin{array}{l}\text { Meus pares estão começando a se identificar com a suas funções na nova } \\
\text { organização. }\end{array}$ \\
\hline $18 \mathrm{H}$ & $\begin{array}{l}\text { Os empregados têm neste momento energia suficiente para tornar a integração } \\
\text { um sucesso. }\end{array}$ \\
\hline
\end{tabular}

19 Seus comentários, se algum relevante, em relação às questões acima:

\begin{tabular}{|c|l|}
\hline $\mathbf{2 0}$ & Sua compreensão das metas e diretrizes: \\
\hline $20 \mathrm{~A}$ & $\begin{array}{l}\text { Conheço as expectativas em relação à minha atuação para a implementação da } \\
\text { estratégia. }\end{array}$ \\
\hline $20 \mathrm{~B}$ & As expectativas em relação à minha atuação são consistentes. \\
\hline $20 \mathrm{C}$ & Eu compreendo as metas operacionais da minha função. \\
\hline $20 \mathrm{D}$ & Eu compreendo as metas financeiras da minha função. \\
\hline $20 \mathrm{E}$ & $\begin{array}{l}\text { Meu gestor tem sido claro quanto às mudanças decorrentes da integração e as } \\
\text { suas causas. }\end{array}$ \\
\hline
\end{tabular}

$\mathbf{2 1}$ Seus comentários, se algum relevante, em relação às questões acima:

\begin{tabular}{|c|l|}
\hline 22 & Questões adicionais: \\
\hline 22A & Sabemos qual é a visão de futuro e quais são os caminhos para atingí-la. \\
\hline 22B & Estamos encontrando novos e melhores caminhos para fazer as coisas. \\
\hline 22C & Estou confiante em relação à nossa competitividade na indústria. \\
\hline 22D & Acredito que pertenço a um time vencedor. \\
\hline $22 \mathrm{E}$ & Estamos nos tornando mais inovadores. \\
\hline $22 \mathrm{~F}$ & $\begin{array}{l}\text { Os processos e procedimentos estão evoluindo de acordo com as estratégias } \\
\text { estabelecidas. }\end{array}$ \\
\hline
\end{tabular}




\section{APÊNDICE D: DADOS DA ANÁLISE DE CONSISTÊNCIA}

Visão de futuro

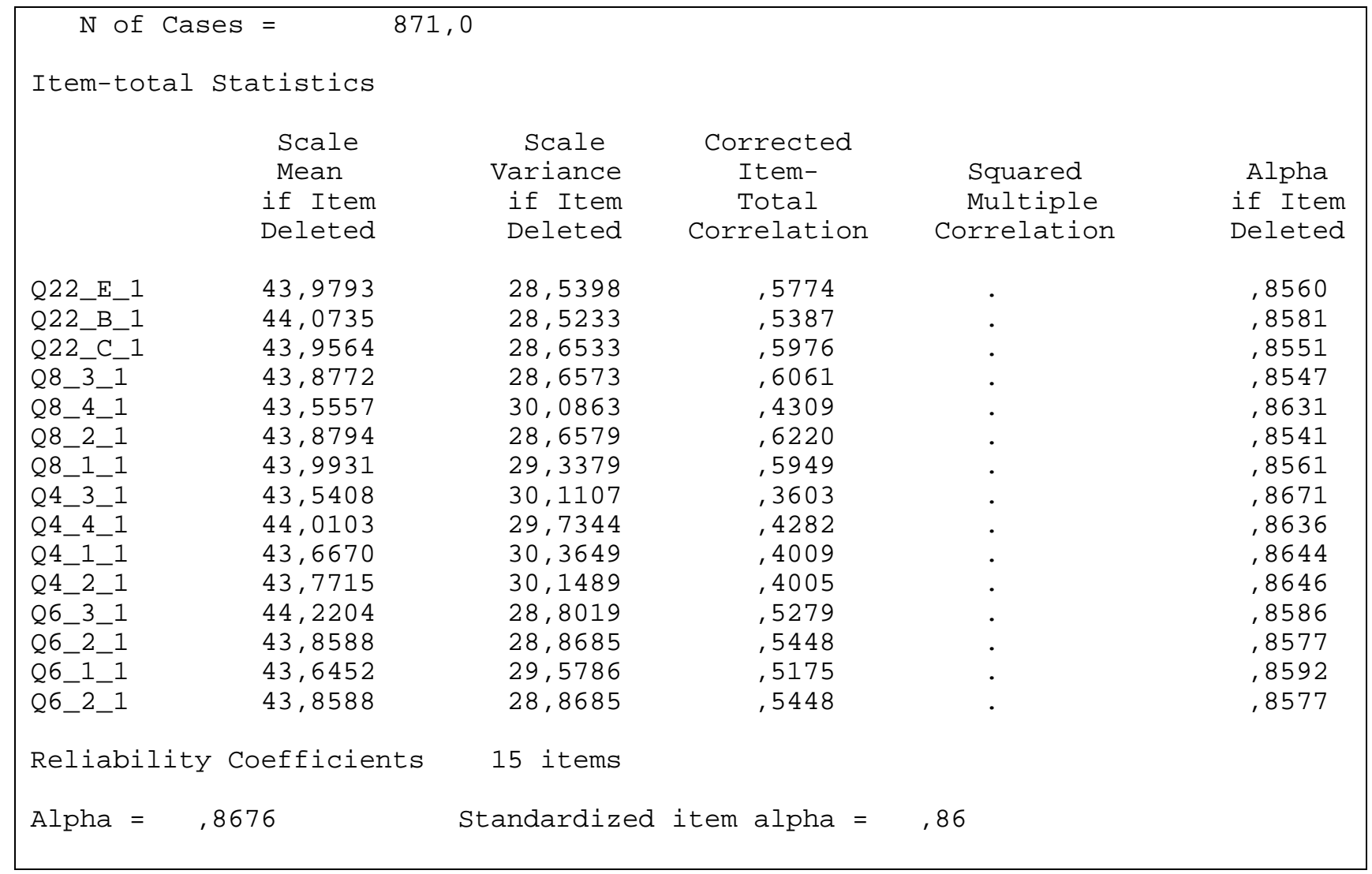

\section{Comunicação}

\begin{tabular}{|c|c|c|c|c|c|}
\hline \multicolumn{6}{|c|}{$\mathrm{N}$ of Cases $=871,0$} \\
\hline \multicolumn{6}{|c|}{ Item-total Statistics } \\
\hline & Scale & Scale & Corrected & & \\
\hline & Mean & Variance & Item- & Squared & Alpha \\
\hline & if Item & if Item & Total & Multiple & if Item \\
\hline & Deleted & Deleted & Correlation & Correlation & Deleted \\
\hline Q12_1_1 & 14,4168 & 6,2456 &, 7639 &, 6465 &, 8151 \\
\hline Q12_2_1 & 14,5144 & 6,0087 & 7858 & 6869 & 8098 \\
\hline Q12_3_1 & 14,4719 & 6,1897 & 7560 & 6116 & 8163 \\
\hline Q12_4_1 & 14,5385 & 6,3775 & 6998 & 4943 & 8274 \\
\hline Q12_5_1 & 14,3708 & 6,5462 & 5613 & 3273 & 8567 \\
\hline Q12_6_1 & 14,3812 & 8,4178 &, 3577 &, 1406 &, 8783 \\
\hline Reliabilit & y Coefficients & 6 items & & & \\
\hline Alpha = & 8601 & Standardized & item alpha $=$ &, 8547 & \\
\hline
\end{tabular}


Processo de integração

\begin{tabular}{|c|c|c|c|c|c|}
\hline \multicolumn{6}{|c|}{$\mathrm{N}$ of Cases $=871,0$} \\
\hline \multicolumn{6}{|c|}{ Item-total statistics } \\
\hline & Scale & Scale & Corrected & & \\
\hline & Mean & Variance & Item- & Squared & Alpha \\
\hline & if Item & if Item & Total & Multiple & if Item \\
\hline & Deleted & Deleted & Correlation & Correlation & Deleted \\
\hline Q10_5_1 & 35,8301 & 25,1550 &, 5297 & , 3889 &, 8533 \\
\hline Q10_6_1 & 35,8783 & 25,3185 & 4672 & 3045 & 8561 \\
\hline Q10_4_1 & 36,0597 & 23,3941 &, 6518 &, 5462 &, 8453 \\
\hline Q10_3_1 & 36,0264 & 23,2533 & 6669 &, 5713 & 8443 \\
\hline Q10_7_1 & 36,0149 & 24,6354 & 4269 & 2455 & 8597 \\
\hline Q10_1_1 & 35,7842 & 24,7373 &, 5481 &, 3699 &, 8520 \\
\hline Q18_5_1 & 36,1584 & 24,1565 & 5120 &, 3892 &, 8542 \\
\hline Q22_F_1 & 36,2308 & 23,9961 & 4899 & 3720 & 8562 \\
\hline Q16_7_1 & 35,9736 & 25,3177 &, 3976 &, 2925 &, 8602 \\
\hline Q16_8_1 & 35,7865 & 26,2095 & 4016 & 2665 &, 8593 \\
\hline Q16_1_1 & 35,9472 & 24,7696 & 4967 & 4150 & 8546 \\
\hline Q16_2_1 & 35,8749 & 24,6177 & 5996 &, 5318 &, 8496 \\
\hline Q16_3_1 & 35,8129 & 24,9431 &, 5842 & , 4550 & , 8508 \\
\hline Q16_4_1 & 35,9059 & 25,2141 &, 5044 &, 3361 &, 8544 \\
\hline Reliabi & y Coefficients & 14 items & & & \\
\hline Alpha $=$ & 8627 & Standardized & item alpha $=$ &, 8656 & \\
\hline
\end{tabular}

Gestão de recursos humanos

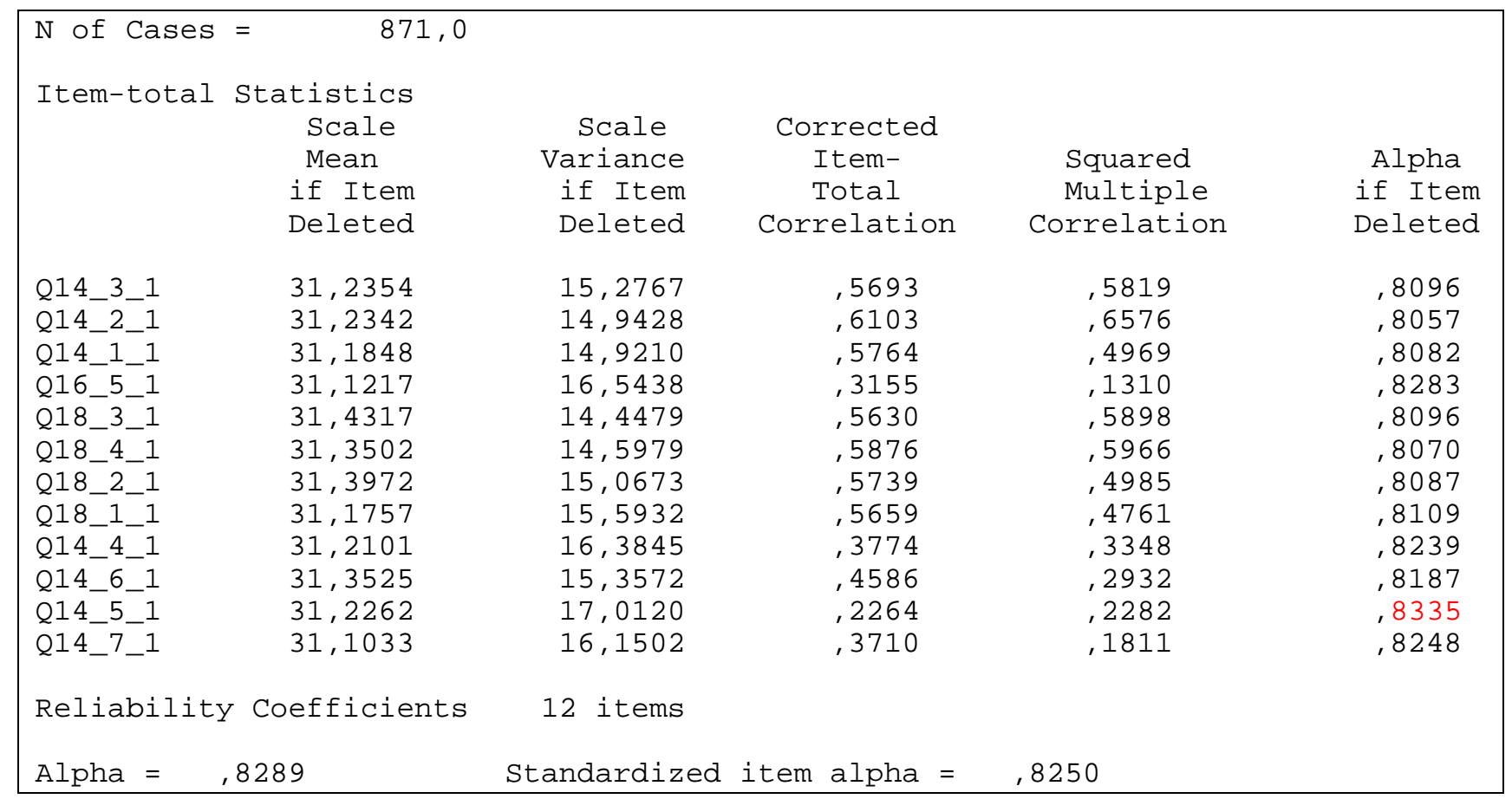


Clareza de expectativas

\begin{tabular}{|c|c|c|c|c|c|}
\hline \multicolumn{6}{|c|}{$\mathrm{N}$ of Cases $=871,0$} \\
\hline \multicolumn{6}{|c|}{ Item-total statistics } \\
\hline & Scale & Scale & Corrected & & \\
\hline & Mean & Variance & Item- & Squared & Alpha \\
\hline & if Item & if Item & Total & Multiple & if Item \\
\hline & Deleted & Deleted & Correlation & Correlation & Deleted \\
\hline Q20_1_1 & 38,7933 & 31,4147 &, 7182 &, 6164 &, 9031 \\
\hline Q20_3_1 & 38,7922 & 32,0660 & 7180 & 6256 & 9037 \\
\hline Q20_2_1 & 38,8530 & 32,8565 & 6053 & 4295 & 9075 \\
\hline Q18_6_1 & 38,8519 & 32,1884 & 6876 &, 6098 & 9047 \\
\hline Q20_4_1 & 38,9667 & 32,2000 & 5970 & 4836 & 9077 \\
\hline Q20_5_1 & 39,0276 & 30,6406 & 7139 &, 5477 & 9031 \\
\hline Q18_7_1 & 38,9127 & 32,8567 & 6442 &, 5804 &, 9065 \\
\hline Q16_9_1 & 38,6315 & 33,4629 & 5409 & 3320 & 9096 \\
\hline Q16_6_1 & 39,0080 & 32,1344 &, 6024 &, 3770 &, 9075 \\
\hline Q12_5_1 & 38,8840 & 31,5992 &, 5672 & 4043 & 9097 \\
\hline Q22_D_1 & 38,5786 & 32,4004 &, 6105 & 4525 & 9072 \\
\hline Q22_A_1 & 38,8657 & 31,8842 &, 6504 &, 4761 &, 9057 \\
\hline Q10_8_1 & 38,9001 & 31,5636 & 5520 &, 3445 &, 9106 \\
\hline Q18_8_1 & $39,0 \odot 92$ & 32,2574 &, 6079 &, 4419 &, 9073 \\
\hline Reliabi. & y Coefficients & 14 items & & & \\
\hline Alpha $=$ & 9128 & Standardized & item alpha $=$ &, 9156 & \\
\hline
\end{tabular}




\section{APÊNDICE E: RESULTADOS DA ANÁLISE FATORIAL}

Rotated Component Matrix Component

\begin{tabular}{|c|c|c|c|c|c|c|c|c|c|c|c|c|c|}
\hline & 1 & 2 & 3 & 4 & 5 & 6 & 7 & 8 & 9 & 10 & 11 & 12 & 13 \\
\hline $20 \mathrm{~A}$ & 0.780 & 0.143 & 0.044 & 0.039 & 0.121 & 0.048 & 0.148 & 0.148 & 0.141 & 0.052 & 0.076 & 0.057 & 0.040 \\
\hline $20 \mathrm{C}$ & 0.743 & 0.156 & 0.115 & 0.071 & 0.099 & 0.069 & 0.157 & 0.101 & 0.132 & 0.060 & 0.071 & 0.064 & 0.136 \\
\hline $20 \mathrm{D}$ & 0.642 & 0.125 & 0.060 & 0.179 & 0.166 & 0.015 & 0.042 & 0.071 & -0.009 & 0.021 & 0.006 & 0.008 & 0.393 \\
\hline $20 \mathrm{E}$ & 0.642 & 0.208 & 0.176 & 0.118 & 0.202 & 0.165 & 0.030 & 0.232 & 0.030 & 0.093 & -0.059 & 0.101 & 0.093 \\
\hline $20 \mathrm{~B}$ & 0.607 & 0.075 & 0.169 & 0.146 & 0.083 & 0.113 & 0.184 & -0.054 & 0.031 & 0.164 & 0.206 & 0.096 & 0.072 \\
\hline $18 \mathrm{~F}$ & 0.603 & 0.108 & 0.083 & 0.116 & 0.218 & 0.203 & 0.092 & 0.141 & 0.178 & 0.014 & 0.343 & 0.025 & -0.050 \\
\hline $18 \mathrm{G}$ & 0.522 & 0.116 & 0.190 & 0.053 & 0.181 & 0.169 & 0.113 & 0.151 & 0.107 & -0.014 & 0.452 & -0.001 & 0.005 \\
\hline $16 \mathrm{~F}$ & 0.449 & 0.177 & 0.125 & 0.008 & 0.080 & 0.158 & 0.165 & 0.429 & 0.053 & 0.003 & 0.040 & 0.068 & 0.225 \\
\hline $16 \mathrm{I}$ & 0.425 & 0.162 & 0.135 & 0.083 & 0.150 & 0.166 & 0.255 & 0.181 & 0.210 & -0.011 & -0.061 & 0.103 & -0.156 \\
\hline $12 \mathrm{~B}$ & 0.175 & 0.786 & 0.029 & 0.186 & 0.154 & 0.159 & 0.113 & 0.103 & 0.087 & 0.066 & 0.042 & 0.008 & 0.077 \\
\hline $12 \mathrm{C}$ & 0.135 & 0.783 & 0.033 & 0.135 & 0.144 & 0.128 & 0.124 & 0.102 & 0.120 & 0.052 & 0.089 & 0.002 & 0.080 \\
\hline $12 \mathrm{~A}$ & 0.172 & 0.761 & 0.085 & 0.182 & 0.113 & 0.186 & 0.103 & 0.087 & 0.128 & 0.046 & -0.039 & 0.006 & 0.043 \\
\hline $12 \mathrm{D}$ & 0.223 & 0.651 & 0.133 & 0.165 & 0.032 & 0.159 & 0.111 & 0.182 & 0.048 & 0.140 & 0.125 & 0.033 & 0.111 \\
\hline $12 \mathrm{~F}$ & 0.050 & 0.462 & 0.141 & 0.138 & -0.014 & -0.094 & 0.019 & 0.095 & 0.010 & -0.043 & 0.231 & 0.243 & -0.011 \\
\hline $12 \mathrm{E}$ & 0.378 & 0.449 & 0.146 & 0.119 & 0.039 & 0.228 & 0.141 & 0.318 & 0.047 & 0.094 & -0.162 & 0.122 & -0.060 \\
\hline $18 \mathrm{D}$ & 0.231 & 0.064 & 0.729 & 0.092 & 0.212 & 0.154 & 0.066 & 0.127 & -0.057 & 0.071 & 0.133 & 0.094 & 0.036 \\
\hline $18 \mathrm{C}$ & 0.235 & 0.093 & 0.697 & 0.187 & 0.192 & 0.161 & 0.086 & 0.084 & -0.076 & 0.053 & 0.037 & 0.036 & 0.120 \\
\hline $18 \mathrm{~B}$ & 0.171 & 0.254 & 0.504 & 0.142 & 0.198 & 0.137 & 0.159 & 0.188 & 0.144 & -0.007 & 0.283 & 0.049 & 0.145 \\
\hline $18 \mathrm{~A}$ & 0.221 & 0.265 & 0.467 & 0.149 & 0.177 & 0.133 & 0.219 & 0.163 & 0.192 & -0.071 & 0.269 & 0.038 & 0.107 \\
\hline $6 \mathrm{C}$ & 0.086 & 0.004 & 0.440 & 0.180 & 0.119 & -0.054 & 0.149 & 0.142 & 0.293 & 0.405 & 0.012 & 0.112 & -0.064 \\
\hline $10 \mathrm{E}$ & 0.112 & 0.164 & 0.070 & 0.708 & 0.054 & 0.117 & 0.133 & 0.051 & 0.127 & -0.002 & 0.052 & 0.085 & 0.101 \\
\hline $10 \mathrm{~F}$ & 0.095 & 0.206 & 0.158 & 0.633 & 0.127 & -0.049 & 0.052 & 0.086 & 0.071 & 0.076 & -0.123 & 0.005 & 0.188 \\
\hline $10 \mathrm{D}$ & 0.124 & 0.316 & 0.101 & 0.579 & 0.071 & 0.288 & 0.096 & 0.118 & -0.011 & 0.154 & 0.196 & 0.072 & 0.100 \\
\hline $10 \mathrm{C}$ & 0.156 & 0.385 & 0.156 & 0.521 & 0.098 & 0.188 & 0.073 & 0.107 & 0.033 & 0.099 & 0.292 & .083 & 0.073 \\
\hline $10 G$ & 0.029 & 0.140 & -0.016 & 0.496 & -0.022 & 0.038 & 0.038 & 0.220 & -0.186 & 0.444 & 0.202 & 0.104 & -0.051 \\
\hline $10 \mathrm{~B}$ & & & & & & & & & & & & & 32 \\
\hline $10 \mathrm{H}$ & 0.329 & 0.281 & 0.032 & 0.412 & 0.123 & 0.311 & 0.152 & 0.184 & 0.091 & -0.046 & -0.037 & 0.144 & 0.009 \\
\hline $10 \mathrm{~A}$ & 0.164 & 0.330 & 0.236 & 0.404 & 0.165 & 0.142 & 0.175 & 0.101 & 0.200 & -0.088 & 0.257 & 0.089 & -0.075 \\
\hline $22 \mathrm{E}$ & 0.168 & 0.153 & 0.150 & 0.117 & 0.722 & 0.075 & 0.119 & 0.116 & 0.043 & 0.185 & 0.088 & 0.085 & 0.088 \\
\hline 22B & 0.247 & 0.124 & 0.183 & 0.123 & 0.717 & 0.085 & 0.188 & 0.139 & 0.021 & 0.025 & 0.106 & 0.083 & 0.065 \\
\hline $22 \mathrm{C}$ & 0.117 & 0.013 & 0.229 & 0.102 & 0.604 & 0.067 & 0.169 & -0.012 & 0.119 & 0.379 & -0.004 & 0.122 & 0.040 \\
\hline $22 \mathrm{D}$ & 0.335 & 0.146 & 0.118 & 0.094 & 0.589 & 0.142 & 0.215 & 0.054 & 0.140 & 0.227 & 0.082 & 0.151 & -0.009 \\
\hline $22 \mathrm{~A}$ & 0.362 & 0.198 & 0.134 & 0.064 & 0.510 & 0.044 & 0.287 & 0.267 & 0.058 & 0.107 & 0.094 & 0.057 & 0.100 \\
\hline 14B & 0.143 & 0.213 & 0.103 & 0.115 & 0.080 & & 0.041 & 0.090 & 0.048 & 0.098 & 0.129 & 0.140 & 0.085 \\
\hline $14 \mathrm{C}$ & 0.162 & 0.112 & 0.087 & 0.110 & 0.062 & 0.770 & 0.070 & 0.110 & 0.010 & 0.102 & 0.080 & 0.141 & 0.069 \\
\hline $14 \mathrm{~A}$ & 0.183 & 0.321 & 0.064 & 0.128 & 0.089 & 0.691 & 0.085 & 0.153 & 0.086 & 0.067 & 0.065 & 0.105 & 0.052 \\
\hline $16 \mathrm{E}$ & 0.029 & -0.136 & 0.199 & 0.362 & 0.145 & 0.389 & 0.040 & 0.140 & 0.176 & 0.013 & -0.061 & -0.070 & 0.019 \\
\hline $8 \mathrm{~A}$ & 0.231 & 0.143 & 0.190 & 0.087 & 0.198 & 0.144 & 0.746 & 0.118 & 0.047 & 0.154 & -0.012 & 0.048 & 0.018 \\
\hline $8 C$ & 0.191 & 0.112 & 0.175 & 0.091 & 0.191 & 0.129 & 0.733 & 0.068 & 0.061 & 0.167 & 0.077 & 0.035 & 0.115 \\
\hline 8D & 0.192 & 0.083 & -0.098 & 0.084 & 0.143 & -0.016 & 0.656 & 0.060 & 0.103 & 0.077 & 0.210 & 0.063 & -0.019 \\
\hline $8 B$ & 0.102 & 0.203 & 0.285 & 0.237 & 0.156 & 0.019 & 0.591 & 0.126 & 0.165 & 0.121 & 0.034 & 0.044 & 0.056 \\
\hline $16 \mathrm{~B}$ & 0.202 & 0.218 & 0.074 & 0.163 & 0.150 & 0.167 & 0.109 & 0.726 & 0.023 & 0.059 & 0.082 & 0.073 & 0.080 \\
\hline $16 \mathrm{~A}$ & 0.216 & 0.138 & 0.160 & 0.204 & 0.077 & & -0.026 & & & -0.017 & -0.070 & 0.017 & 0.091 \\
\hline $16 \mathrm{C}$ & 0.140 & 0.149 & 0.109 & 0.122 & 0.116 & 0.112 & 0.206 & 0.603 & 0.012 & 0.092 & 0.347 & 0.099 & 0.101 \\
\hline $16 \mathrm{D}$ & 0.124 & 0.195 & 0.176 & 0.013 & 0.142 & 0.053 & 0.209 & 0.421 & 0.084 & 0.071 & 0.379 & 0.095 & 0.175 \\
\hline $4 \mathrm{~A}$ & 0.224 & 0.141 & -0.036 & 0.036 & 0.088 & 0.123 & 0.141 & 0.018 & 0.740 & -0.016 & -0.066 & 0.039 & 0.087 \\
\hline $4 B$ & 0.206 & 0.130 & -0.106 & 0.060 & 0.104 & 0.092 & 0.052 & 0.075 & 0.694 & 0.110 & -0.038 & 0.005 & 0.275 \\
\hline $4 C$ & 0.042 & 0.027 & 0.140 & 0.081 & -0.009 & 0.004 & 0.052 & 0.058 & 0.580 & 0.237 & 0.113 & 0.050 & -0.173 \\
\hline $4 \mathrm{D}$ & -0.024 & 0.170 & 0.425 & 0.147 & 0.053 & -0.055 & 0.084 & 0.100 & 0.480 & 0.149 & 0.119 & 0.113 & -0.077 \\
\hline $6 B$ & 0.077 & 0.034 & 0.078 & 0.038 & 0.195 & 0.111 & 0.058 & 0.020 & 0.061 & 0.772 & 0.074 & 0.039 & -0.009 \\
\hline $6 \mathrm{~A}$ & 0.154 & 0.116 & -0.047 & 0.040 & 0.138 & 0.111 & 0.206 & -0.006 & 0.213 & 0.659 & -0.019 & 0.004 & 0.006 \\
\hline $6 \mathrm{D}$ & -0.072 & 0.037 & 0.332 & -0.012 & 0.244 & 0.004 & 0.206 & 0.044 & 0.207 & 0.433 & -0.010 & 0.048 & 0.171 \\
\hline
\end{tabular}




\begin{tabular}{|l|cccccccccccc|c|c|c|}
$18 \mathrm{E}$ & 0.215 & 0.144 & 0.280 & 0.191 & 0.012 & 0.142 & 0.084 & 0.005 & -0.160 & 0.176 & 0.446 & 0.130 & 0.190 \\
$22 \mathrm{~F}$ & 0.188 & 0.100 & 0.207 & 0.087 & 0.372 & 0.133 & 0.203 & 0.174 & 0.038 & 0.036 & 0.431 & 0.084 & 0.139 \\
$18 \mathrm{H}$ & 0.351 & 0.156 & 0.382 & 0.112 & 0.203 & 0.122 & 0.157 & 0.089 & 0.029 & 0.178 & 0.427 & 0.074 & 0.196 \\
\hline $14 \mathrm{D}$ & 0.082 & 0.005 & 0.024 & 0.018 & 0.112 & 0.135 & 0.043 & 0.041 & 0.065 & 0.035 & 0.106 & 0.780 & 0.048 \\
$14 \mathrm{E}$ & -0.020 & -0.015 & -0.023 & 0.075 & 0.112 & -0.015 & -0.059 & 0.045 & 0.054 & 0.029 & 0.115 & 0.742 & -0.052 \\
$14 \mathrm{~F}$ & 0.188 & 0.161 & 0.211 & -0.009 & -0.026 & 0.273 & 0.158 & 0.031 & -0.087 & 0.093 & -0.070 & 0.541 & 0.135 \\
$14 \mathrm{G}$ & 0.147 & 0.164 & 0.132 & 0.144 & 0.064 & 0.110 & 0.152 & 0.083 & 0.076 & 0.020 & -0.136 & 0.420 & 0.097 \\
\hline $16 \mathrm{H}$ & 0.075 & 0.063 & 0.078 & 0.186 & 0.098 & 0.081 & 0.069 & 0.073 & 0.047 & -0.011 & 0.228 & 0.055 & 0.687 \\
$16 \mathrm{G}$ & 0.289 & 0.113 & 0.115 & 0.082 & 0.053 & 0.103 & 0.022 & 0.229 & 0.035 & 0.019 & -0.038 & 0.071 & 0.674 \\
\hline
\end{tabular}

Extraction Method: Principal Component Analysis.

Rotation Method: Varimax with Kaiser Normalization. 


\section{PARTE V: REFERÊNCIAS BIBLIOGRÁFICAS}

Argyris, C. Why individuals and organizations have difficulty in double-loop learning, in Argyris, C., On organizational learning, Cambridge: Blackwell Publishers, 1992.

Barros, B. T. Fusões e aquisições no Brasil: entendendo as razões dos sucessos e fracassos, São Paulo: Atlas, 2003.

Bazerman, M. H. Processo decisório, São Paulo: Elsevier Editora, 2004.

Bendassolli, P. F. O fetiche da mudança in Revista de Administração de Empresas da Fundação Getúlio Vargas, RAE Executivo, agosto - outubro, São Paulo, 2003.

Beer, M \& Spector, B \& Eisenstat, R. A. Why change programs don’t produce change in Harvard Business Review, January - February, 1990.

Blackburn, S. The Oxford dictionary of philosophy, Oxford: Oxford University Press, 1994.

Bower, J. L., Not all mergers are alike - and that matters in Harvard Business Review, march, 2001.

Brandenburger, A. M. \& Nalebuff, B. J. Coopetition, New York: Doubleday, 1996.

Chandler, A. D., Strategy and structure: chapters in the history of industrial enterprise, Cambridge, The Massachussets Institute of Technology Press, 1962.

Coase, R.H. The firm, the market and the law, The University of Chicago Press, 1988.

Cohen, S. G. A nova organização por equipe e o trabalho de equipe, in Galbraith, J. R \& Lawler III, E. E. Organizando para competir no futuro, São Paulo, Makron Books, 1995.

Collins, J. C. \& Porras, J. I. Built to last: successful habits of visionary companies, Harper Collins Publishers, New York, 1997. 
Cresswell, J. W., Research design: qualitative, quantitative and mixed method approaches, London, Sage Publications, 2003.

Demsetz, H. The economics of the business enterprise - seven critical commentaries, Cambridge University Press, 1995.

Dicken, P. Globalshift: transforming the world economy, G.P. Editions, 2000.

Dutra, J. S. Gestão de pessoas: modelo, processos, tendências e perspectivas, São Paulo: Atlas, 2002.

Competências: conceitos e instrumentos para a gestão de pessoas na empresa moderna, São Paulo: Atlas, 2004.

Enriquez, J. \& Goldberg, R. A. Transforming life, transforming business: the life science revolution in Harvard Business Review, March - April, 2000.

Ernst, D. \& Havely, T. When to think alliance in What mergers miss, McKinsey Quarterly, USA, 2000.

Feldman, M. L. \& Spratt, M. F. Five frogs on a log: a CEO's guide to accelerating the transition in mergers, acquisitions and gut wrenching change, Boston: Harper Collins Publisher, 1999.

Fischer, R. M. Como estruturar um processo sustentado de mudança, IX T\&D RH Brasil, 1993, pp.01-11, mimeo.

Desafio à competência gerencial, texto utilizado para o módulo de Recursos Humanos do MBA Executivo FIA FEA USP, São Paulo, 1994, mimeo.

Mudança e transformação organizacional in As pessoas na organização, São Paulo: Editora Gente, 2002. 
Fleury, A.C. \& Fleury, M. T. L. Aprendizagem e inovação organizacional: as experiências do Japão, Coréia e Brasil, São Paulo: Atlas, 1995.

Estratégias empresariais e formação de competências: um quebra cabeça caleidoscópico da indústria brasileira, São Paulo: Atlas, 2000.

Fumento, M. Bio evolution: how biotechnology is changing the world, San Francisco: Encounter Books, 2003.

Galpin, T. J. \& Herndon, M. The complete guide to mergers and acquisitions: process tools to support M\&A integration at every level, San Francisco: Jossey Bass Publishers, 2000.

Gaughan, P. Mergers, acquisitions and corporate restructurings. New York: John Wiley and Sons, 1996.

Geisst, C. R. Wall Street, mergers and the making of modern America, New York: John Wiley \& Sons, 2003.

Goode, W. \& Hatt, P. Métodos de pesquisa social, São Paulo: Companhia das Letras, 1973.

Habeck, M. M., Kröger, F. \& Kräm, M. R. After the merger: seven rules for successful post merger integration, Pearson Education Limited, 2000.

Hacking, A. J., Economic aspects of biotechnology, Cambridge: Cambridge University Press, 1986.

Haspeslagh, P. C. \& Jemison, D. B. Managing acquisitions: creating value through corporate renewal, New York: The Free Press, 1991.

Héau, D, Mania de fusões in Barros, B. T. (organizadora) Fusões, aquisições e parcerias, São Paulo:Atlas, 2001. 
Hindery, L. The biggest game of all: the inside strategies, tactics and temperaments that make great dealmakers great, New York: The Free Press, 2003.

Kay, I. \& Shelton, M. The people problem in mergers in What mergers miss, McKinsey Quarterly, USA, 2000.

Kotler, P. \& Simon, F. A construção de biomarcas globais: levando a biotecnologia ao mercado, São Paulo: Bookman, 2004.

Lajoux, A. R. The art of M\&A integration: a guide to merging resources, processes and responsibilities, Mc Graw Hill, 2006.

Light, D. A. Who goes, who stays in Harvard business review on mergers and acquisitions, Boston: Harvard Business School Press, 2001.

Marks, M. L. \& Mirvis, P. H. Joining forces: making one plus one three in mergers, acquisitions and alliances, San Francisco: Jossey Bass, 1998.

Máttar, J. Filosofia e administração, São Paulo: Makron Books, 1997.

Mazzon, J. A. Análise do programa de alimentação do trabalhador sob o conceito de marketing social, Tese de doutorado apresentada à Faculdade de Economia e Administração da Universidade de São Paulo, São Paulo, 1981.

Meyer, C. \& Davis, S. It's alive: the coming convergence of information, biology and business, New York: Crown Business, 2003.

Miles, R. E. \& Snow, C. C. Organizational Strategy, Structure, and Process. New York: Mc Graw Hill Book Compay, 1978.

Mohrmann et allii., The phenomenon of large scale organizational change. In Mohrmann et allii., Large scale organizational change. San Francisco: Jossey Bass Publishers, 1991. 
Motta, P. R. Gestão contemporânea: a ciência e a arte de ser dirigente, São Paulo: Record, 1991.

Nevis, E.C., Dibella, A. J. \& Gould, J. M. Understanding organizations as learning systems in Sloan Management Review, Winter, 1995.

Nunnaly, J. Psycometric theory, New York: Mc Graw Hill, 1978.

Nutt, P. C. \& Backoff, R. W. Facilitating transformational change in The journal of applied behavioural science, Abi-Inform Global, 1997.

Pettigrew, A. The awakening giant: continuity and change in ICI, Oxford: Basil Blackwell, 1985.

Pettigrew, A. \& Whipp, R. Managing change for competitive success, Oxford: Blackwell Publishers, 1991.

Pritchet, P. After the merger: the authoritative guide to integration success, New York: McGraw-Hill, 1997.

Ratledge, C.; Sasson, A. \& Silva, E. J. Biotechnology:economic and social aspects, Cambridge: University Press, 1992.

Rossetti, J. P. Fusões e aquisições no Brasil: as razões e os impactos, in Barros, B. T. (organizadora), Fusões, aquisições e parcerias, São Paulo: Atlas, 2001.

Sá, L. G. Fusões e aquisições na indústria química do mercosul: impacto das desregulamentações e estratégia de crescimento, Tese de doutorado apresentada à Escola de Química da Universidade Federal do Rio de Janeiro, Rio de Janeiro, 2002.

Schein, E. H. Organizational culture and leadership. San Francisco: Jossey Bass Publishers, 1986. 
Selden, L. \& Colvin, G. Mergers and acquisitions needn't be a loser's game in Harvard Business Review, june, 2003

Senge, P., A quinta disciplina: arte, teoria e prática da organização de aprendizagem, São Paulo: Best Seller, 1990.

Senge, P. M. et alli. The fifth discipline - Fieldbook, New York: Currency Doubleday, 1994.

The dance of change: the challenges to sustaining momentum in learning organizations, New York: Currency Doubleday, 1999.

Sirower, M. The synergy trap: how companies lose the acquisition game, New York: Free Press/ Simon \& Schuster Inc., 1999.

Steiner, G. Strategic planning: what every manager must know. New York: The Free Press, 1979.

Strategor Politique générale de l'entreprise, Paris: Dunod, 1997.

Thiollent, M. Crítica metodológica e investigação social, São Paulo: Polis, 1980.

Wasserstein, B. Big deal: 2000 and beyond, Warner Books, 2000.

Williamsom, O. E. Markets and hierarchies: analysis and antitrust implications, New York: The Free Press, 1975.

Wongtschowski, P. Técnicas de redução de vulnerabilidade na indústria química, Tese de doutorado apresentada à Faculdade de Engenharia Química da Escola Politécnica da Universidade de São Paulo, 1998.

Indústria química: riscos e oportunidades, São Paulo: Editora Edgar Blucher, 2002. 
Yin, R. K. Case study research: designs and methods, London: Sage Publications, 1990.

Zweig, P. L., The case against mergers in Business Week, pp 122-130, October, 1995. 